Portland State University

PDXScholar

5-5-1995

\title{
Water Quality Model for South Slough, Coos Bay, Oregon
}

Holly Kay Juza

Portland State University

Follow this and additional works at: https://pdxscholar.library.pdx.edu/open_access_etds

Part of the Civil Engineering Commons Let us know how access to this document benefits you.

Recommended Citation

Juza, Holly Kay, "Water Quality Model for South Slough, Coos Bay, Oregon" (1995). Dissertations and Theses. Paper 5046.

https://doi.org/10.15760/etd.6922

This Thesis is brought to you for free and open access. It has been accepted for inclusion in Dissertations and Theses by an authorized administrator of PDXScholar. Please contact us if we can make this document more accessible: pdxscholar@pdx.edu. 


\section{THESIS APPROVAL}

The abstract and thesis of Holly Kay Juza for the Master of Science in Civil Engineering presented May 5, 1995, and accepted by the thesis committee and department.

COMMITTEE APPROVALS:

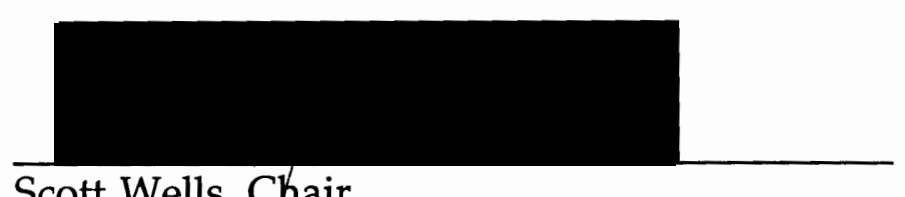

Scott Wells, Chair

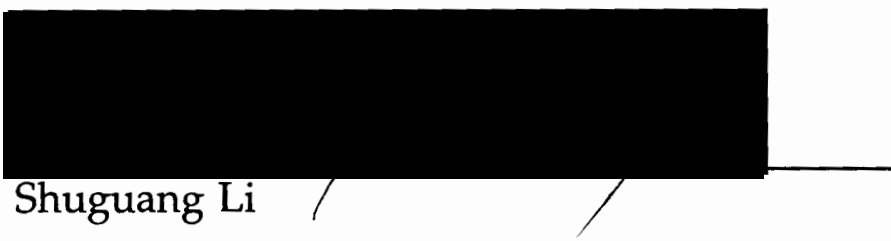

DEPARTMENT APPROVAL

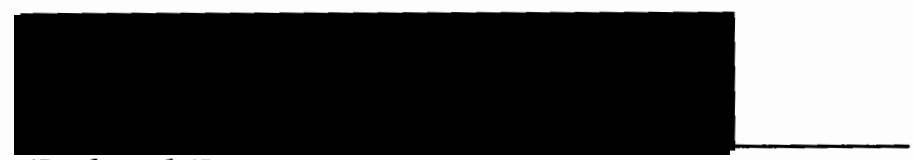

Richard Petersen

Representative of the Office of Graduate Studies
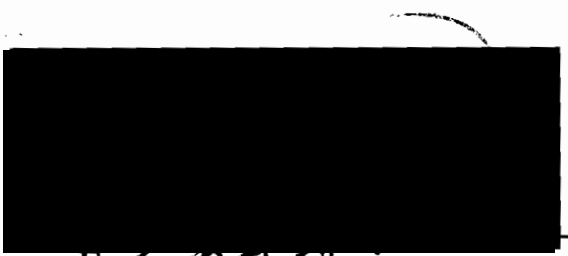

Frảnz'Rád, Chair

Department of Civil Engineering

\section{ACCEPTED FOR PORTLAND STATE UNIVERSITY BY THE LIBRARY}

by

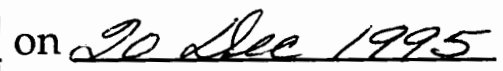




\begin{abstract}
An abstract of the thesis of Holly Kay Juza for the Master of Science in Civil Engineering presented May 5, 1995.
\end{abstract}

Title: Water Quality Model for South Slough, Coos Bay, Oregon.

The South Slough Estuary is located off Coos Bay along the southern coast of Oregon. It is divided into two channels that meet and continue to Coos Bay at the Charleston Harbor. There are six major contributing streams to South Slough. After rainfall events, the level of coliform bacteria in the slough increases because of stream bacteria loading. This is due to cattle grazing in the drainage areas, failed septic systems from private homes, and sewage sludge applied to the County landfill, which drains into the slough. The Oregon Health Division has enforced a Sanitation Management Plan for Commercial Shellfish Harvesting in South Slough that specifies closure of commercial shellfish harvesting for certain rainfall and flood events.

The purpose of this study is to analyze and improve the current understanding of the hydraulics and water quality of the South Slough Estuary. This was achieved by calibrating the South Slough using the water quality model CEQUAL-W2. It was calibrated for the following parameters water surface elevations, velocity, temperature and total dissolved solids. A management 
analysis was also done analyzing the transport of bacteria and a conservative tracer.

Model predictions for water surface elevations at one of the monitoring sites, Hinch Road Bridge, was significantly lower than measured elevations. There was an excellent correlation of velocity, and reasonable timing of peaks due to tidal effects. Model predictions for temperature and total dissolved solids match measured values well. To improve the accuracy of the model the following was recommended; install a raingage in the South Slough, measure temperature and constituent concentrations at inflow locations, survey the S4 current meter, new soundings performed of the Winchester Creek arm and at the Hinch Road Bridge gaging station, and investigate the possibility of an obstruction near the Hinch Road Bridge gaging station. 


\title{
WATER QUALITY MODEL \\ FOR \\ SOUTH SLOUGH, COOS BAY, OREGON
}

\author{
by
}

Holly Kay Juza

A thesis submitted in partial fulfillment of the requirements for the degree of

Master of Science
in
Civil Engineering

Portland State University

1995 


\section{TABLE OF CONTENTS}

Page \#

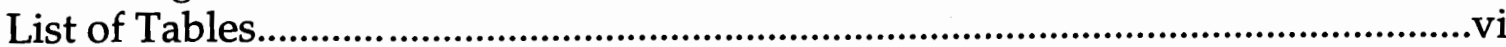

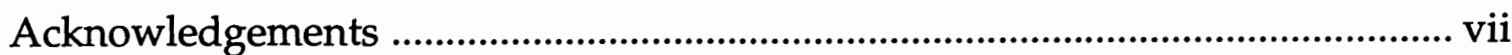

I INTRODUCTION

A Location and System Description.............................................................

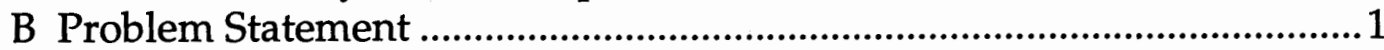

C Organization of Project................................................................................4

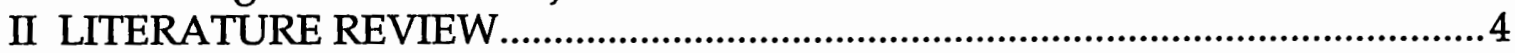

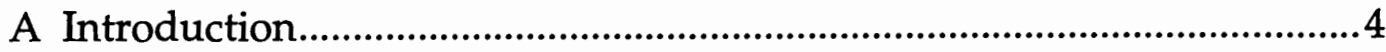

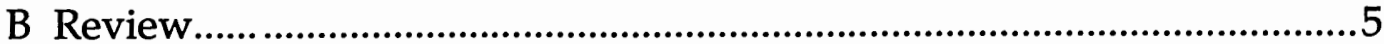

1. "Public Health Aspects of Shellfish from Polluted Waters" ........5

2. "Mathematical Model of Bacterial Contamination of the Morlaix Estuary".......................................................................6

3. "The Relationship Between Sediment and Fecal Coliform Levels in a Puget Sound Estuary" .........................................17

4. "The Shellfish Resource in a Polluted Tidal Inlet" .......................22

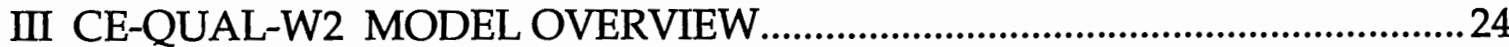

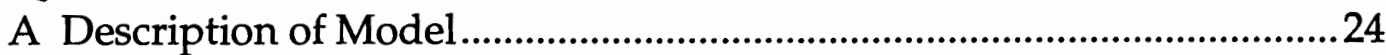

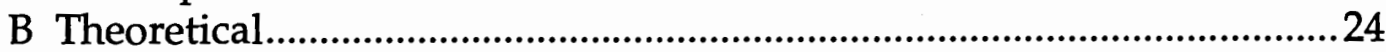

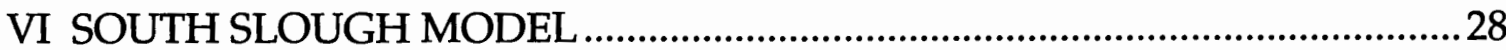

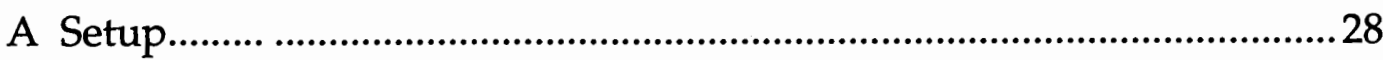

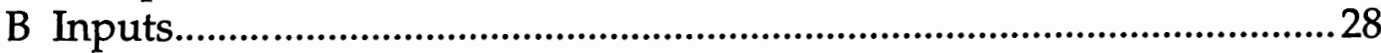

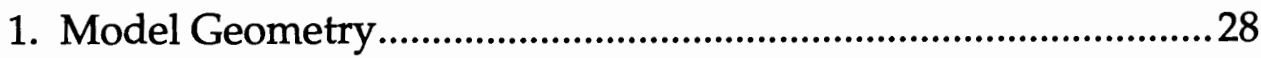

2. Meteorological Data .......................................................................39

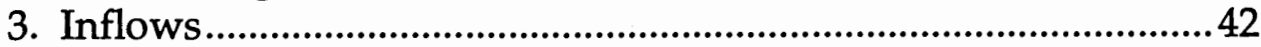

a. Flow Calculations, HEC-1 versus Rational Method .........43

b. Temperature and Concentrations ......................................57

4. Downstream Boundary Conditions............................................57

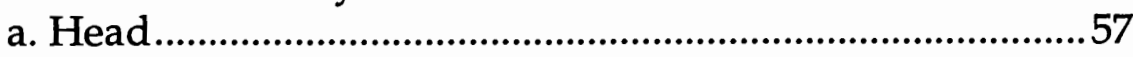

b. Temperature and Concentrations ......................................58

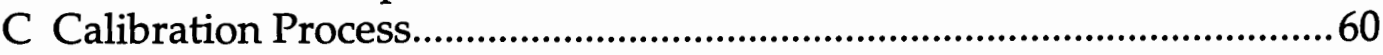

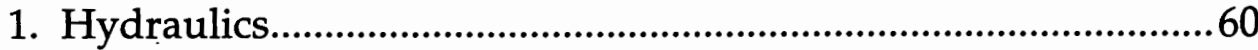

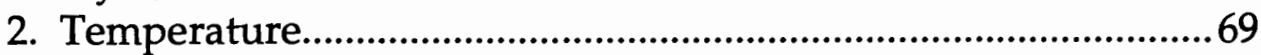

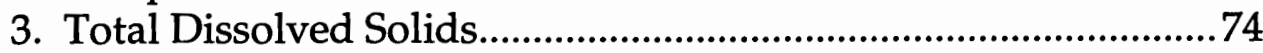

4. Model Calibration Summary .......................................................78

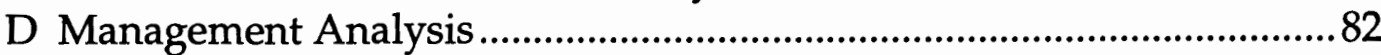

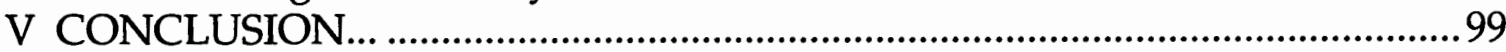

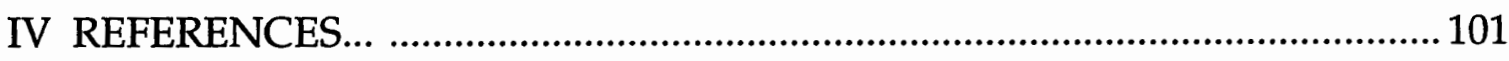

APPENDIX A Oregon Health Division Sanitation Management Plan

for Commercial Shellfish Harvesting in Joe Ney and South Slough ....... 102 APPENDIX B CE-QUAL-W2 Input files ............................................................. 107 


\section{LIST OF FIGURES}

FIGURE 1.1 South Slough Location Map ..........................................................................

FIGURE 1.2 South Slough Detailed Figure ..........................................................................

FIGURE 2.1 Morlaix Estuary Location and Sampling Points ..........................................

FIGURE 2.2 Long Term Current Behavior.......................................................................11

FIGURE 2.3 Salinity Results ........................................................................................12

FIGURE 2.4 Transit Time Results...........................................................................12

FIGURE 2.5 Decay of Contamination ............................................................................. 14

FIGURE 2.6 Comparison of Computer and Observed Bacteria Concentration ..........14

FIGURE 2.7 Physical/Bacterial Decay Efficiency ..............................................................16

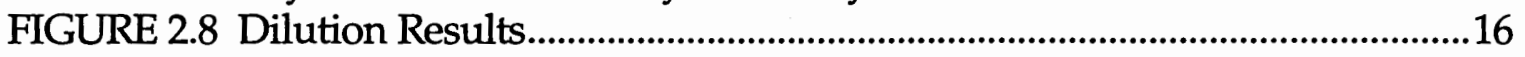

FIGURE 2.9-2.14 Minter Creek Fecal Coliform Levels............................................. 20-21

FIGURE 2.15 Results of Growth and Survival Experiments.........................................21

FIGURE 2.16 Intertidal Flats of the Annisquam River ....................................................23

FIGURE 4.1 Cell Geometry For South Slough Model ..............................................28

FIGURE 4.2 South Slough Cell Depths............................................................30

FIGURE 4.3 Topography For South Slough Estuary, Branch 1......................36-37

FIGURE 4.4 Topography For South Slough Estuary, Branch 2 2..........................38

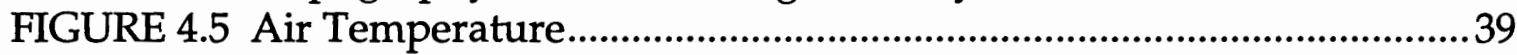

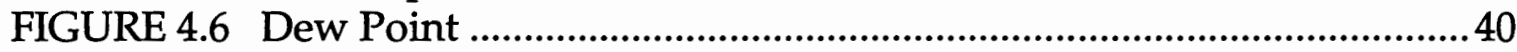

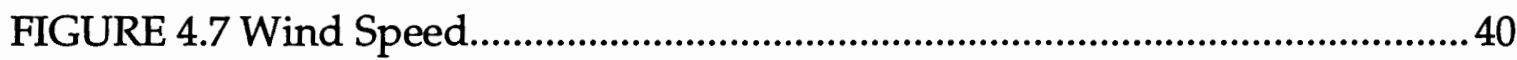

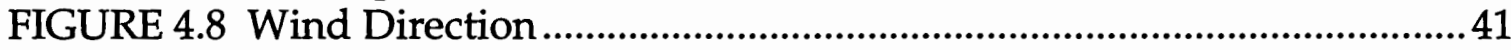

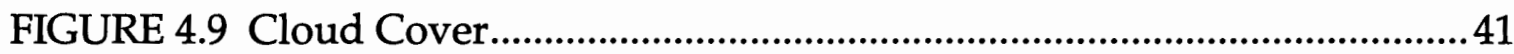

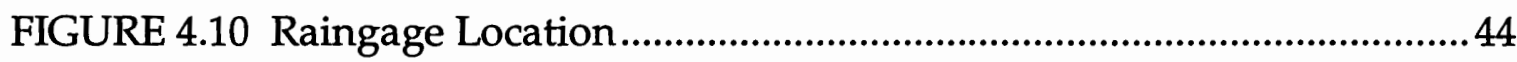

FIGURE 4.11 Rainfall North Bend Airport 1987....................................................46

FIGURE 4.12 Rainfall North Bend Airport 1988..............................................46

FIGURE 4.13 Rainfall North Bend Airport 1989..................................................4

FIGURE 4.14 Rainfall North Bend Airport 1990..................................................4

FIGURE 4.15 HEC-1 Method, Vary RTIOR..........................................................4

FIGURE 4.16 HEC-1 Method, Vary QRCSN ...........................................................49

FIGURE 4.17 HEC-1 Method, Vary TLAG.....................................................50

FIGURE 4.18 HEC-1 Method, Vary CRVNBR …................................................51

FIGURE 4.19 Rational Method (Q=1.01CIA) …................................................52

FIGURE 4.20 Compare HEC-1 and Rational Methods........................................53

FIGURE 4.21 Rainfall at North Bend Airport Calibration Period, JD 32-60 .........54

FIGURE 4.22 Flow for Talbot and John B. Creeks...........................................54

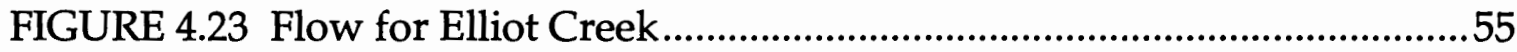

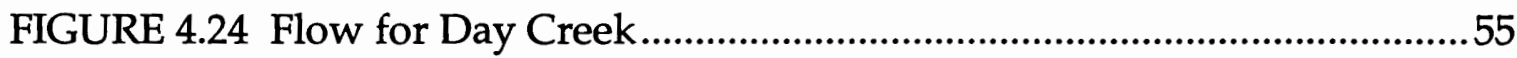

FIGURE 4.25 Flow for Hayward Creek........................................................56

FIGURE 4.26 Flow for Joe Ney Slough................................................................56

FIGURE 4.27 Flow for Winchester Creek ........................................................57

FIGURE 4.28 Charleston Harbor Water Elevations ............................................58

FIGURE 4.29 Model vs Hinch Rd Br Water Surface Elevations 
Datum $=-5.49$, Chezy $=50$......

FIGURE 4.30 Model vs Hinch Rd Br. Water Surface Elevations

Datum $=-5.49$, Chezy $=70$

FIGURE 4.31 Model vs Hinch Rd. Br. Water Surface Elevations

Datum $=-5.49$, Chezy $=95$

FIGURE 4.32 Model vs Hinch Rd. Br. Water Surface Elevations

Datum $=-5.49$, Chezy $=120$.

FIGURE 4.33 Model vs Hinch Rd. Br. Water Surface Elevations

Datum $=-5.34$, Chezy $=70$

FIGURE 4.34 Model vs Hinch Rd. Br. Water Surface Elevations

Datum $=-5.49$, Chezy $=70$

FIGURE 4.35 Model vs Hinch Rd. Br. Water Surface Elevations

Datum $=-5.64$, Chezy $=70$

FIGURE 4.36 Model vs Hinch Rd. Br. Water Surface Elevations

Datum $=-5.64$, Chezy $=70$, Increase Cell Width by $40 \%$.

FIGURE 4.37 Water Surface Elevations at Monitoring Sites .66

FIGURE 4.38 Water Elevations at Monitoring Sites, Julian Day 32 .....................66

FIGURE 4.39 Water Surface Elevations at Monitoring Sites, Julian Day 58 ........67

FIGURE 4.40 Model vs S4 Water Surface Elevations Datum $=-5.64$,

Chezy $=70.0$

FIGURE 4.41 Model vs S4 Velocity Datum $=-5.64$, Chezy $=70 \ldots \ldots \ldots \ldots \ldots \ldots \ldots \ldots \ldots . . .68$

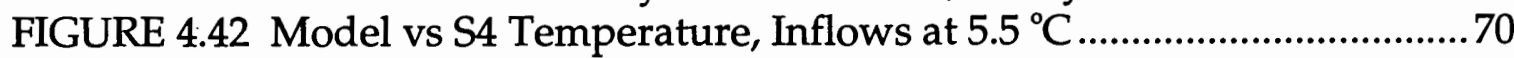

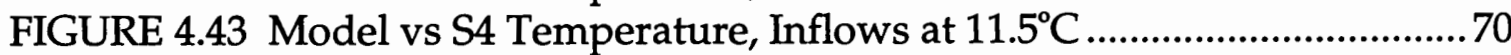

FIGURE 4.44 Air Temperature Comparison .............................................................71

FIGURE 4.45 Model vs S4 Temperature

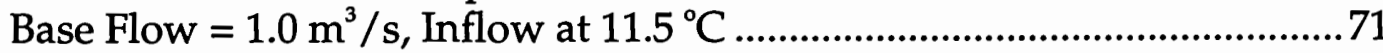

FIGURE 4.46 Model vs S4 Temperature

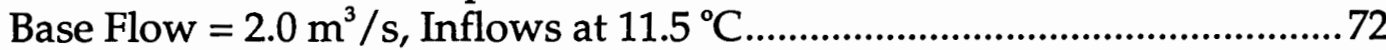

FIGURE 4.47 Model vs S4 Temperature, Inflows at $13.5^{\circ} \mathrm{C}$................................72

FIGURE 4.48 Model vs S4 Temperature, Inflow Temperature $=13.5^{\circ} \mathrm{C}$

3 Times Flow, Base Flow $=3.0 \mathrm{~m} 3 / \mathrm{s}$ .73

FIGURE 4.49 Model vs S4 Temperature, Varied Inflow Temperatures

3 Times Flow, Base Flow $=3.0 \mathrm{~m} 3 / \mathrm{s}$ .73

FIGURE 4.50 Model vs S4 Total Dissolved Solids, Initial TDS $=35,000 \mathrm{mg} / 1 \ldots .75$

FIGURE 4.51 Model vs S4 Total Dissolved Solids Initial TDS $=15,000 \mathrm{mg} / \mathrm{l}$,

Base Flow $=1.0 \mathrm{~m}^{3} / \mathrm{s}$ .75

FIGURE 4.52 Model vs S4 Total Dissolved Solids, Initial TDS $=15,000 \mathrm{mg} / \mathrm{l}$,

Base Flow $=2.0 \mathrm{~m}^{3} / \mathrm{s}$. .76

FIGURE 4.53 Model vs S4 Total Dissolved Solids

Base Flow $=2.0 \mathrm{~m}^{3} / \mathrm{s}, 2$ Times Inflow... .76

FIGURE 4.54 Model vs S4 Total Dissolved Solids

Base Flow $=3.0 \mathrm{~m}^{3} / \mathrm{s}, 2$ Times Inlow

FIGURE 4.55 Model vs S4 Total Dissolved Solids

Base Flow $=3.0 \mathrm{~m}^{3} / \mathrm{s}, 3$ Times Inflow. 
FIGURE 4.56 Model vs S4 Total Dissolved Solids

Base Flow $=3.0 \mathrm{~m}^{3} / \mathrm{s}, 4$ Times Inflow.

FIGURE 4.57 Model vs Hinch Rd. Br. Water Surface Elevations

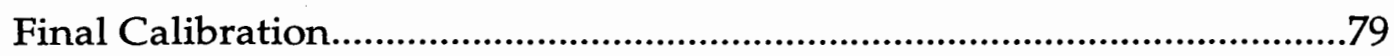

FIGURE 4.58 Model vs S4 Water Surface Elevation Final Calibration.................79

FIGURE 4.59 Model vs S4 Velocity Final Calibration .............................................80

FIGURE 4.60 Model vs S4 Temperature Final Calibration....................................8 80

FIGURE 4.61 Model vs S4 Total Dissolved Solids Final Calibration .....................81

FIGURE 4.62 Modeled Tracer, Winchester Creek, Cell 13 ..................................82

FIGURE 4.63 Modeled Tracer, Winchester Creek, Cell 25 …...............................82

FIGURE 4.64 Modeled Tracer, Winchester Creek, Cell 37 .................................... 83

FIGURE 4.65 Modeled Tracer Winchester Creek, Cell 51 .......................................83

FIGURE 4.66 Modeled Tracer, Winchester Creek, Cell 61 .....................................83

FIGURE 4.67 Modeled Tracer, Winchester Creek, Cell 64 ..................................83

FIGURE 4.68 Modeled Tracer, Winchester Creek, Cell 93 ..................................83

FIGURE 4.69 Modeled Tracer, Talbot and John B. Creeks, Cell 13 ........................84

FIGURE 4.70 Modeled Tracer, Talbot and John B. Creeks, Cell 25 ......................84

FIGURE 4.71 Modeled Tracer, Talbot and John B. Creeks, Cell 37 .......................84

FIGURE 4.72 Modeled Tracer, Talbot and John B. Creeks, Cell 51 ......................84

FIGURE 4.73 Modeled Tracer, Talbot and John B. Creeks, Cell 61 …....................84

FIGURE 4.74 Modeled Tracer, Talbot and John B. Creeks, Cell 64 .......................84

FIGURE 4.75 Modeled Tracer, Talbot and John B. Creeks, Cell 93 ......................85

FIGURE 4.76 Modeled Bacteria, Initial Input $200 \mathrm{col} / 100 \mathrm{ml}$, Cell 13...................86

FIGURE 4.77 Modeled Bacteria, Initial Input $200 \mathrm{col} / 100 \mathrm{ml}$, Cell 25 ..................86

FIGURE 4.78 Modeled Bacteria, Initial Input $200 \mathrm{col} / 100 \mathrm{ml}$, Cell 37 .................86

FIGURE 4.79 Modeled Bacteria, Initial Input $200 \mathrm{col} / 100 \mathrm{ml}$, Cell 51 ...................86

FIGURE 4.80 Modeled Bacteria, Initial Input $200 \mathrm{col} / 100 \mathrm{ml}$, Cell 61..................86

FIGURE 4.81 Modeled Bacteria, Initial Input $200 \mathrm{col} / 100 \mathrm{ml}$, Cell 64 ..................86

FIGURE 4.82 Modeled Bacteria, Initial Input $200 \mathrm{col} / 100 \mathrm{ml}$, Cell 93 .................8. 87

FIGURE 4.83 Modeled Bacteria,

Inflow Concentration 1,000 col/100 ml, Cell 13.........................................8

FIGURE 4.84 Modeled Bacteria,

Inflow Concentration 1,000 col/100 ml, Cell 25.........................................8

FIGURE 4.85 Modeled Bacteria,

Inflow Concentration 1,000 col/100 ml, Cell 37.....................................88

FIGURE 4.86 Modeled Bacteria,

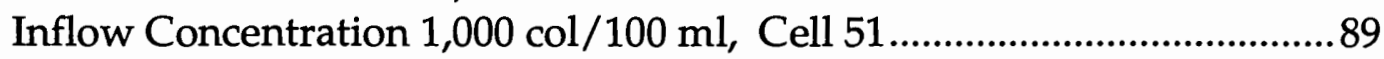

FIGURE 4.87 Modeled Bacteria,

Inflow Concentration 1,000 col/100 ml, Cell 61........................................89

FIGURE 4.88 Modeled Bacteria,

Inflow Concentration 1,000 col/ $100 \mathrm{ml}$, Cell 64.......................................90

FIGURE 4.89 Modeled Bacteria,

Inflow Concentration 1,000 col/100 ml, Cell 93.......................................99

FIGURE 4.90 Bacteria Concentrations for Vertical Layers ................................... 92 
FIGURE 4.91 Bacteria Histogram for Cell 13 ....................................................... 95

FIGURE 4.92 Bacteria Histogram for Cell 25 .......................................................95

FIGURE 4.93 Bacteria Histogram for Cell 37 .........................................................96

FIGURE 4.94 Bacteria Histogram for Cell 51 …..................................................96

FIGURE 4.95 Bacteria Histogram for Cell 61 ......................................................97

FIGURE 4.96 Bacteria Histogram for Cell 64 .......................................................97

FIGURE 4.96 Bacteria Histogram for Cell 93 ….....................................................98 


\section{LIST OF TABLES}

TABLE 2.1 Minter Creek Fecal Coliform .........................................................................19

TABLE 2.2 Minter Creek Results of Growth and Survival Experiments .....................19

TABLE 4.1 South Slough Model Cell Widths for Branch 1 ....................................... 31-33

TABLE 4.2 South Slough Model Cell Widths for Branch 2 ....................................... 34-35

TABLE 4.3 Boundary Condition for Temperature .............................................................59

TABLE 4.4 Modeled Bacteria Concentration Statistics

for Inflow Concentrations of 1,000 col/100 ml ....................................................91

TABLE 4.5 Shellfish Harvest Closure for 1990 ............................................................94

\section{LIST OF PHOTOS}

PHOTO 1 South Slough Estuary near Interpretive Center........................................... vii 


\section{Acknowledgments}

I appreciate the support of my advisor, Dr. Scott Wells, Portland State University Department of Civil Engineering. Appreciation is also expressed to my coworker, Arnel Mandilag, for his graphics expertise and assistance.

The technical report "Field Survey Data Summaries, South Slough, Oregon, July 1989 - September 1990", by Scott Wells and Brad Baird provided the field data for this paper.

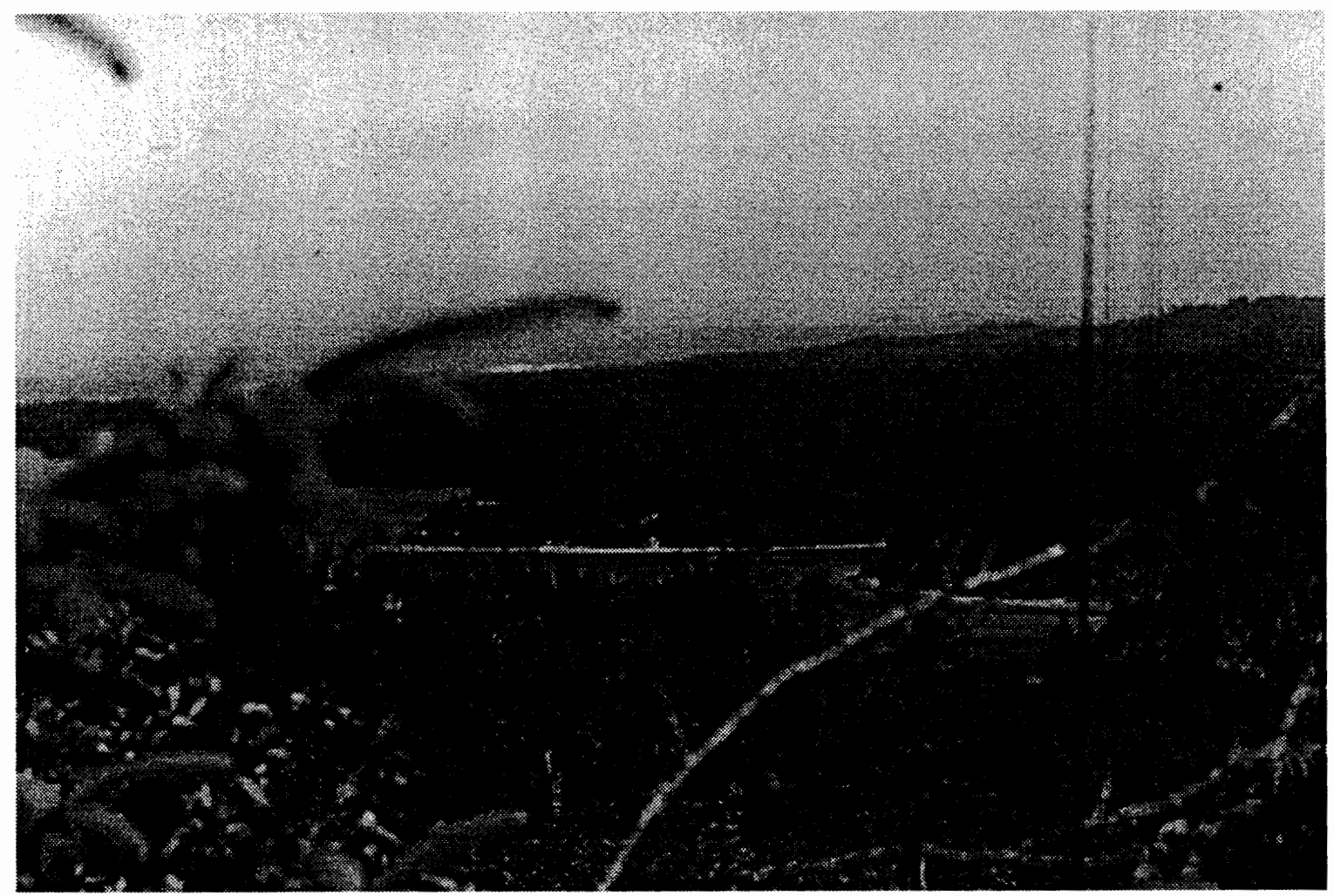

Photo 1 South Slough Estuary near Interpretive Center 


\section{INTRODUCTION}

\section{A Location and System Description}

The South Slough Estuary is located off Coos Bay along the southern coast of Oregon, see Figure 1.1. South Slough covers about $20.23 \mathrm{~km}^{2}$ of land with a drainage area of over $72.84 \mathrm{~km}^{2}$. It is about $7.62 \mathrm{~km}$ long and is divided into two channels that meet at Valino Island and continue north to Coos Bay at the Charleston Harbor. It is over $610 \mathrm{~m}$ wide at the northern end and up to $1.2 \mathrm{~m}$ deep at mean low water in the east and west channel areas south of Valino Island. The west arm is fed by Winchester Creek, the largest tributary contributing to the estuary. The east arm begins with flow from John B Creek and Talbot Creek then further downstream is fed by Elliot Creek. After the west and east arms meet at Valino Island, Day creek and Joe Ney Slough feeds the South Slough on the east side and the Hayward Creek on the west side. A detailed diagram of the South Slough is shown in Figure 1.2.

The maximum velocities, in the slough are approximately $3 \mathrm{ft} / \mathrm{s}(1 \mathrm{~m} / \mathrm{s})$ and average velocities $1 \mathrm{ft} / \mathrm{s}(0.4 \mathrm{~m} / \mathrm{s})$. The South Slough Estuary is usually wellmixed vertically (except during storm events) with strong longitudinal salinity gradients. Temperature range is between 5 to $23^{\circ} \mathrm{C}$, longitudinal variation in temperature between 2 and $5^{\circ} \mathrm{C}$. During 1989, tidal heights at Charleston Harbor ranged from $5.5 \mathrm{ft}$ NGVD to $-7.7 \mathrm{ft}$ NGVD. Field data of the South Slough estuary were described in Wells and Baird (1990).

\section{B Problem Statement}

After rainfall events, the level of coliform bacteria in the slough increases because of stream bacteria loading. This is due to cattle grazing in the Winchester Creek and other drainage areas, failed septic systems from private homes, and sewage sludge applied to the County landfill, which drains into the slough east of Valino Island.

Under the ORS 622.180 the Oregon Health Division has enforced a Sanitation Management Plan for Commercial Shellfish Harvesting in Joe Ney and South Slough that specifies closure of commercial shellfish harvesting under certain conditions. This plan was approved May 25, 1988 and is shown in Appendix A. One of the conditions for closure of shell fishing is rainfall and flood events. The Shellfish Management Plan states, "When the 5-day rainfall total is 5 inches or there is more than 1.5 inches of rain in any given day, Joe Ney and South Slough shall be closed." Rainfall is measured at the North Bend airport. Shellfish harvesting remains closed for "at least 5 days or until there have been five 
FIGURE 1.1

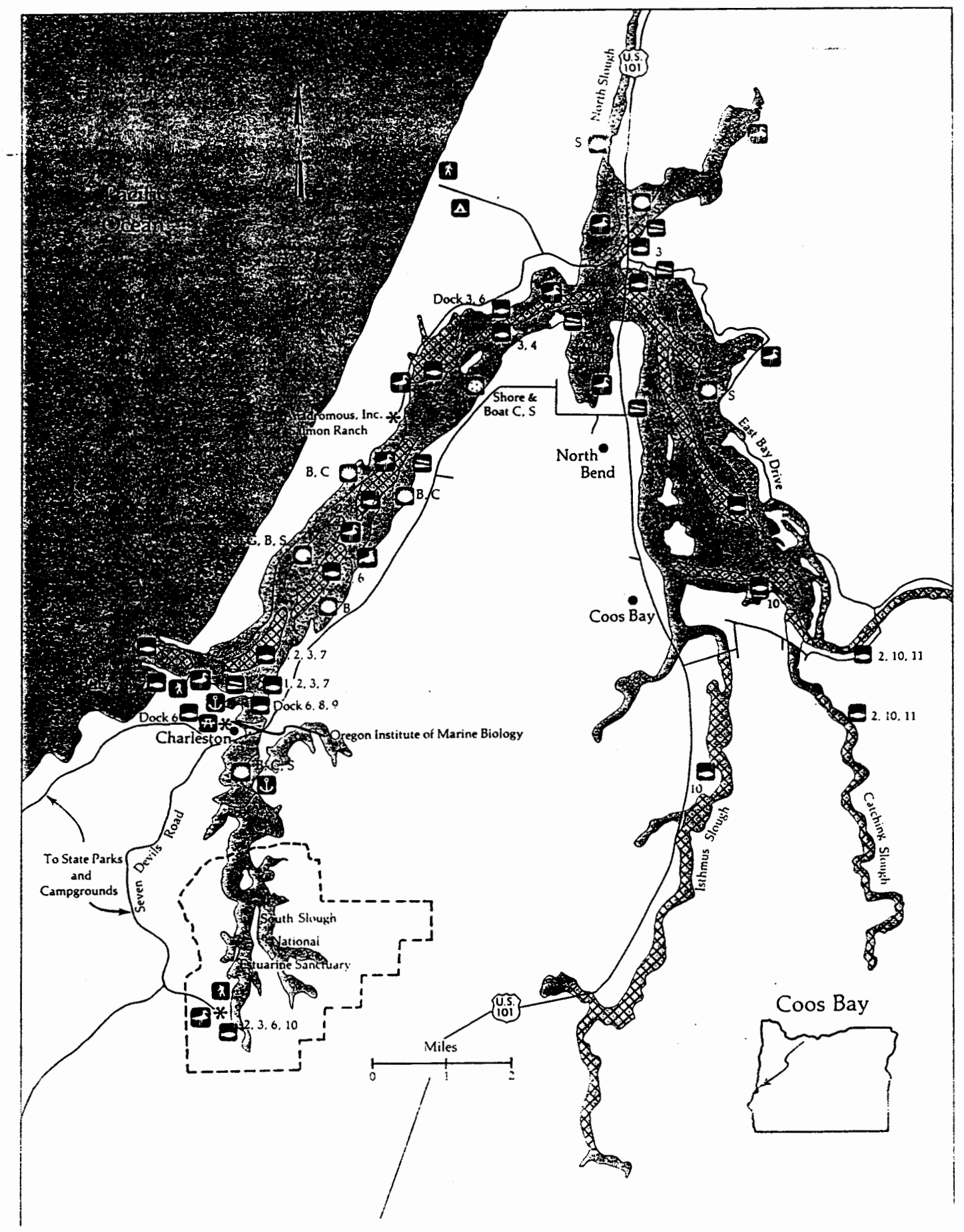


FIGURE 1.2

South Slough estuary

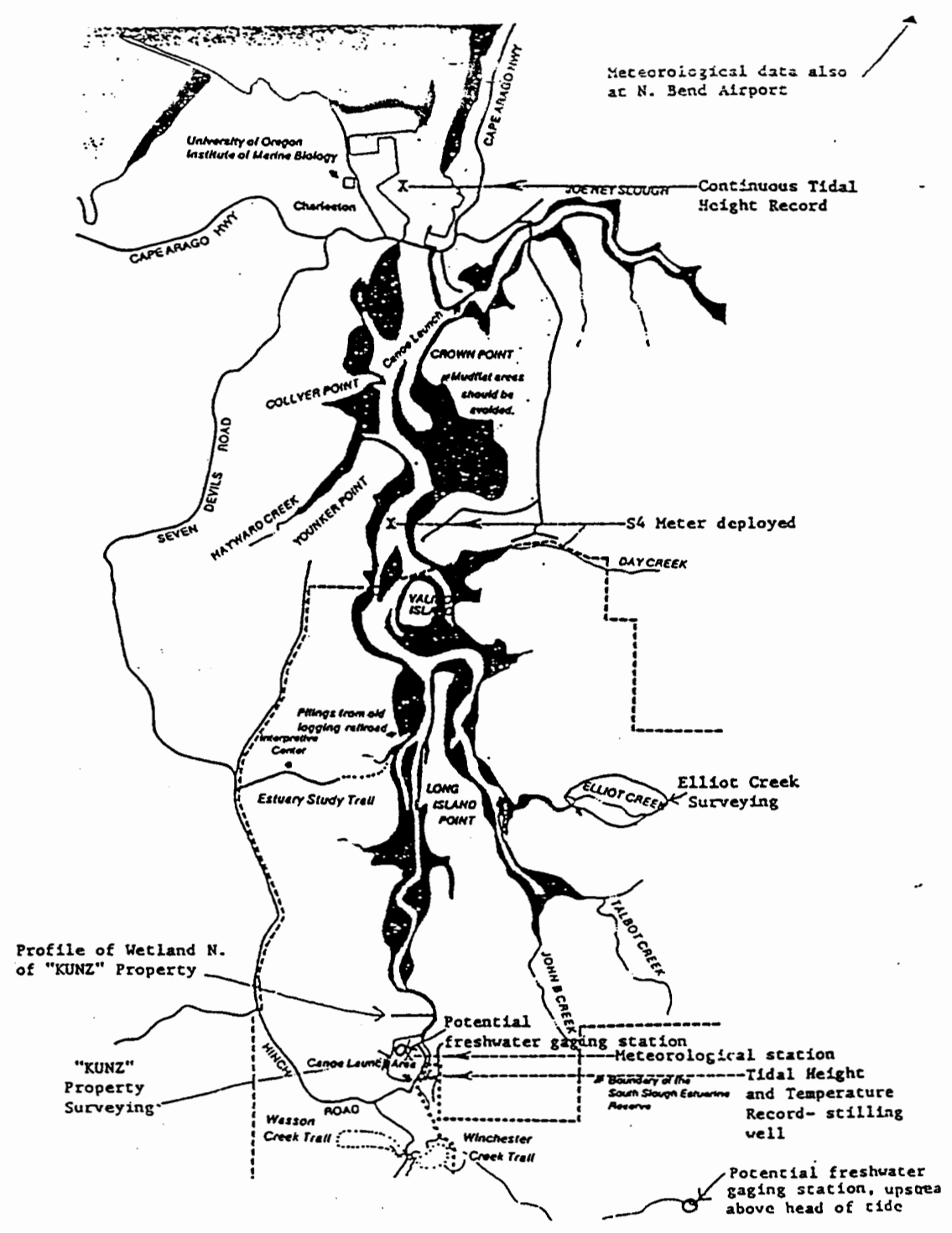


consecutive days below the 5 inch rain total and none of the five days with rainfall exceeding 1.5 inches". The Health Division notifies the harvester when the shellfish harvesting is reopened. The Shellfish Management Plan may be modified by presenting a proposal to the South Slough Shellfish Task Force. The task force will review the proposal and make recommendations to the Health Division. The Health Division has final authority for modifications to the management plan.

The purpose of this paper is to analyze and improve the current understanding of the hydraulics and water quality of the South Slough Estuary. This will be done by calibrating a water quality model of South Slough using collected field data. A management analysis was performed by examining an conservative tracer and bacteria transport.

\section{Organization of Project}

This paper is organized into six sections, Section I being the introduction. Section II of this paper is a literature review of publications covering different aspects of shellfish and bacteria pollution. Section III is an overview of the water quality model used to calibrate the South Slough Estuary, CE-QUAL-W2. A description of the model and the theoretical background is provided.

The major section of this paper covers the development, calibration and use of South Slough Model, Section IV. The information required to setup the South Slough model are provided and the development of the input data; model geometry, meteorological data, inflow data and downstream boundary conditions. Also included in this section is the calibration process of the hydraulics, temperature and total dissolved solids of the South Slough Estuary. The final topic in section IV is a management analysis of a conservative tracer and bacteria transport and distribution. This paper examines several hypothetical scenarios of tracer and bacteria concentration inputs.

The final two sections of this paper are the conclusions and references, sections $\mathrm{V}$ and VI respectively.

\section{LITERATURE REVIEW}

\section{A Introduction}

This literature review examines four publications, each covering a different aspect of shellfish and bacteria pollution. The first publication is by P.C. Wood entitled 
"Public Health Aspects of Shellfish from Polluted Waters". Wood (1979) discusses the feeding mechanisms of shellfish and the effects of polluted water on shellfish.

The second article "Mathematical Model of Bacterial Contamination of the Morlaix Estuary (France)" was written by Jean Claude Salomon and Monique Pommepuy. Salomon and Pommepuy (1990) describe a model of the transport of bacteria from a Sewage Treatment Plant to the Morlaix Estuary. The model was developed to provide management suggestions to improve water quality and minimize fecal pollution in shell-fishing areas.

In the third article Struck (1988) analyzes the effect of contaminated sediments and the relationship between water quality and sediment contamination in the Puget Sound Estuary. Polluted by non-point source fecal coliform, six commercial shellfish areas were closed in 1978 in the Puget Sound Estuary. "The Relationship Between Sediment and Fecal Coliform Levels in a Puget Sound Estuary" was written by Philip H. Struck.

The final review was of "The Shellfish Resource in a Polluted Tidal Inlet" by Thomas Hruby. Hruby (1981) covers the monetary benefits of implementation of antipollution measures in shell-fishing areas. This benefit-cost analysis of the Annisquam River only includes direct benefits from selling harvested shellfish versus the cost of a sewage treatment plant.

\section{B Review}

\section{1. "Public Health Aspects of Shellfish from Polluted Waters"}

Oysters, clams, mussels, cockles and escallops are all considered filter feeders. Filter feeders take in large volumes of sea water. The sea water is then filtered through the gills to extract unicellular flagellates along with food, which is then passed into the digestive tract. Along with the food fecal micro-organisms are also extracted. According to the author there is "much evidence to show that the digestion process does not inactivate these organisms (fecal organisms)... ." Filter feeders then become vulnerable to accumulation of fecal bacteria.

What affects the bacterial content in filter feeders? Salinity and temperature affect the filtration rate of fecal organisms. As the water temperature increases, so does the filtration rate, and therefore there is a concentration increase with a increase in water temperature. The reverse is also true, "In winter at temperature of $2^{\circ} \mathrm{C}$ and below, oysters did not respond, but maintained a low concentration of bacteria, even though there was a massive increased in polluting bacteria in the overlying water." 
In estuaries, or in areas where water quality varied with tidal current, oysters and mussels responded immediately to water quality changes. This rapid response implies that filter feeders can discard accumulated bacteria when water quality improves. If this is so, bacteria do not penetrate the tissues but remain in the alimentary tract or on gill or mantle surfaces and are removed by normal feeding process. There is however, insufficient evidence that enteric virus particles are removed in the same process. According to the author there is indication that viruses may be retained in shellfish for long periods, particularly during the winter.

At this time, there seems to be no reliable way to compare the presence of fecal bacteria in molluscan shellfish to water concentration due to variation in filtration rate, change in response to water temperature, salinity, concentration of suspended matter and presence of food organisms. By monitoring water quality regularly, one may be able to determine certain pollutant trends and thus the quality of shellfish. However, with so many variables, the only way to be certain if shellfish are fit for human consumption is to examine a representative sample of shellfish.

\section{2. "Mathematical Model of Bacterial Contamination of the Morlaix Estuary (France)"}

The Morlaix estuary is located on the northern coast of Brittany. The upper section is $5.5 \mathrm{~km}$ long and begins at the city of Morlaix (see Figure 2.1). The upper section includes the Morlaix river which travels for $4 \mathrm{~km}$ and meets the Dourduff River. Where the Dourduff River meets the estuary is a shallow and narrow area with ranges in width from $100 \mathrm{~m}$ at high tide down to $10 \mathrm{~m}$ at low tide. The outer estuary is $5 \mathrm{~km}$ long and up to $3.5 \mathrm{~km}$ wide narrowing to $1 \mathrm{~km}$ at the sea. The estuary is used by oyster breeders as shown in Figure 2.1.

The bacterial input is mostly due to the sewage treatment plant (STP) of the City of Morlaix. The plant is at the upstream portion of the estuary near a sluice gate. Estimated fluxes are $0.16 \times 19^{9}$ Entero-bacteria colonies/second from the inflowing rivers and $7 \times 10^{9}$ from the STP.

Since the behavior of the bacteria is closely related to the current behavior, the aim of this model was to have a comprehensive description of water movements. Complexity and financial cost of a three dimensional model were considered prohibitive constraints. Therefore, seaward from the Dourduff river, the outer estuary, was modeled with a two dimensional model in the horizontal plane (2DH). The upper section then was modeled with a one dimensional model (1DH) with a distinct branch for the two main rivers. 


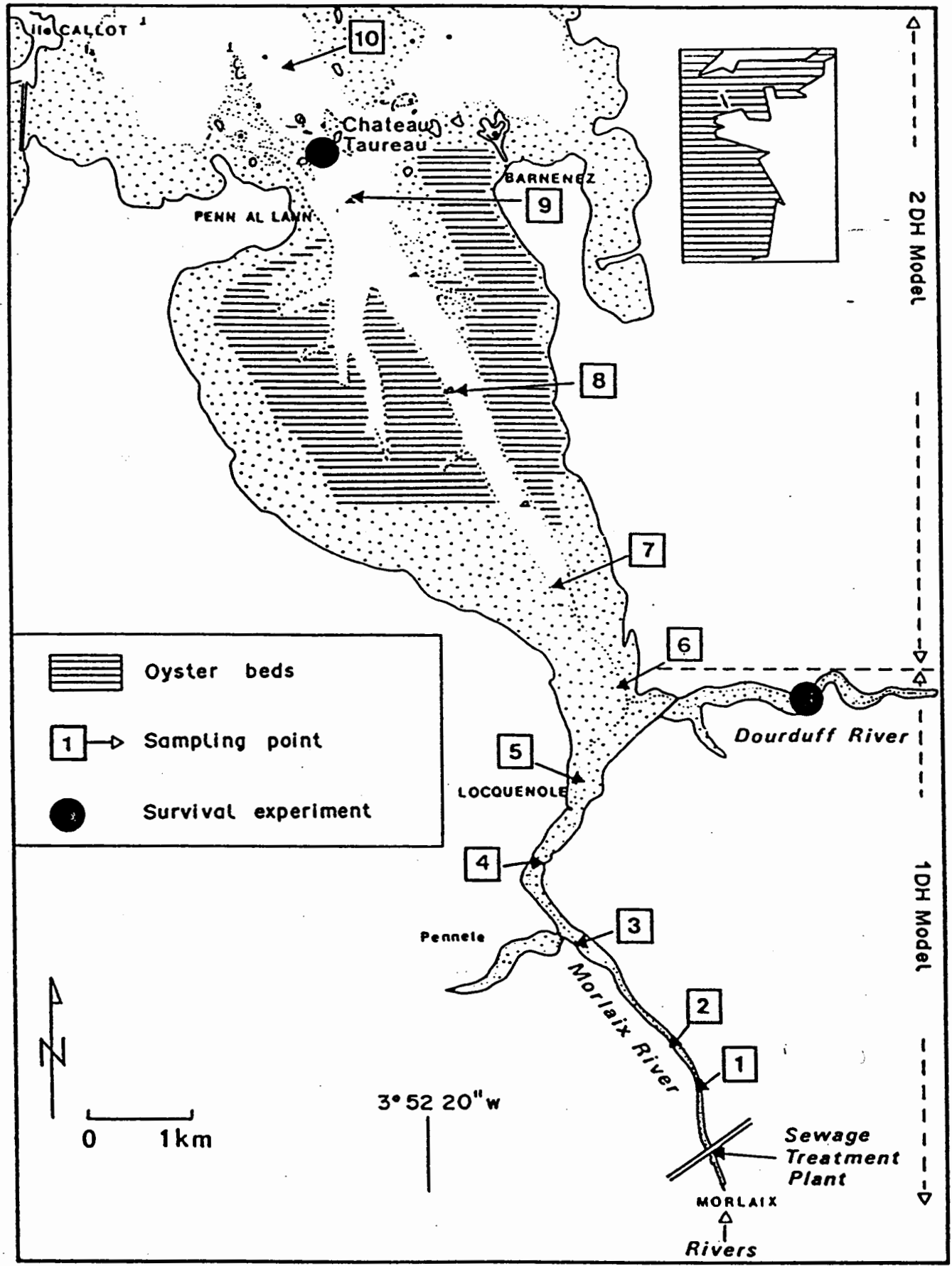

FIGURE 2.1 Map of the Morlaix estuary. 
The equations used in this model for the hydrodynamics were as follows:

\section{DH Model}

$$
\begin{gathered}
\frac{\partial u}{\partial t}+u \frac{\partial u}{\partial x}+v \frac{\partial u}{\partial y}-f v+g \frac{\partial h}{\partial x}+g u \frac{\sqrt{\mu^{2}+v^{2}}}{k_{r}^{2} H^{4 / 3}}-\mu\left(\frac{\partial^{2} u}{\partial x^{2}}+\frac{\partial^{2} u}{\partial y^{2}}\right)=0 \\
\frac{\partial v}{\partial t}+u \frac{\partial v}{\partial x}+v \frac{\partial v}{\partial y}-f u+g \frac{\partial h}{\partial y}+g v \frac{\sqrt{u^{2}+v^{2}}}{k_{r}^{2} H^{4 / 3}}-\mu\left(\frac{\partial^{2} v}{\partial x^{2}}+\frac{\partial^{2} v}{\partial y^{2}}\right)=0 \\
\frac{\partial h}{\partial t}+\frac{\partial(h u)}{\partial x}+\frac{\partial(h v)}{\partial y}=0
\end{gathered}
$$

1DH Model

$$
\frac{\partial u}{\partial t}+u \frac{\partial u}{\partial x}+g \frac{\partial h}{\partial x}+g \frac{u|u|}{k_{r}^{2} R_{h}^{4 / 3}}-\mu \frac{\partial^{2} u}{\partial x^{2}}=0
$$

$$
\frac{\partial \sigma_{t}}{\partial t}+\frac{\partial\left(\sigma_{c} u\right)}{\partial x}=0
$$

where

$$
\begin{aligned}
& (u, v)=\text { velocity components } \\
& (x, y)=\text { horizontal coordinates } \\
& t=\text { time } \\
& h=\text { surface level } \\
& H=\text { water depth } \\
& f=\text { Coriolis factor } \\
& k_{r}=\text { friction coefficient }
\end{aligned}
$$




$$
\begin{aligned}
& \mu=\text { horizontal viscosity } \\
& R_{h}=\text { hydraulic radius } \\
& \sigma_{t}=\text { total cross-section } \\
& \sigma_{c}=\text { channel cross-section }
\end{aligned}
$$

The $2 \mathrm{DH}$ and the $1 \mathrm{DH}$ were linked so the only boundary conditions required were the tidal amplitude in the sea and the water discharge of the two rivers. The equations were solved using finite difference techniques. The grid size for this model was $250 \mathrm{~m}$.

The equations for advection/dispersion were as follows:

$\underline{2 \mathrm{DH}}$

$$
\frac{\partial H C}{\partial t}+\frac{\partial(H u C)}{\partial x}+\frac{\partial(H v C)}{\partial y}-\varepsilon\left(\frac{\partial\left(H \frac{\partial C}{\partial x}\right)}{\partial x}+\frac{\partial\left(H \frac{\partial C}{\partial y}\right)}{\partial y}\right)=0
$$

$\underline{1 \mathrm{DH}}$

$$
\frac{\partial\left(\sigma_{t} C\right)}{\partial t}+\frac{\partial\left(\sigma_{c} u C\right)}{\partial x}-\frac{\partial\left(\varepsilon \sigma_{c}\left(\frac{\partial C}{\partial x}\right)\right)}{\partial x}=0
$$

where

$$
\begin{aligned}
& C=\text { concentration } \\
& \varepsilon=\text { horizontal dispersion }
\end{aligned}
$$

The same schematization was obeyed for the advection dispersion model as was for the hydrodynamics. The advection-dispersion equations were also solved by a finite difference technique, second order accurate in time and third order in space.

Sampling trips were done to estimate fecal contamination. Several hydrodynamic and seasonal conditions were investigated. Sampling points are shown on Figure 2.1. Water from the STP was sampled every 2 hours over a 24 hour period. Most of the bacteria found in these samples were Escherichia coli, Enterobacter, Klebsiella and Citrobacter. Survival experiments were carried out in the field to 
determine the die-off rate.

In the outward section near the sea the salinity, turbidity, and temperature were almost constant; $36.2 \%, 2.5 \mathrm{mg} / 1$ and $14{ }^{\circ} \mathrm{C}$, respectively, in the summer, and $35 \%$, $7.8 \mathrm{mg} / 1$ and $9{ }^{\circ} \mathrm{C}$ in the winter. The extinction coefficient was $0.26 / \mathrm{m}$.

In the Dourdoff estuary the salinity ranged from 0 to $15 \%$, temperature averaged $15.8{ }^{\circ} \mathrm{C}$ in the summer and $8.6^{\circ} \mathrm{C}$ in the winter, turbidity from 15 to $120 \mathrm{mg} / \mathrm{l}$, and the extinction coefficient 1 to $3.5 / \mathrm{m}$.

The equations for the bacteriological model are the same as equations 6 and 7 except for the sink/source term. A first-order reaction rate was used:

$$
\frac{d c}{d t}=-k c
$$

Where $\mathrm{k}$ is the first order decay coefficient.

Another parameter used was the time needed for $90 \%$ of bacteria to die defined as:

$T 90=2.3 / k$

The hydrodynamic simulation revealed that there was a fast renewal of the waters explaining the predominance of marine regime of the estuary. Figure 2.2 shows the long term current behavior. The dots represent drifters that were released at mid-flood and reported every 2 hours. At mid-ebb lateral drifters were carried out of the bay while those in the channel remained inside. This is significant when examining contamination of oyster beds.

Salinity was used for verification and tuning of the hydrodynamic part of the model. Figure 2.3 shows some results in salinity concentration comparison of model versus measurement. The main error was due to the fact that the upper estuary is stratified where the model was not. The salinity model predictions correlated well to field data for spring and neap tide during high tide. Low tide predictions did not correlate well with data. The computed values were high in 


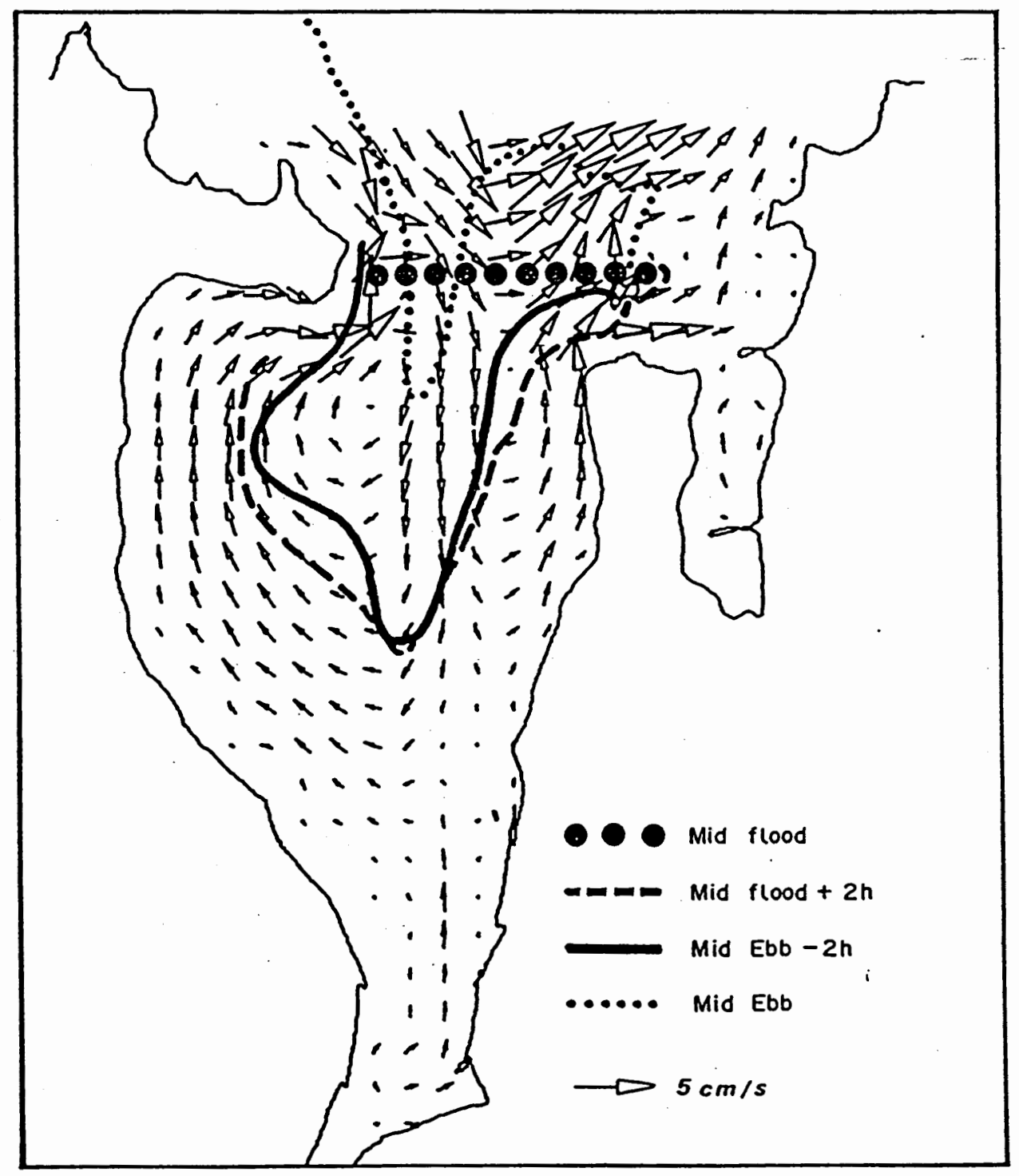

FIGURE 2.2 Residual velocities and drifter movements. 

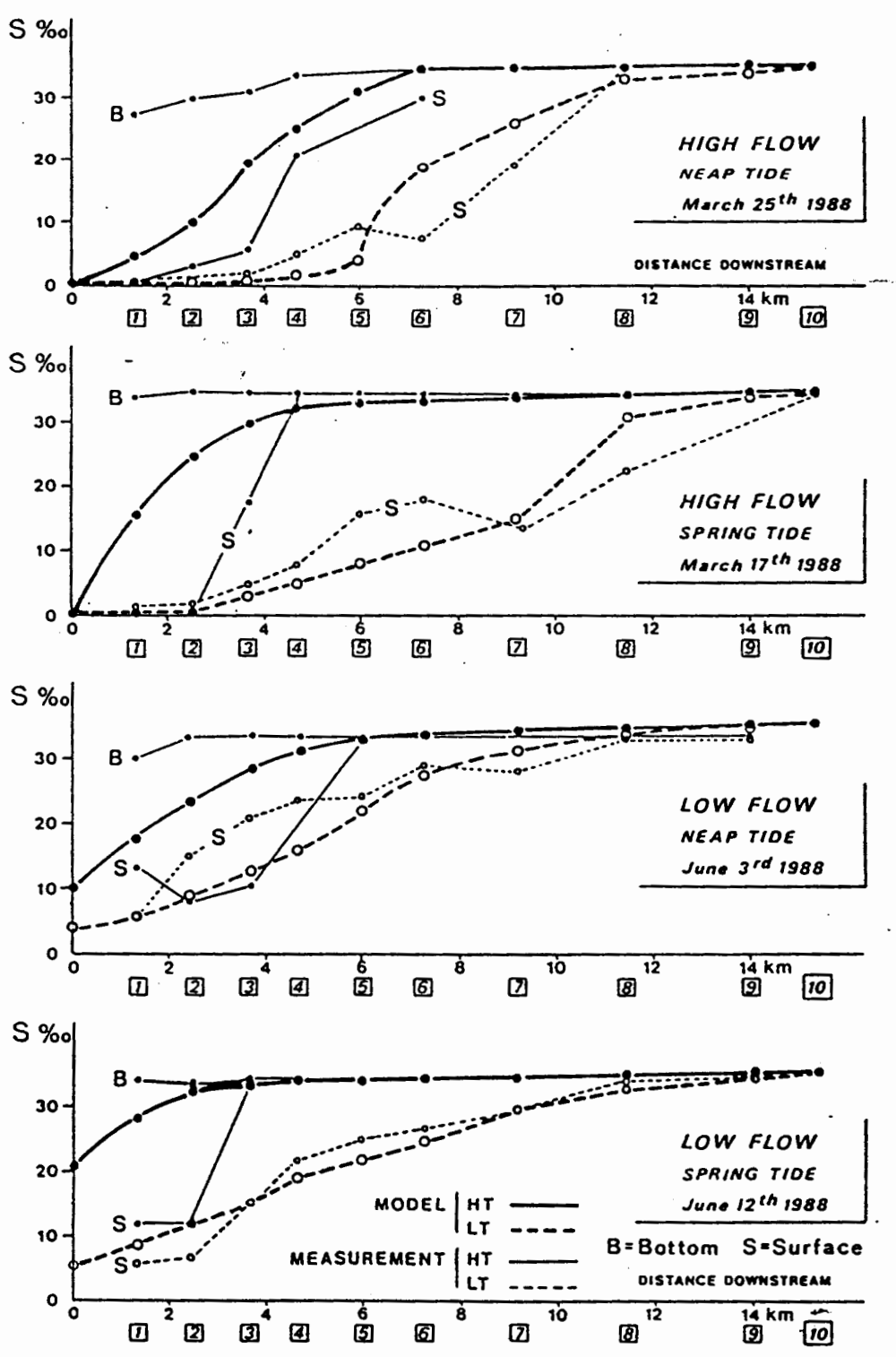

FIGURE 2.3 Comparison between observed and computed salinities.

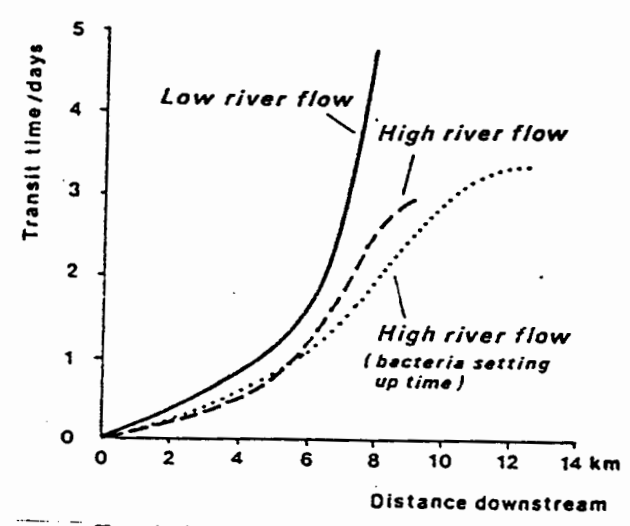

FIGURE 2.4 Transit times deducod from fresh water content and bacterial concentration. 
upper reaches and low in lower reaches of the Morlaix River, then correct in the 2D model of Morlaix Estuary. Areas of poor correlation were also due to effects from wind, waves or the locations where measurements were carried out, in a boat or on the shore. Drainage of mud banks and smaller tributaries that were not included in the model may have also affected results.

The author defined the transit time or residence time as "the average time needed by particles released at the head of the estuary to reach any downstream location." The equation used for the 1D analysis was:

$$
\frac{\int_{x}^{L} \int_{0} \frac{S_{0}-S}{S_{0}} d \sigma d x}{Q}=t(x)
$$

where:

$$
\begin{aligned}
& L=\text { head of estuary } \\
& S=\text { local salinity } \\
& S_{o}=\text { marine salinity } \\
& Q=\text { fluvial discharge }
\end{aligned}
$$

The results for the transit time are shown in Figure 2.4. For the first $8 \mathrm{~km}$ of the estuary during low river outflow, the transit time was from 0 to 5 days. During high river discharge, the transit time was only 2.5 days.

The bacteria T90 values were observed as follows: For near the sea, T90 $=2.2 \mathrm{hr}$ to 2.6 days, and for very sunny days T90 $=2$ days. This area generally has high turbidity and low sunlight and therefore more often 1-2 days. Inside the estuary $\mathrm{T} 90=9-10$ days, due to the high turbidity which decreases the light penetration.

Initially the model did not include decay conditions. Bacteria were treated as a conservative element. Figure 2.5 shows the progressive decay of contamination at different sampling locations. It shows a decrease of contamination of sewage from $10^{7}$ bacteria $/ 100 \mathrm{ml}$ at the top of the estuary to $10^{2}$ near Penn-al-lann.

Comparison of transit times and die off rates indicates which areas will be contaminated. When it is sunny and the water is clear, only the upper reaches are contaminated. In the winter when it is cloudy and turbidity is high, only dilution is reducing bacterial contamination. 


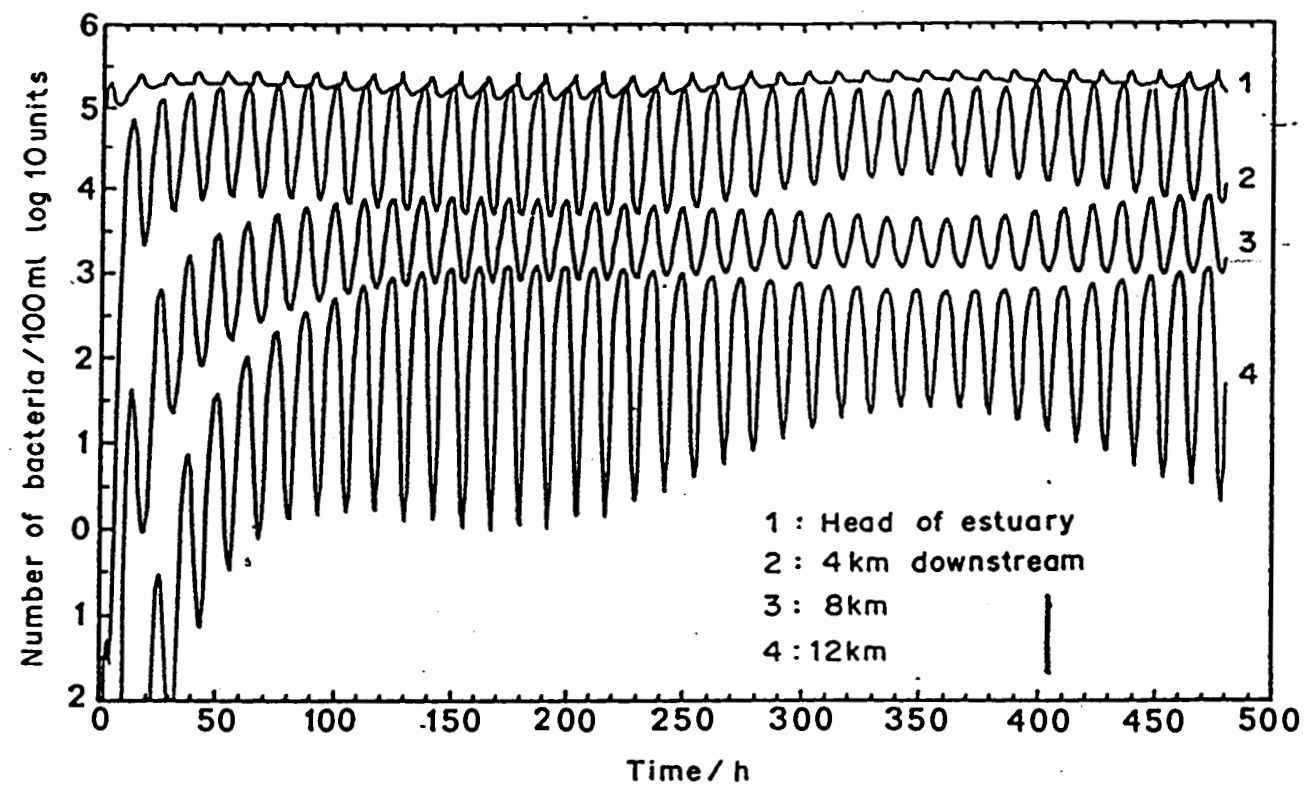

FIGURE 2.5 Model results with no die-off terms.

A

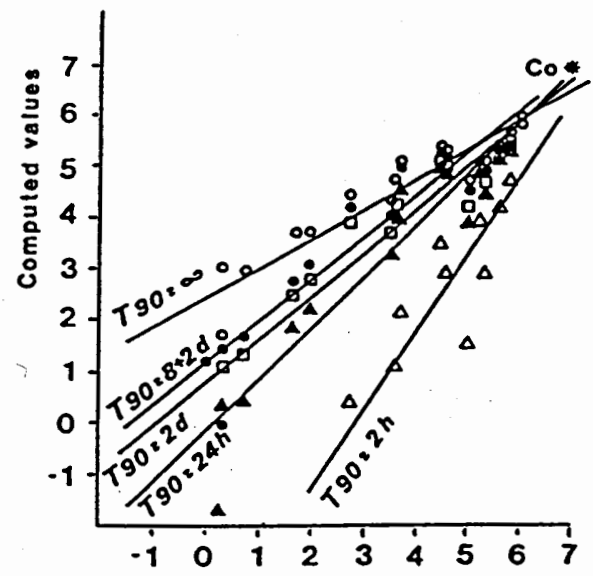

B

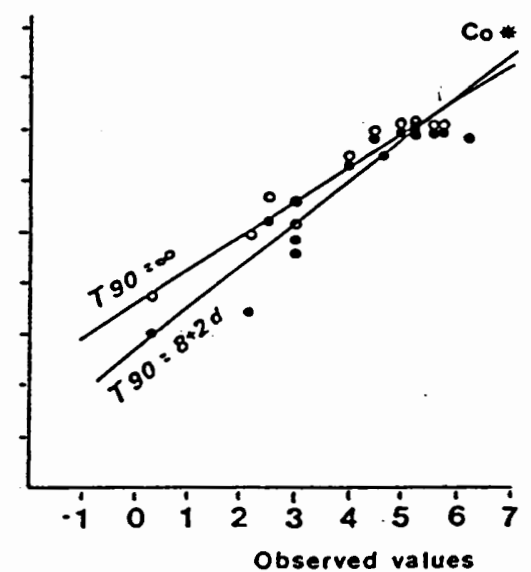

FIGURE 2.6 Computed vs measured bacterial concentrations (expressed in $\log _{10}$ of bacterial concentration $/ 100 \mathrm{ml}$ ). $C_{0}=$ initial value. (A) Summer (3 June 1987), (B) winter (15 Oct. 1987). T90 $=\infty$ (O); $T 90=8+2$ days $(O) ; T 90=2$ days $(\square) ; T 90=24$ h $(\Delta) ; T 90=2$ h $(\triangle)$. 
Figure 2.6 compares computed and observed bacterial concentrations. Upstream model results compare well, whereas downstream results are too high by a factor of a few tenths. Low tide measurements were 3 times higher than computed values in the upstream extremity due to incomplete lateral mixing of effluent, or high turbidity.

Different T90 values were used to determine the best decay factor. For summer conditions of low river flow, there was little difference in bacteria concentration for T90 ranging between 2 and 8 days. Physical factors were thus the dominant mechanisms for reducing bacteria concentrations. The best agreement for summer conditions was a T90 of 24 hours. A more detailed examination showed that upstream the biological factors, decay, did not play much of a role in reducing bacteria concentrations but a physical process, dilution did. However, downstream both biological factors and physical processes played equal roles.

For winter (high river flow conditions) $\mathrm{T} 90=8$ days upstream, and $\mathrm{T} 90=2$ days downstream. Physical process was more important than biological effects during winter conditions for both upstream and downstream.

Time variations in bacterial contamination are shown in Figure 2.8. There was more polluted water coming from upstream during low tide and renewed water entering the estuary during high tide. Tidal effects resulted in great variations of contamination on the estuarine axis. The lateral zones did not experience these variations but remained either emerged or covered by contaminated water. The oyster beds were located here and were never exposed to pure marine water.

The relative efficiency of bacterial mortality and physical dilution were compared. Physical mechanisms were described by the parameter:

$$
\operatorname{phy}(x)=C_{0} / C^{\prime}(x)
$$

where

$C^{\prime}(\mathbf{x})=$ concentration throughout estuary for $\mathrm{T} 90=\infty$

$\mathbf{C}_{0}=$ concentration in sewage outfall

The biological factors were quantified by the parameter:

$$
\operatorname{Bio}(x)=C^{\prime}(x) / C(x)
$$




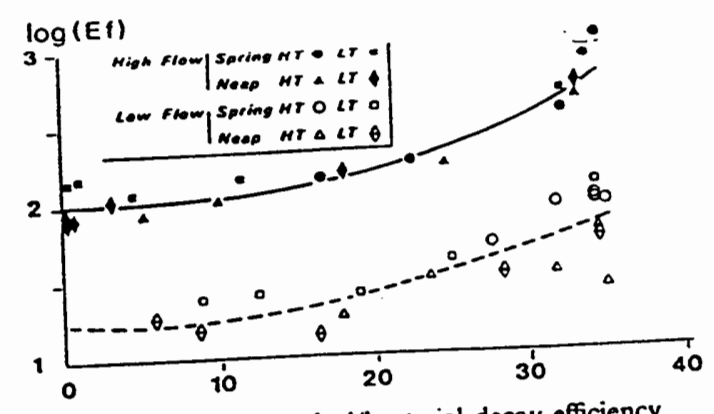

FIGURE 2.7 Relative physical/bacterial decay efficiency.
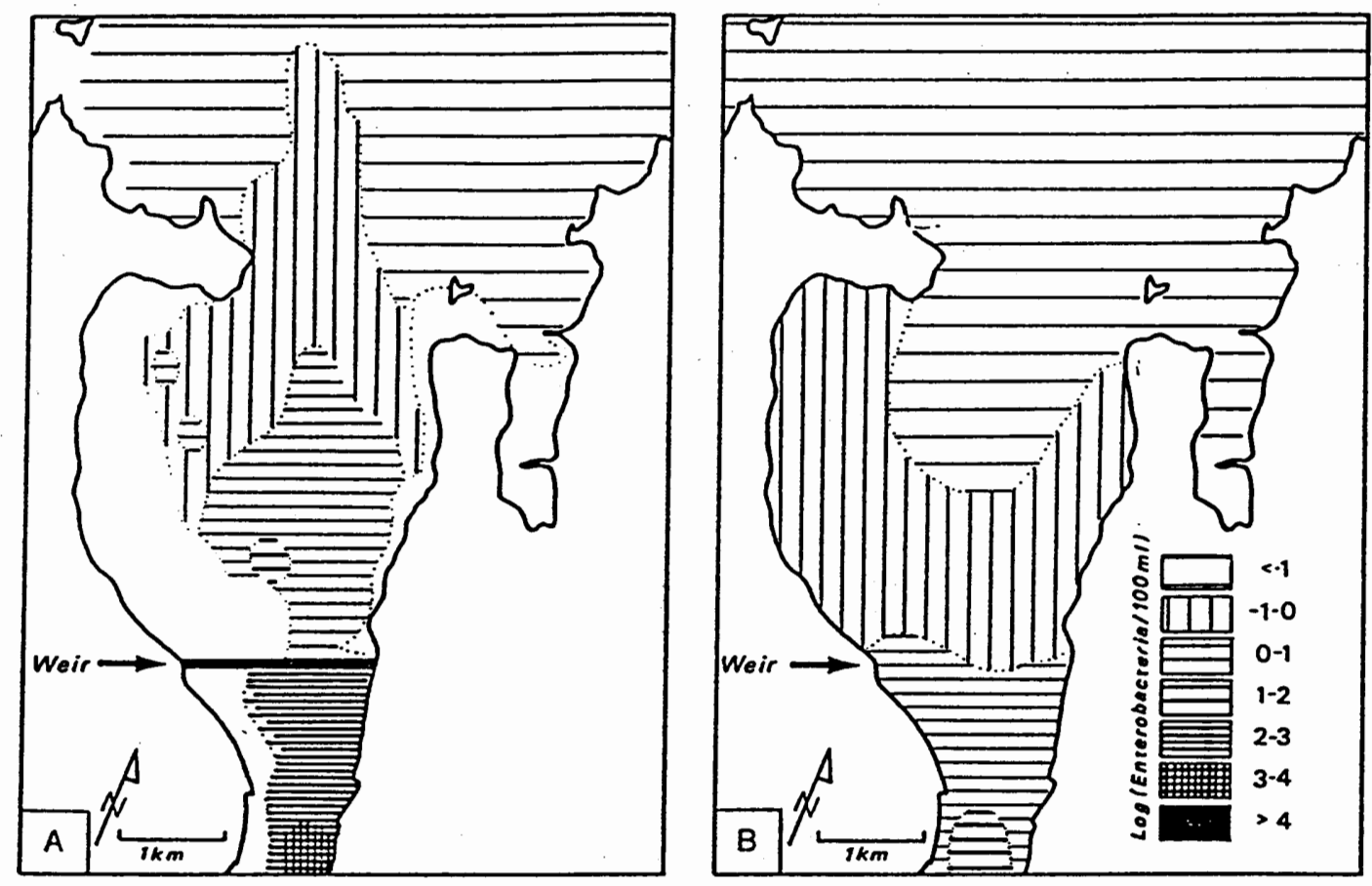

FIGURE 2.8 Concentration map in a modified estuarine geometry. (A) Low tide; (B) high tide. 
where

$$
\mathbf{C}(\mathbf{x})=\text { real bacterial concentration }
$$

The relative physical versus biological efficiency was calculated as:

$$
E f(x)=p h y(x) / B i o(x)=C_{0} C(x) / C^{\prime}(x)^{2}
$$

The relative physical/bacterial decay efficiency is plotted in Figure 2.7. From this figure the physical mechanisms were shown to be more efficient in reducing bacterial sanitary risk than the mortality. The physical mechanisms dominate due to currents by a high tidal regimen. Irregularities in bathymetry and the existence of two rivers gives a great capacity for dispersion. High turbidity, moderate isolation and abundance of nutrients made bacterial mortality small.

Possible modifications to improve the conditions in the Morlaix Estuary included decreasing the amount of bacteria by making improvements to the Sewage treatment plant. This was not recommended. Outflows would have to be reduced by a factor of 10 to see any results in bacteria reductions near the oyster beds. The outfall location could be moved seaward. This would increase concentrations downstream by the oyster beds.

Since physical dilution acts efficiently in the estuary and mortality does not due to short transit times compared to T90, the effect of a submerged weir a few $\mathrm{km}$ downstream from the outfall was examined. This would prevent sewage material from reaching the oyster beds too quickly and would allow mortality to take place. Results are shown in Figure 2.8. Moving the outfall seemed to improve the situation in areas around the oyster beds.

\section{3. "The Relationship Between Sediment and Fecal Coliform Levels in a Puget Sound Estuary"}

Burley Lagoon, located in southern Kitsap County, Washington, was closed to commercial harvest of oysters in 1978 by the Washington State Department of Social and Health Services Shellfish Sanitation Section due to excessive levels of fecal coliform bacteria. The contamination was found to originate within Burley Lagoon's watershed and was transported by Burley Creek which flows into Burley Lagoon. Both Burley Creek and Burley Lagoon were classified as extraordinary waters and were not to exceed the following fecal coliform 
concentrations: For marine waters, 14 fecal coliform $/ 100 \mathrm{ml}$, and not more than $10 \%$ shall exceed 50 fecal coliform $/ 100 \mathrm{ml}$. For fresh water, 43 fecal coliform $/ 100$ $\mathrm{ml}$ and not more than $10 \%$ shall exceed 100 fecal coliform/100 ml.

A survey of 275 homes within the watershed revealed that 22 had failing on-site waste water systems. Repair of these systems resulted in a $15 \%$ reduction of the total load of fecal coliform in Burley Creek. Two livestock management programs were implemented to improve water quality, but Burley Creek and Burley Lagoon still remained out of compliance for fecal coliform.

Sampling results showed fecal coliform concentrations increasing by several hundred following a rainfall event. This was caused by surface runoff from failing septic system and stream side pastures. Sediment samples were found to have concentrations of fecal coliform several magnitudes higher than found in the water column at the same sampling station. The concentrations of sedimentbound fecal coliform were higher than the concentrations found in the effluent from failing septic systems.

This study was performed to investigate the relationship between stream water fecal coliform levels and the sediment fecal coliform levels and the effect during rainfall. The type and extent of growth that occurs in sediment was also examined.

The watershed area was approximately 10,000 acres consisting of 17 . percent residential and 6 percent agricultural. Most the agriculture in the area consisted of small non-commercial farms that were typically less than 10 acres and supported fewer than 10 animals. These small farms used what pasture was available, which often lead to overgrazing and excessive erosion.

Sampling sites at Minter Creek were located downstream of a densely developed area, including several small farms. Sampling sites were also located at the mouth of Burley Creek close to Burley Lagoon. The growth and survival studies used water and sediment from the mouth of Burley Creek.

The results of sediment and water column fecal coliform levels in Burley and Minter Creek are shown in Table 2.1 and Figures 2.9 through 2.14. The fecal coliform water quality standards were violated in both Burley and Minter Creek. Burley Lagoon sediment and water had lower concentrations of fecal coliform than Burley Creek. It was found that with an increase in salinity the fecal bacteria concentration decreased in the water and generally increased in the sediment. Also, peaks of fecal coliform concentrations in water lead to drops in the concentration in the sediment.

After examining five rainfall events, when it rained more than .1 inch in a 24 hour 
TABLE 2.1. Sediment and Water Column FC levels in Burley and Minter

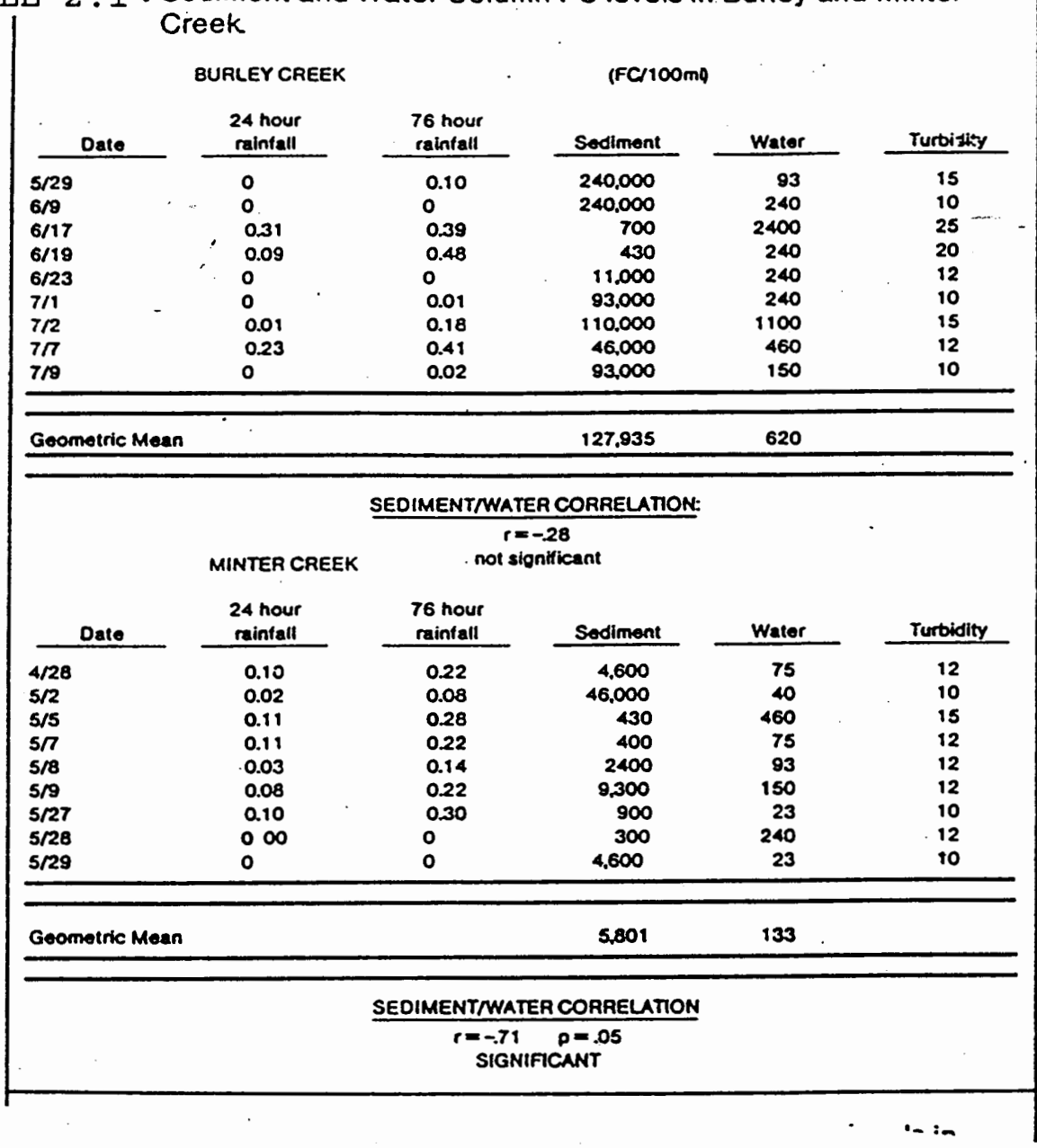

TABLE 2.2. Growth and survival of FC in selected combinations of sedi-

\begin{tabular}{|c|c|c|c|c|c|}
\hline Semple & 0 & 1 & $\begin{array}{c}\text { FFC1100 mo } \\
\text { DAY } \\
2\end{array}$ & 3 & 4 \\
\hline $\begin{array}{l}\text { "S Storide sodiment } \\
\text { Storilo Wattor } \\
1 \mathrm{mlE} \text { colic }\end{array}$ & 150 & $2.4 \times 10^{6}$ & $2.4 \times 10^{6}$ & $2.4 \times 10^{9}$ & $2.4 \times 10^{9}$ \\
\hline $\begin{array}{l}\text { 2) Non-storile sodimont } \\
\text { Stream Water } \\
1 \mathrm{ml} E \text { colt }\end{array}$ & 610 & $2.4 \times 10^{4}$ & $7.5 \times 10^{4}$ & $7.5 \times 10^{4}$ & $2.3 \times 10^{4}$ \\
\hline $\begin{array}{l}\text { 3) Storile sodiment } \\
\text { Streanwater. }\end{array}$ & 93 & $2.4 \times 10^{5}$ & $2.4 \times 10^{6}$ & $9.0 \times 10^{6}$ & $4.0 \times 10^{6}$ \\
\hline \multirow[t]{2}{*}{ FC Counts in materials: } & \multirow{2}{*}{\multicolumn{2}{|c|}{ SEDIMENT }} & - & & \\
\hline & & & WATER & & $\mathrm{COL}$ \\
\hline
\end{tabular}


FIGURE 2.9 Fecal coliform levels in Mint 3 r Creek streamwater and sediment.

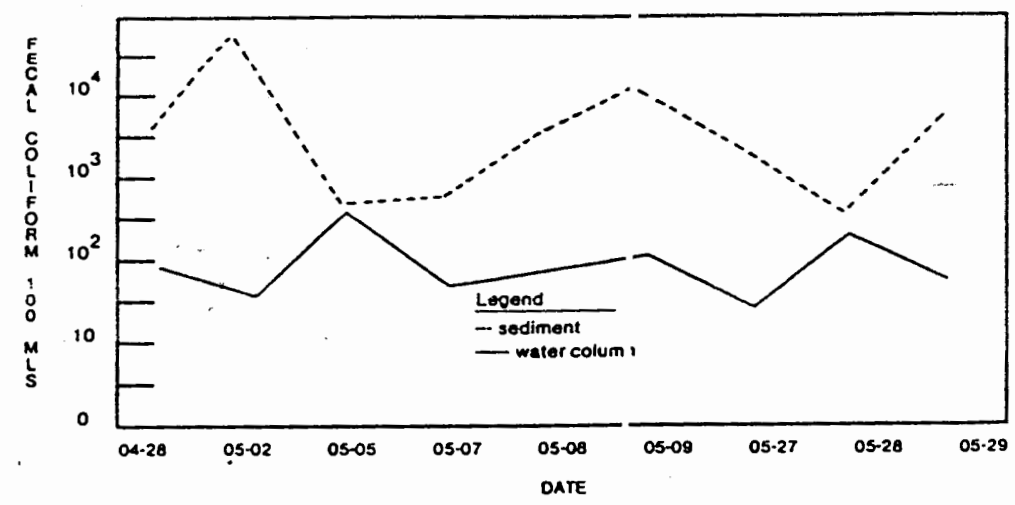

FIGURE 2.10 Minter Creek turbidity.

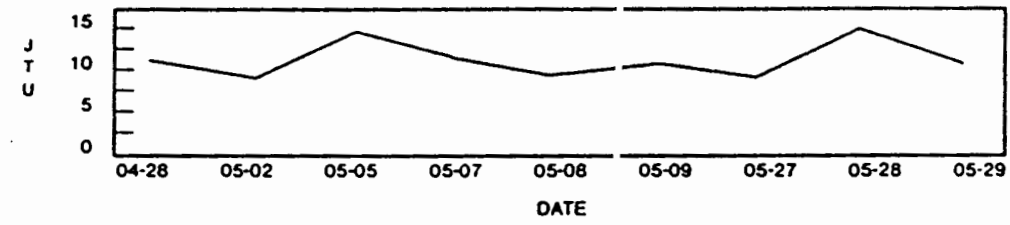

FIGURE . 2 . 11 Minter Creek rainfall.

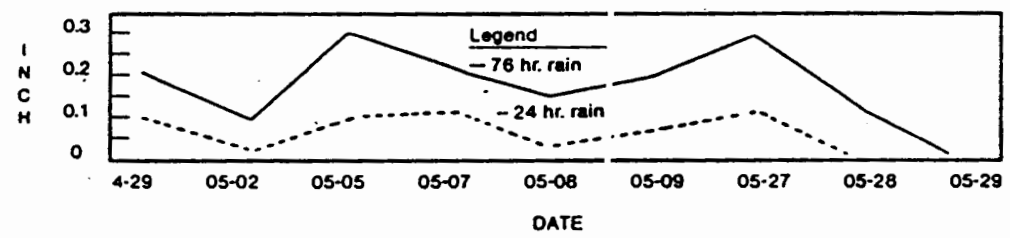

FIGURE 2.12 Fecal coliform levels in Birley Creek streamwater and sediment.

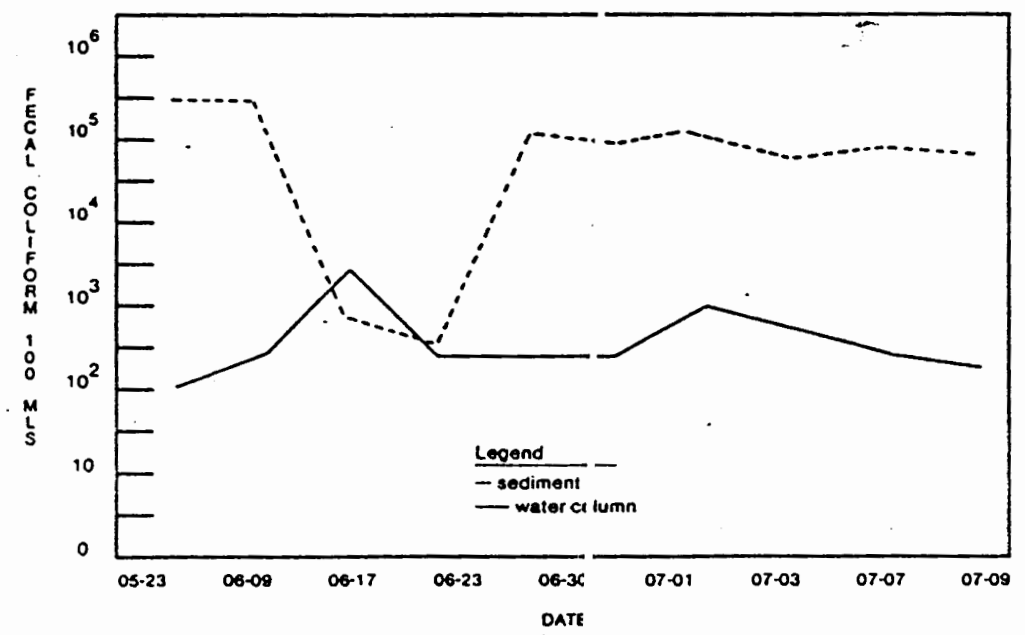


-. FIGURE 2.13 Burley Creek turbidity.

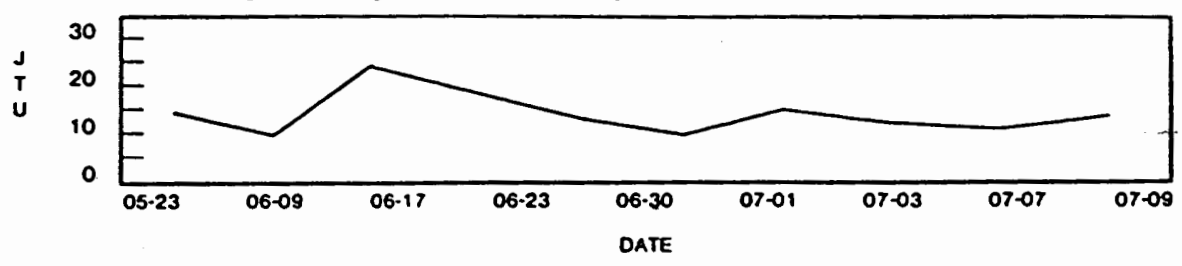

FIGURE 2.14. Burley Creek rainfall.

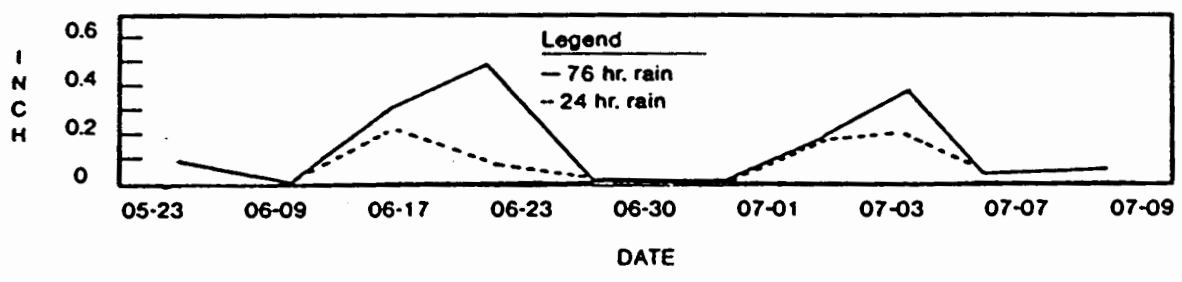

FIGURE 2.15 Growth of fecal coliform in combinations of stream water and stream sediment.

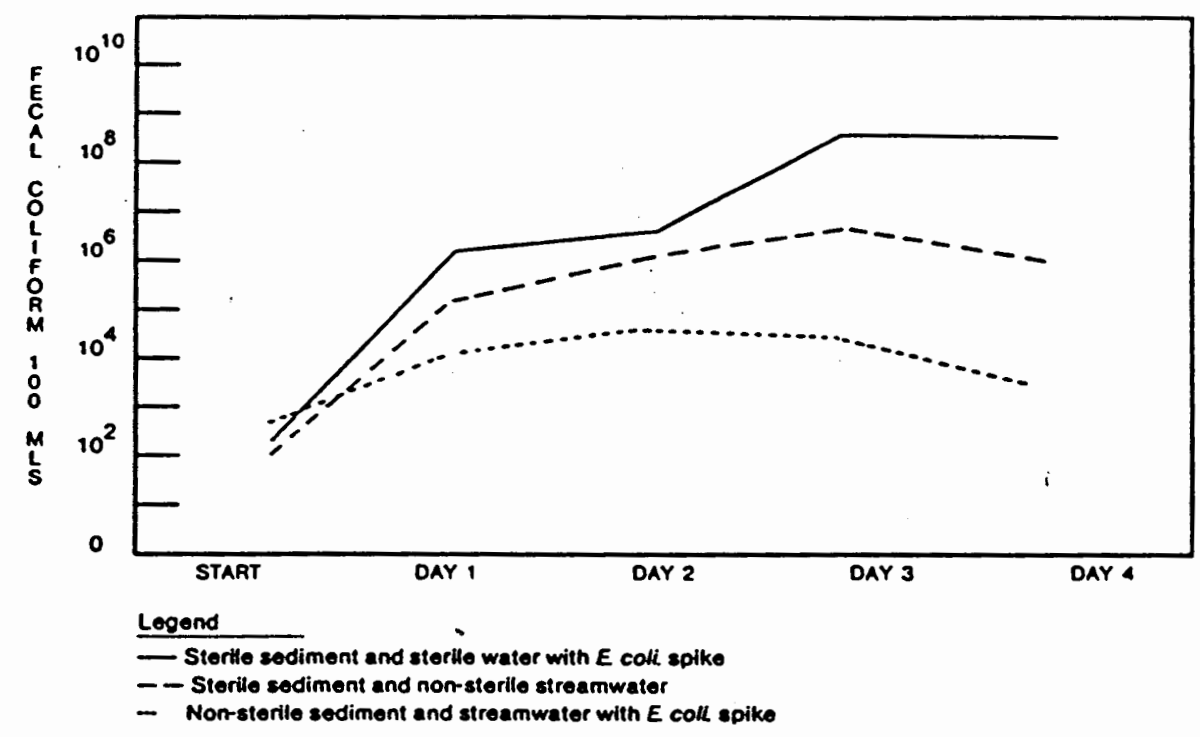


period followed by several days of dry weather, sediment bound fecal coliform were released into the water. Correlation analysis revealed that fluctuations in water fecal coliform levels could be explained by corresponding fluctuations in sediment concentrations $71 \%$ of the time.

Samples were taken to analyze the growth and survival of fecal coliform. The results are summarized in Table 2.2 and Figure 2.15. The experiment showed that fecal coliform settling into sediments were reproducing exponentially. All samples showed substantial growth. The organically rich sediment found in Burley Creek is a suitable environment for fecal coliform reproduction, but it does not appear to be self-sustaining. Fecal coliform levels remain high due to constant settling out of water from failing drain fields and livestock wastes and constant deposition of fine nutrient-rich particles.

Studies also indicated that sediments containing high fecal coliform correspond to high virus concentrations. Virus and fecal coliform survive longer in sediments and are also more easily ingested by shellfish. The author feels that "sediment sampling can be a more accurate indicator of general conditions in the watershed".

\section{4. "The Shellfish Resource in a Polluted Tidal Inlet"}

Benefits from natural resources are often overlooked. Pollution abatement could increase shellfish yield. Quantifying economic benefits of anti-pollution measures in coastal regions was difficult. The values of clean environment, ecosystem stability and aesthetic values determined in cost-benefit analyses often disagree. Direct benefits of pollution abatement can be estimated by assessing the value of the shellfish resource.

In 1981 a quantitative survey of the Annisquam River by the City of Gloucester Massachusetts to address pollution abatement benefits was completed. The intertidal flats of the Anniosquam River are shown in Figure 2.16. The river receives direct discharges of raw sewage. Many of the soft-shell clam flats had been closed to shell-fishing by Massachusetts Department of Environmental Quality Engineering due to high coliform bacterial counts greater than $700 / \mathrm{ml}$. In 1967 the City of Gloucester was ordered by the Massachusetts Division of Water Pollution Control to stop discharging untreated waste. By 1981 no sewage treatment facility existed.

Densities of clams in the flats of the Annisquam River that were closed to clamming were estimated based on survey results. The harvestable clam resource for this area for 1980 was estimated at $6 \times 10^{6}$ animals. Assuming $50-60 \%$ of these would be the actual yield, the yield was approximately $3.2 \times 10^{6}$ animals. The 


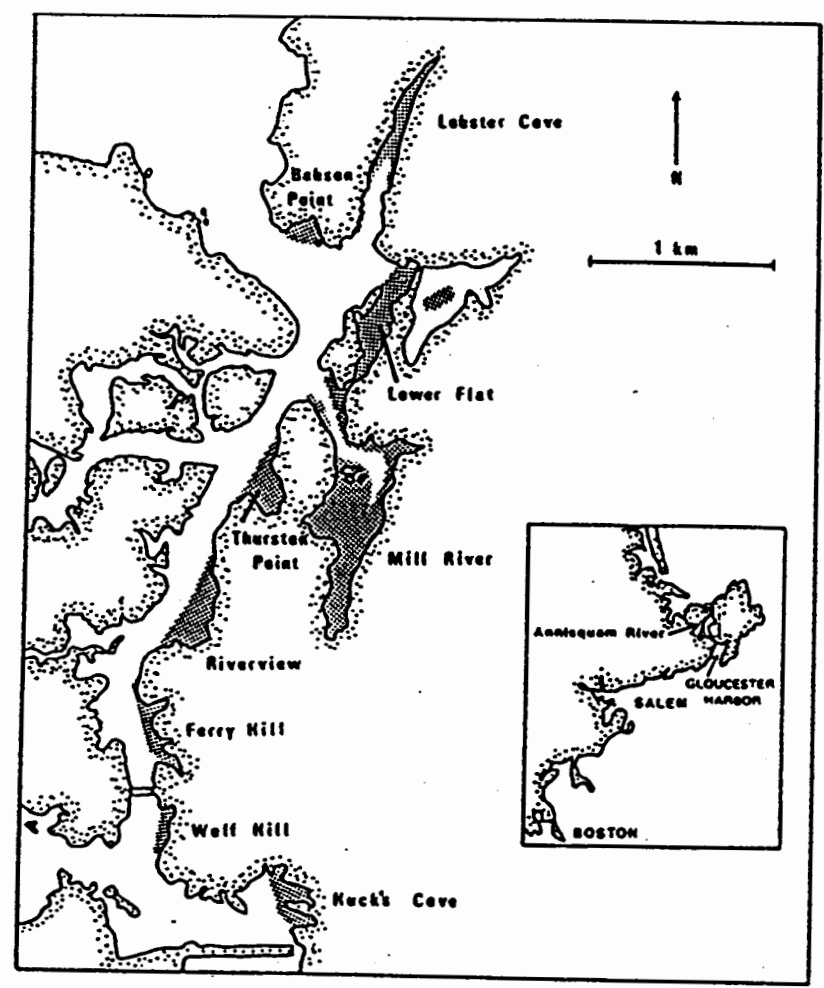

FIGURE 2.16 Intertidal flats in the Annisquam River currently closed to shell-fishing (shaded areas) because of pollution As of 1 February 1981 an additional $12 \%$ of the total clam-flat area, which is in one of the western channels not shown on the map. has been closed. Inset maplet showns general location. 
estimated retail valve of a bushel of clams (approximately 1,600 animals/bushel) in restaurants was $\$ 210$ and in the fresh trade was $\$ 64$. Restaurants buy approximately $70 \%$ and the fresh trade market buy about $30 \%$. Based on these estimates, the clam-flat closures in Gloucester community cost $\$ 332,400$ a year. This loss in income did not include the monetary benefits from the clammers and restaurant owners and employees spending their increased income within the local community. Therefore, the actual monetary impact in 1980 would have been higher.

Had the City of Gloucester taken immediate action in 1967, by 1981 the additional income from reopening of the clam-beds would have been equal to the cities share of a sewage treatment plant. In September 1979 the city applied for a waiver which would permit release of sewage after only primary treatment. This action delayed decision making and when this article was written in 1981, the community lost more than $\$ 600,000$ from the clam resource alone. Costs are based on direct short-term effects of sewage pollution. Long-term effects are also important, such as loss of recreational activities in the river and lower water front property values.

\section{CE-QUAL-W2 MODEL OVERVIEW}

\section{A Description of Model}

CE-QUAL-W2 Portland State Version is a two dimensional, (longitudinal and vertical) laterally averaged hydrodynamic and water quality model. The model predicts water surface elevations, velocities, temperature and up to 20 water quality constituents. This model allows variable heights for vertical layers, upstream or downstream head boundary conditions, time varying boundary conditions, multiple branches, multiple inflows from point or non-point sources, outflow as outlets or as lateral withdrawals, and ice-cover calculations.

The hydrodynamic and transport equations are laterally and layer averaged. Eddy coefficients are used to model turbulence. Boussinesq and hydrostatic approximations are used and the vertical momentum equation is not included. The finite difference method is used to solve the coupled partial differential equations.

\section{B Theoretical}

The CE-QUAL-W2 water quality model uses six laterally averaged equations of fluid motion: 1) horizontal momentum; 2) constituent transport; 3) free water 
surface elevation; 4) hydrostatic pressure; 5) continuity and 6) equation of state. These equations are then used to solve for six unknowns: 1) free water surface elevation, $\eta$; 2 ) pressure, $\mathbf{P}$; 3 ) horizontal velocity, $U$; 4) vertical velocity, $W$; 5) constituent concentration, $\Phi ; 6$ ) density, $\rho$. The equations are as follows:

\section{Horizontal Momentum}

$$
\frac{\partial U B}{\partial t}+\frac{\partial U U B}{\partial x}+\frac{\partial W U B}{\partial z}=-\frac{1}{\rho} \frac{\partial B P}{\partial x}+\frac{\partial\left[B A_{x} \frac{\partial U}{\partial x}\right]}{\partial x}+\frac{\partial B_{x}}{\partial z}
$$

where

$\mathrm{U}=$ longitudinal, laterally averaged velocity, $\mathrm{m} / \mathrm{sec}$

$B=$ water body width, $m$

$t=$ time, sec

$x=$ longitudinal Cartesian coordinate

$y=$ vertical Cartesian coordinate

$\mathrm{z}=$ positive downward from the $\mathrm{x}$-axis

$\mathrm{W}=$ vertical, laterally averaged velocity, $\mathrm{m} / \mathrm{sec}$

$\rho=$ density, $\mathrm{kg} / \mathrm{m}^{3}$

$\mathrm{P}=$ pressure, $\mathrm{N} / \mathrm{m}^{2}$

$A_{x}=$ longitudinal momentum dispersion coefficient, $\mathrm{m}^{2} / \mathrm{sec}^{2}$

$\tau_{x}=$ shear stress per unit mass resulting from the vertical gradient of the horizontal velocity, $\mathrm{U}, \mathrm{m}^{2} / \mathrm{sec}^{2}$

The horizontal pressure gradient in this equation evaluated at any depth $z$, where $\rho_{\eta}$ is the density at the surface is described as follows:

$$
B \frac{\partial P}{\partial x}=-\rho_{\eta} B g \frac{\partial \eta}{\partial x}+B g \int_{\eta}^{z} \frac{\partial \rho}{\partial x} d z
$$

\section{Constituent Transport}




$$
\frac{\partial B \phi}{\partial t}+\frac{\partial U B \phi}{\partial x}+\frac{\partial W B \phi}{\partial z}-\frac{\partial\left[B D_{x} \frac{\partial \phi}{\partial x}\right]}{\partial x}-\frac{\partial\left[B D_{z} \frac{\partial \phi}{\partial z}\right]}{\partial z}=q_{\phi} B+S_{k} B
$$

where
$\Phi=$ laterally averaged constituent concentration, $\mathrm{mg} / 1$
$\mathrm{D}_{\mathrm{x}}=$ longitudinal temperature and constituent dispersion coefficient, $\mathrm{m}^{2} / \mathrm{sec}$
$\mathrm{D}_{\mathrm{z}}=$ vertical temperature and constituent dispersion coefficient, $\mathrm{m}^{2} / \mathrm{sec}$
$\mathrm{q}_{\Phi}=$ lateral inflow or outflow mass flow rate of constituent per unit volume, $\mathrm{mg} / 1 / \mathrm{sec}$
$S_{k}=$ kinetics source/sink term for constituent concentrations

Free Water Surface Elevation

$$
\frac{\partial B_{\eta} \eta}{\partial t}=\frac{\partial}{\partial x} \int_{\eta}^{h} U B d z-\int_{\eta}^{h} q B d z
$$

where

$$
\begin{aligned}
& B_{\eta}=\text { time and spatially varying surface width, } m \\
& \eta=\text { free water surface location, } m \\
& h=\text { total depth, } m \\
& q=\text { lateral boundary inflow or outflow, } \mathrm{m}^{3} / \mathrm{sec}
\end{aligned}
$$

The vertical integral of the horizontal flow was determined using forward time difference of the local acceleration of horizontal momentum in Equation 1. After further mathematical evaluation, the final results for the surface elevation is as follows:

$$
\begin{gathered}
\frac{\partial \bar{B} \eta}{\partial t}-g \Delta t \frac{\partial}{\partial x}\left[\frac{\partial \eta}{\partial x} \int_{\eta}^{h} B d z\right]=\frac{\partial}{\partial x} \int_{\eta}^{h} U B d z-\frac{g \Delta t}{\rho_{\eta}} \frac{\partial}{\partial x} \int_{\eta}^{h}\left[B \int_{\eta}^{z} \frac{\partial \rho}{\partial x} d z\right] d z \\
+\frac{\partial}{\partial x}\left[B_{h} \tau_{h}-B_{\eta} \tau_{\eta}-\int_{\eta}^{h} \tau_{x} \frac{\partial B}{\partial Z} d Z\right] \Delta t+\frac{\partial}{\partial x}\left[\int_{\eta}^{h} F d z\right] \Delta t-\left[\int_{\eta}^{h} q B d z\right]
\end{gathered}
$$


Hydrostatic Pressure

$$
F_{X}=\frac{\partial\left(B A_{X} \frac{\partial U}{\partial X}\right)}{\partial X}-\frac{\partial U U B}{\partial X}-\frac{\partial W U B}{\partial z}
$$

$$
\frac{\partial P}{\partial z}=08
$$

where

$$
\mathrm{g}=\text { acceleration due to gravity, } \mathrm{m} / \mathrm{sec}^{2}
$$

\section{Continuity}

$$
\frac{\partial U B}{\partial x}+\frac{\partial W B}{\partial z}=q B
$$

\section{Equation of State}

$$
Q=f(\phi)
$$

where

$$
f(\Phi)=\quad \text { function for density that is dependent upon temperature, }
$$
total dissolved solids or salinity, and suspended solids

For a more complete description of these equations, see the CE-QUAL-W2 Users Manual (Cole, T., and Buchek, E., 1994; Corps of Engineers (1986)). 


\section{SOUTH SLOUGH MODEL}

\section{A Setup}

To model the South Slough the following information was required:

1. Bathymetry of South Slough, longitudinal and vertical cell widths

2. Flow from contributing watersheds

3. Temperature and concentration data from contributing watersheds

4. Water surface elevations at Charleston Harbor, the downstream boundary condition

5. Temperature and concentration data at Charleston Harbor

6. Meteorological data: air temperature, dew point, wind speed, wind direction and cloud cover

\section{B Inputs}

\section{Model Geometry}

To model the South Slough estuary, the slough was divided into two branches, the main branch from Talbot and John B Creeks to Charleston Harbor, and the second branch from Winchester Creek to Valino Island. Each branch was broken into longitudinal cells 400 feet $(121.92 \mathrm{~m})$ long. The upstream segment of the main branch is cell two and the downstream end at Charleston Harbor is cell 61. Branch two begins at cell 64 and ends at cell 93. CE-QUAL-W2 requires inactive cells at the beginning and end of each branch. The inactive cells for the South Slough model are cells 1,62,63, and 94. Figure 4.1 is a schematic of the cell layout for the South Slough Model.

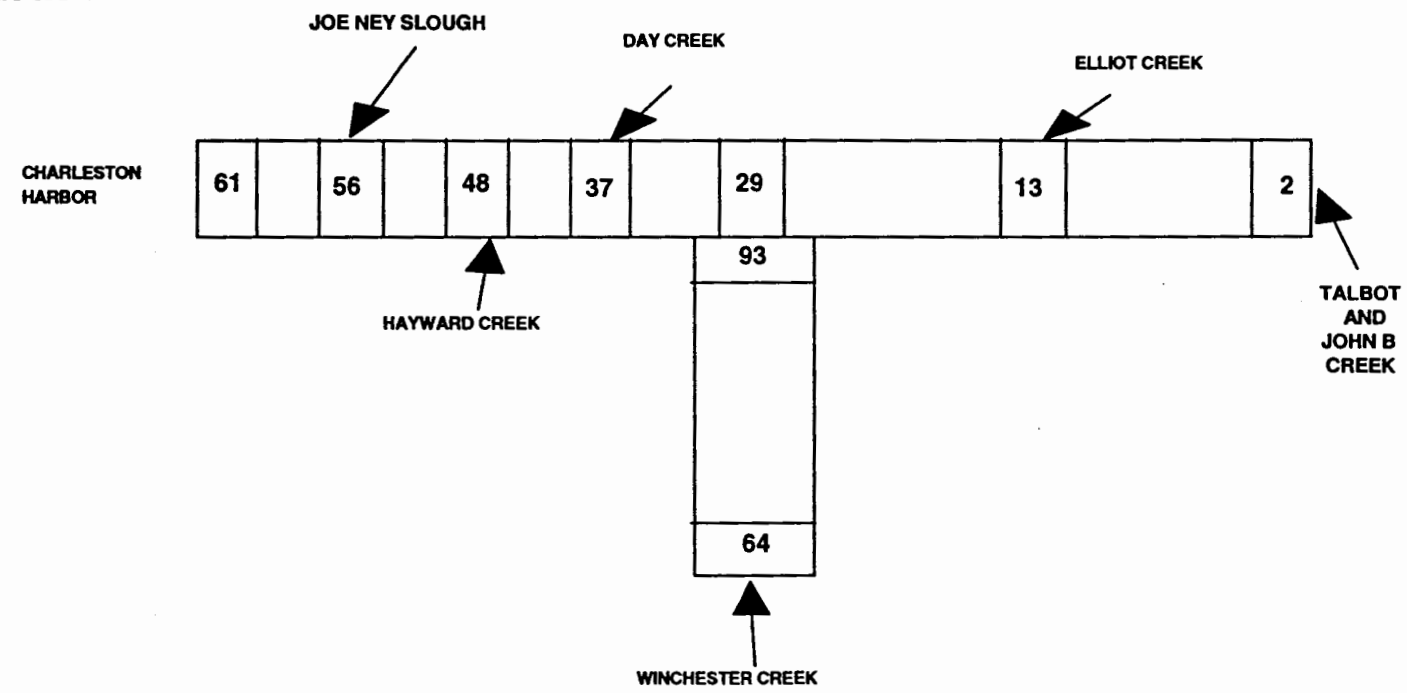

FIGURE 4.1 Cell Geometry For South Slough Model 
The bathymetry of South Slough was obtained from Wells and Baird (1990). The elevation data were approximate because the original survey did not specify a NGVD vertical datum. The model vertical grid datum was varied in later model simulations. The deepest area was approximately $-18 \mathrm{ft}$ NGVD (-5.49 m NGVD). Each vertical cell of the model was divided into two foot elevations from $1.83 \mathrm{~m}$ to -5.49 NGVD, for a total of 14 vertical layers. The model was originally setup with 13 layers but was increased to 14 layers during the calibration process. The depth for each cell is shown in Figure 4.2. The width of each cell at each elevation layer was also obtained from Wells and Baird (1991). Branch 1 model cells are shown in Table 4.1 and branch 2 model cells are shown in Table 4.2. Figure 4.3 and 4.4 are topographic maps of the South Slough Estuary with the cell designations also shown for branch 1 and branch 2, respectively. 


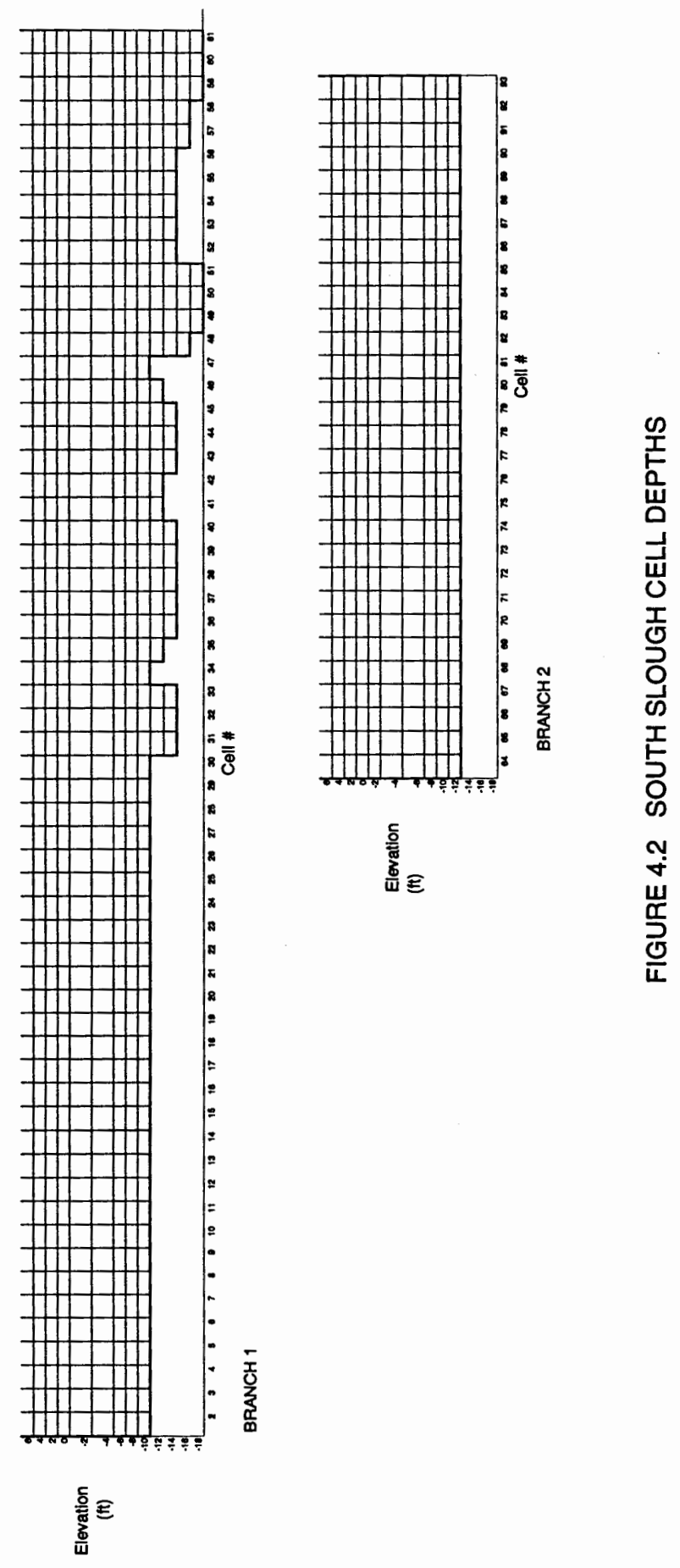




\begin{tabular}{|c|c|c|c|c|c|c|c|c|c|c|c|c|}
\hline \multirow[b]{2}{*}{ Cell \# } & \multirow{2}{*}{\begin{tabular}{|l|} 
Layer \\
$\#$
\end{tabular}} & \multirow{2}{*}{$\begin{array}{l}\text { Elev. of } \\
\text { Cell, (m) }\end{array}$} & \multicolumn{10}{|c|}{ Cell Width (M) } \\
\hline & & & 1 & 2 & 3 & 4 & 5 & 6 & 7 & 8 & 9 & 10 \\
\hline & 1 & 2.44 & 이 & o] & 0 & o) & 이 & 0 & 0) & 0 & 요 & 0 \\
\hline & 2 & 1.83 & 의 & 352.1 & 664.2 & 2500 & 861.5 & 1719 & 1061 & 771.7 & 628.2 & 483.6 \\
\hline & 3 & 1.2 & of & 320.1 & 603.8 & 2273 & 783.2 & 1562 & 964.5 & 701.5 & 571.1 & -439.6 \\
\hline & 4 & 0.61 & of & 207.4 & 398.8 & 1315 & 529.8 & 1044 & 776.7 & 493.9 & 418.5 & 327.2 \\
\hline & 5 & 0 & of & 94.6 & 193.9 & 356.7 & 276.4 & 525.5 & 531.3 & 386.3 & 266 & 214.7 \\
\hline & 6 & -.61 & 0) & 10.5 & 15.5 & 25.5 & 66.5 & 120 & 326.8 & 155.7 & 113.5 & 101.1 \\
\hline & 7 & -1.22 & 0 & 9.5 & 12 & 19 & 19 & 29.5 & 29 & 29 & 29 & 38.5 \\
\hline & 8 & -1.83 & 0 & 4 & 4 & 4 & 4 & 4 & 4 & 4 & 4 & 4 \\
\hline & 9 & -2.44 & 0] & 3 & 3 & 3 & 3 & 3 & 3 & 3 & 3 & 3 \\
\hline & 10 & -3.05 & 0 & 3 & 3 & 3 & 3 & 3 & 3 & 3 & 3 & 3 \\
\hline & 11 & -3.66 & 0 & 0 & o) & 0 & 0 & 0 & 0 & 0 & 0 & 0 \\
\hline & 12 & -4.27 & of & 0 & of & 0 & 0 & 0 & 0 & 0 & 0 & 0 \\
\hline & 13 & -4.88 & 의 & of & of & - & 이 & 이 & 0 & 0 & 0 & 0 \\
\hline & 14 & -5.49 & 0] & 0 & 0 & 이 & 01 & 이 & 이 & 0 & 0 & 0 \\
\hline
\end{tabular}

\begin{tabular}{|c|c|c|c|c|c|c|c|c|c|c|c|c|}
\hline \multirow[b]{2}{*}{ Cell \# } & \multirow{2}{*}{ Layer \# } & \multirow{2}{*}{$\begin{array}{l}\text { Elev. of } \\
\text { Cell, }(m)\end{array}$} & \multicolumn{10}{|c|}{ Cell Width $(M)$} \\
\hline & & & 11 & 12 & 13 & 14 & 15 & 16 & 17) & 18 & 19 & 20 \\
\hline & 1 & 2.44 & of & o) & 요 & 요 & 아 & 요 & 요 & 의 & 요 & 0 \\
\hline & 2 & 1.83 & 292.2 & 427.7 & 826.5 & 772.6 & 756.3 & 1004 & 814.4 & 1432 & 4098 & 1083 \\
\hline & 3 & 1.2 & 265.6 & 388.8 & 751.4 & 702.4 & 687.5 & 912.3 & 740.4 & 1301 & 3725 & 984.8 \\
\hline & 4 & 0.61 & 221.2 & 334.7 & 618.7 & 521.2 & 521.2 & 673.4 & 595.1 & 901.7 & 2247 & 770.4 \\
\hline & 5 & 0 & 176.8 & 280.6 & 486 & 340 & 354.8 & 434.4 & 449.7 & 502.1 & 769.5 & 556.1 \\
\hline & 6 & -.61 & 132.5 & 222.3 & 364.2 & 193.6 & 190.4 & 254.2 & 303.1 & 270.2 & 303.8 & 308.1 \\
\hline & 7 & -1.22 & 70.6 & 52.7 & 186.7 & 125.3 & 113.7 & 148 & 147.1 & 207.6 & 196.9 & 179.4 \\
\hline & 8 & -1.83 & 4 & 14 & 52.4 & 15 & 52.4 & 20 & 73.1 & 88.8 & 85.9 & 87.9 \\
\hline & 9 & -2.44 & 3 & 3 & 3 & 3 & 3 & 3 & 3 & 3 & 3 & 3 \\
\hline & 10 & -3.05 & 3 & 3 & 3 & 3 & 3 & 3 & 3 & 3 & 3 & 3 \\
\hline & 11 & -3.66 & 0) & 0 & 0 & 0 & 0 & 이 & 이 & 이 & 0 & 0 \\
\hline & 12 & -4.27 & 의 & 0 & 0 & 0 & 0 & 0 & 0 & 0 & 0 & 0 \\
\hline & 13 & -4.88 & 의 & 이 & 0 & - & 0 & 0 & 0 & 0 & 0 & 0 \\
\hline & 14 & -5.49 & 요 & 이 & 이 & 0 & 0 & 이 & 이 & 이 & 0 & 0 \\
\hline
\end{tabular}

TABLE 4.1 South Slough Model Cell Widths Branch 1 


\begin{tabular}{|c|c|c|c|c|c|c|c|c|c|c|c|c|}
\hline \multirow[b]{2}{*}{ Cell \# } & \multirow{2}{*}{ Layer \# } & \multirow{2}{*}{$\begin{array}{l}\text { Elev. of } \\
\text { Cell, (m) }\end{array}$} & \multicolumn{10}{|c|}{ Cell Width (M) } \\
\hline & & & 21) & 22 & 23 & 24 & 25 & 26 & 27 & 28 & 29 & 30 \\
\hline & 1 & 2.44 & o & o] & 0 & 이 & 요 & 0 & 요 & 의 & 요 & 0 \\
\hline & 2 & 1.83 & 616.8 & 833.5 & 921.8 & 961 & 2288 & 1314 & 1527 & 940.3 & 818.1 & 889.2 \\
\hline & 3 & 12 & 560.7 & 757.7 & 838 & 873.6 & 2080 & 1194 & 1388 & 854.8 & 743.7 & 808.4 \\
\hline & 4 & 0.61 & 486.7 & 591.9 & 683.5 & 718 & 1704 & 1093 & 1244 & 715.2 & 624 & 598.9 \\
\hline & 5 & 0 & 412.7 & 426.1 & 528.9 & 562.3 & 1328 & 991.9 & 1100 & 575.7 & 504.3 & 389.4 \\
\hline & 6 & -0.61 & 282.1 & 264.4 & 318.9 & 405.1 & 500.2 & 890.6 & 955.1 & 436.1 & 384.6 & 245.4 \\
\hline & 7 & -1.22 & 165.2 & 118.8 & 147.9 & 202.7 & 189.5 & 186.1 & 156.1 & 303.7 & 268 & 170 \\
\hline & 8 & -1.83 & 79.5 & 55.1 & 68.3 & 101.3 & 20 & 20 & 20 & 178.4 & 167.5 & 74.3 \\
\hline & 9 & -2.44 & 3 & 5 & 9 & 31.1 & 9 & 8 & 9 & 63.2 & 43.2. & 55 \\
\hline & 10 & -3.05 & 3 & 3 & 3 & 3 & 3) & 3 & 5 & 9 & 10 & 18 \\
\hline & 11 & -3.66 & of & 0 & 이 & o & 0] & 0 & - & 0 & 0 & 0 \\
\hline & 12 & -4.27 & 0 & o) & 이 & 요 & 이 & 0 & 0) & 이 & o & 0 \\
\hline & 13 & -4.88 & 0] & 0 & 0) & 0) & 의 & 0 & 이 & 이 & 의 & 0 \\
\hline & 14 & -5.49 & 0 & 0 & 0 & 이 & 이 & 0 & 이 & o) & o) & 0 \\
\hline
\end{tabular}

\begin{tabular}{|c|c|c|c|c|c|c|c|c|c|c|c|c|}
\hline \multirow[b]{2}{*}{ Cell \# } & \multirow{2}{*}{ Layer \# } & \multirow{2}{*}{$\begin{array}{l}\text { Elev. of } \\
\text { Cell, (m) }\end{array}$} & \multicolumn{10}{|c|}{ Cell Width (M) } \\
\hline & & & 31 & 32 & 33 & 34 & 35 & 36 & 37 & 38 & 39 & 40 \\
\hline & 1 & 2.44 & 0 & 0 & 이 & 0 & 0 & 0 & 이 & 0 & 0 & 0 \\
\hline & 2 & 1.83 & 883.9 & 794.8 & 649.9 & 521.4 & 2868 & 1377 & 680.9 & 916.9 & 583.3 & 638.5 \\
\hline & 3 & 1.2 & 803.5 & 722.5 & 590.8 & 474 & 2607 & 1252 & 619 & 833.5 & 530.3 & 580.5 \\
\hline & 4 & 0.61 & 660.7 & 624.9 & 527.5 & 435.5 & 1741 & 1108 & 552.9 & 661.1 & 490.8 & 526.8 \\
\hline & 5 & 0 & 517.9 & 527.4 & 464.2 & 397 & 875.2 & 963.8 & 486.8 & 488.6 & 451.3 & 473.2 \\
\hline & 6 & -.61 & 375.2 & 429.8 & 401 & 358.6 & 336.8 & 675.7 & 420.6 & 365.4 & 411.8 & 419.6 \\
\hline & 7 & -1.22 & 284.6 & 342.4 & 336.7 & 320.1 & 290.4 & 246.4 & 177 & 338.3 & 364.8 & 341.8 \\
\hline & 8 & -1.83 & 150.6 & 142.7 & 228.5 & 181 & 133.1 & 139.4 & 138.5 & 146.4 & 278.6 & 194.6 \\
\hline & 9 & -2.44 & 95.4 & 95.1 & 96.2 & 106.2 & 76.5 & 98.1 & 109 & 103.2 & 126.2 & 130.2 \\
\hline & 10 & -3.05 & 41.4 & 56.8 & 5 & 0 & 20 & 56.8 & 69.3 & 42.3 & 79.2 & 83.6 \\
\hline & 11 & -3.66 & 2 & 11 & 2 & 0 & 0 & 5.7 & 5 & 5 & 5 & 14.7 \\
\hline & 12 & -4.27 & 0 & 0 & of & 0 & 0 & 0 & 0 & 0 & 0 & 0 \\
\hline & 13 & -4.88 & 0 & 0 & of & 0 & 의 & 0 & 0 & 0 & 0 & 0 \\
\hline & 14) & -5.49 & 0 & 0 & o) & 0 & 0 & 0 & 0 & 0 & 0 & 0 \\
\hline
\end{tabular}

TABLE 4.1 (CONT.) South Slough Model Cell Widths Branch 1 


\begin{tabular}{|c|c|c|c|c|c|c|c|c|c|c|c|c|}
\hline \multirow[b]{2}{*}{ Cell \# } & \multirow{2}{*}{ Layer \# } & \multirow{2}{*}{$\begin{array}{l}\text { Elev. of } \\
\text { Cell, (m) }\end{array}$} & \multicolumn{10}{|c|}{ Cell Width (M) } \\
\hline & & & 41 & 42 & 43 & 44 & 45 & 46 & 47 & 48 & 49 & 50 \\
\hline & 11 & 2.44 & o) & 0 & of & of & 0) & 이 & 요 & 의 & 0 & 0 \\
\hline & 2 & 1.83 & 874 & 1129 & 1457 & 1421 & 1068 & 1025 & 1229 & 1383 & 1056 & 2249 \\
\hline & 3 & 1.2 & 794.5 & 1026 & 1324 & 1292 & 970.8 & 932.1 & 1118 & 1258 & 960 & 2044 \\
\hline & 4 & 0.61 & 678.1 & 822.9 & 1116 & 1141 & 850.7 & 831.8 & 960.7 & 1122 & 959.9 & 1477 \\
\hline & 5 & 0 & 561.7 & 619.6 & 907.4 & 990.2 & 730.7 & 731.5 & 803.8 & 987 & 959.7 & 909.4 \\
\hline & 6 & -0.61 & 443 & 460.2 & 459.9 & 864.1 & 636.2 & 630.6 & 633.5 & 845.4 & 825.2 & 660.8 \\
\hline & 7 & -1.22 & 331.7 & 285.3 & 370.2 & 559.8 & 338.1 & 348.9 & 367.5 & 407 & 349.6 & 335.6 \\
\hline & 8 & -1.83 & 192.2 & 231.8 & 260.5 & 280.2 & 290.5 & 266.5 & 262 & 226.5 & 180.9 & 159.2 \\
\hline & 9 & -2.44 & 144.6 & 185.8 & 183.6 & 237.5 & 247 & 203.5 & 190.5 & 157.8 & 136.2 & 128.9 \\
\hline & 10 & -3.05 & 90.7 & 138.3 & 114.7 & 97 & 78.4 & 136 & 0 & 112.2 & 103.5 & 100.2 \\
\hline & 11 & -3.66 & 0 & 0 & 45.5 & 47.9 & 5 & 0 & 0 & 74.3 & 75.1 & 76.3 \\
\hline & 12 & -4.27 & 0 & 0 & 0 & 0 & of & 0) & 0 & 26.9 & 45 & 52.5 \\
\hline & 13 & -4.88 & 0 & of & o) & 0 & 0 & 0 & 0 & 0 & 5 & 22.8 \\
\hline & 14 & -5.49 & 0] & 0] & 01 & $0]$ & 0] & 0 & 0 & 0 & of & 0 \\
\hline
\end{tabular}

\begin{tabular}{|c|c|c|c|c|c|c|c|c|c|c|c|c|c|}
\hline & & & & & & & Eell Widtl & $(M)$ & & & & & \\
\hline $\begin{array}{l}\text { Cell } \\
\#\end{array}$ & & & 51 & 52 & 53 & 54) & 55 & 56 & 57 & 58 & 59 & 60 & 61 \\
\hline & 1 & 2.44 & 0 & 0 & 요 & 이 & 0 & 의 & of & 이 & 이 & 이 & 0 \\
\hline & 2 & 1.83 & 978.5 & 982.6 & 920.8 & 905.3 & 1409 & 1182 & 1819 & 1046 & 939.6 & 841.6 & 450 \\
\hline & 3 & 12 & 889.5 & 893.3 & 837.1 & 823 & 1281 & 1075 & 1653 & 951.1 & 854.2 & 765.1 & 345 \\
\hline & 4 & 0.61 & 835.7 & 807.6 & 769.5 & 771.3 & 1026 & 1004 & 1214 & 817.1 & 734 & 649.2 & 325 \\
\hline & 5 & 0 & 781.9 & 721.8 & 701.9 & 719.6 & 771.3 & 933.6 & 775.4 & 683.1 & 613.8 & 533.2 & 255 \\
\hline & 6 & -0.61 & 638.9 & 634 & 634.3 & 655.9 & 687.6 & 868.9 & 526.2 & 532.2 & 488 & 417.2 & 200 \\
\hline & 7 & -1.22 & 346.9 & 534 & 328.3 & 333.9 & 392 & 411 & 368.1 & 326.7 & 309.9 & 253.4 & 150 \\
\hline & 8 & -1.83 & 305.7 & 329.1 & 264.4 & 264.9 & 292.4 & 305.1 & 288 & 272.6 & 258.6 & 220.9 & 125 \\
\hline & 9 & -2.44 & 152.7 & 274.9 & 218.5 & 213.5 & 216.6 & 243.7 & 236.4 & 231.3 & 221.6 & 192.1 & 103 \\
\hline & 10 & -3.05 & 111.3 & 128 & 164.7 & 162 & 161.4 & 174.1 & 194.6 & 192.8 & 185.9 & 163.5 & 92 \\
\hline & 11 & -3.66 & 81.9 & 42.7 & 34.2 & 36 & 123.2 & 102.6 & 152.5 & 149.6 & 146.3 & 126.9 & 81 \\
\hline & 12 & -4.27 & 51.2 & 0 & 0 & 0 & 0 & 0 & 91.8 & 94.1 & 91.1 & 89.7 & 50 \\
\hline & 13 & -4.88 & 5.7 & 0 & 0 & o) & 0 & of & 0 & 0 & 10 & 15 & 20 \\
\hline & 14 & -5.49 & $0]$ & 01 & of & 이 & o) & 0 & 0 & 0 & 0 & 0 & 0 \\
\hline
\end{tabular}

TABLE 4.1 (CONT.) South Slough Model Cell Widths Branch 1 


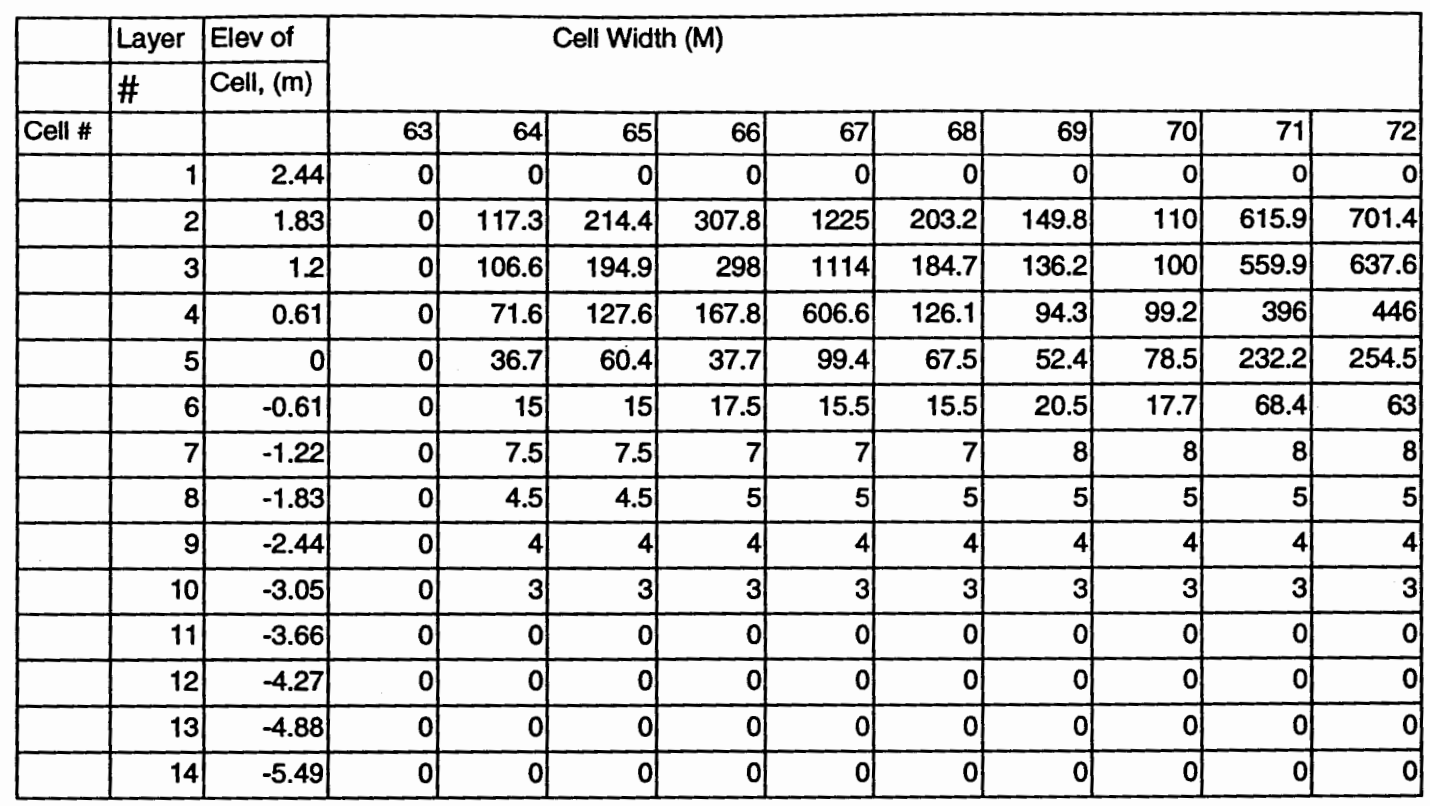

\begin{tabular}{|c|c|c|c|c|c|c|c|c|c|c|c|c|}
\hline & \multirow{2}{*}{$\begin{array}{l}\text { Layer } \\
\#\end{array}$} & \multirow{2}{*}{\begin{tabular}{|l|} 
Elev of \\
Cell, $(m)$ \\
\end{tabular}} & \multicolumn{10}{|c|}{ Cell Width (M) } \\
\hline & & & & & & & & & & & & \\
\hline \multirow[t]{15}{*}{ Cell \# } & & & 73 & 74 & 75 & 76 & 77 & 78 & 79 & 80 & 81 & 82 \\
\hline & 1 & 2.44 & 0 & 0 & 0 & o) & 0 & 이 & 0 & 0 & 0 & 0 \\
\hline & 2 & 1.83 & 271.9 & 434 & 380.3 & 865.3 & 806.2 & 597.4 & 909 & 677.3 & 1645 & 470.1 \\
\hline & 3 & 1.2 & 247.2 & 394.5 & 345.7 & 786.6 & 732.9 & 543.1 & 826.4 & 615.7 & 1495 & 427.4 \\
\hline & 4 & 0.61 & 195 & 308.7 & 274.1 & 564.9 & 542.8 & 454.9 & 608.3 & 492.6 & 1128 & 394.5 \\
\hline & 5 & 이 & 142.8 & 222.9 & 202.5 & 343.1 & 352.8 & 366.7 & 390.1 & 369.5 & 760.9 & 361.5 \\
\hline & 6 & -0.61 & 90.6 & 93.6 & 129.7 & 114.1 & 206.9 & 214.1 & 286.6 & 246.4 & 222.4 & 159.8 \\
\hline & 7 & -1.22 & 22.7 & 15 & 39.1 & 27.9 & 26.5 & 75.5 & 25 & 38.8 & 77.1 & 115.8 \\
\hline & 8 & -1.83 & 5 & 5 & 5 & 5 & 5 & 5 & 5 & 5 & 7.6 & 16.7 \\
\hline & 9 & -2.44 & 4 & 4 & 4) & 4 & 4) & 4 & 4 & 4 & 4 & 4 \\
\hline & 10 & -3.05 & 3 & 3 & 3 & 3 & 3 & 3 & 3 & 3 & 3 & 3 \\
\hline & 11 & -3.66 & 0 & 0 & 0 & of & 이 & 0 & 0 & 0 & 0) & 0 \\
\hline & 12 & -4.27 & 0 & 0 & o) & o) & 0 & 이 & 이 & 0 & 0) & 0 \\
\hline & 13 & -4.88 & 0 & o & of & 0 & 0 & 0 & 0 & 0 & 0 & 0 \\
\hline & 14 & -5.49 & o) & 0 & 0 & 0 & 0 & 0 & 0 & 0 & 0 & 0 \\
\hline
\end{tabular}

TABLE 4.2 South Slough Model Cell Widths Branch 2 


\begin{tabular}{|c|c|c|c|c|c|c|c|c|c|c|c|c|c|}
\hline & \multirow{2}{*}{$\begin{array}{l}\text { Layer } \\
\#\end{array}$} & \multirow{2}{*}{\begin{tabular}{|l|} 
Elev of \\
Cell, $(m)$ \\
\end{tabular}} & \multicolumn{11}{|c|}{ Cell Width (M) } \\
\hline & & & & & & & & & & & & & \\
\hline \multirow[t]{15}{*}{ Cell \# } & & & 83 & 84 & 85 & 86 & 87 & 88 & 89 & 90 & 91 & 92 & 93 \\
\hline & 1 & 2.44 & 0 & 0 & 0 & 0 & 0 & 0 & 0 & 0 & 0 & 0 & 0 \\
\hline & 2 & 1.83 & 761.1 & 574.2 & 1209 & 1082 & 736.9 & 539.5 & 473.6 & 4230 & 714.5 & 705.8 & 817.9 \\
\hline & 3 & 1.2 & 691.9 & 522 & 1099 & 984 & 669.9 & 490.5 & 430.5 & 3845 & 649.5 & 641.6 & 743.5 \\
\hline & 4 & 0.61 & 530.8 & 418.1 & 779.7 & 721.3 & 555.2 & 431.6 & 384.9 & 2396 & 558.4 & 546.8 & 603.2 \\
\hline & 5 & 0 & 369.7 & 314.2 & 460.7 & 458.7 & 440.4 & 372.7 & 339.4 & 946.5 & 467.3 & 452.1 & 462.8 \\
\hline & 6 & -0.61 & 161.9 & 217.5 & 236.7 & 270.7 & 329.2 & 167.2 & 205.2 & 305.6 & 362.9 & 359 & 340.8 \\
\hline & 7 & -1.22 & 117.3 & 107.4 & 111.7 & 99.9 & 90.7 & 103.4 & 122.6 & 116.7 & 96.2 & 89.3 & 156.1 \\
\hline & 8 & -1.83 & 59.6 & 70.9 & 71.7 & 39.5 & 33.7 & 45.2 & 58.6 & 71.3 & 44.2 & 15 & 61.3 \\
\hline & 9 & -2.44 & 9 & 24.6 & 22.4 & 6 & 5 & 5 & 5 & 5 & 5 & 5 & 5 \\
\hline & 10 & -3.05 & 3 & 3 & 3 & 3 & 3 & 3 & 3 & 3 & 3 & 3 & 3 \\
\hline & 11 & -3.66 & 이 & 0 & 0 & 0 & 0 & 이 & 0 & 0 & 0 & 이 & 0 \\
\hline & 12 & -4.27 & 0 & 0 & 0 & 0 & 0 & 0 & 0 & 0 & 0 & 0 & 0 \\
\hline & 13 & -4.88 & 0 & 0 & 0 & 0 & 0 & 0 & 0 & 0 & 0 & 0 & 0 \\
\hline & 14 & -5.49 & 이 & 0 & 이 & 0 & 이 & 0 & 이 & 0 & 이 & 0 & 0 \\
\hline
\end{tabular}

TABLE 4.2 (CONT.) South Slough Model Cell Widths Branch 2 

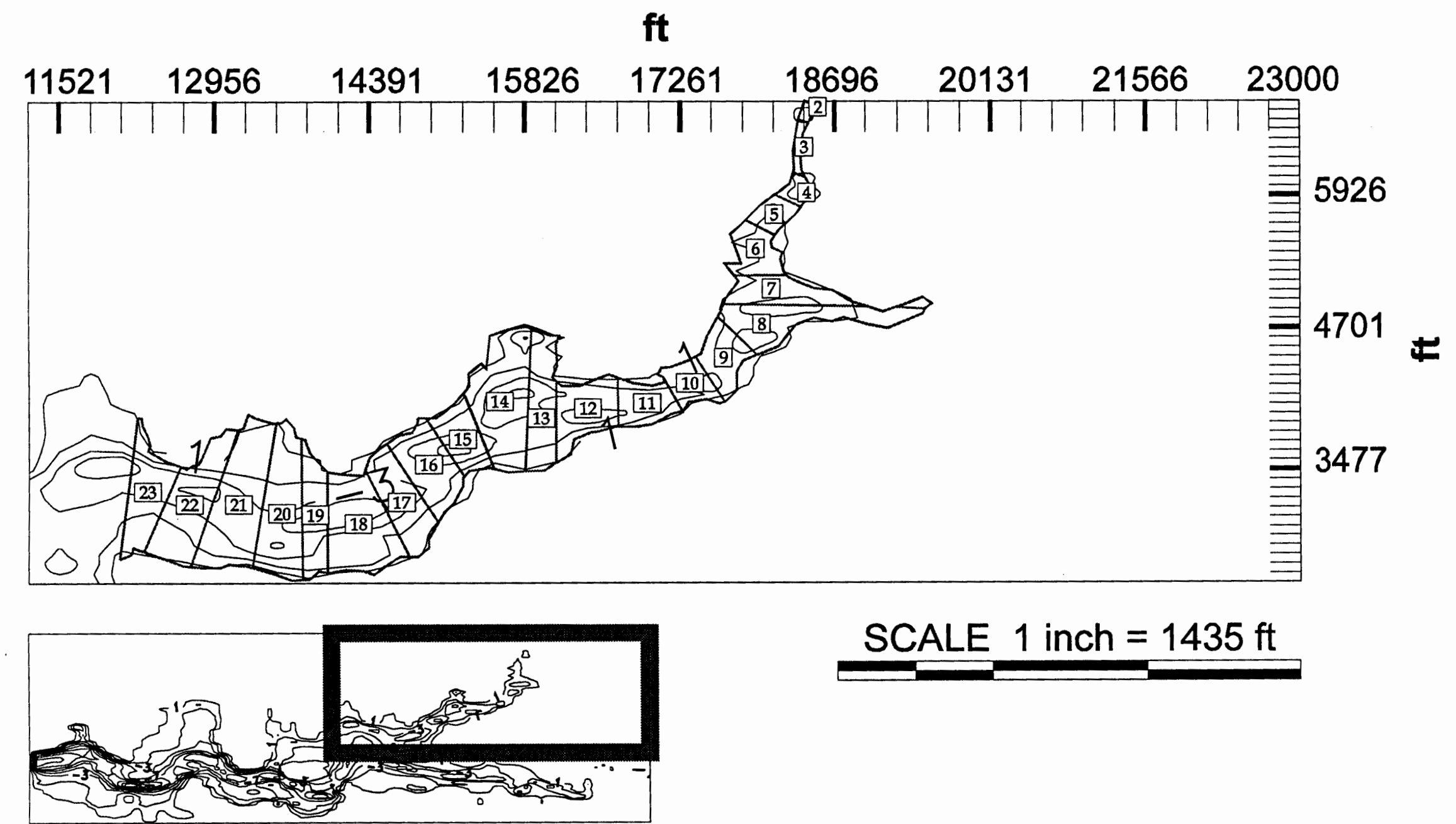

SCALE 1 inch $=1435 \mathrm{ft}$

FIGURE 4.3 Topography For South Slough Estuary, Branch 1 


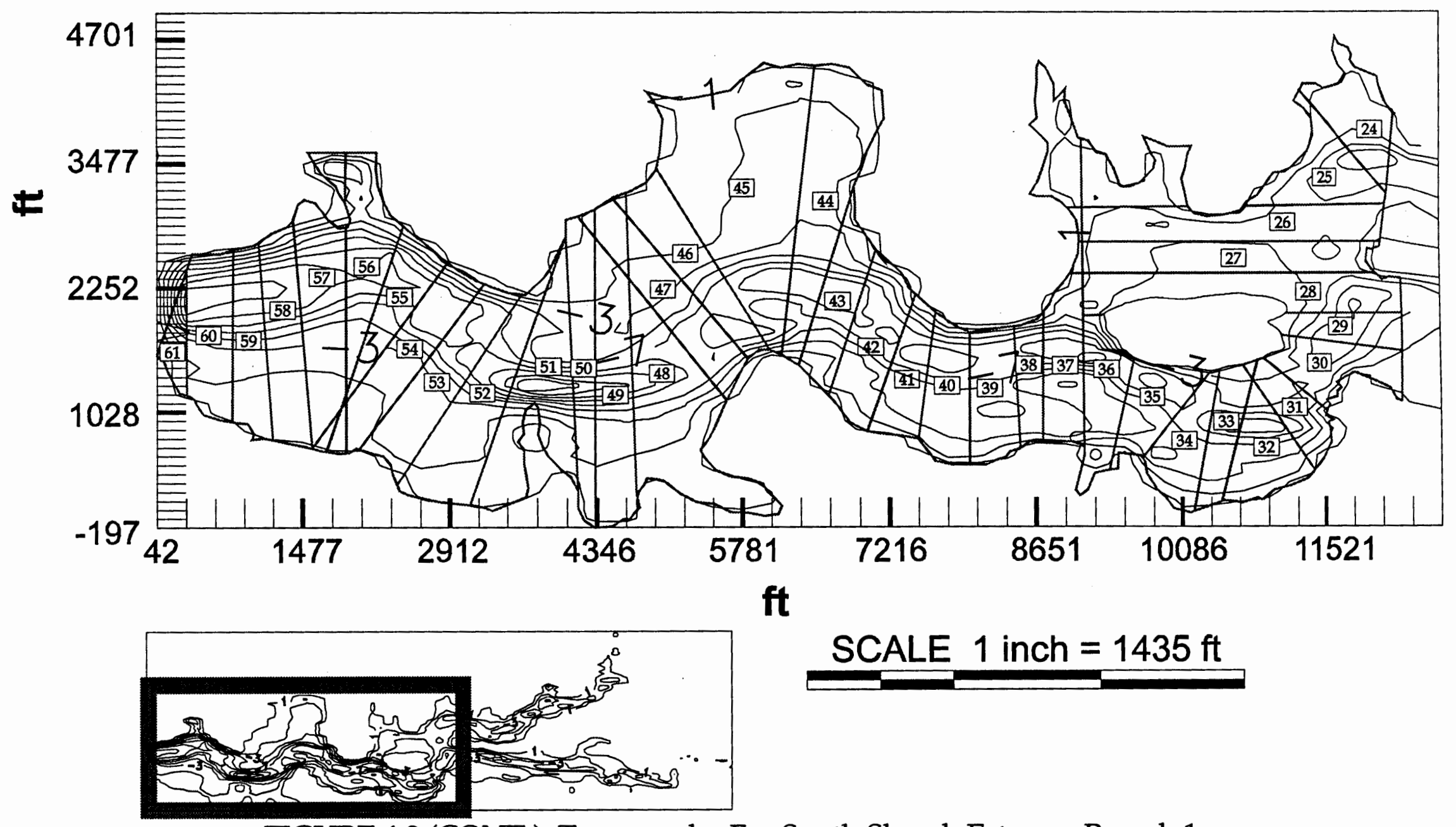

FIGURE 4.3 (CONT.) Topography For South Slough Estuary, Branch 1 

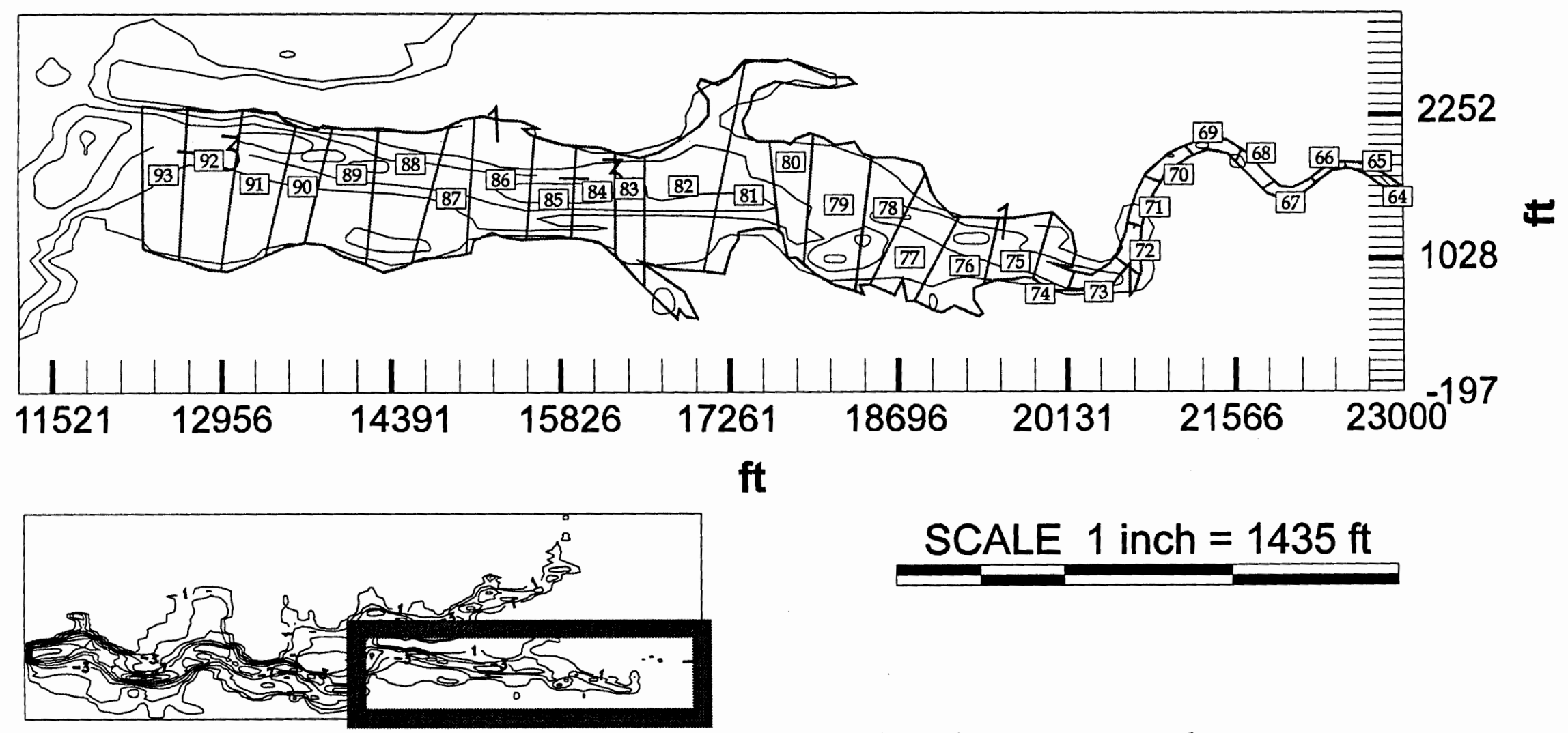

FIGURE 4.4 Topography For South Slough Estuary, Branch 2 


\section{Meteorological Data}

Meteorological data required for the model included air temperature, dew-point temperature, wind speed and direction and percent of cloudiness. Daily rainfall from the North Bend airport rain gage was used. The remaining meteorological data was collected at a station located near Hinch Road Bridge as documented in Wells and Baird (1990). Meteorological input data are shown in Figures 4.5 to 4.9 for Air Temperature, Dew Point, Wind Speed, Wind Direction and Cloud Cover respectively.

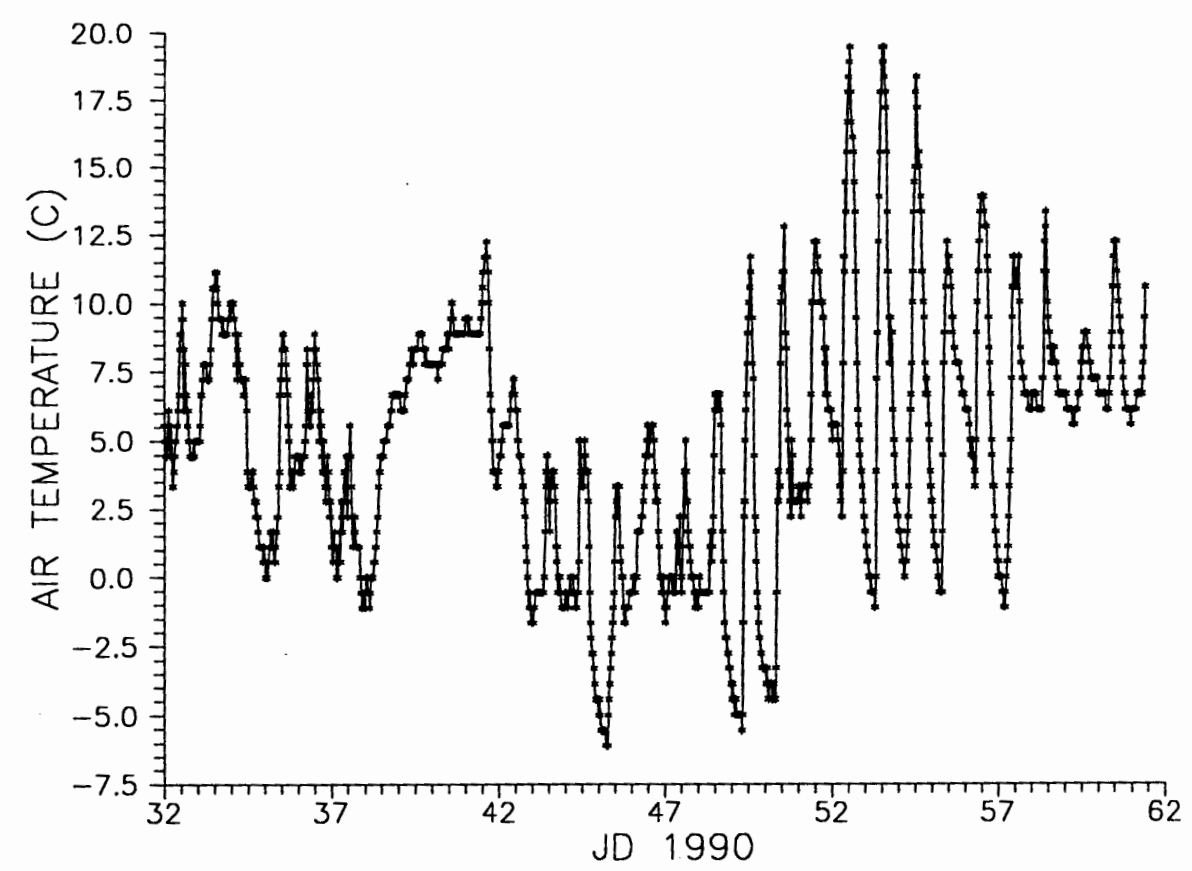

FIGURE 4.5 Air Temperature 


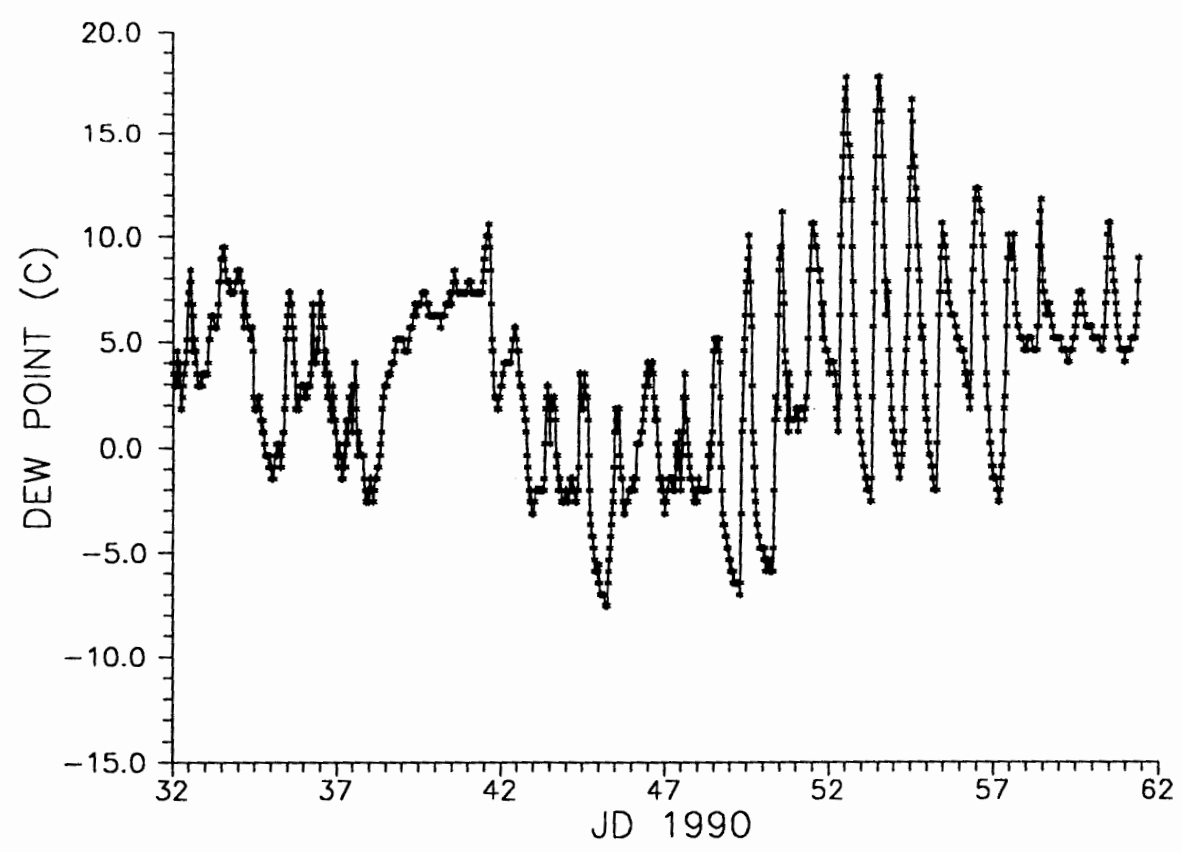

FIGURE 4.6 Dew Point

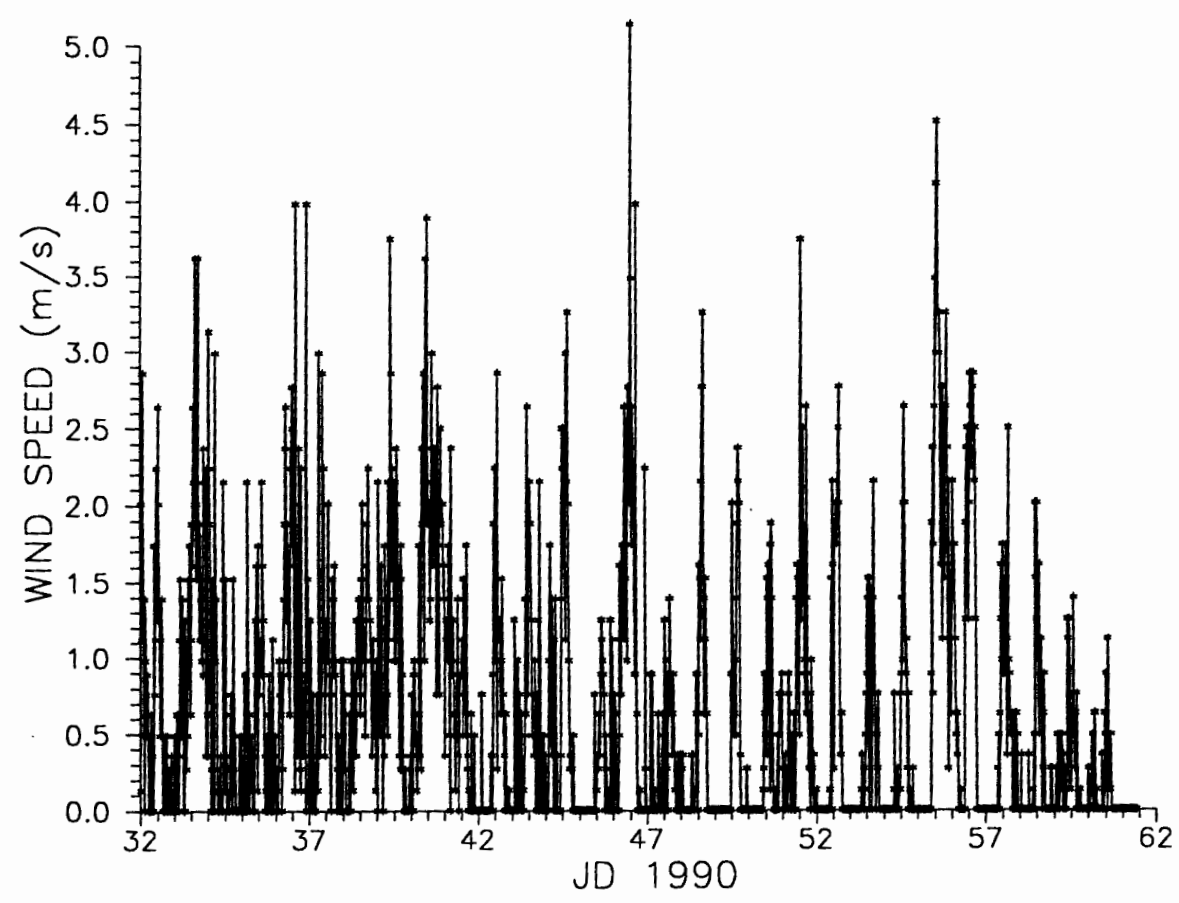

FIGURE 4.7 Wind Speed 


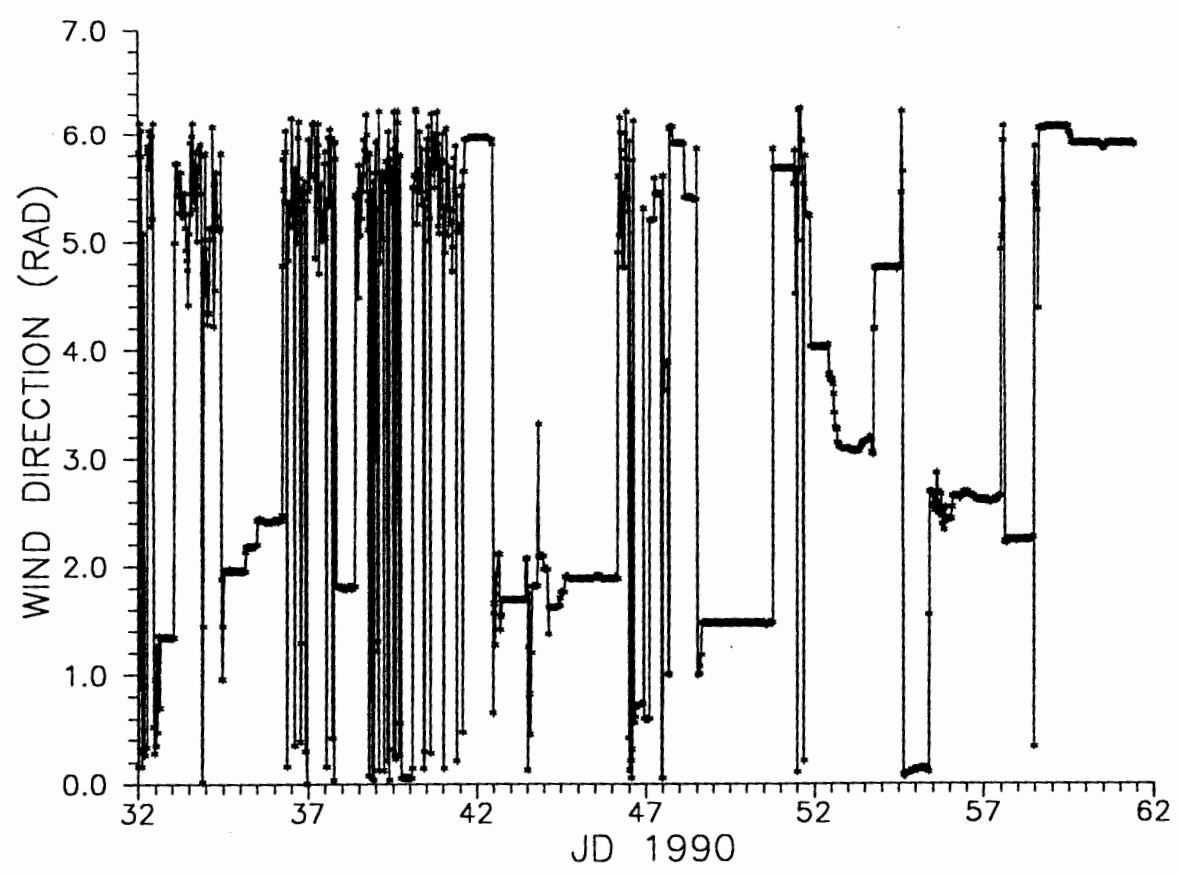

FIGURE 4.8 Wind Direction

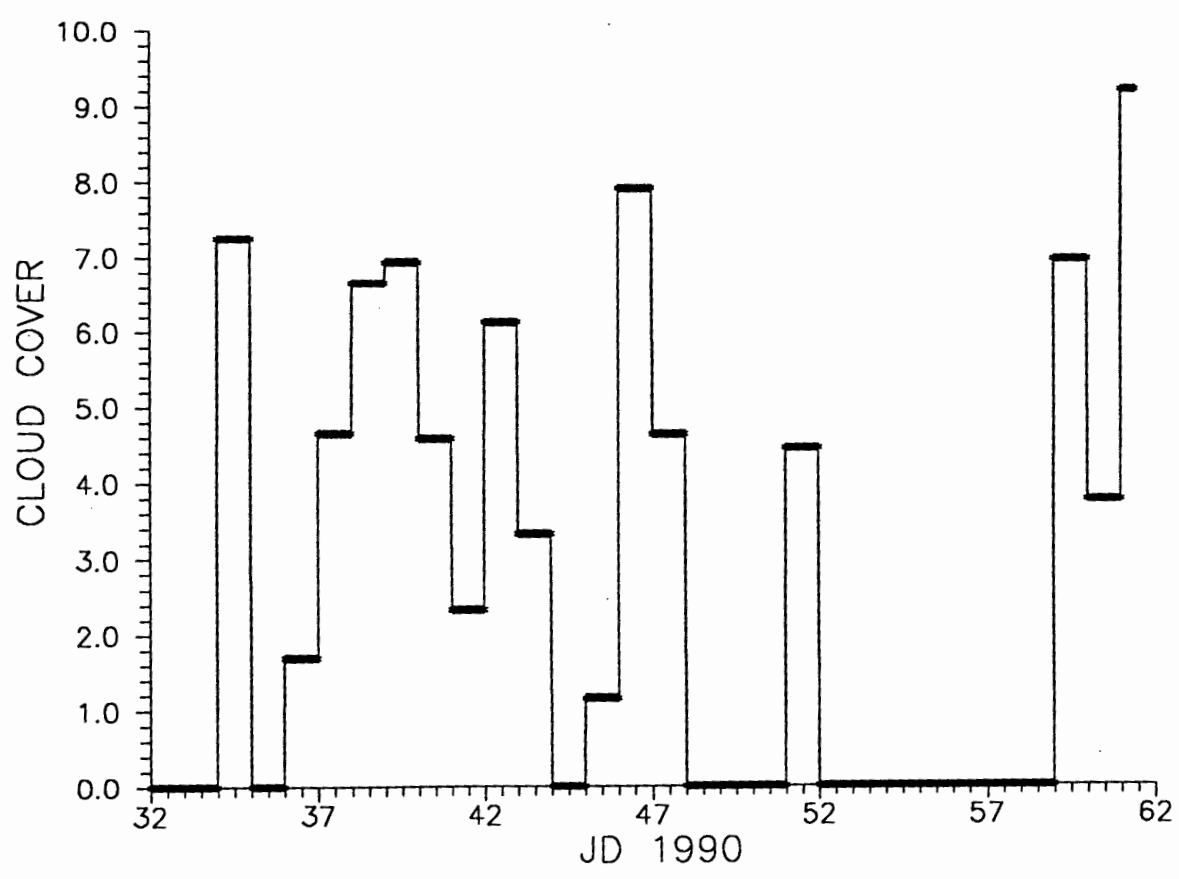

FIGURE 4.9 Cloud Cover 
The following equation was used to convert wind direction from degrees (WDDEG) to radians (WDRAD), since the field data were in degrees relative to due north:

$$
W D R A D=\frac{\pi}{180} W D D E G
$$

The relative humidity data collected were found to be incorrect for February and March of 1990. Some values collected dropped to zero, which is impossible especially in coastal regions. The relative humidity for January of 1990 ranged from $30-100 \%$, with and average relative humidity of $88.6 \%$. Therefore and approximate average relative humidity of $90 \%$ was assumed. Equation 24 was used to convert relative humidity to dew point temperature, knowing the air temperature:

$$
\begin{gathered}
\text { TDEW }=\text { TEMPC }-[(14.55+.114 T E M P C) x- \\
\left.((2.5+.007 T E M P C) x)^{3}+(15.9+.117 T E M P C) x^{14}\right]
\end{gathered}
$$

where

TEMPC $=$ the dry bulb air temperature in degrees Celsius $x=R H / 100$, relative humidity percent

Incident radiation was measured. The model however requires cloud cover as input. The Radiation was first converted to percent possible sunshine. This calculation was based on a procedure in "Effect of Geographical Variation on Recirculating Cooling Ponds" by Thackston (1974). A North Bend, Oregon latitude of 43.4167 degrees was used for this calculation.

Equation 25 converts percent possible sunshine, $p(k)$ to cloud cover:

$$
C C=10 \sqrt{1.2\left(1-\frac{p(k)}{100}\right)^{2 / 3}}
$$

\section{Inflows}

a. Flow Calculations, HEC-1 versus Rational Method 
There are six watersheds contributing to the South Slough:

Watershed

Winchester Creek

Joe Ney Slough

Talbot and John B Creek

Elliot Creek

Hayward and Farley Creek

Day Creek

\begin{tabular}{l} 
Areas (acres) \\
\hline 6098.4 \\
3232.2 \\
2429 \\
1976.6 \\
793.6 \\
568.7
\end{tabular}

Areas (acres)

6098.4

3232.2

2429

1976.6

568.7

The watershed areas were used to determine inflows.

The rainfall available for this study was daily rainfall measured at the North Bend Airport, which is close to the South Slough watershed area, and hourly rainfall at Bandon, 9 miles south along the coast. The raingage locations are shown in Figure 4.10. The North Bend Airport rain age is a non-recording type of gage that collects precipitation and temperature data. The Bandon rain gage is a recording station that collects precipitation, temperature and evaporation data. The Bandon raingage location is too far to be considered representative of the South Slough watershed area. Given only daily rainfall at the North Bend station the Rational Method was used to obtain runoff from the contributing watersheds. The Rational Method formula is $Q=1.01 C i A$, where $Q$ is the peak flow in $\mathrm{ft}^{3} / \mathrm{s}, A$ is the drainage basin area in acres, $i$ is the rainfall intensity in in $/ \mathrm{hr}$, and $C$ is a dimensionless runoff coefficient.

The Rational Method assumes that the maximum flow occurs when all the runoff from the contributing basin reaches the outlet. Rainfall durations longer than the time of concentration, as we are using for this study, would result in a lower peak flow. The Rational Method is a simplistic method that is generally considered to be an approximate model representing the flood peak that results from a given rainfall. This method assumes no temporary storage of water on the drainage basin surface and temporal and spatial variation of rainfall are neglected. The Rational Method is intended to be used to predict peaks flows and not used to determine flow over time. However, due to lack of available data $Q=1.01 \mathrm{CiA}$ was used as the average flow per day.

Estimating the value of " $\mathrm{C}$ " is a source of difficulty when using the Rational Method. The coefficient can be obtained from tables given the type of drainage area, but " $\mathrm{C}$ " may vary widely from storm to storm and increase as recurrence interval increases. The " $\mathrm{C}$ " value in the Rational formula would be critical to estimate flows accurately. To determine the value of " $\mathrm{C}$ ", a comparison of flows from HEC-1 flows to rational method flows was made. 


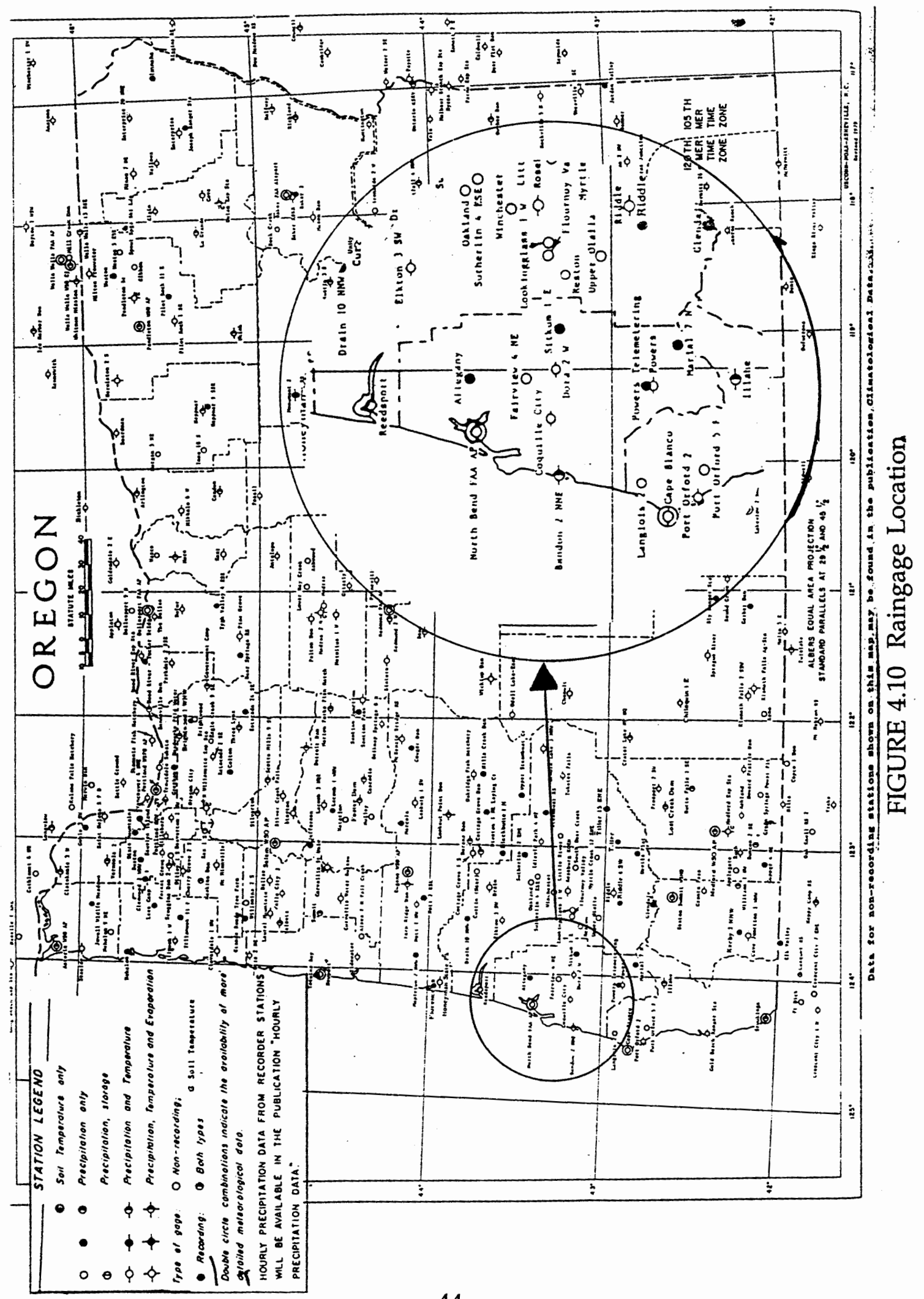


HEC- 1 is a computer model developed by the Hydrologic Engineering Center of the U.S. Army Corps of Engineers (September 1981). This program computes discharge hydrographs for historical or hypothetical design storms. Several methods for calculating the infiltration are provided in HEC-1. The Soil Conservation Service (SCS) Curve Number method was used in this analysis. This method is based on field data and experience relating drainage characteristics to soil group designations.

To use HEC- 1 accurately, more frequent rain data than were available at the North Bend Airport were needed. Daily North Bend rainfall data were converted to hourly data using the rainfall fluctuations at the Bandon station:

in $/ \mathrm{hr}$ North Bend $=\frac{\text { Total in/day North Bend }}{\text { Total in/day Bandon }} \mathrm{in} / \mathrm{hr}$ Bandon

When rainfall occurred in North Bend but did not occur in Bandon:

in $/ \mathrm{hr}$ North Bend $=\frac{\text { in/day North Bend }}{\mathrm{hr} / \text { day }}$

The time period analyzed was selected from four years: 1987, 1988, 1989, 1990. Figures 4.11 to 4.14 show inches/day versus Julian day at the North Bend rain gage for these four years respectively. One of the peak rainfall periods was in 1988, November 1 to November 6. The inputs for the SCS method include: SCS Curve number, CRVNBR; initial flow, STRTQ; flow at which exponential recession begins on the receding limb of the computed hydrograph, QRCSW; exponential decay rate (ratio of recession limb flow to the recession limb flow $1 \mathrm{hr}$ later), RTIOR; lag time, TLAG. The soil classification number for this area is 54; silt, moderate permeability, and runoff ranged from slow to rapid. 


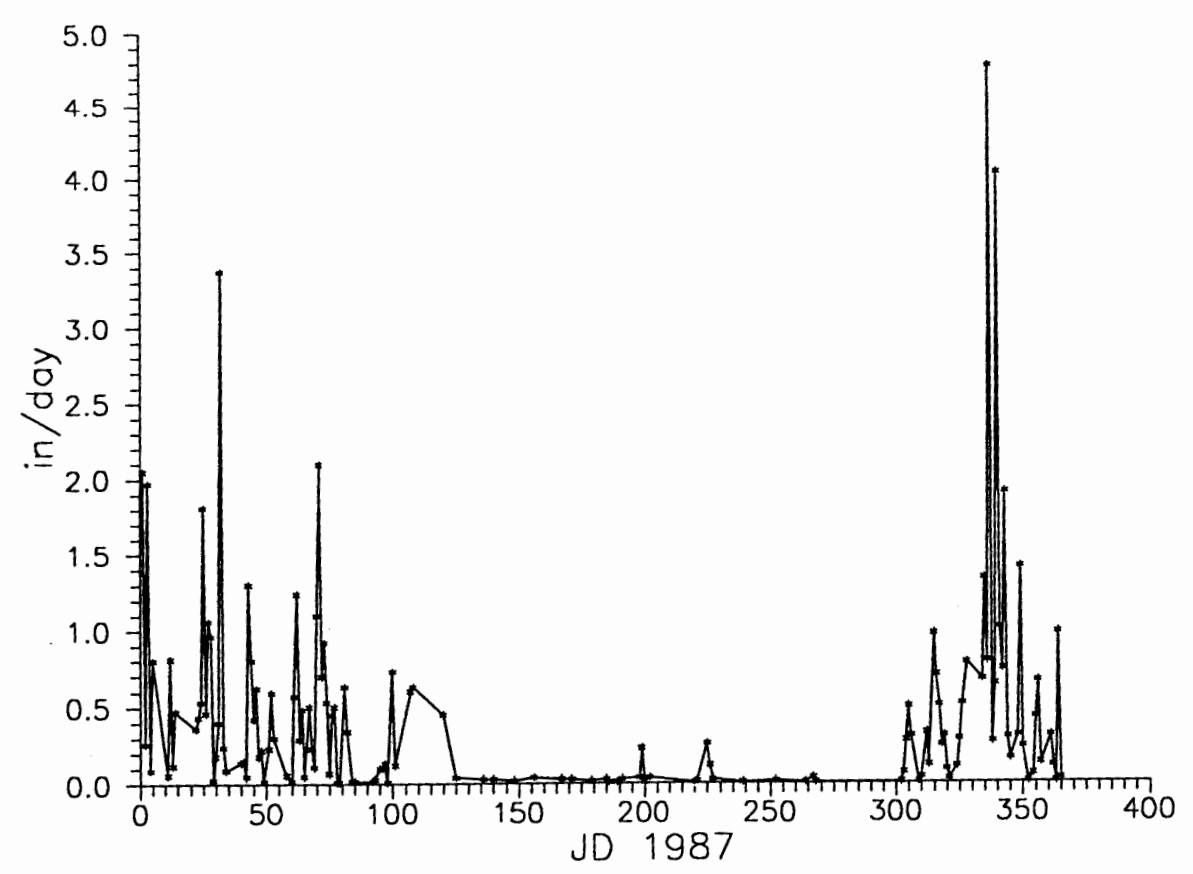

FIGURE 4.11 Rainfall North Bend Airport 1987

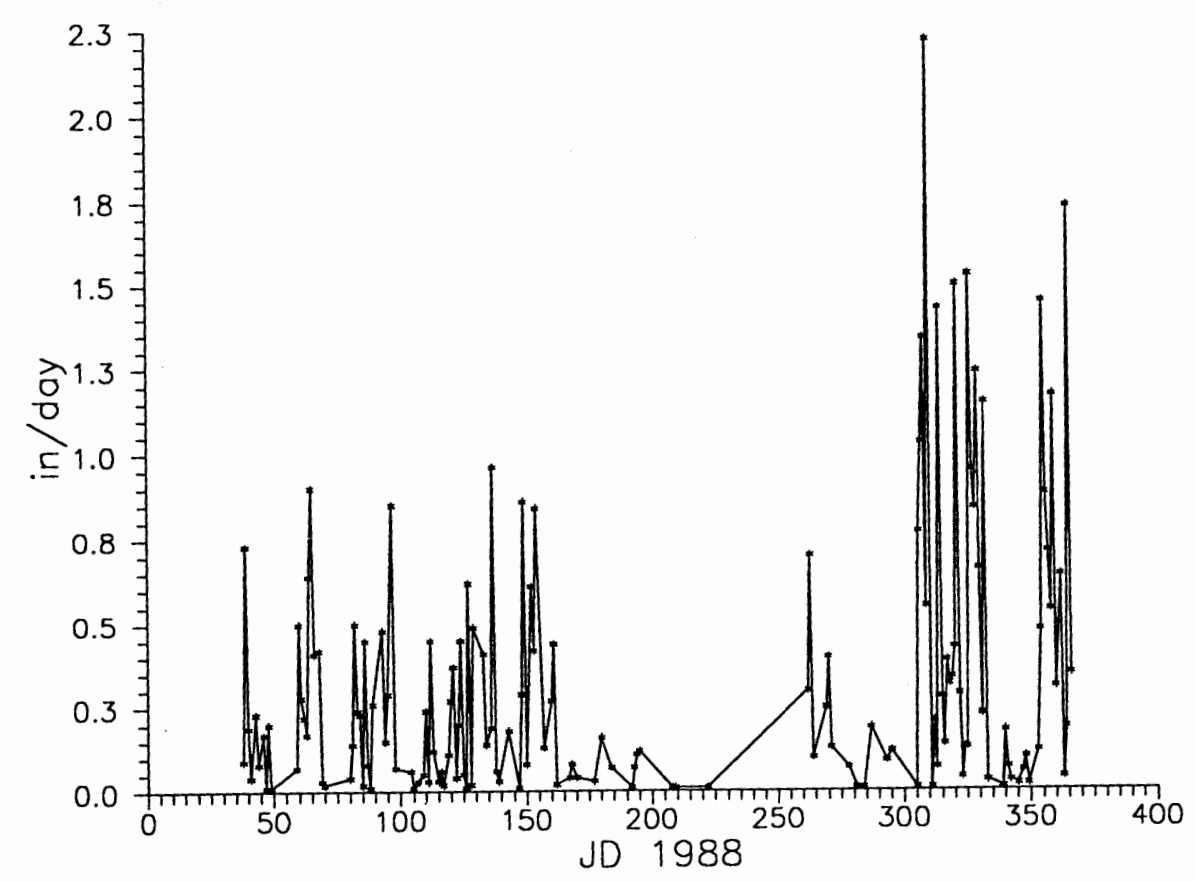

FIGURE 4.12 Rainfall North Bend Airport 1988 


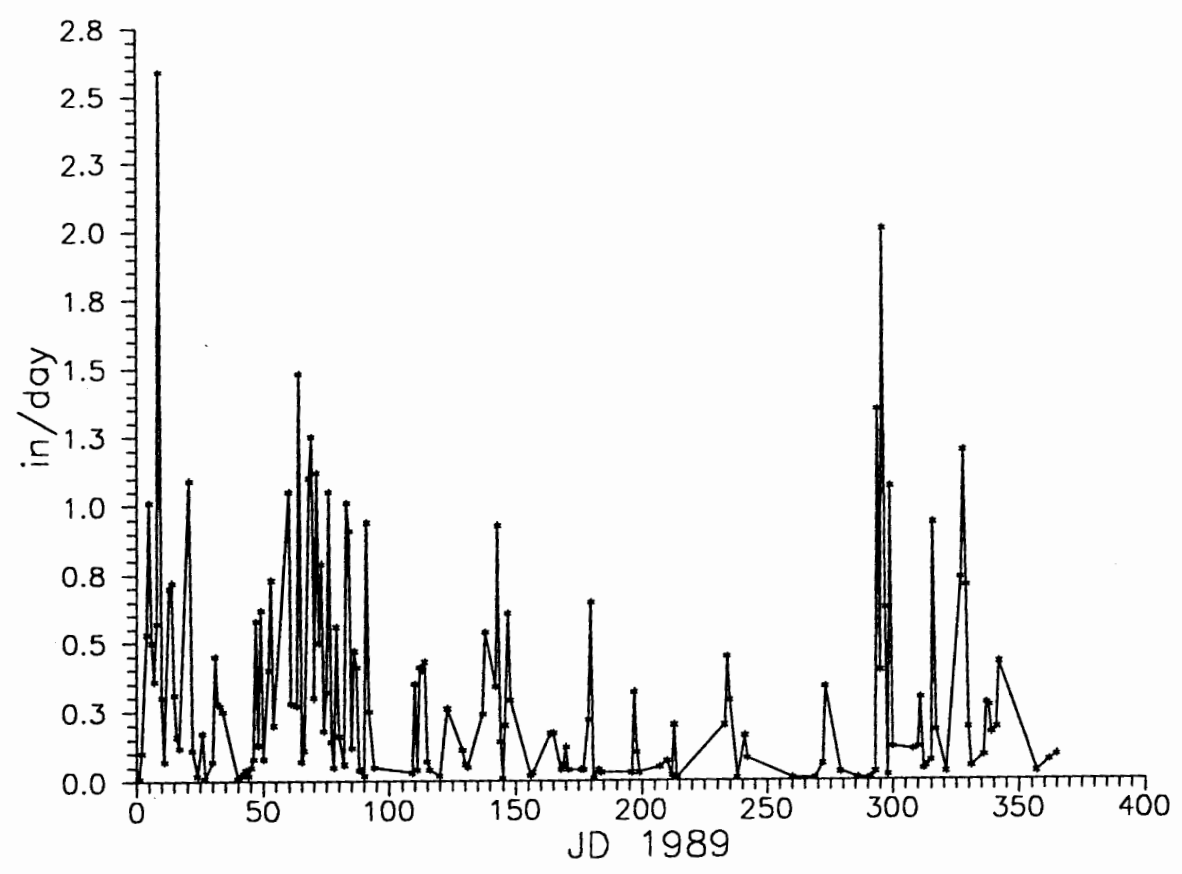

FIGURE 4.13 Rainfall North Bend Airport 1989

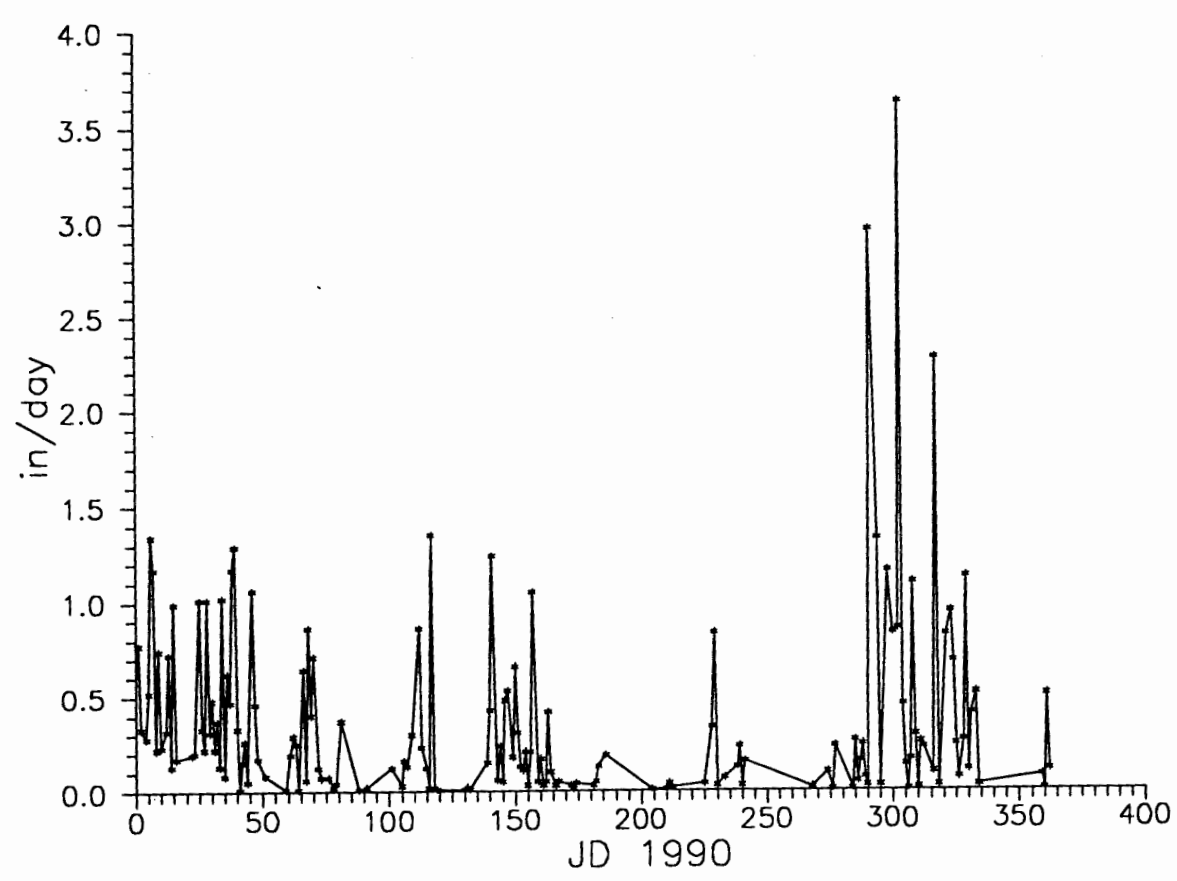

FIGURE 4.14 Rainfall North Bend Airport 1990 
To determine the sensitivity of these parameters an initial base condition was chosen and then, the different parameters were varied. Base condition was selected as follows:

STRTQ $=1.0 \mathrm{cfs}$

$\mathrm{QRCSN}=-.25 \mathrm{cfs}$

RTIOR $=1.2 \mathrm{cfs} / \mathrm{cfs}$

TLAG $=1.0 \mathrm{hr}$

CRVNBR $=61$

The SCS curve number is an index of the infiltration capacity of a specific soil and are based on antecedent moisture condition, hydrologic soil group, and land use. The base Condition SCS Curve number, CRVNBR, was obtained from a table in the Standard Handbook of Environmental Engineering (p7.26-7.28), using hydrologic soil group $B$ and pasture land in good condition.

For the first set of HEC-1 runs the exponent of decay, RTIOR was varied from 1.0 to $1.5 \mathrm{cfs} / \mathrm{cfs}$. The results are shown in Figure 4.15. As RTIOR increased the recession limb of the hydrograph dropped.

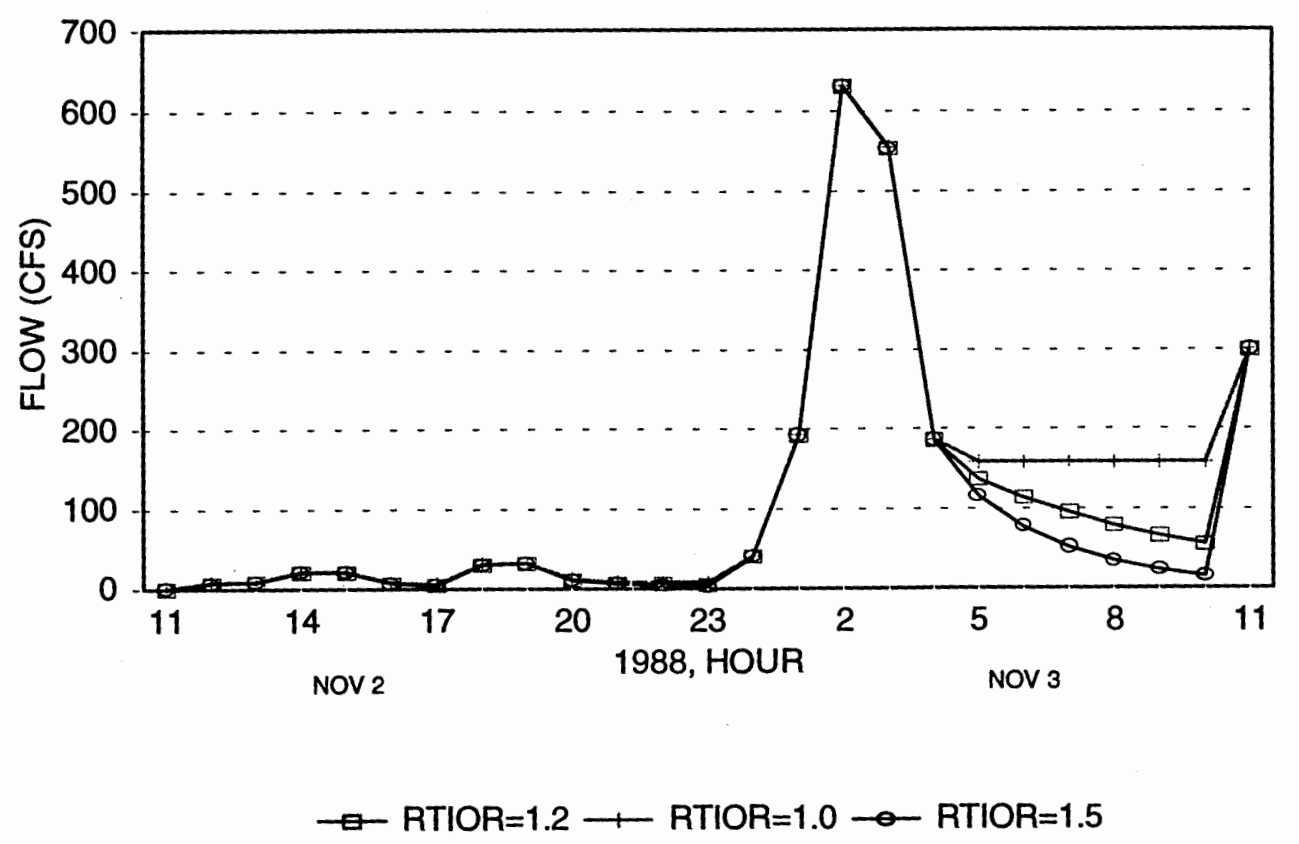

FIGURE 4.15 HEC-1 Method, Vary RTIOR 
For the second set of runs, QRCSN was varied from -.25 to $.25 \mathrm{cfs}$. The results are shown in Figure 4.16. The recession limb dropped when QRCSN was increased from -.25 to 0.0 but remained the same when increased from 0.0 to .25 .

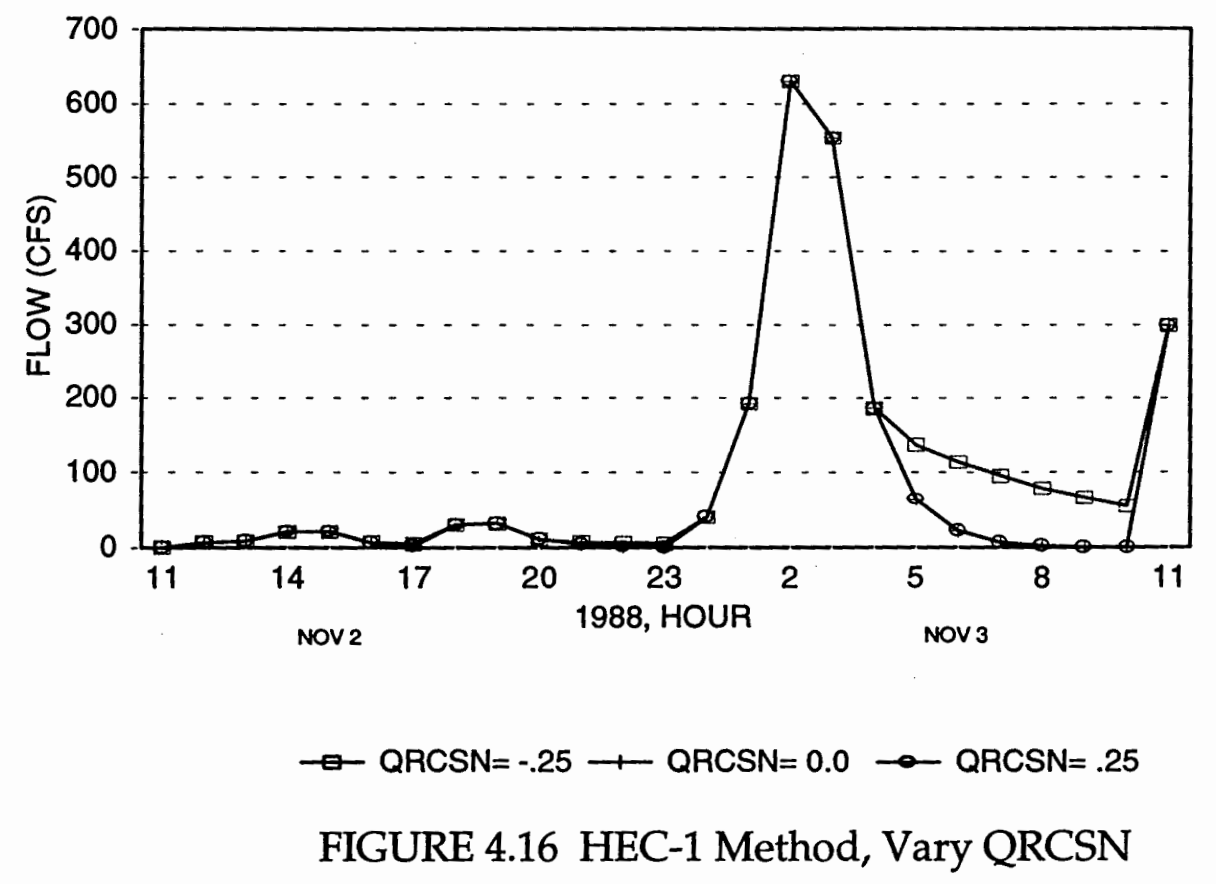


In third set of runs, TLAG was varied from 0.0 to 1.5 hours, and the results in predicted hydrograph are shown in Figure 4.17 and Table 4.5. TLAG effected the peak of the hydrograph. At a TLAG of 0.0 , the peak flow was approximately 980 cfs, at TLAG of 1.0 it was $630 \mathrm{cfs}$ and at TLAG of 1.5, it was $560 \mathrm{cfs}$.

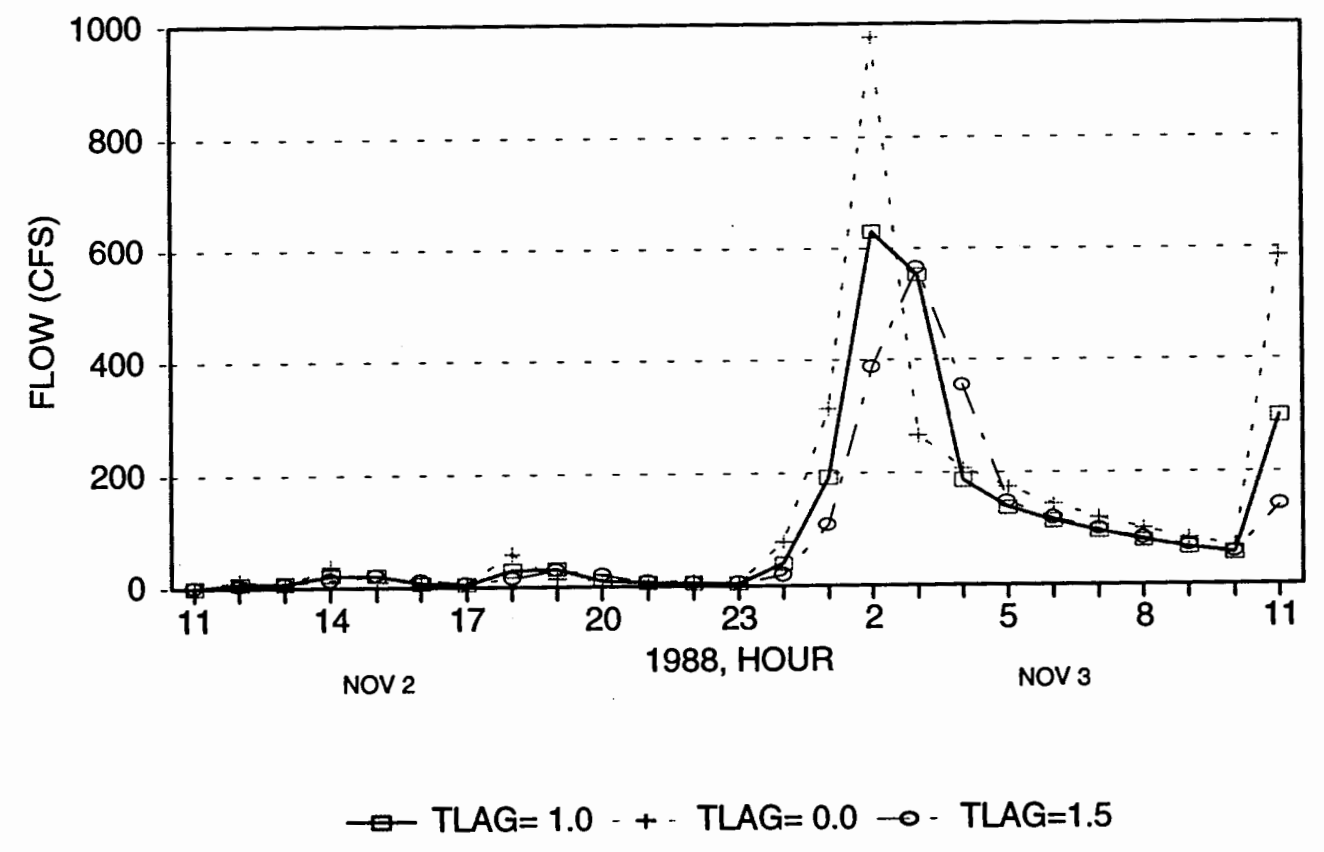

FIGURE 4.17 HEC-1 Method, Vary TLAG 
For the final set of HEC-1 runs, CRVNBR was varied. This also affected the peak flow of the hydrograph. Increasing the CRVNBR from 61 to 75 increased the peak flow from approximately 620 to $1380 \mathrm{cfs}$. These results are shown in Figure 4.18.

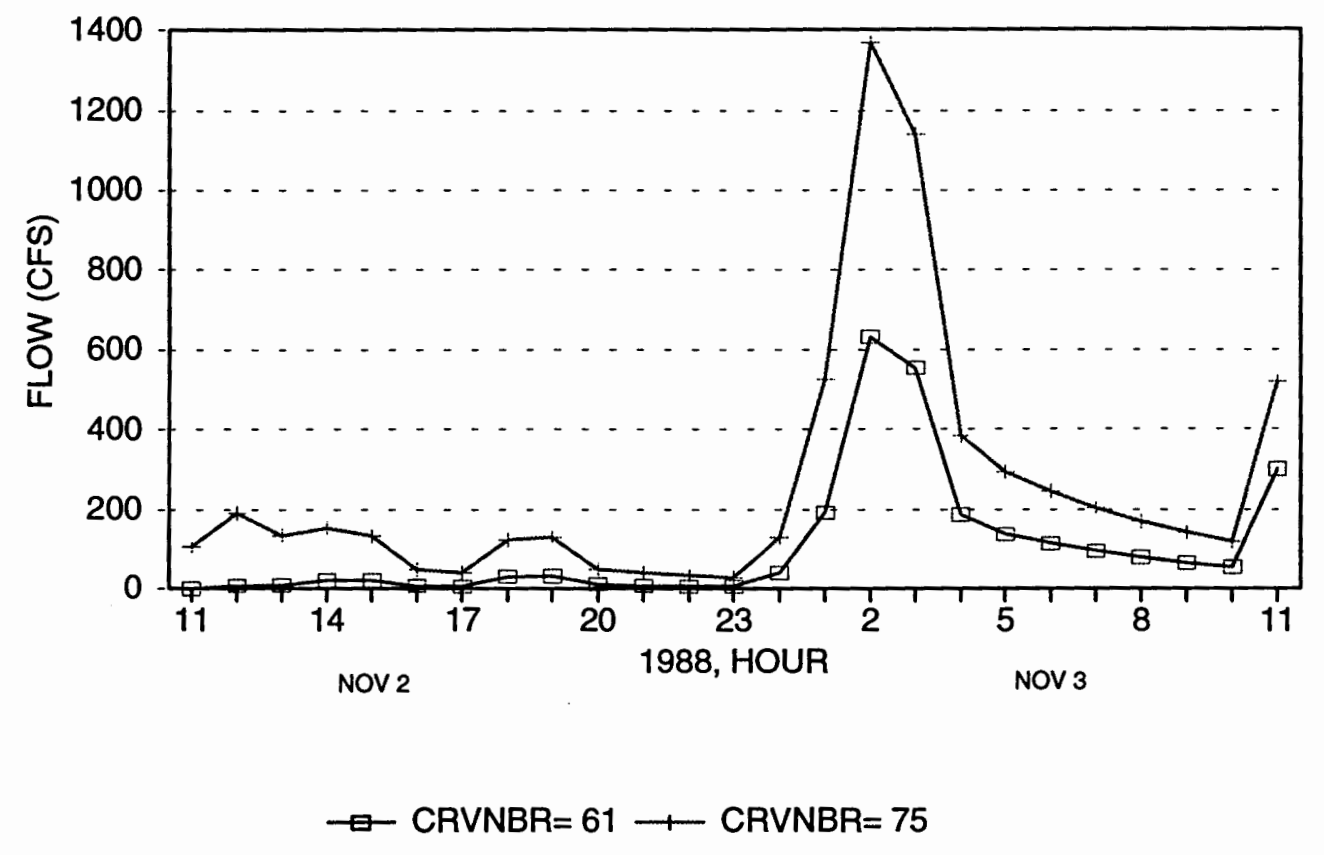

FIGURE 4.18 HEC-1 Method, Vary CRVNBR 
After examining the sensitivity of the HEC-1 model coefficients the Rational Formula was compared to the HEC-1 model in order to determine an appropriate value of " $\mathrm{C}$ ". Using the Rational Formula with the North Bend raingage data, values of $C$ were varied and their hydrographs examined. The results are shown in Figure 4.19. As $C$ increased so did the peak flow rate. Examining November 5 we see that for $C$ values of $.1, .2$, and .5 , the peak flow in cfs was approximately 57,114 , and 285 , respectively.

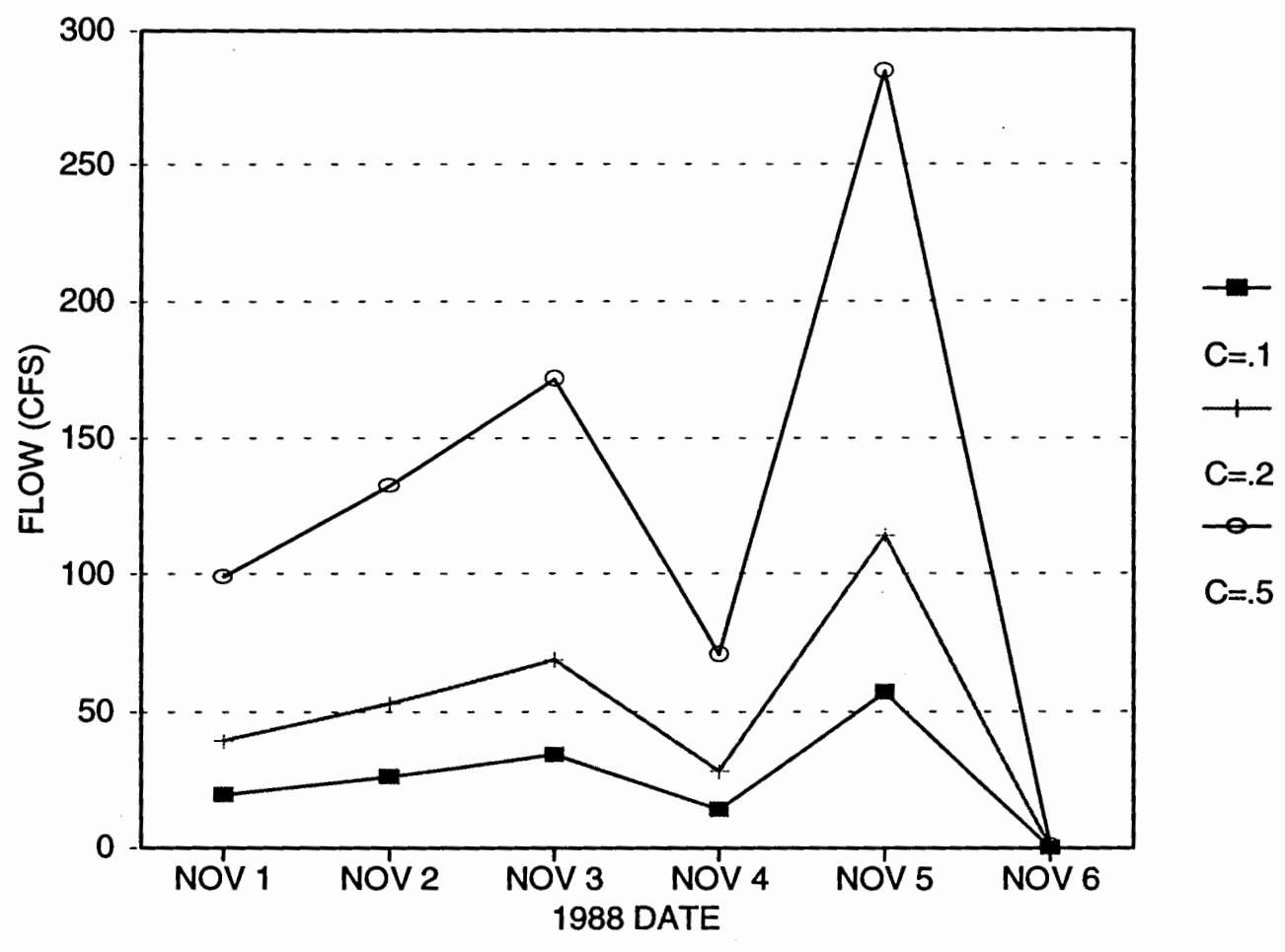

FIGURE 4.19 Rational Method (Q=1.01CIA) 
To determine which value of $C$ should be used for this project the varied values of $C$ were plotted against the hydrograph from HEC-1 using the base condition in Figure 4.20. For low flow periods the rational formula predicted a much higher peak flow and volume than HEC-1. During high flow periods, the Rational Formula peak flow was low compared to HEC-1. Looking for not a match in peak flows but in total volume, volume of flow for $\mathrm{C}=.5$ compared well with volume of flow for the HEC1 method. The Rational Formula $C=.5$ was selected to be used for calibration of this model.
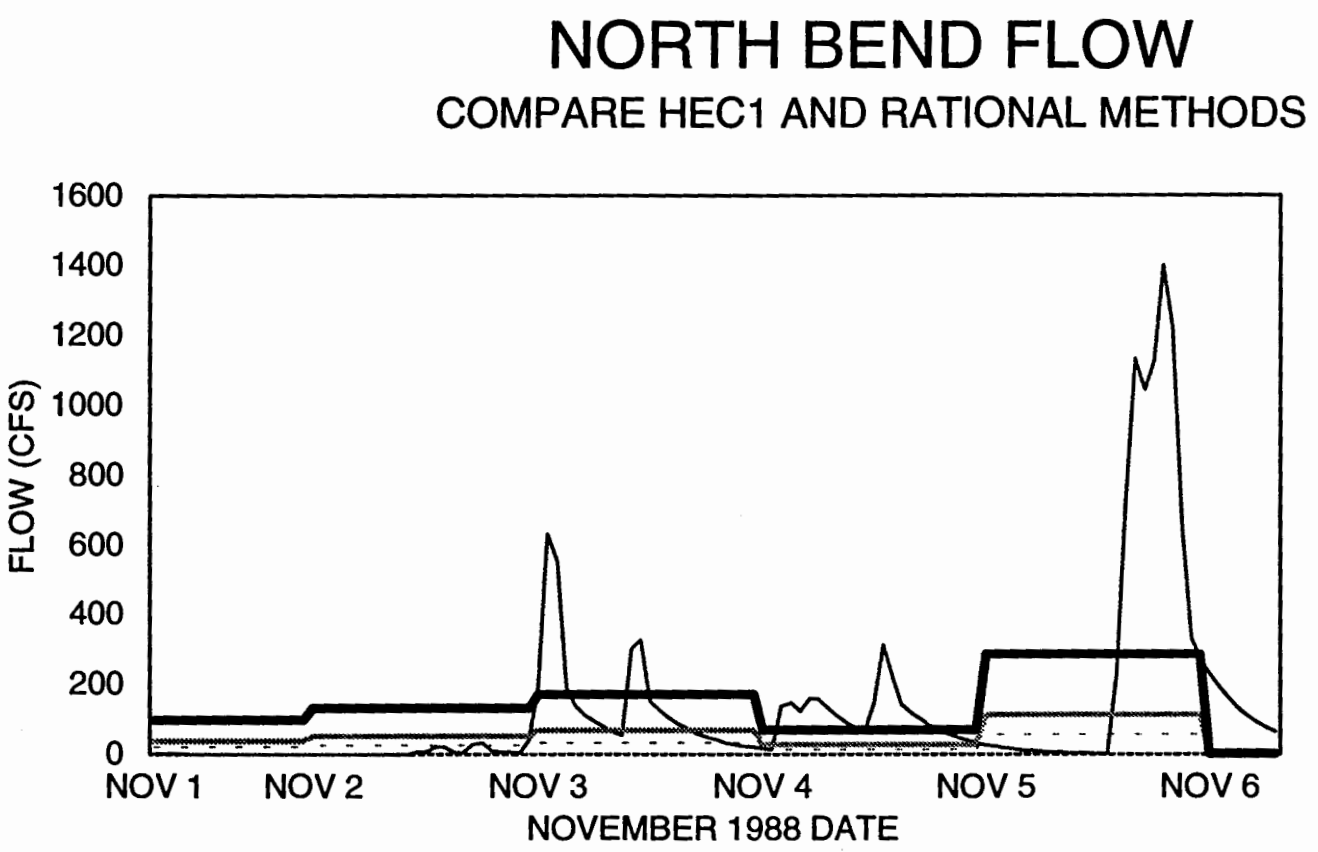

- HEC $1 \cdots \mathrm{C}=.1-\mathrm{C}=.2 \longrightarrow \mathrm{C}=.5$

FIGURE 4.20 Compare HEC-1 and Rational Methods

The calibration period for the water quality modeling was chosen as February 1, 1990 to March 15, 1990. Rainfall at the North Bend Airport during this calibration period is shown in Figure 4.21. Inflows from the six tributaries during the calibration period calculated using the Rational Formula with $C=.5$, are shown in Figures 4.22 to 4.27 . 


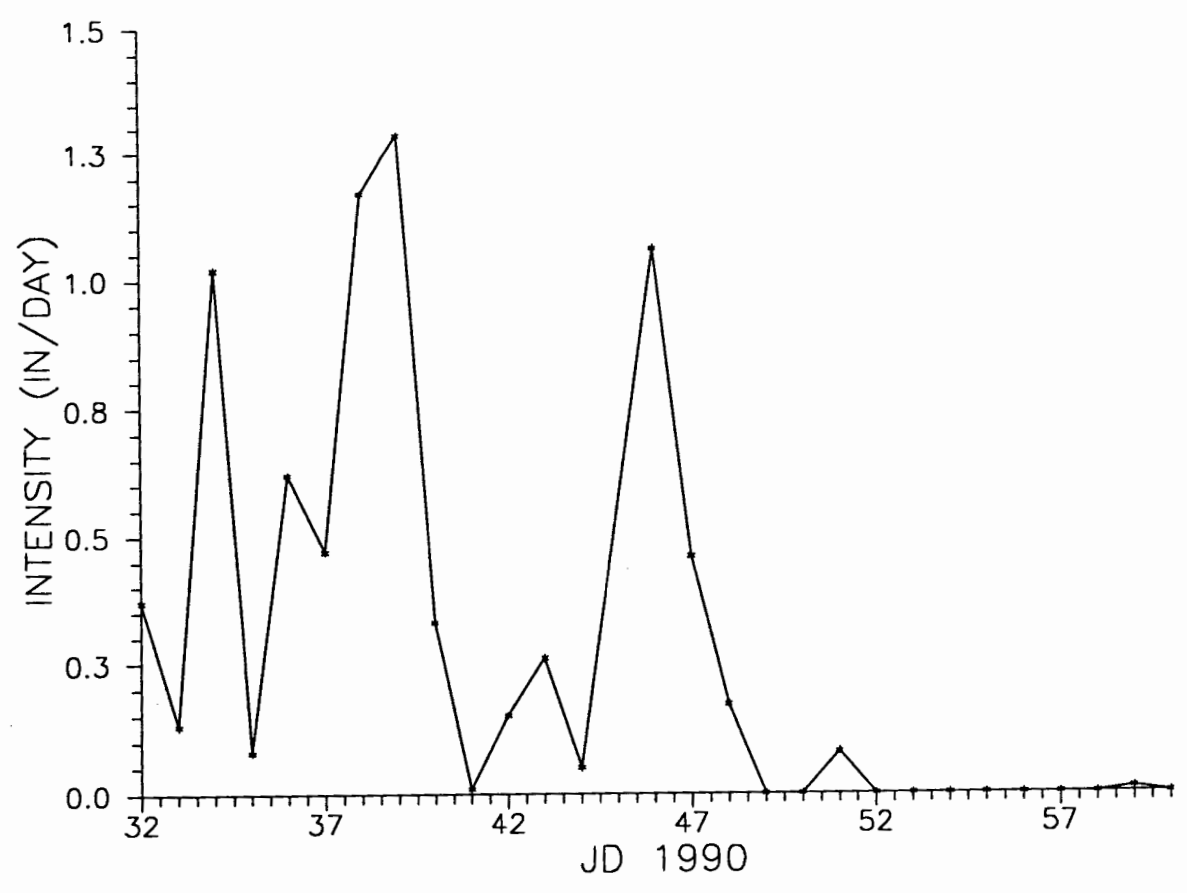

FIGURE 4.21 Rainfall at North Bend Airport

Calibration Period, Julian Day 32 TO 60

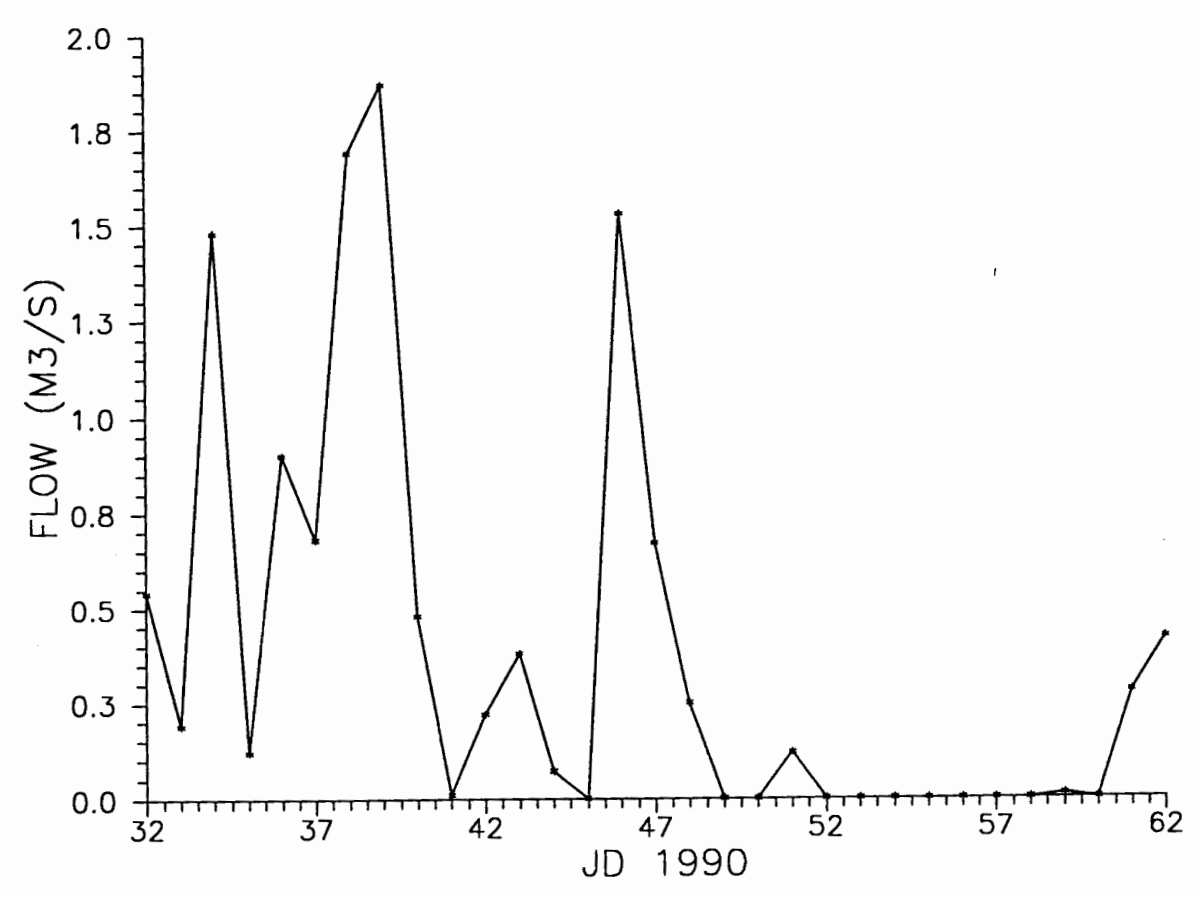

FIGURE 4.22 Flow for Talbot and John B. Creeks 


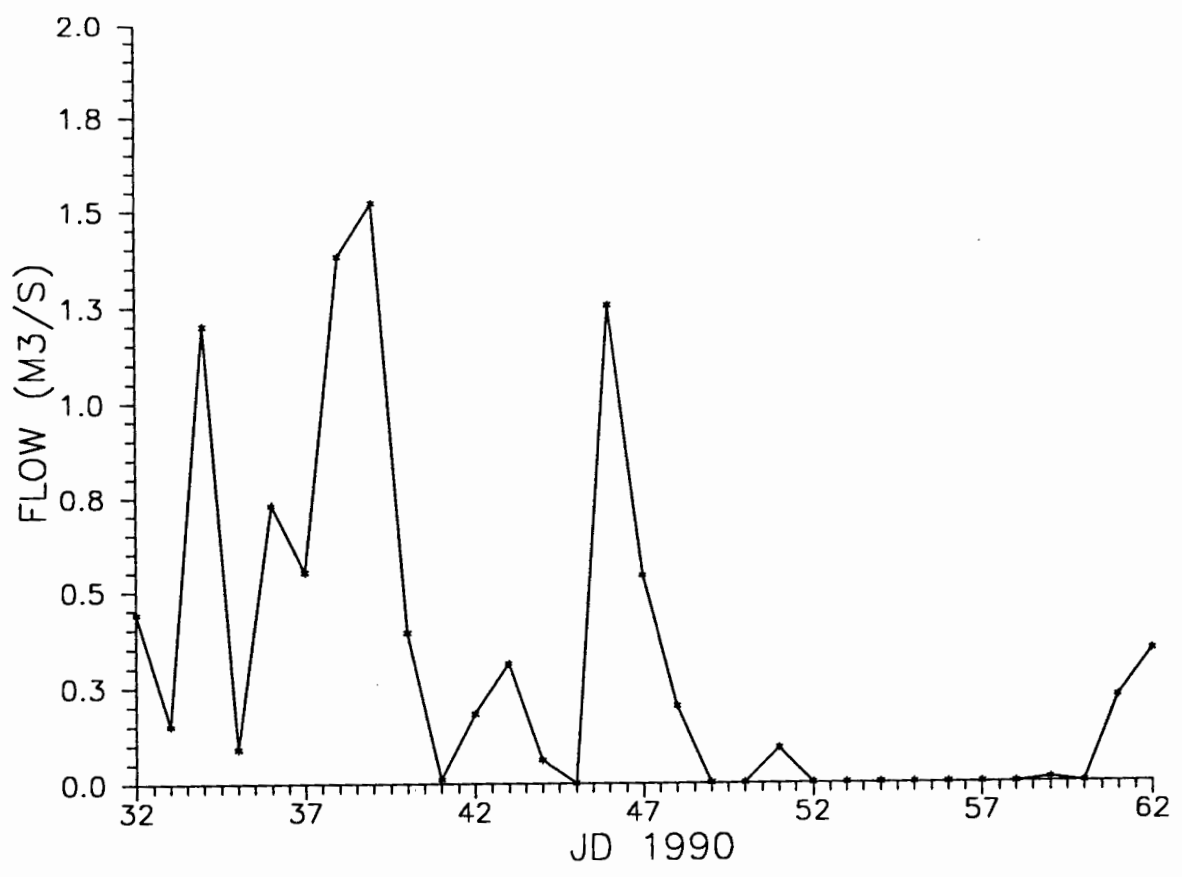

FIGURE 4.23 Flow for Elliot Creek

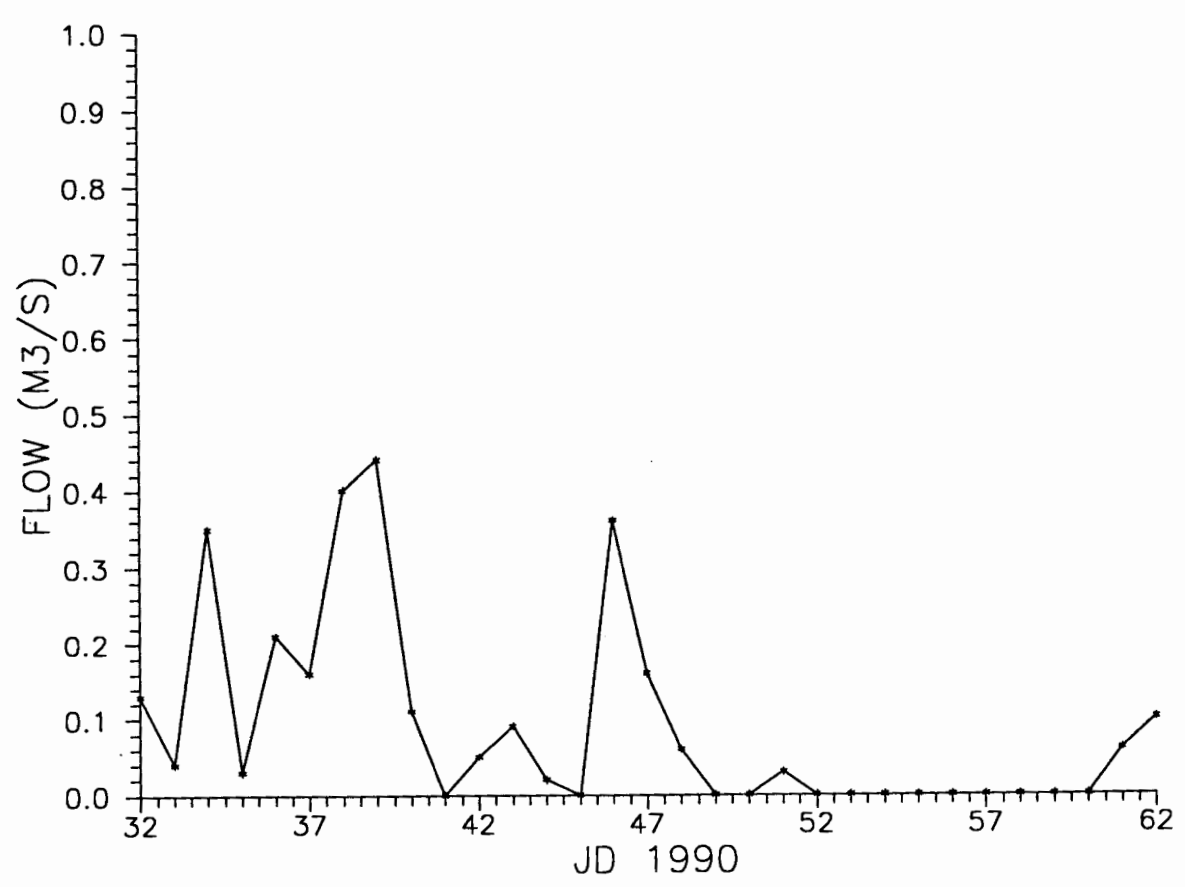

FIGURE 4.24 Flow for Day Creek 


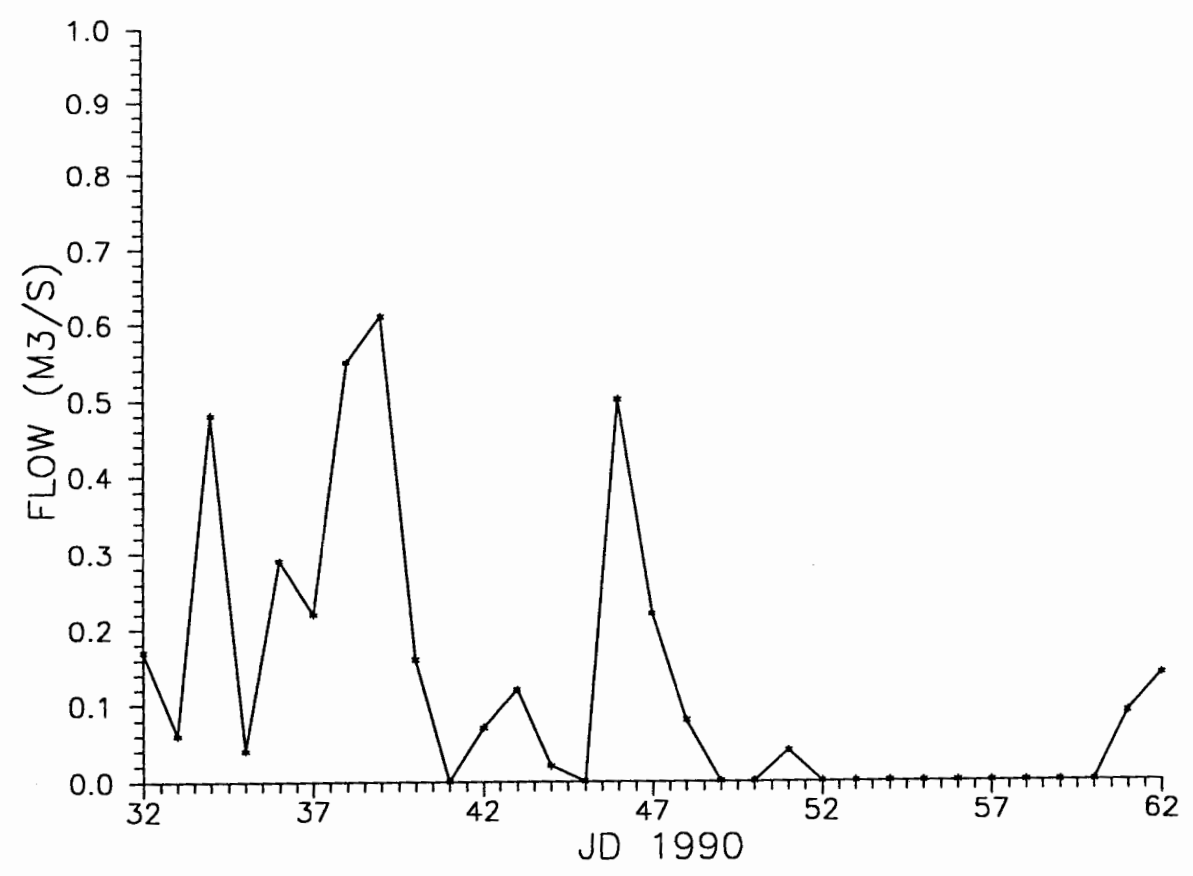

FIGURE 4.25 Flow for Hayward Creek

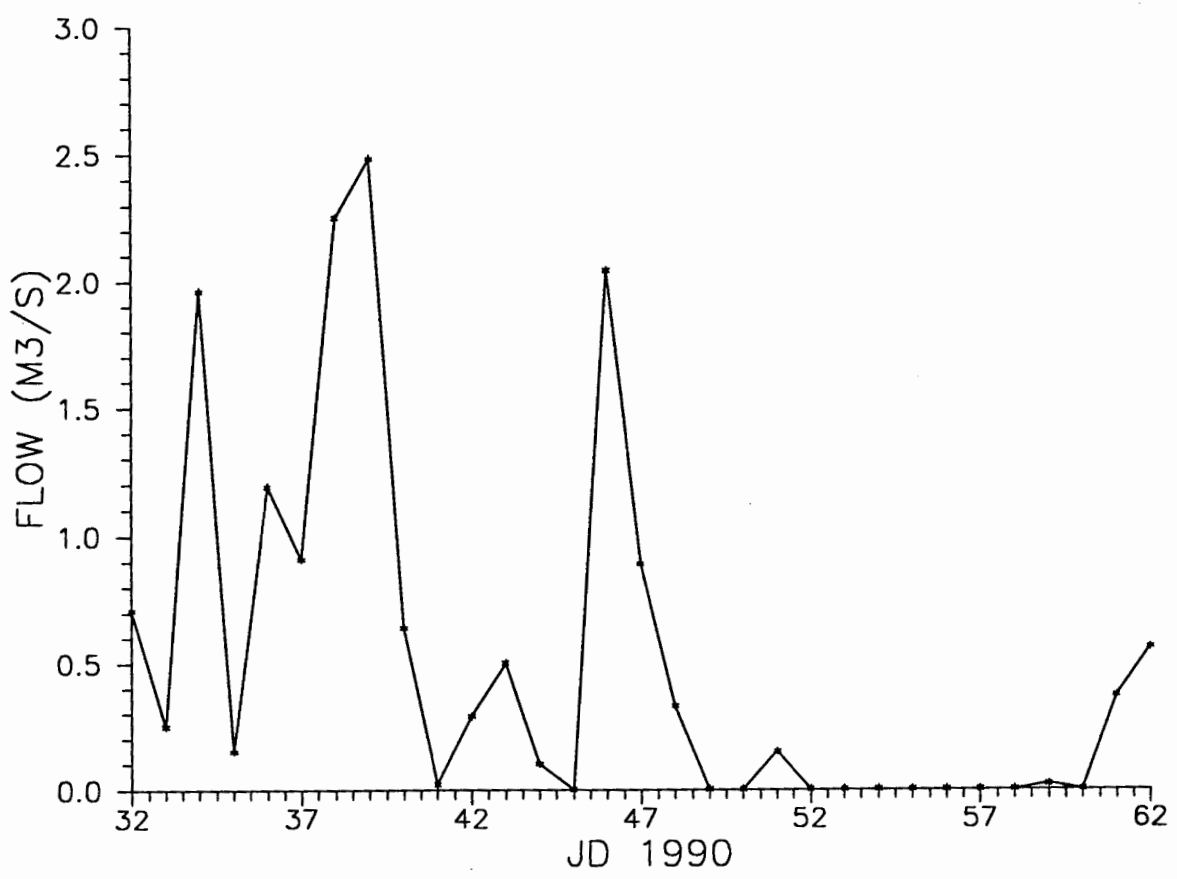

FIGURE 4.26 Flow for Joe Ney Slough 


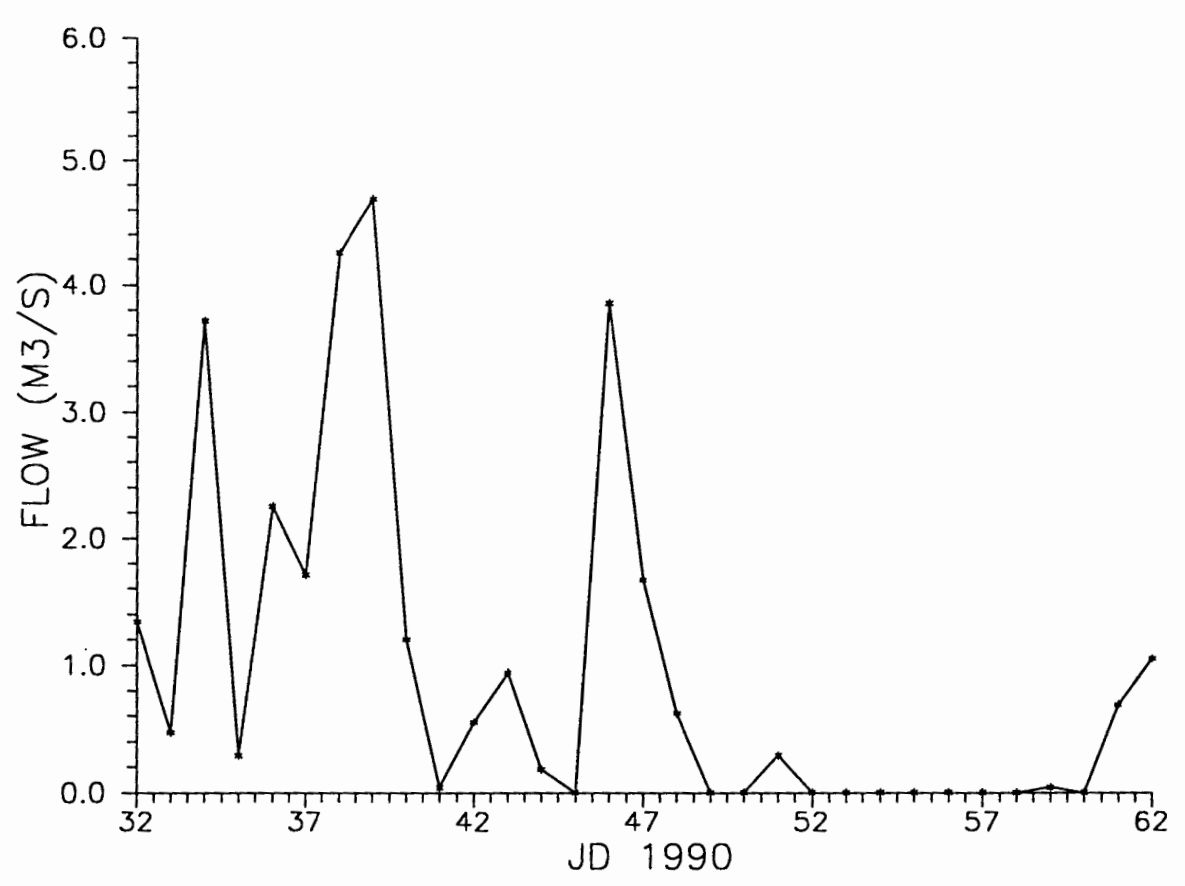

FIGURE 4.27 Flow for Winchester Creek

\section{b. Temperature and Concentrations}

No data were available during the calibration period for temperature, suspended solids, coliform bacteria and total dissolved solids for the tributary inflows. The following values were initially assumed for all six tributary inflows and constant during the calibration period; temperature $=5.5^{\circ} \mathrm{C}$, suspended solids $=5.0 \mathrm{mg} / \mathrm{l}$, coliform bacteria $=50.0 \mathrm{col} / 100 \mathrm{ml}$, total dissolved solids $=100 \mathrm{mg} / 1$. These initial values were determined to be representative for winter conditions based on information provided by Wells and Baird (1990). These initial values were adjusted during calibration of the model.

\section{Downstream Boundary Conditions}

\section{a. Head}

Tidal elevations referenced to NGVD, were recorded at Charleston Harbor at the Coast Guard Station dock. Location of this station is shown in Figure 1.2 as continuous tidal height record. Figure 4.28 shows the tidal height during the calibration period, February 1 through March 15, 1990. 


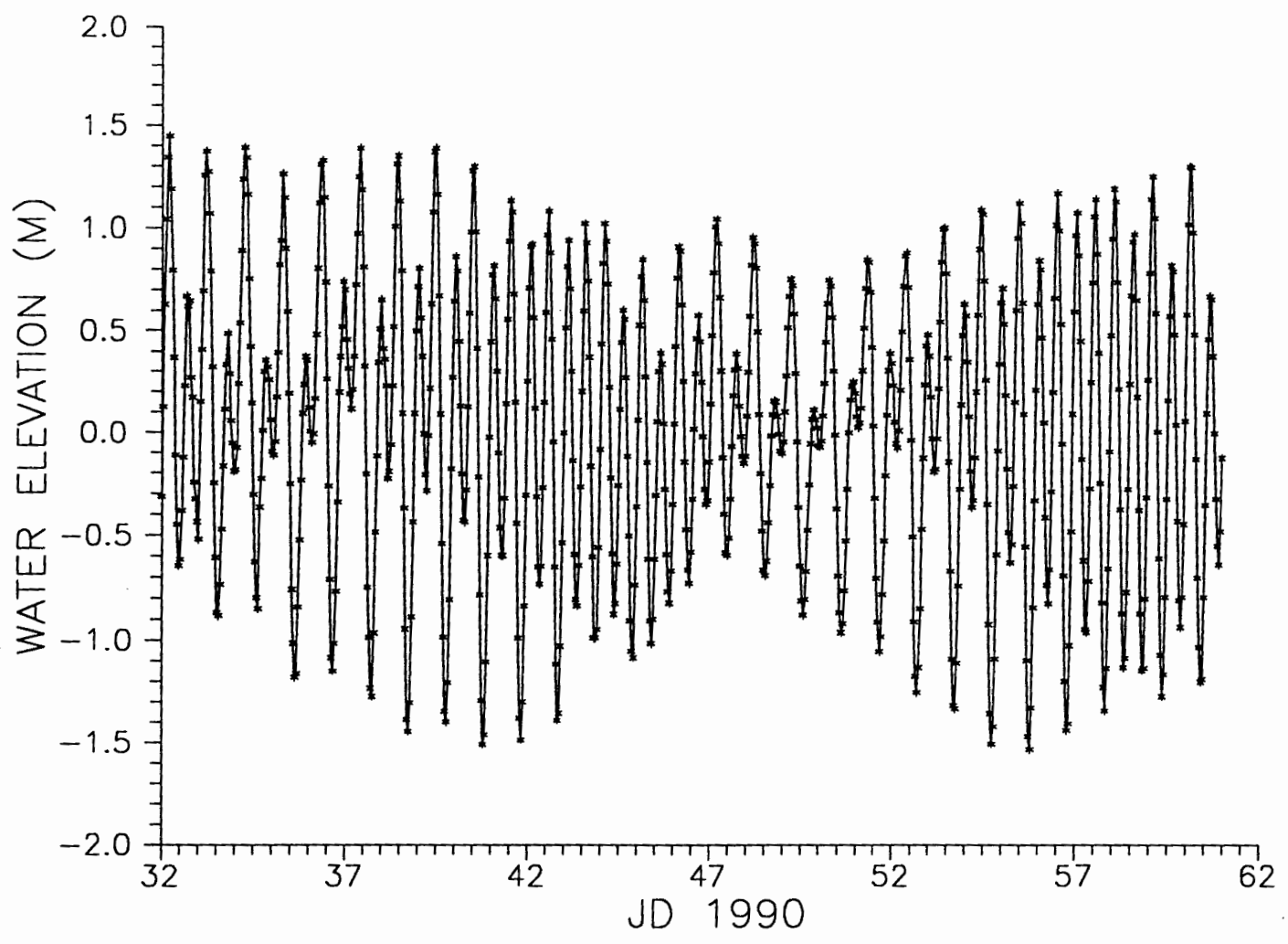

FIGURE 4.28 Charleston Harbor Water Elevations

b. Temperature and Concentrations

Temperature and concentration data were not recorded at Charleston Harbor. Field data from the $S 4$ current meter, located north of Valino Island were used to estimate downstream boundary conditions for temperature and conductivity. It was assumed that when the tide was at high water slack, that the temperature and conductivity values at the Valino Island S4 current meter location would be similar to those found at Charleston Harbor during an incoming tide. High salinity values at Valino Island signaled high tide, ocean water. These values were sorted from the S4 current meter data file and reformatted for the downstream boundary temperature file and concentration file. This procedure is illustrated in Table 4.3. 


\begin{tabular}{|c|c|c|c|}
\hline $\begin{array}{l}\text { Julian } \\
\text { Day }\end{array}$ & $\begin{array}{c}\text { Cond } \\
(\mathrm{ms} / \mathrm{cm})\end{array}$ & $\begin{array}{c}\text { Temp } \\
\text { (c) }\end{array}$ & $\begin{array}{c}\text { Salinity } \\
\text { (psu) }\end{array}$ \\
\hline 33.001 & 19 & 8 & 17 \\
\hline 33.022 & 20 & 8 & 18 \\
\hline 33.042 & 21.3 & 8.1 & 19 \\
\hline 33.063 & 22.7 & 8.3 & 20. \\
\hline 33.084 & 22.1 & 8.3 & 20 \\
\hline 33.105 & 22.8 & 8.4 & 20. \\
\hline 33.126 & 26.1 & 8.8 & 23 \\
\hline 33.147 & 28.9 & 9.2 & 26. \\
\hline 33.167 & 30.2 & 9.3 & 27. \\
\hline 33.188 & 30 & 9.3 & 27 \\
\hline 33.209 & 29.7 & 9.2 & \\
\hline 33.23 & 29.5 & 9.2 & \\
\hline 33.251 & 26.9 & 8.7| & 24. \\
\hline 33.272 & 23.9 & 8.4 & 21. \\
\hline 33.292 & 22.9 & 8.4 & 20. \\
\hline 33.313 & 21.3 & 8.2 & 19. \\
\hline 33.334 & 20.4 & 8.1 & 18. \\
\hline 33.355 & 20 & 8.1 & 18 \\
\hline 33.376 & 19.6 & 8.1 & 17. \\
\hline 33.397 & 18.6 & 8.1 & 16. \\
\hline 33.417 & 17.4 & 8.1 & 15. \\
\hline 33.438 & 16.2 & 8.1 & 14. \\
\hline 33.459 & 15.3 & 8.1 & 13 \\
\hline 33.48 & 14.9 & 8.2 & 13 \\
\hline 33.501 & 15.2 & 8.4 & 13. \\
\hline 33.522 & 15.3 & 8.5 & 13. \\
\hline 33.542 & 15.8 & 8.6 & 13. \\
\hline 33.563 & 17.1 & 8.6 & 15. \\
\hline 33.584 & 17.9 & 8.7 & 15 \\
\hline 33.605 & 18.4 & 8.7 & 16. \\
\hline 33.626 & 19.3 & 8.8 & 17. \\
\hline 33.647 & 20.5 & 8.8 & 18. \\
\hline 33.667 & 21.7 & 8.8 & 19. \\
\hline 33.688 & 21.2 & 8.8 & \\
\hline 33.709 & 21 & 8.7 & 18. \\
\hline 33.73 & 21.2 & 8.7) & \\
\hline 33.751 & 21.7 & 8.7) & 19. \\
\hline 33.772 & 20.7 & 8.8 & \\
\hline 33.792 & 20.5 & 8.8 & \\
\hline
\end{tabular}

Input Data File South Slough

Downstream Boundary Condition

Temperature

\begin{tabular}{|c|c|c|c|c|c|c|c|c|c|}
\hline JDAY & $K=2$ & $K=3$ & $K=4$ & $K=5$ & ETC & & & & \\
\hline \multirow{2}{*}{33.17} & 9.3 & 9.3 & 9.3 & 9.3 & 9.3 & 9.3 & 9.3 & 9.3 & 9.3 \\
\hline & 9.3 & 9.3 & 9.3 & 9.3 & & & & & \\
\hline \multirow[t]{2}{*}{33.75} & 8.7 & 8.7 & 8.7 & 8.7 & 8.7 & 8.7 & 8.7 & 8.7 & 8.7 \\
\hline & 8.7 & 8.7 & 8.7 & 8.7 & & & & & \\
\hline \multirow[t]{2}{*}{34.23} & 9.3 & 9.3 & 9.3 & 9.3 & 9.3 & 9.3 & 9.3 & 9.3 & 9.3 \\
\hline & 9.3 & 9.3 & 9.3 & 9.3 & & & & & \\
\hline \multirow[t]{2}{*}{34.71} & 8.6 & 8.6 & 8.6 & 8.6 & 8.6 & 8.6 & 8.6 & 8.6 & 8.6 \\
\hline & 8.6 & 8.6 & 8.6 & 8.6 & & & & & \\
\hline
\end{tabular}

Underlined Indicates High Salinity Time

Periods

This Occurs At High

Tide

Table 4.3 Boundary Condition For Temperature 


\section{Calibration Process}

The calibration period used was Julian day 32 to 60, February 1 to March 1, of 1990. Data model predictions were made at two locations: near Hinch Road Bridge in the Winchester Creek arm (model cell 63) and north of Valino Island, where the S4 current meter was located (model cell 37). The monitoring locations are shown in Figure 1.2. Water surface elevations, current velocity, current direction, temperature and conductivity were collected by the S4 Current Meter. Water elevations were collected at Hinch Road Bridge station. Meteorological data (air temperature, wind speed, wind direction, solar radiation, and relative humidity) were collected near the Hinch Road bridge.

The S4 current meter measured the height of water above the sensor and floated upward during low water. Sometime between 12-15-89 to 3-2-90, (calibration period 2-1-90 to 3-1-90) Wells and Baird (1990) reported that the S4 current meter had become detached from the mooring. The MSL location of the S4 was not surveyed explicitly and the NGVD reading was approximate.

\section{Hydraulics}

The initial calibration effort focused on water surface elevations. The first modeling runs terminated before the end of the simulation period due to numerical instabilities. There were large changes in neighboring cell widths (on the order of 20 times). In the bathymetry file, smooth transitions of the channel width were made to surrounding cells. This minor change in bathymetry would have no effect on modeling results. Water elevations were also dropping below the datum for the entire Winchester Creek arm. Although Winchester Creek may actual dry out, CEQUAL W2 will not simulate this condition. A top vertical layer was added to the Bathymetry file, increasing the number of layers from 13 to 14 to allow the water levels to rise above $1.83 \mathrm{~m}$, the top or cell 13. The widths for the new was assumed to be $10 \%$ larger than the prior layer.

Results of the modeled water surface elevations were compared to the measured elevations at the Hinch Road Bridge station. Modeled water surface elevations were found to be considerably higher than the measured elevations. Various Chezy coefficients were used and results of water surface elevations at Chezy coefficients of 50, 70, 95 and 120 are shown in Figures 4.29, 4.30, 4.31 and 4.32, respectively. The South Slough model does not appear to be very sensitive to changes in the Chezy coefficient. A Chezy coefficient of 70 appeared reasonable and was chosen for the remaining calibration simulations. Due to lack of confidence in the datum of the monitoring station and the model geometry datum (defined as the elevation of the top of the KMAX cell), datums of $-5.34,-5.49$, and -5.64 were modeled and shown in 
Figures $4.33,4.34$ and 4.35 respectively. Modeled surface water elevations still were higher than measured elevations. Storage in a diked area and in the channel upstream of Hinch Road Bridge may have been occurring, so cell widths around the Hinch Road Bridge were increased by $40 \%$ to simulate an increase in storage. No significant change in modeled surface water elevations were seen (see Figure 4.36).

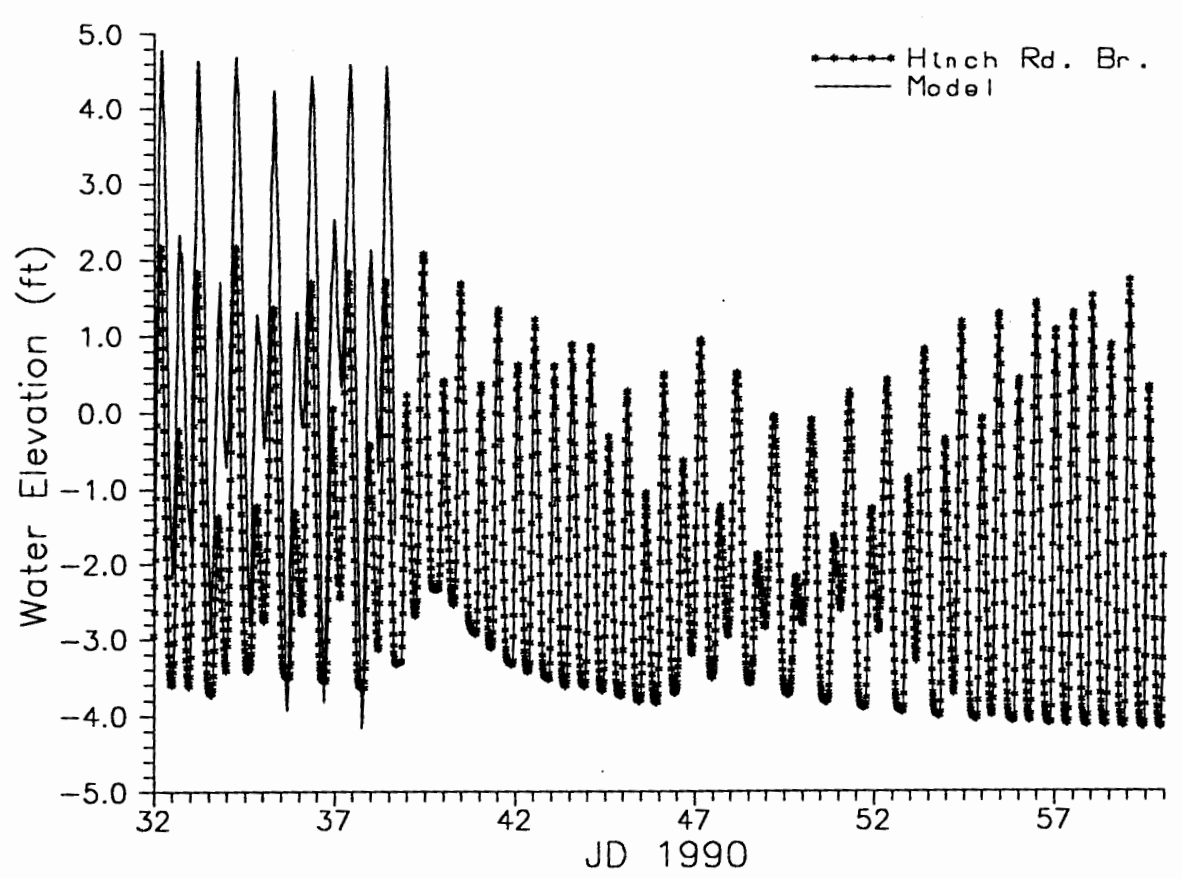

FIGURE 4.29 Model vs Hinch Rd Br Water Surface Elevations

Datum $=-5.49$, Chezy $=50$ 


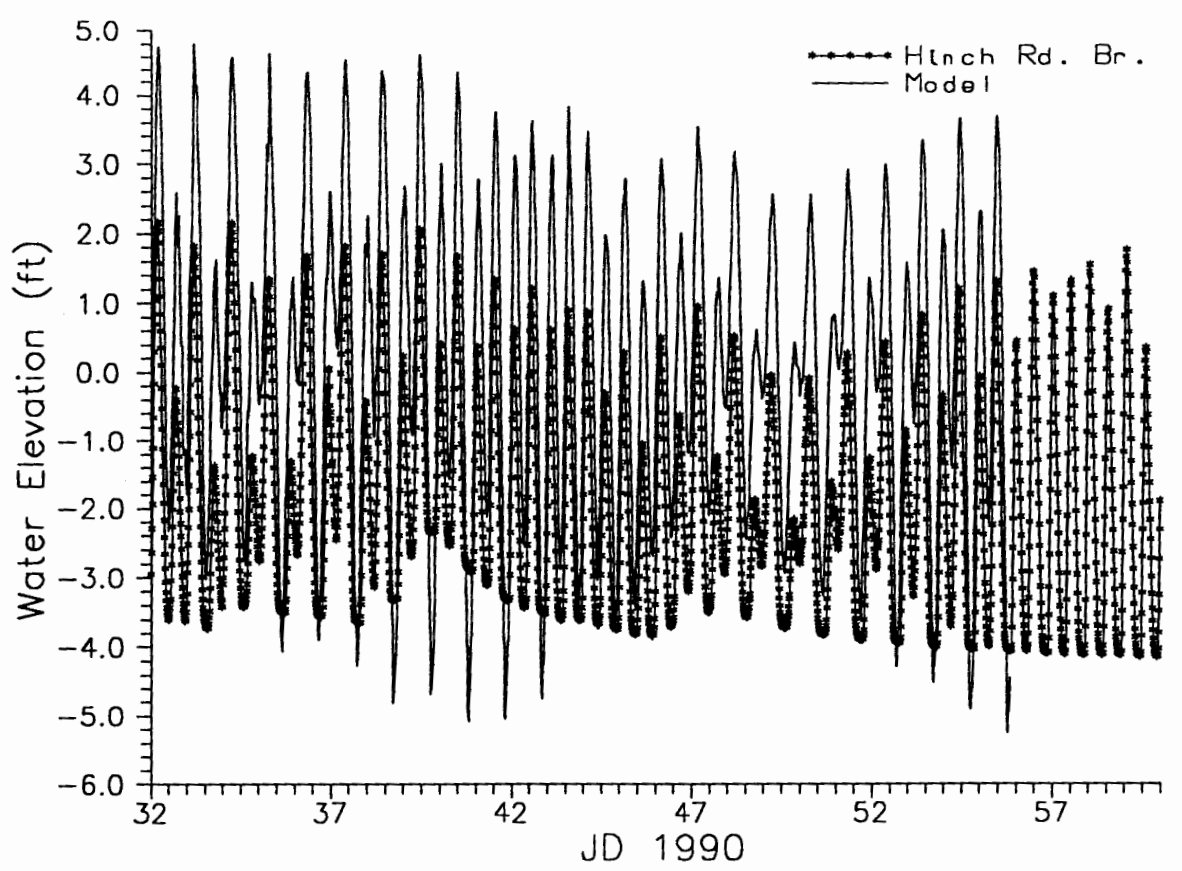

FIGURE 4.30 Model vs Hinch Rd Br. Water Surface Elevations Datum $=-5.49$, Chezy $=70$

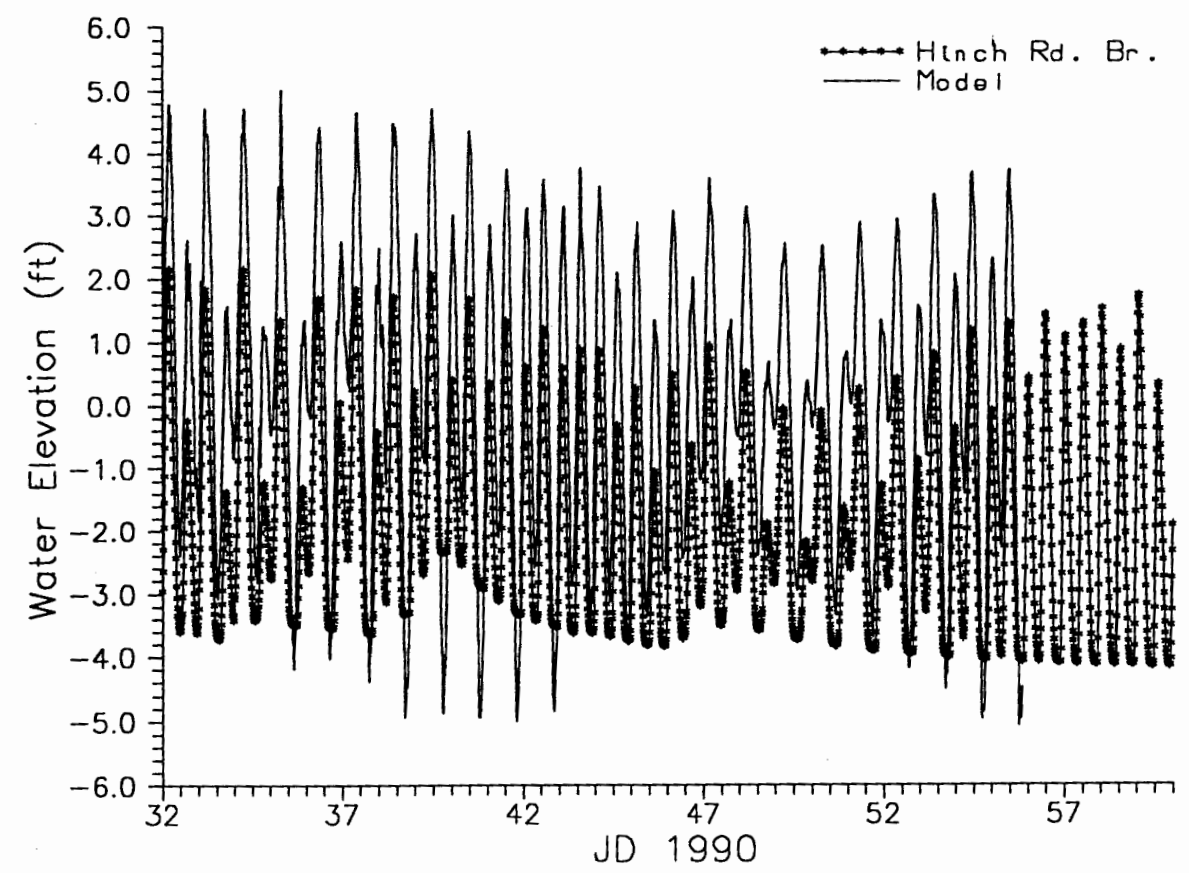

FIGURE 4.31 Model vs Hinch Rd. Br. Water Surface Elevations Datum $=-5.49$, Chezy $=95$ 


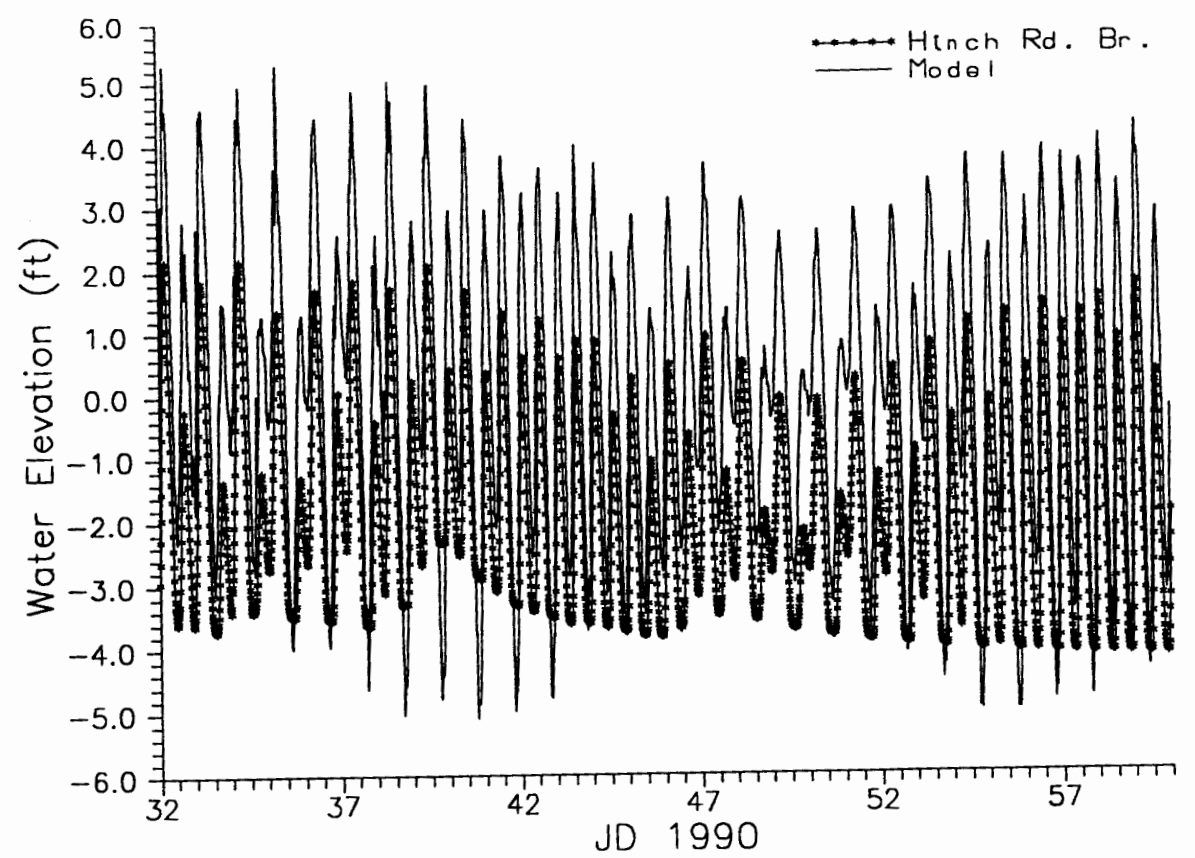

FIGURE 4.32 Model vs Hinch Rd. Br. Water Surface Elevations Datum $=-5.49$, Chezy $=120$

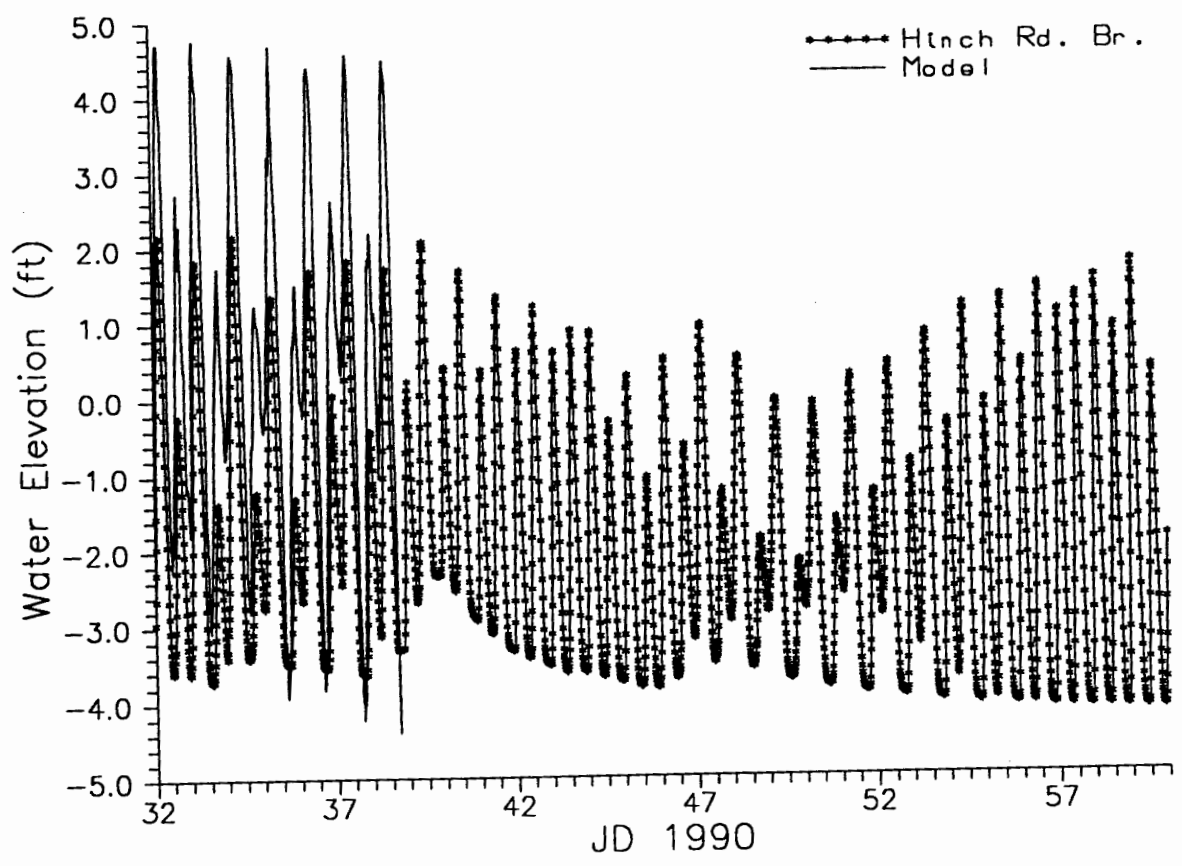

FIGURE 4.33 Model vs Hinch Rd. Br. Water Surface Elevations Datum $=-5.34$, Chezy $=70$ 


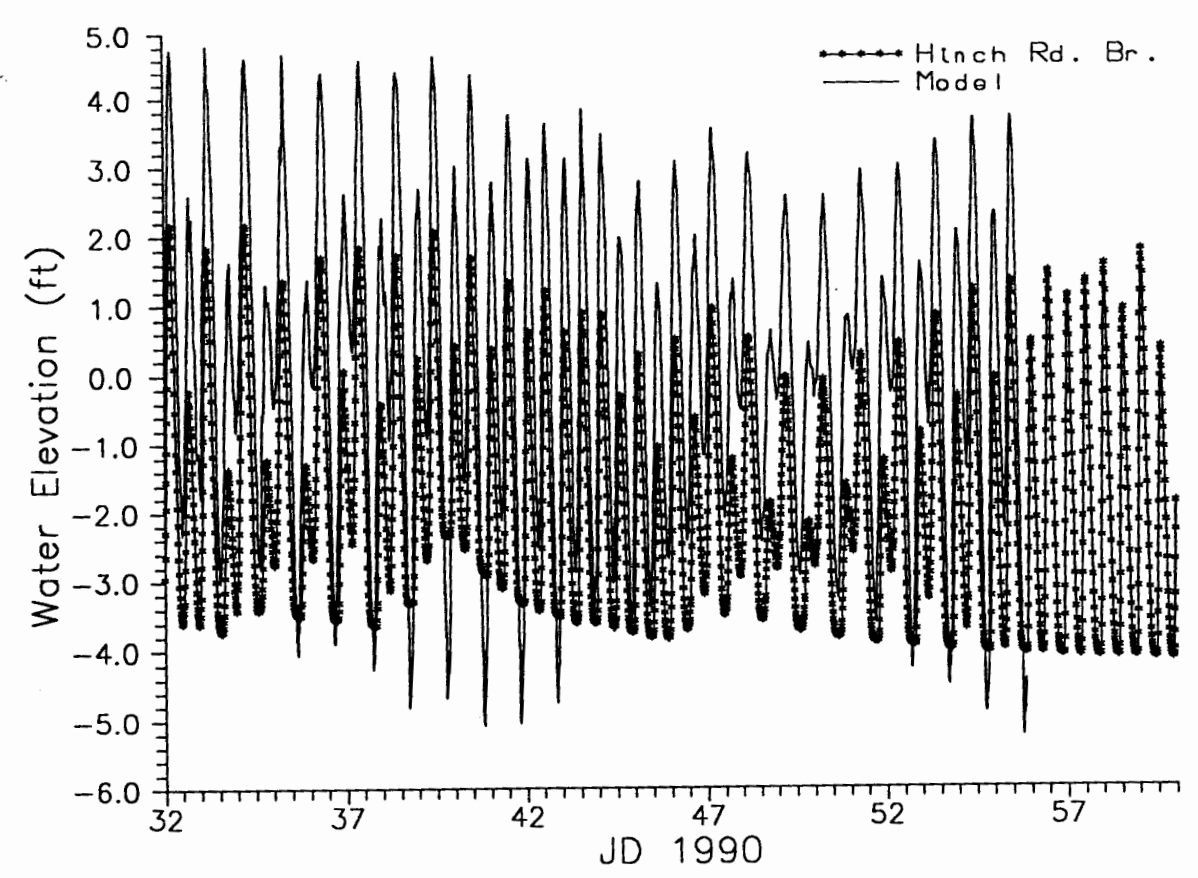

FIGURE 4.34 Model vs Hinch Rd. Br. Water Surface Elevations Datum $=-5.49$, Chezy $=70$

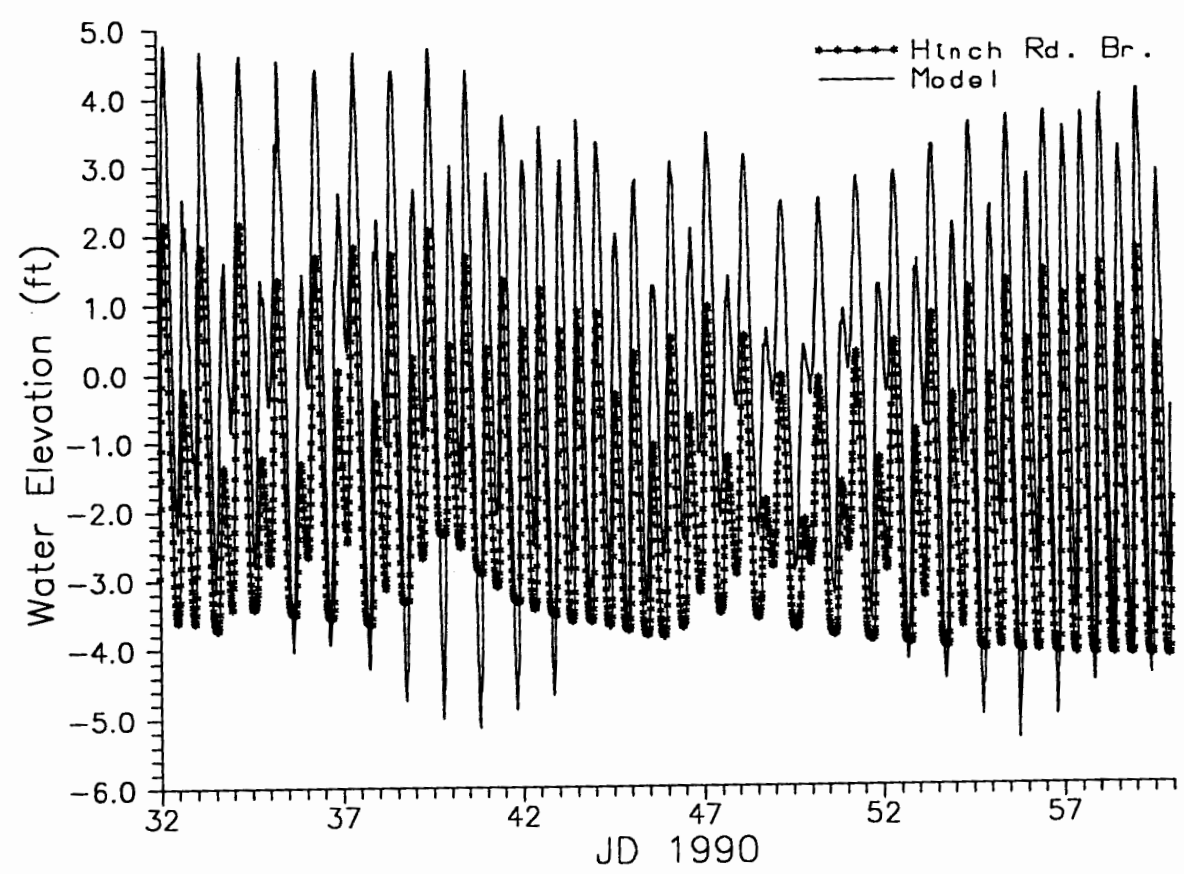

FIGURE 4.35 Model vs Hinch Rd. Br. Water Surface Elevations Datum $=-5.64$, Chezy $=70$ 


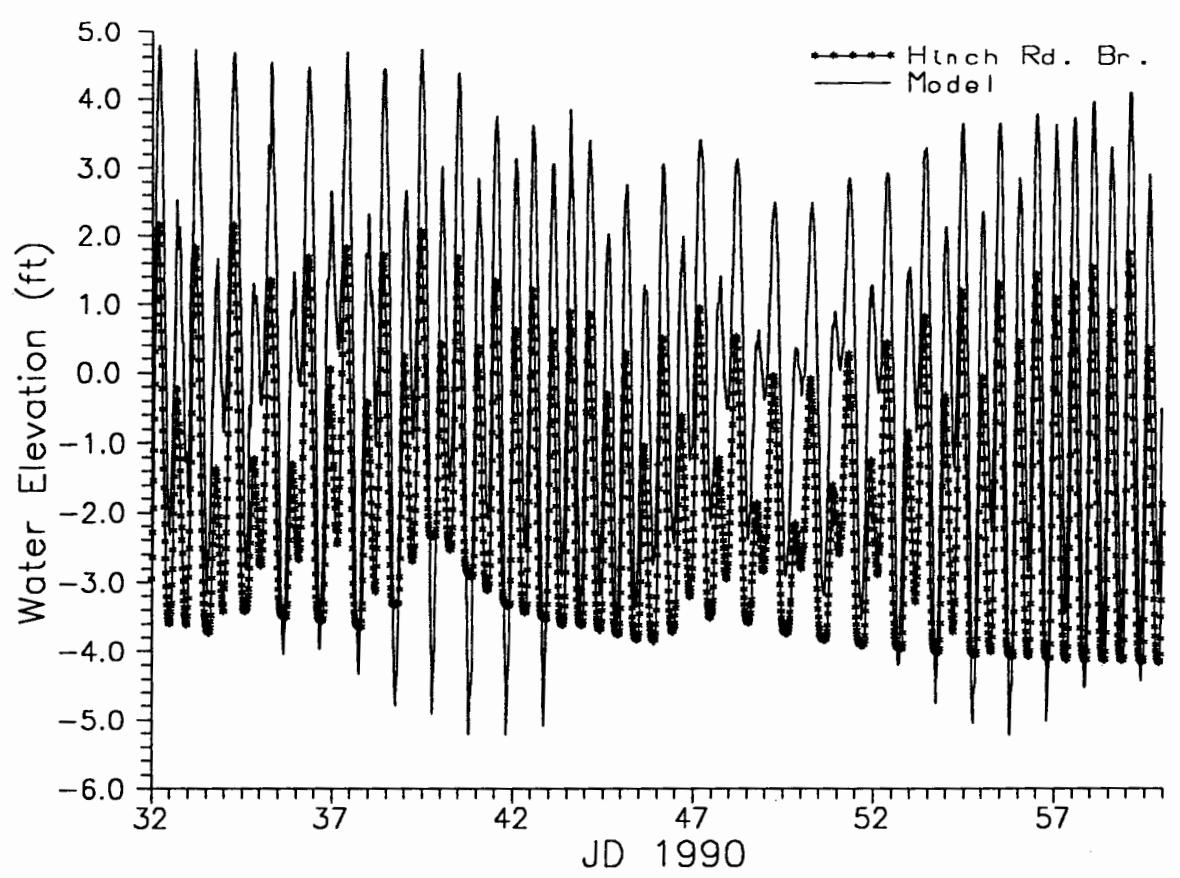

FIGURE 4.36 Model vs Hinch Rd. Br. Water Surface Elevations Datum $=-5.64$, Chezy $=70$, Increase Cell Width by $40 \%$

The possibility of suspect data was examined. Figure 4.37 shows the water elevations of the Charleston Harbor, Hinch Road Bridge and the S4 current meter during part of the simulation period. If the flow was unrestricted the hydraulic grade line across the South Slough would level out and the peak water surface elevations would almost match at each of these measurement locations but with a time lag. Comparing the measured peak water elevation at Charleston Harbor to the S4 current meter measurement, the S4 meter measured a water surface value approximately 1 foot lower. At the Hinch Road bridge station the water level was 3 feet lower. An obstacle that holds flow back is a possible explanation for the inaccurate readings at the Hinch Road Bridge station. The timing for peak water elevations at Hinch Road Bridge and the S4 current meter appears not to agree with the tidal data at Charleston Harbor. A close evaluation of tidal height data on Julian day 32 and 58 is shown in Figures 4.38 and 4.39, respectively. The peak at Hinch Road Bridge and north of Valino Island was slightly before the peak at Charleston Harbor. Since tidal effects would occur at Charleston Harbor first, this was not possible. 


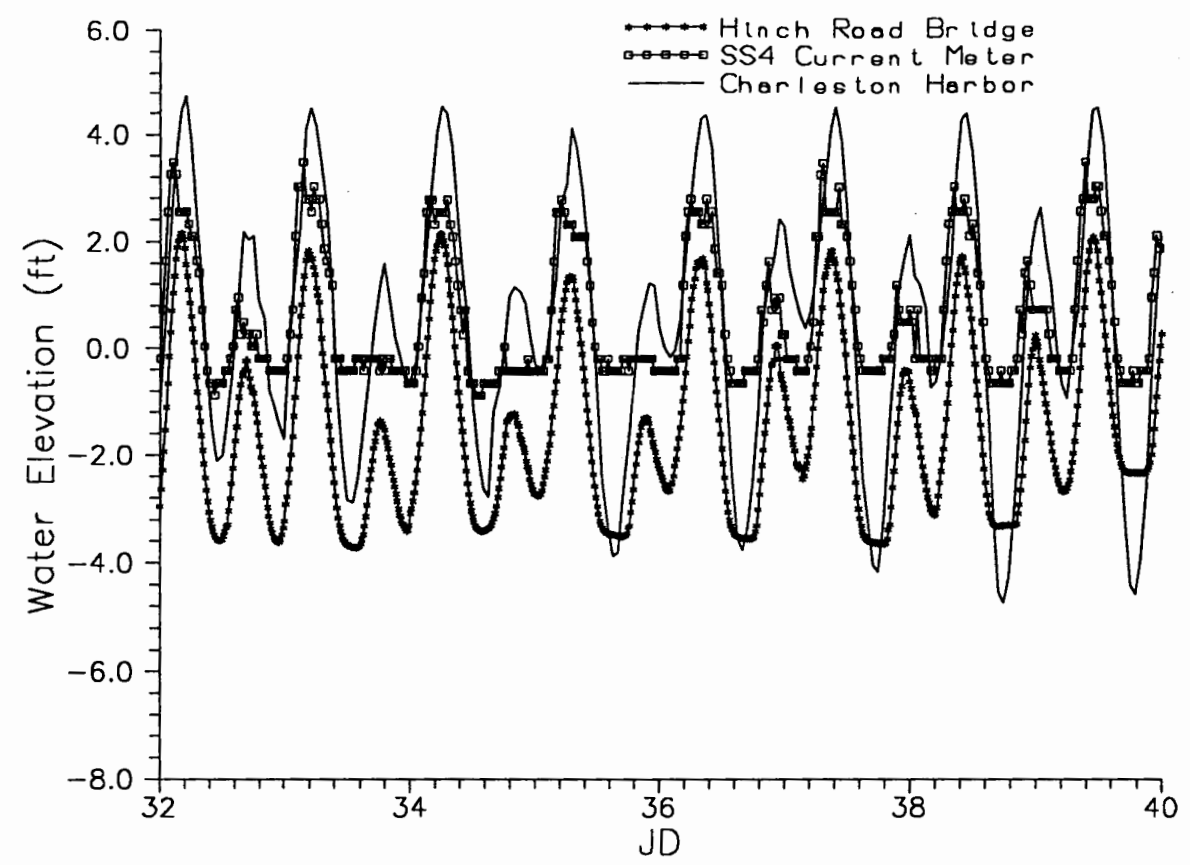

FIGURE 4.37 Water Surface Elevations at Monitoring Sites

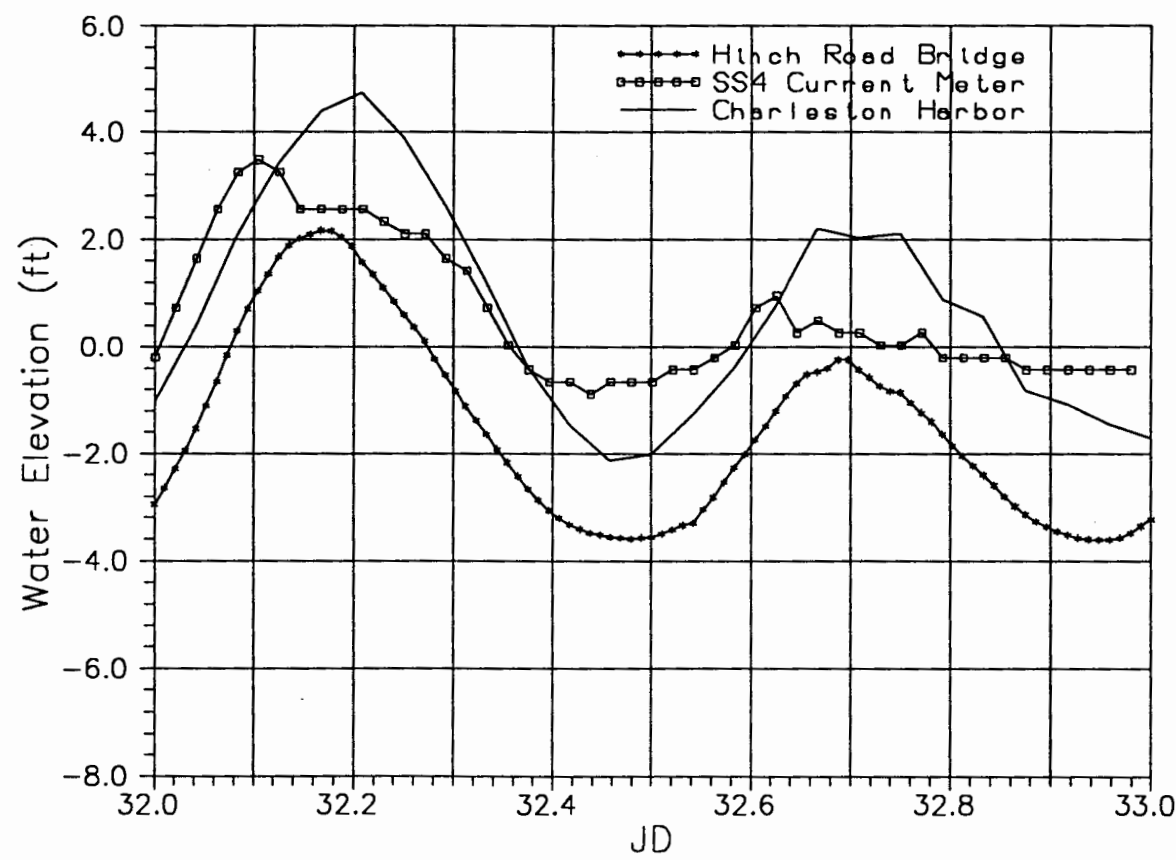

FIGURE 4.38 Water Elevations at Monitoring Sites, Julian Day 32 


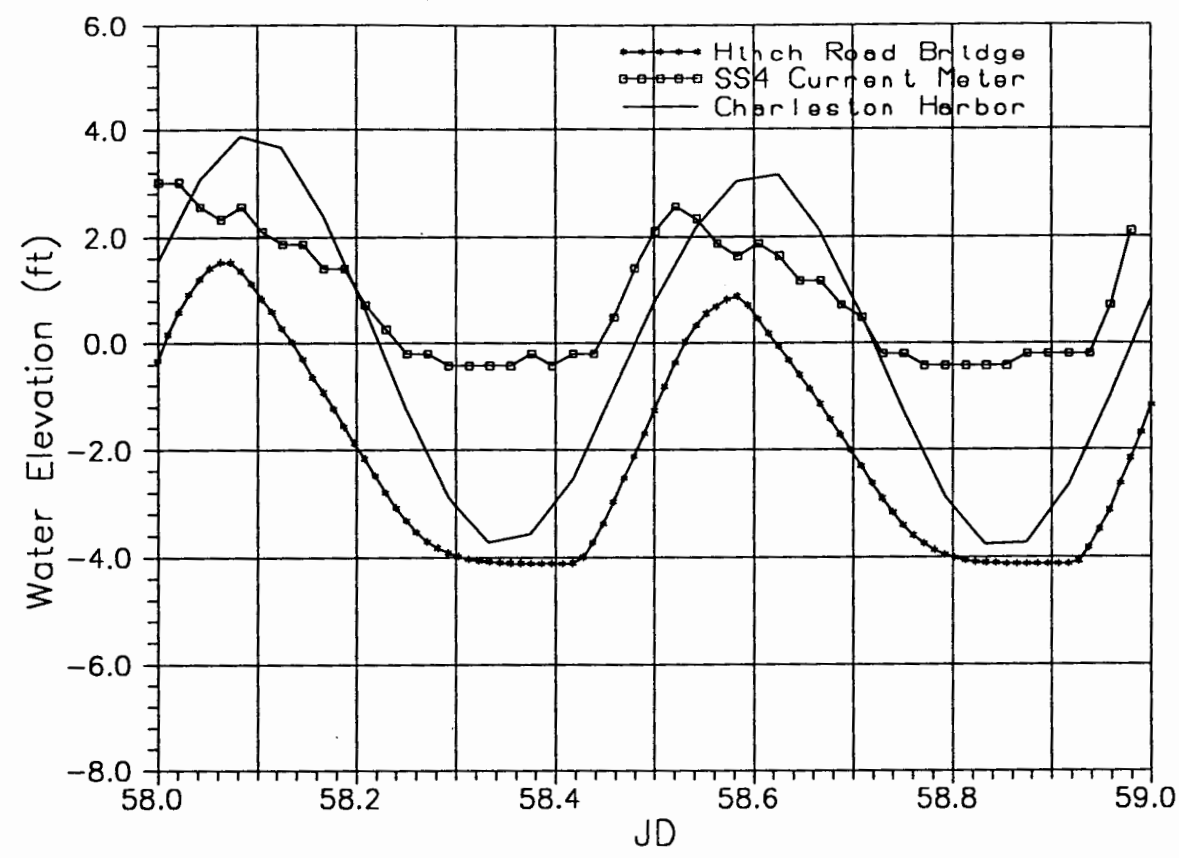

FIGURE 4.39 Water Surface Elevations at Monitoring Sites, Julian Day 58

The timing of the measured peak high water elevation at the S4 Current meter agreed with model predictions. The measured peak high water elevations are lower than the model predictions (see Figure 4.40). The S4 current meter water surface elevations are approximate and are accurate within a foot or two of the actual measurement. A datum of -5.64 yielded the best model predictions.

Velocities measured at the S4 current meter for datum $=-5.64$ and Chezy $=70.0$, match predicted model data well as shown in Figure 4.41. 


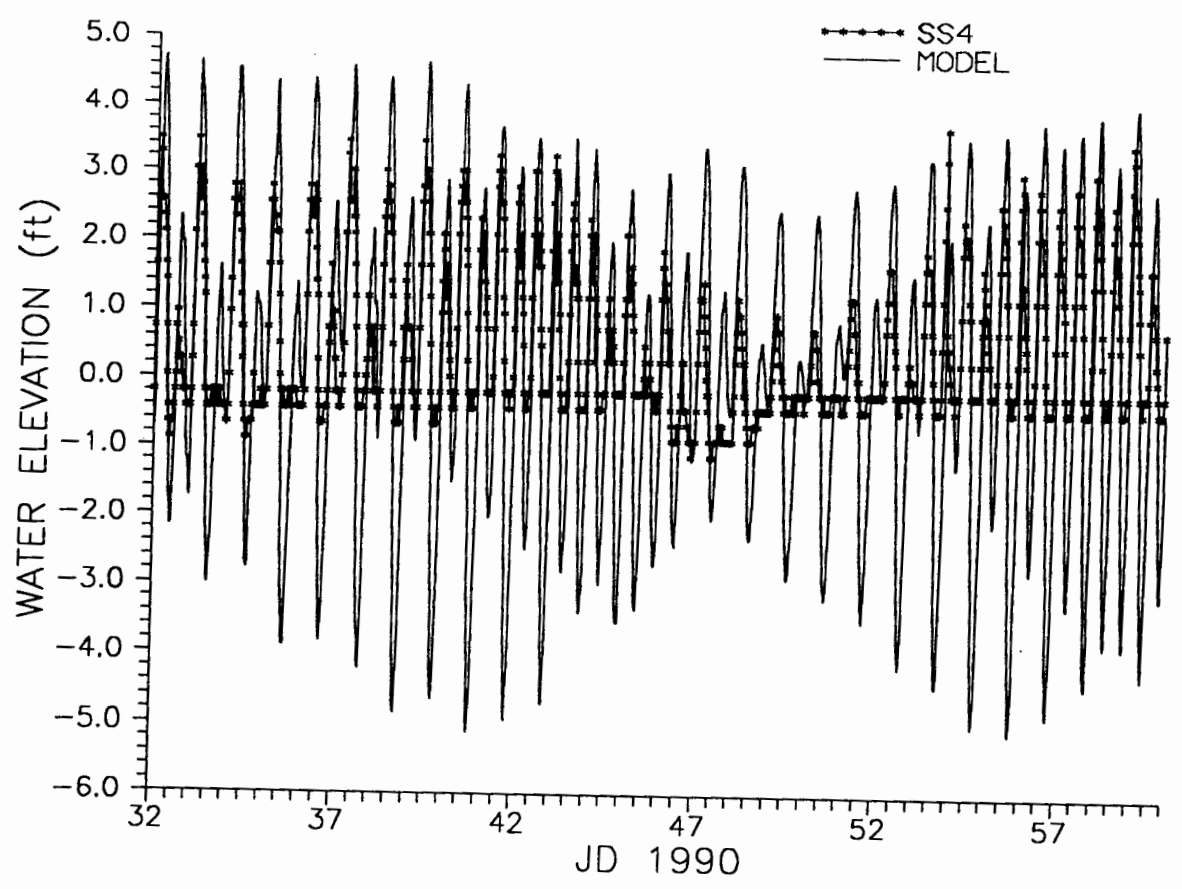

FIGURE 4.40 Model vs S4 Water Surface Elevations Datum $=-5.64$, Chezy $=70.0$

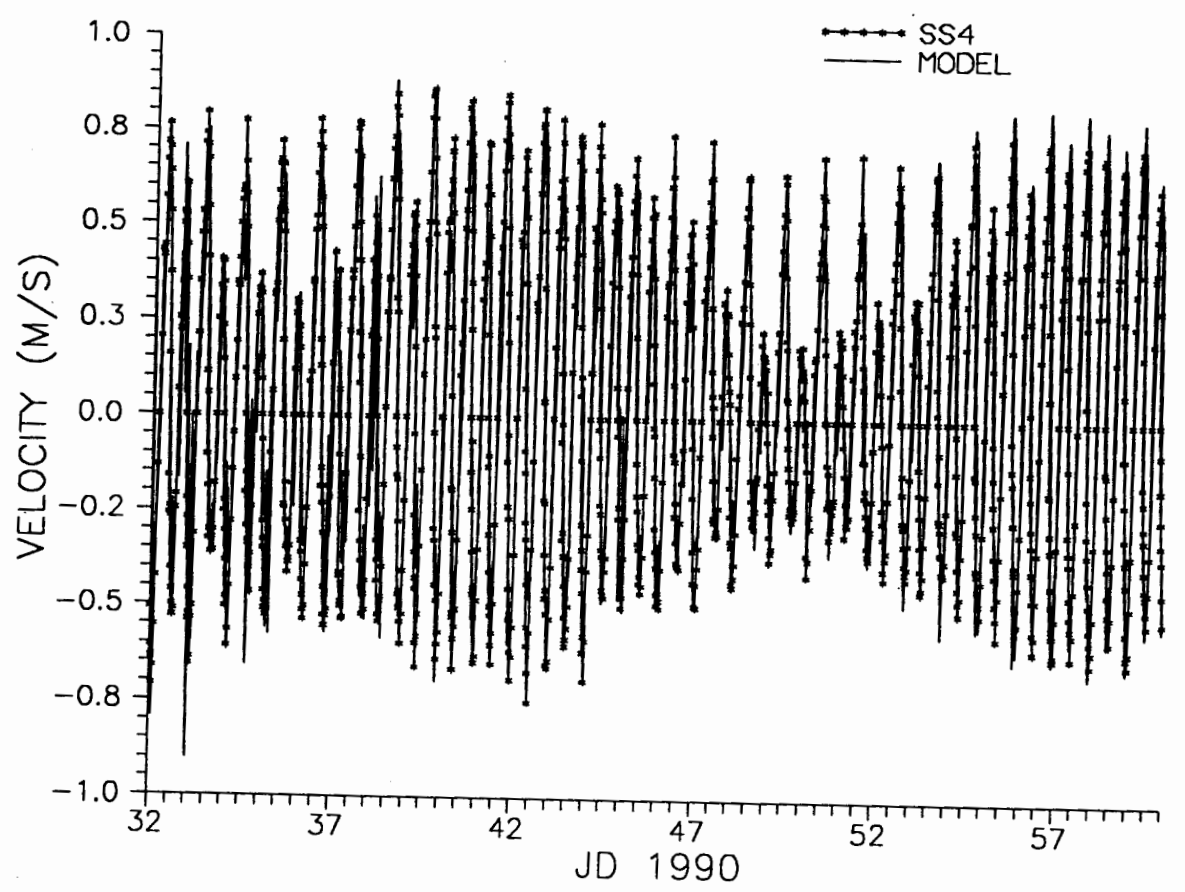

FIGURE 4.41 Model vs S4 Velocity Datum $=-5.64$, Chezy $=70$ 


\section{Temperature}

Model output was compared to temperature measured at the S4 current meter. No measurements of inflow temperatures were available so initial inflow temperature was set at a constant $5.5^{\circ} \mathrm{C}$ for all six inflow locations during the calibration period. Modeled temperature predictions were lower than measured temperature values, see Figure 4.42. Inflow temperatures were raised to $11.5{ }^{\circ} \mathrm{C}$, see Figure 4.43 . Modeled temperature predictions were still low during the later half of the calibration period than the measured temperature values. Sensitivity of air temperature was examined. Low and high temperatures collected at the North Bend weather station were compared to temperature collected at the weather station near Winchester Creek, see Figure 4.44. The North Bend station had lower low temperatures than the Winchester Creek station for some time periods during the simulation period. These adjustments were made in the input meteorological file, changing both air temperature and dew point, and no significant change in modeled water temperature was observed.

Julian day 53 to 60 corresponded to a period with little or no rain as shown in Figure 4.21. Increasing the inflow temperature would have no effect on temperature during periods with no rain. One assumption that had been made was that there was no base flow. Since inflows would be warmer than flows attributed to the ocean a base flow was added. Figures 4.45 and 4.46 show model runs for base flow of $1 \mathrm{~m}^{3} / \mathrm{s}$ and $2 \mathrm{~m}^{3} / \mathrm{s}$ respectively. The modeled temperature was still low for Julian day 53 to 60 . Inflows were adjusted to $13.5{ }^{\circ} \mathrm{C}$ and the results shown in Figure 4.47. Peak temperatures were now too high during the first part of the calibration and too low during the later part. The low tide temperatures were also not modeled correctly. Since the Rational Method of calculating inflows was also suspect, increasing the flow of the inflows was examined. In coordination with the calibration for total dissolved solids, discussed below, the inflows were increased in various combinations with increased base flow. Figure 4.48 shows model output for increased inflow of 3 times the original flow, and a base flow of $3 \mathrm{~m}^{3} / \mathrm{s}$. This correlated well with the dry time period, Julian day 52 to 60 .

Temperature predictions were sensitive to inflow temperatures, and these inflow temperatures were adjusted until the model output matched well with the measured temperature at the $\mathrm{S} 4$ current meter. The final inflow temperatures used are shown in Appendix B. Figure 4.49 is the final calibration graph using these inflow temperatures. 


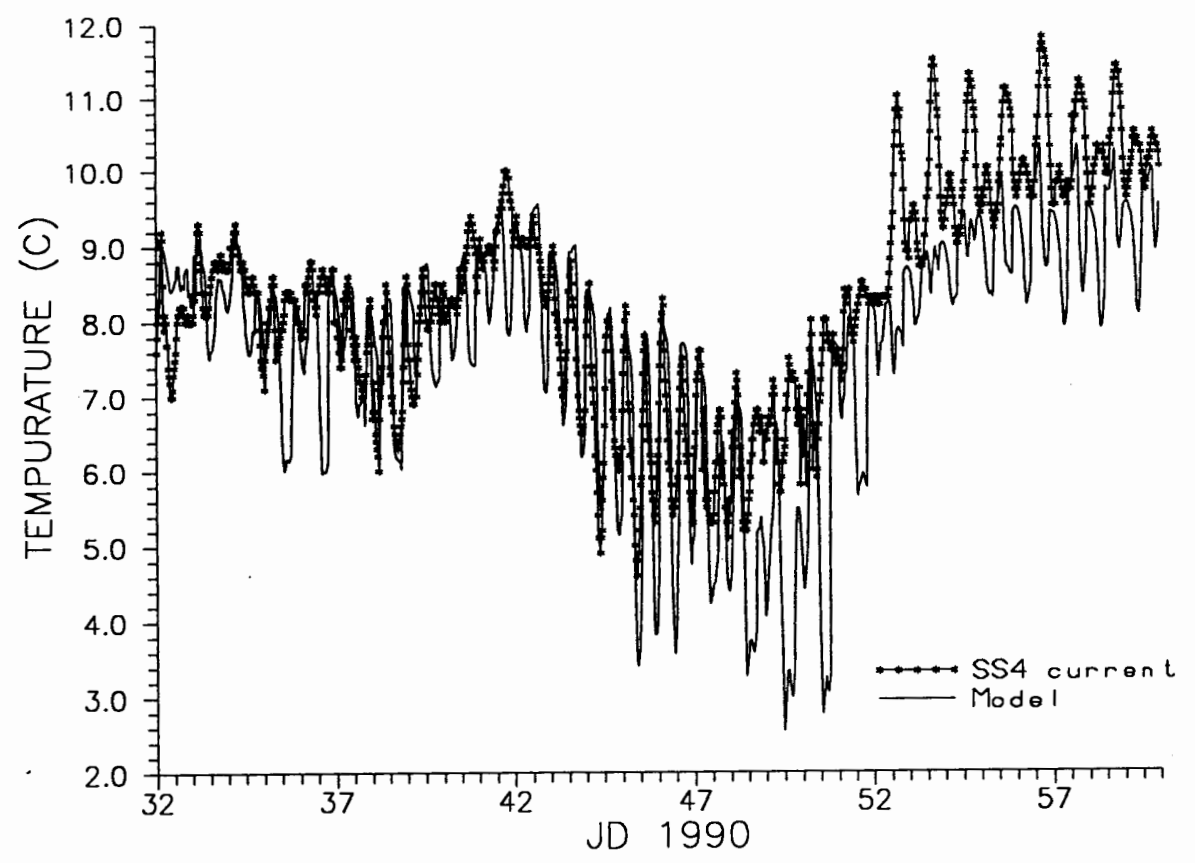

FIGURE 4.42 Model vs S4 Temperature, Inflows at $5.5^{\circ} \mathrm{C}$

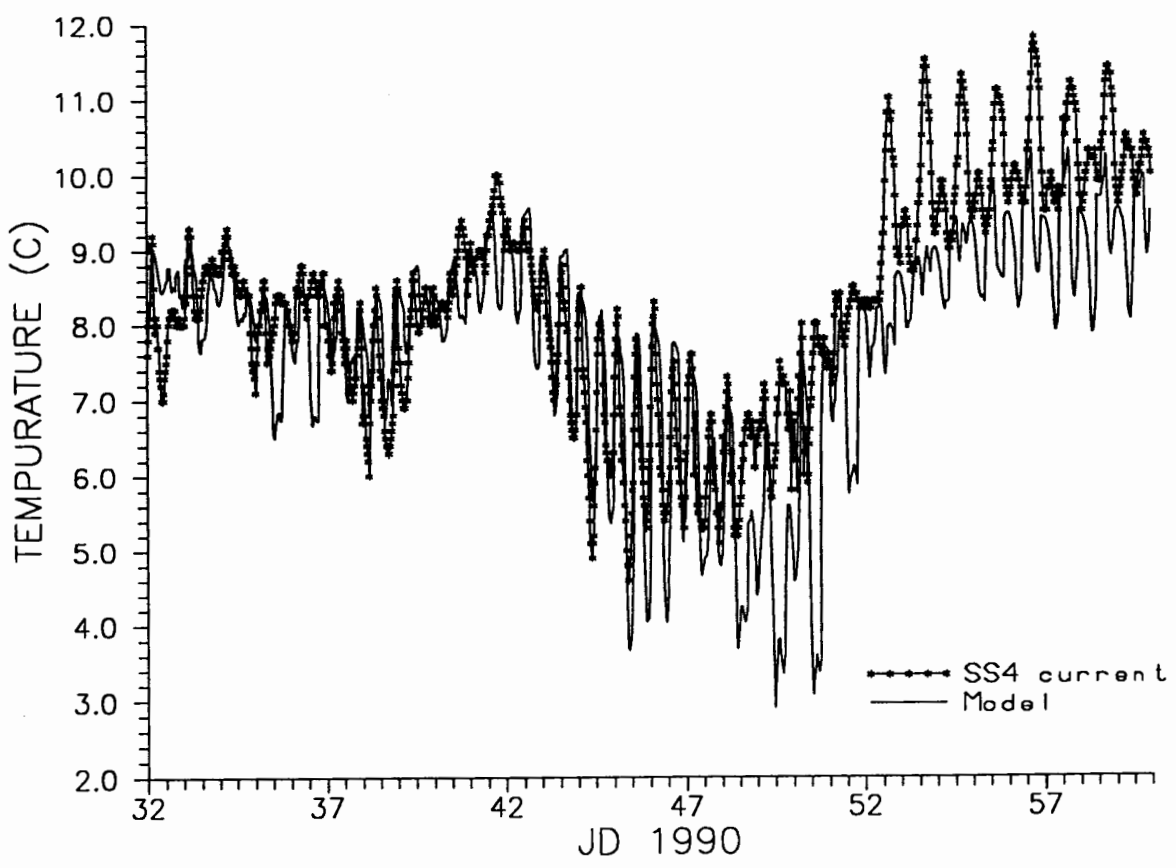

FIGURE 4.43 Model vs S4 Temperature, Inflows at $11.5^{\circ} \mathrm{C}$ 


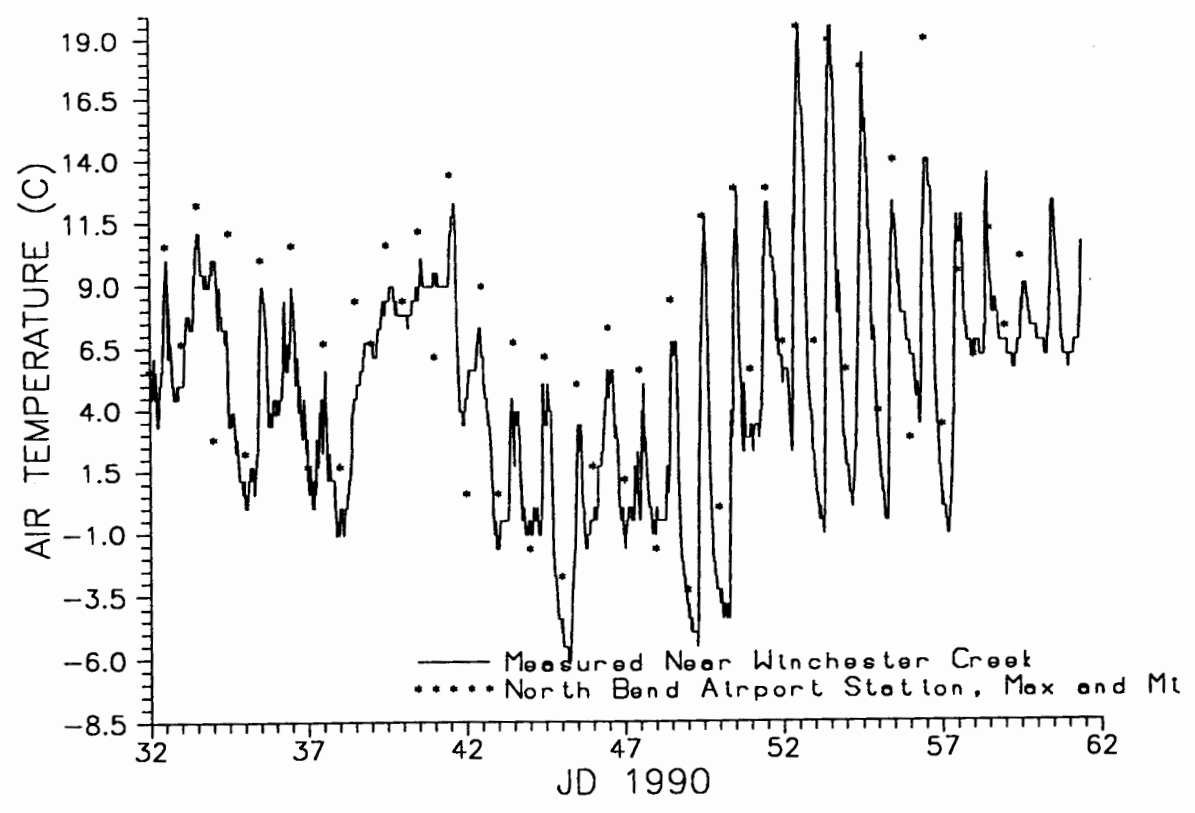

FIGURE 4.44 Air Temperature Comparison

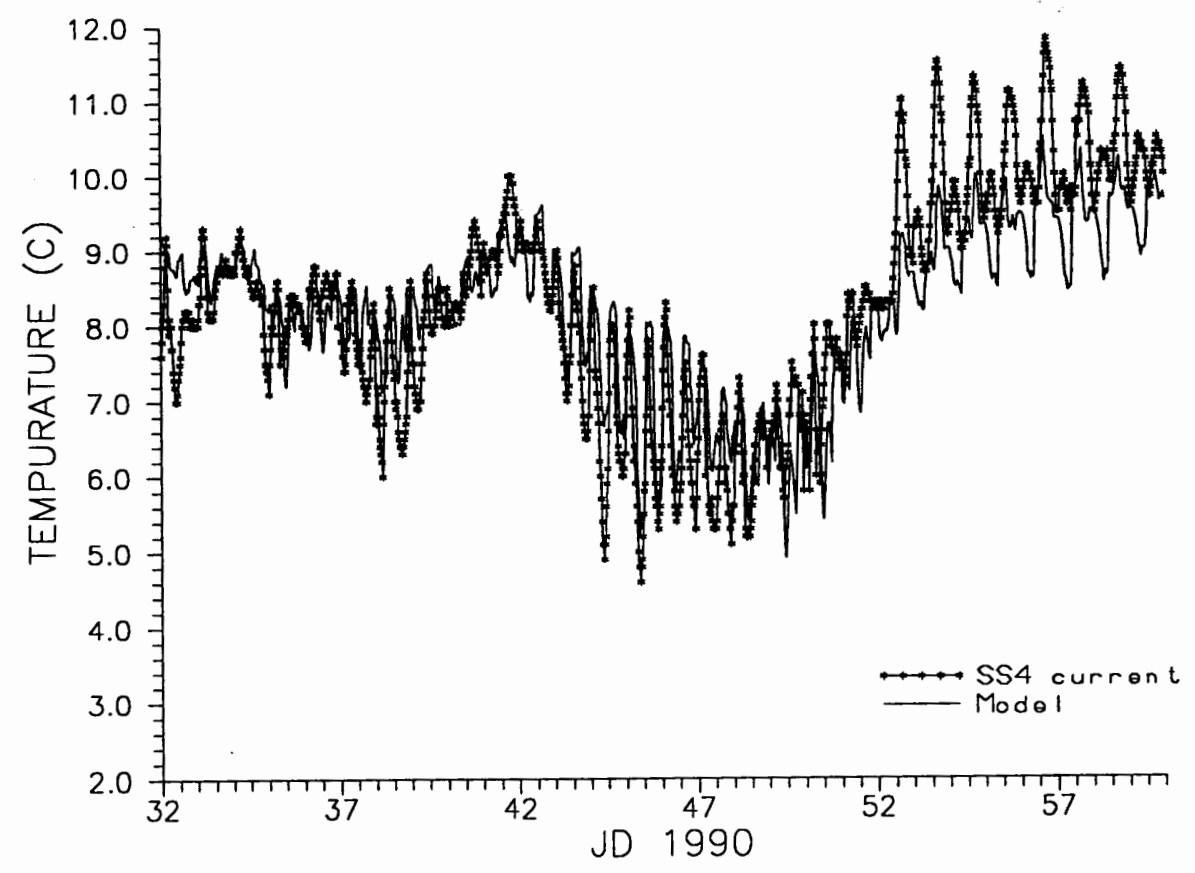

FIGURE 4.45 Model vs S4 Temperature Base Flow $=1.0 \mathrm{~m}^{3} / \mathrm{s}$, Inflow at $11.5^{\circ} \mathrm{C}$ 


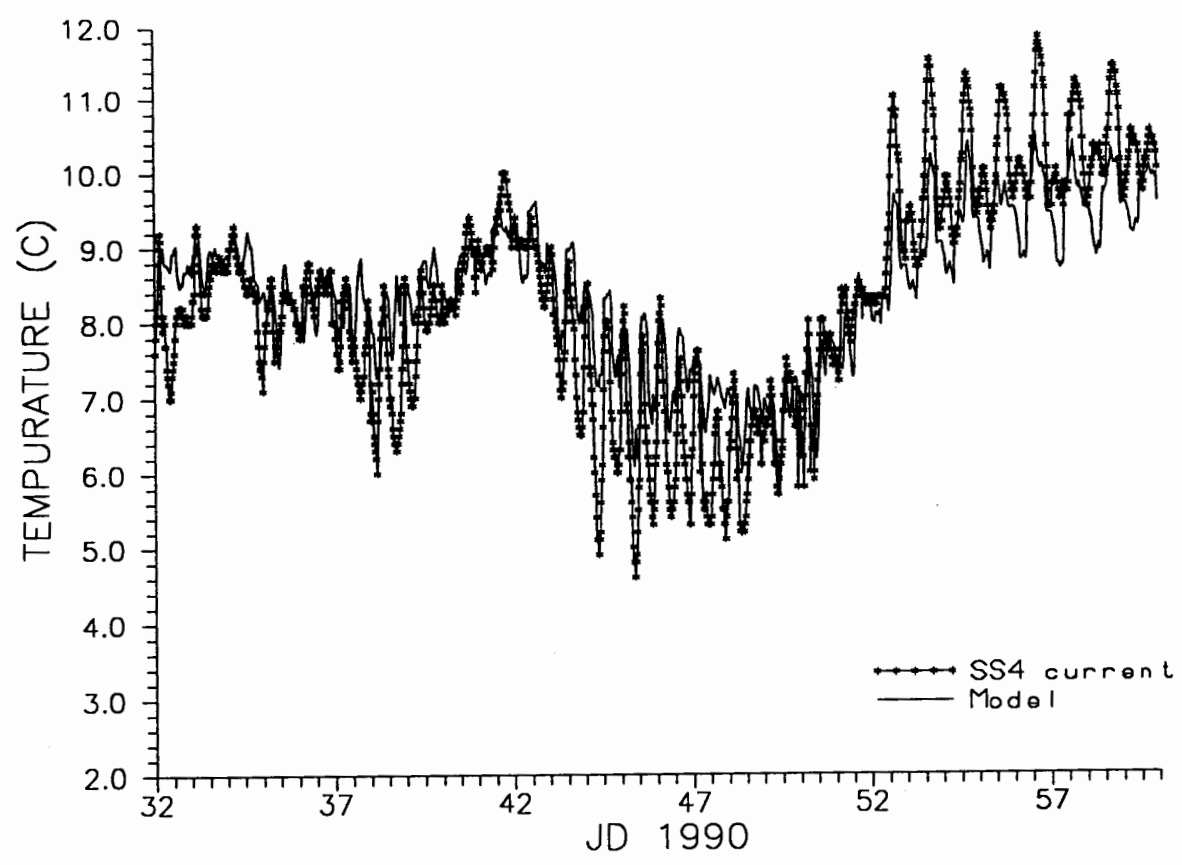

FIGURE 4.46 Model vs S4 Temperature

Base Flow $=2.0 \mathrm{~m}^{3} / \mathrm{s}$, Inflows at $11.5^{\circ} \mathrm{C}$

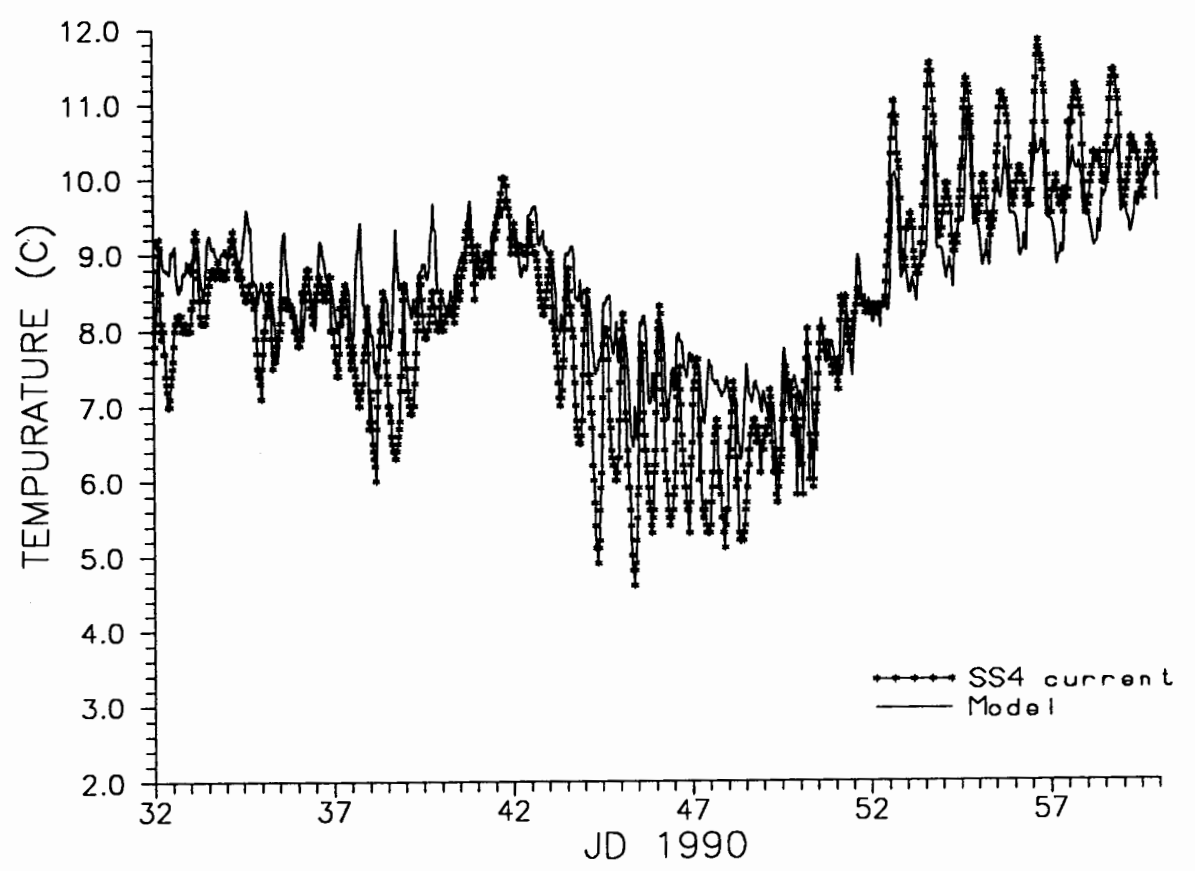

FIGURE 4.47 Model vs S4 Temperature, Inflows at $13.5^{\circ} \mathrm{C}$ 


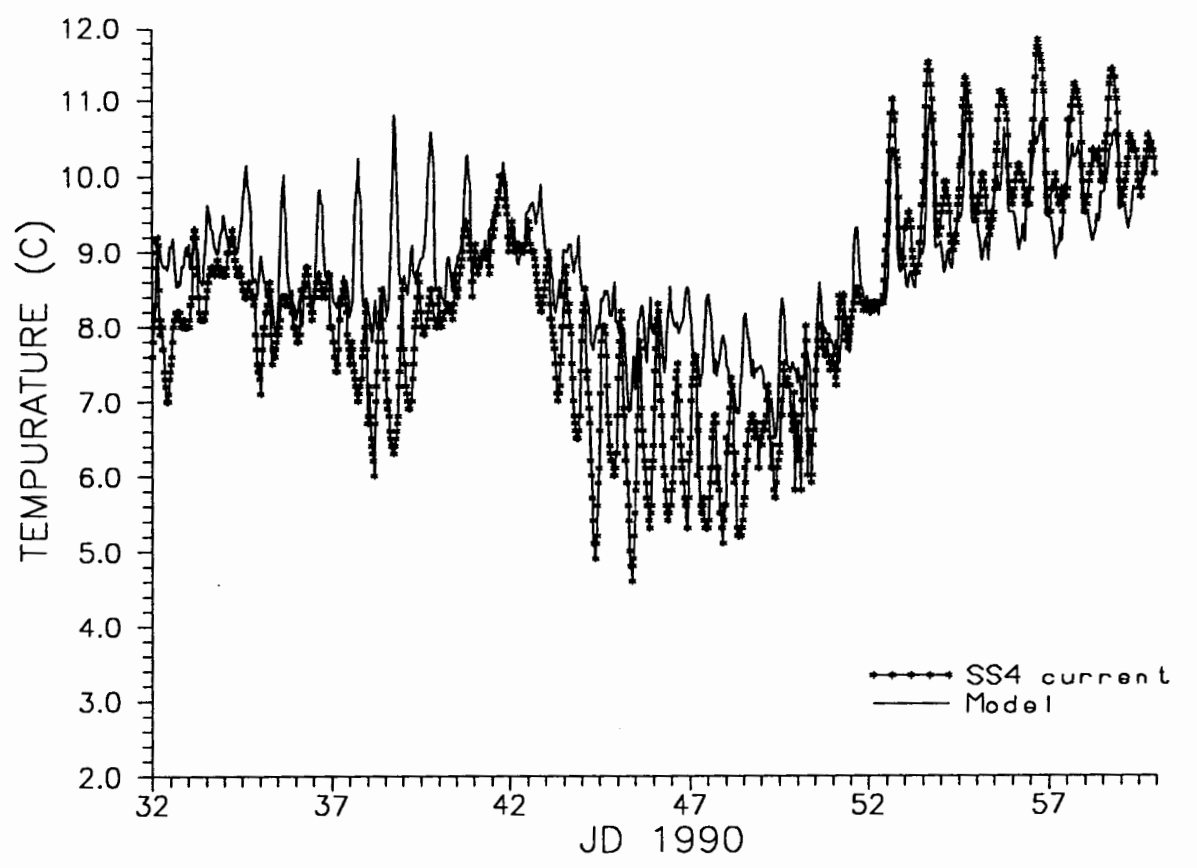

FIGURE 4.48 Model vs S4 Temperature, Inflow Temperature $=13.5^{\circ} \mathrm{C}$ 3 Times Flow, Base Flow $=3.0 \mathrm{~m}^{3} / \mathrm{s}$

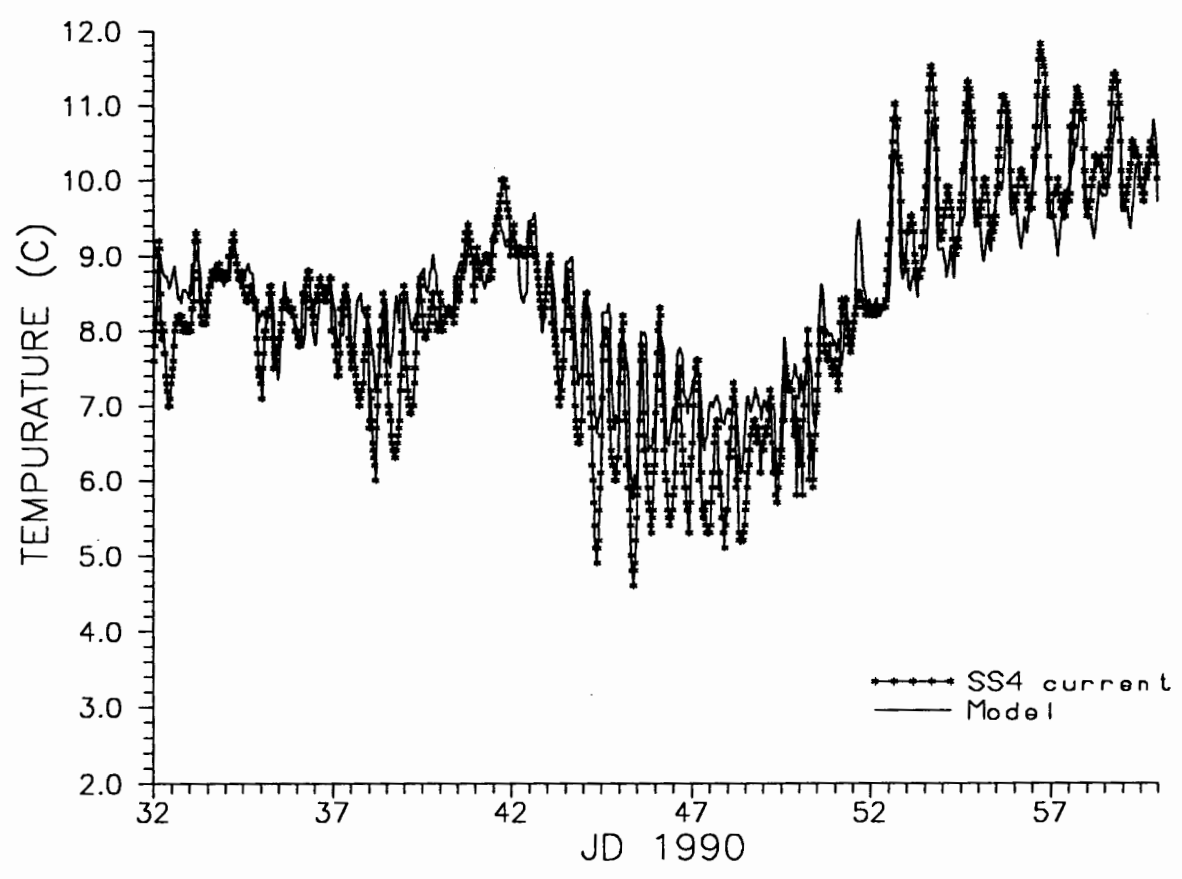

FIGURE 4.49 Model vs S4 Temperature, Varied Inflow Temperatures 3 Times Flow, Base Flow $=3.0 \mathrm{~m}^{3} / \mathrm{s}$ 


\section{Total Dissolved Solids}

Figure 4.50 shows model predictions of TDS compared to S4 measured TDS with an initial TDS $=35,000 \mathrm{mg} / \mathrm{l}$. The measured S4 TDS was calculated from the S4 conductivity data using the TDS to conductivity correlation shown in Wells and Baird (1990). As the tide brings in salt water, the TDS increases; when the tide goes out the fresh water from inflows lowers the TDS. Initial model predictions of TDS at the S4 meter showed little variation in low and high peak values that should occur due to tidal effects. The initial TDS was lowered to $15,000 \mathrm{mg} / 1$ and base flows of $1.0 \mathrm{~m}^{3} / \mathrm{s}$ and $2.0 \mathrm{~m}^{3} / \mathrm{s}$ were added as shown in Figures 4.51 and 4.52 , respectively. Lowering the initial TDS improved the first day of the simulation. Increasing the base flow had some effect on the results most noticeably near the end of the simulation, the dry period as noted above.

Model data comparisons during low tide did not correlate well with measured data during storm periods. This was due to a lack of fresh water from inflows. Variations of increasing the inflows and increasing the base flow were examined as mentioned above. Increasing the inflow would improve the predictions of TDS compared to field data only during the rainy period. Increasing the base flow would improve the predictions of TDS data during both rainy and dry periods. The increase in inflow was held constant at two times the original estimated flow, then the base flow was increased until predicted data correlated well with measured data during the dry period. Figures 4.53 and 4.54 show inflow increased by two times and base flow of $2 \mathrm{~m}^{3} / \mathrm{s}$ and $3 \mathrm{~m}^{3} / \mathrm{s}$, respectively. The dry period match well for a base flow of $3 \mathrm{~m}^{3} / \mathrm{s}$. Then, holding the base flow constant at $3 \mathrm{~m}^{3} / \mathrm{s}$ the inflow was increased until model results correlated well with measured data during the rainy period. Figures 4.55 and 4.56 show a base flow of $3 \mathrm{~m}^{3} / \mathrm{s}$ and an increase in inflow of 3 and 4 times respectively. Increasing the inflow from three times to four times the original estimated flow showed little change in modeled TDS and worsened the correlation of the model predictions of temperature with temperature data. An increase of three times the inflow and a base flow of $3 \mathrm{~m}^{3} / \mathrm{s}$ was chosen as the final calibration results. 


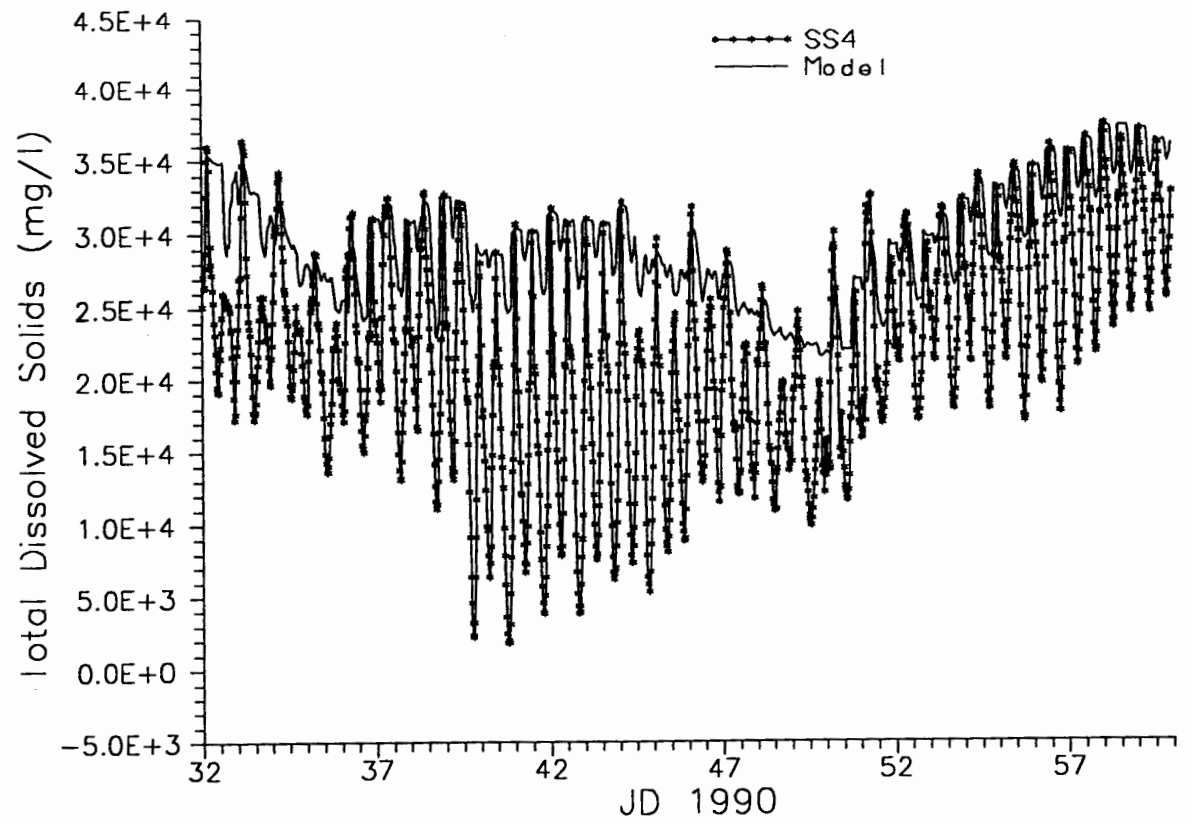

FIGURE 4.50 Model vs S4 Total Dissolved Solids, Initial TDS $=35,000 \mathrm{mg} / 1$

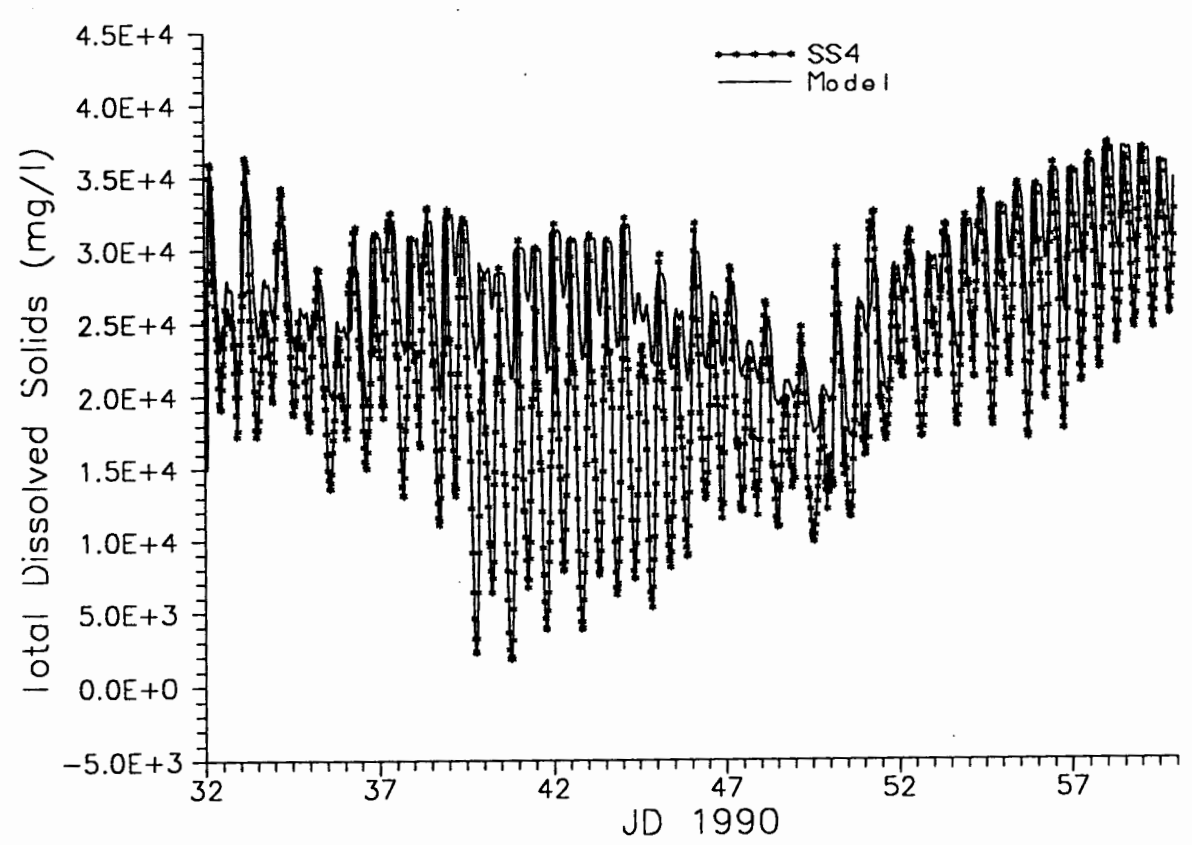

FIGURE 4.51 Model vs S4 Total Dissolved Solids Initial TDS $=15,000 \mathrm{mg} / 1$, Base Flow $=1.0 \mathrm{~m}^{3} / \mathrm{s}$ 


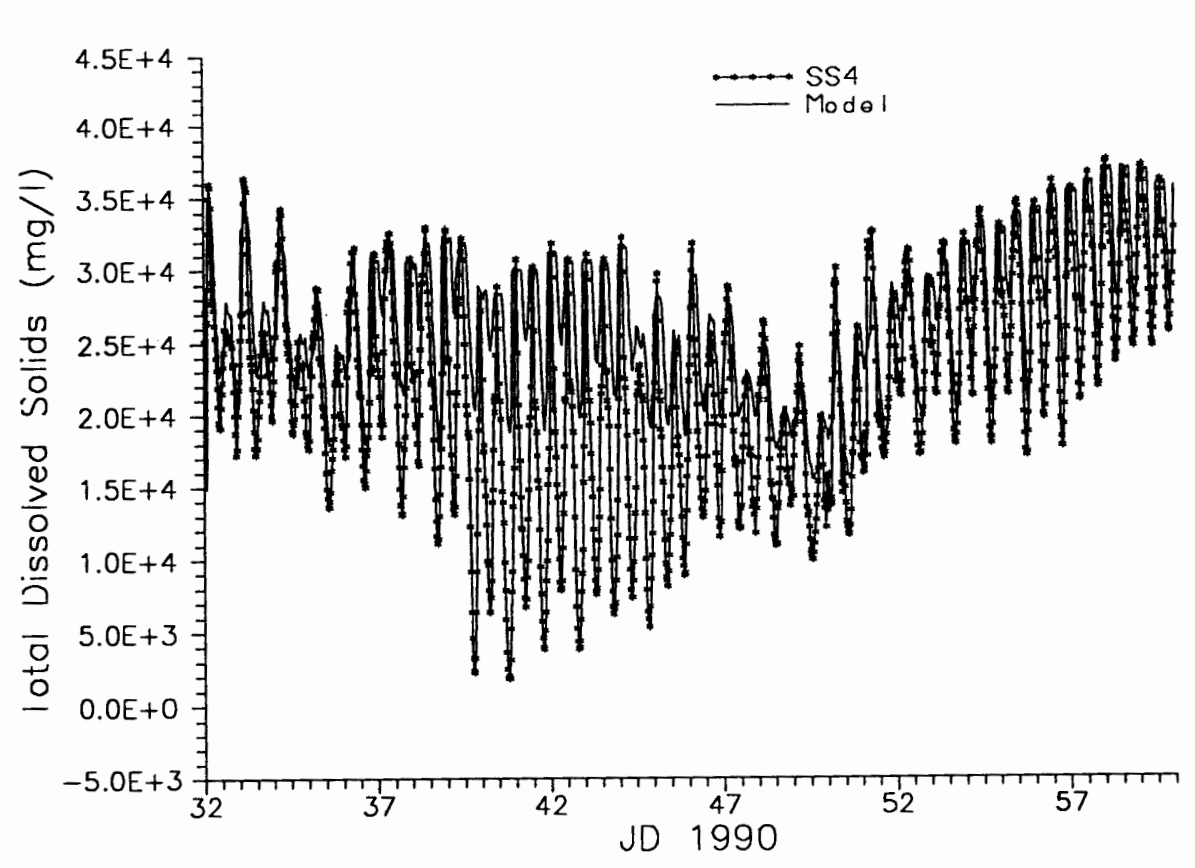

FIGURE 4.52 Model vs S4 Total Dissolved Solids Initial TDS $=15,000 \mathrm{mg} / \mathrm{l}$, Base Flow $=2.0 \mathrm{~m}^{3} / \mathrm{s}$

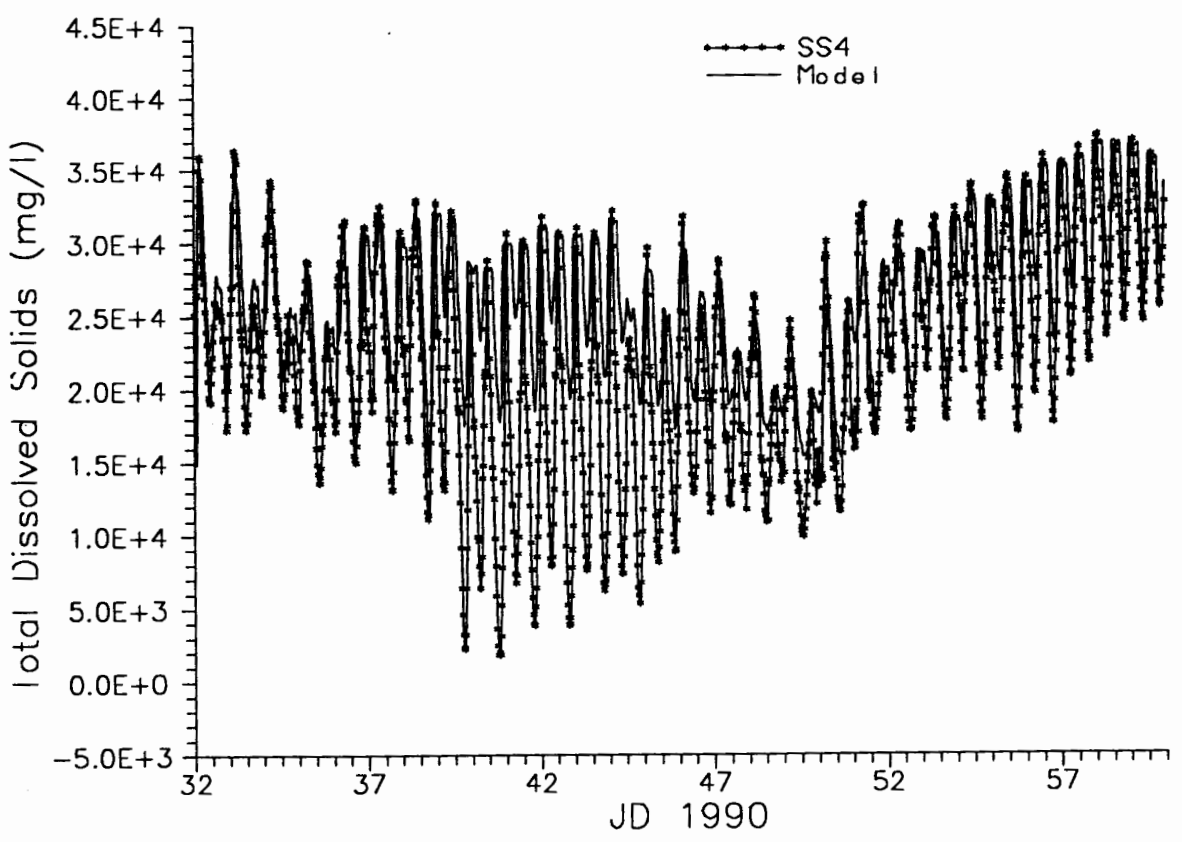

FIGURE 4.53 Model vs S4 Total Dissolved Solids Base Flow $=2.0 \mathrm{~m}^{3} / \mathrm{s}, 2$ Times Inflow 


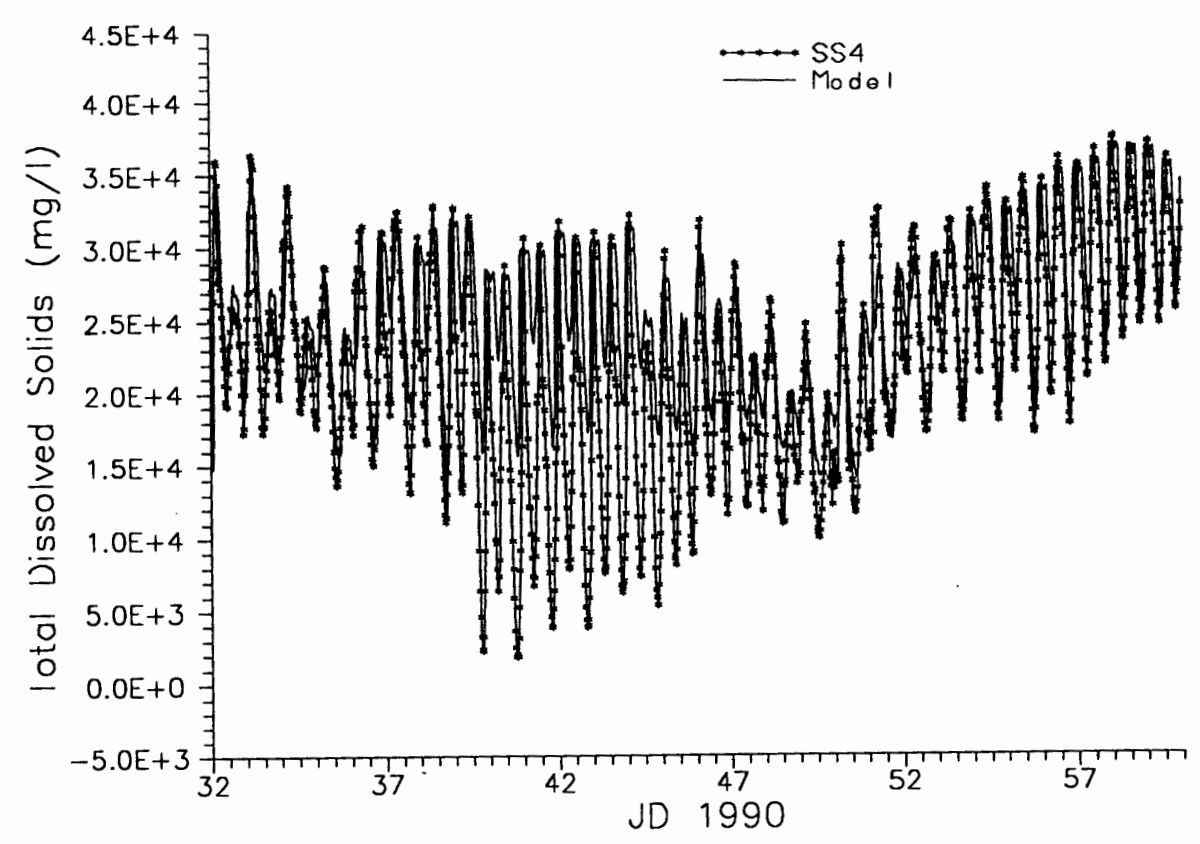

FIGURE 4.54 Model vs S4 Total Dissolved Solids Base Flow $=3.0 \mathrm{~m}^{3} / \mathrm{s}, 2$ Times Inlow

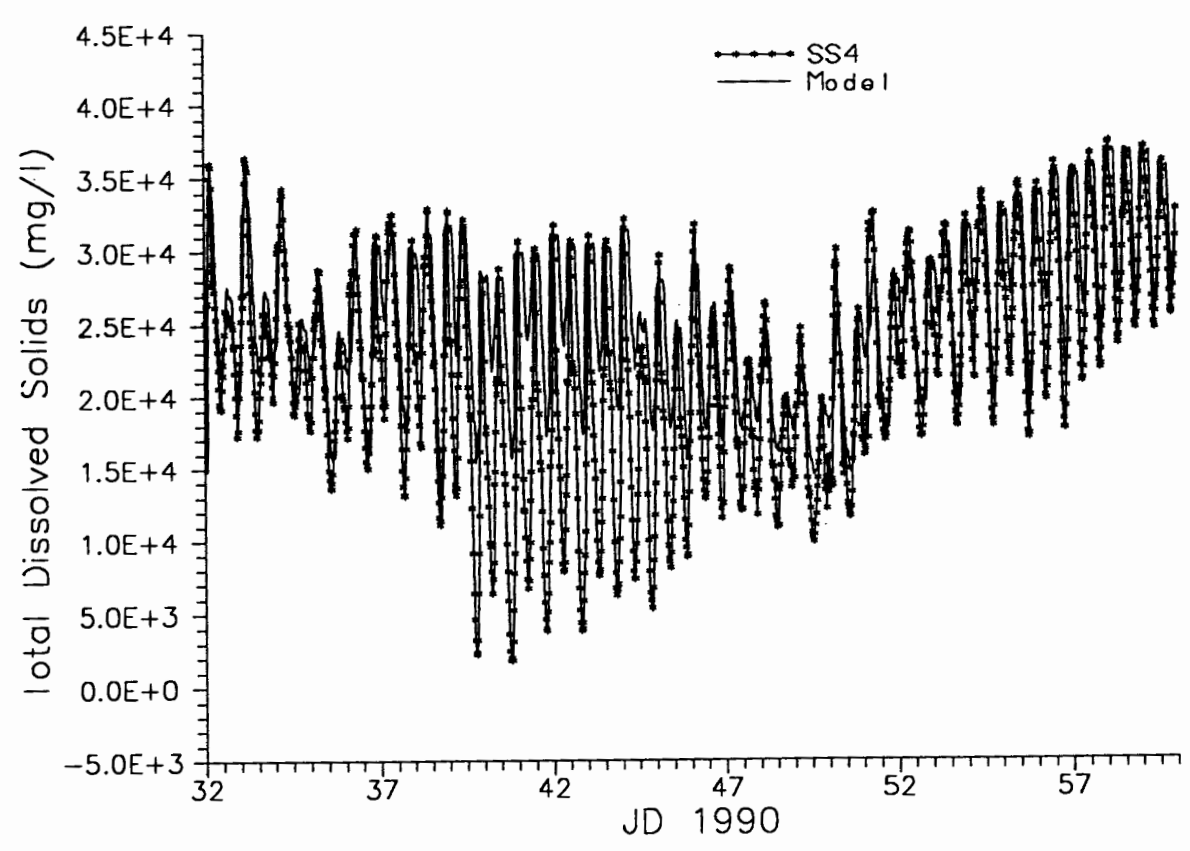

FIGURE 4.55 Model vs S4 Total Dissolved Solids Base Flow $=3.0 \mathrm{~m}^{3} / \mathrm{s}, 3$ Times Inflow 


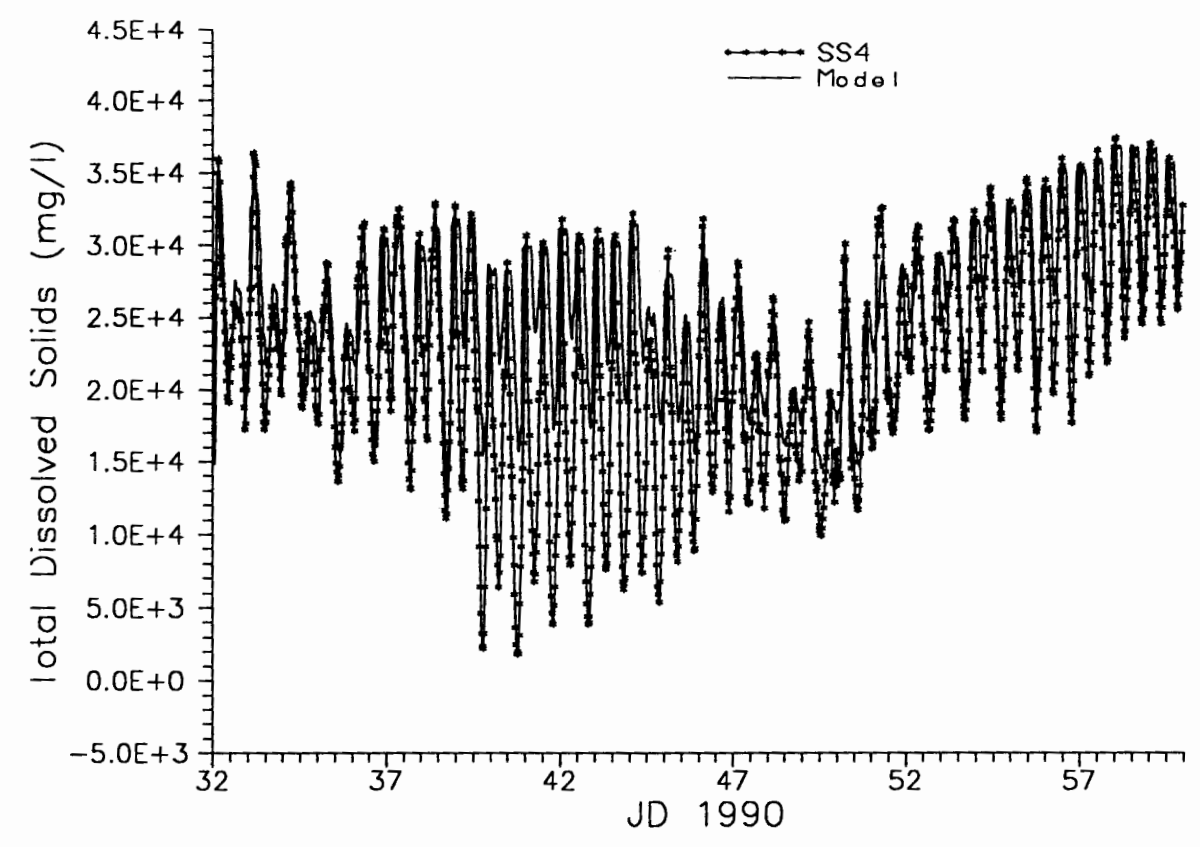

FIGURE 4.56 Model vs S4 Total Dissolved Solids

Base Flow $=3.0 \mathrm{~m}^{3} / \mathrm{s}, 4$ Times Inflow

\section{Model Calibration Summary}

Final input files are shown in Appendix B. The final calibration plots for water surface elevation at Hinch Road Bridge, water elevation at the S4 current meter, velocity at the $S 4$ current meter, temperature at the S4 current meter and TDS at the S4 current meter are shown in Figures $4.57,4.58,4.59,4.60$ and 4.61 respectively. 


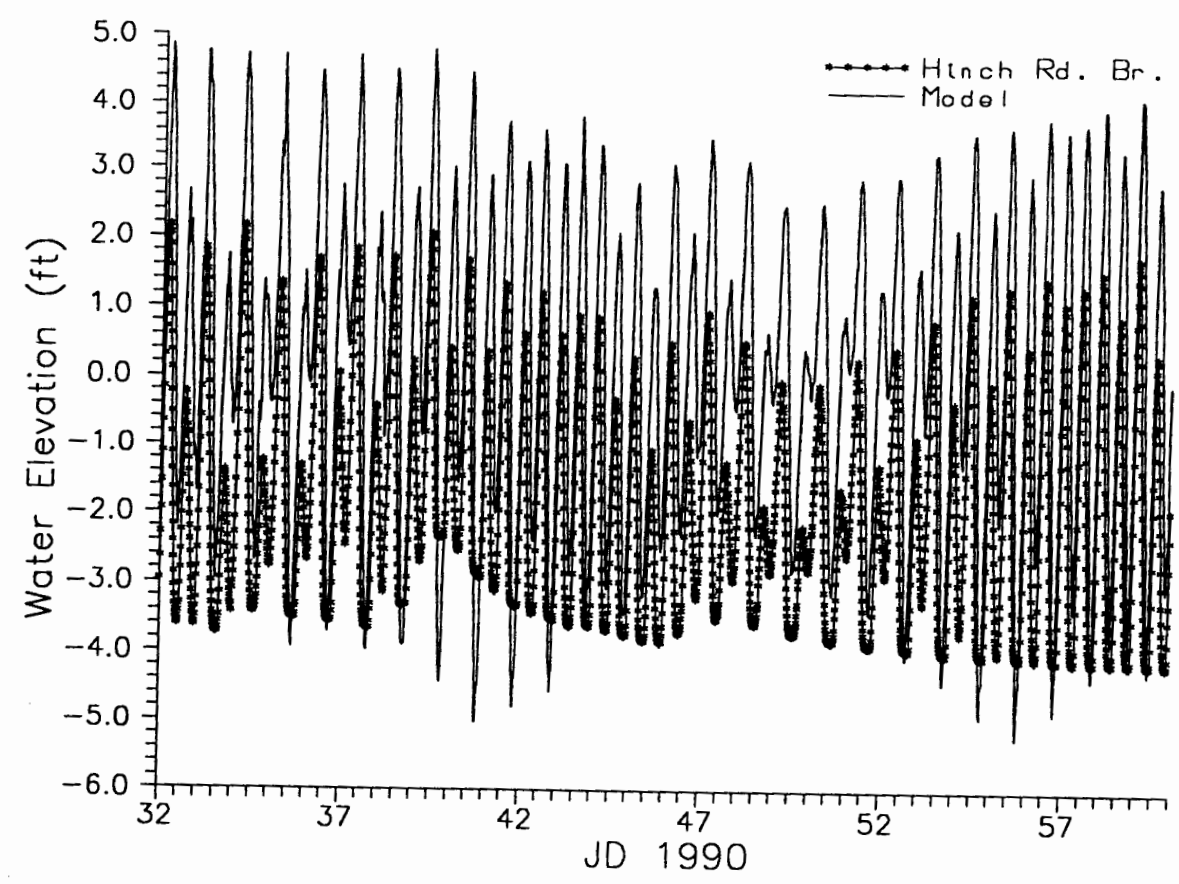

FIGURE 4.57 Model vs Hinch Rd. Br. Water Surface Elevations Final Calibration

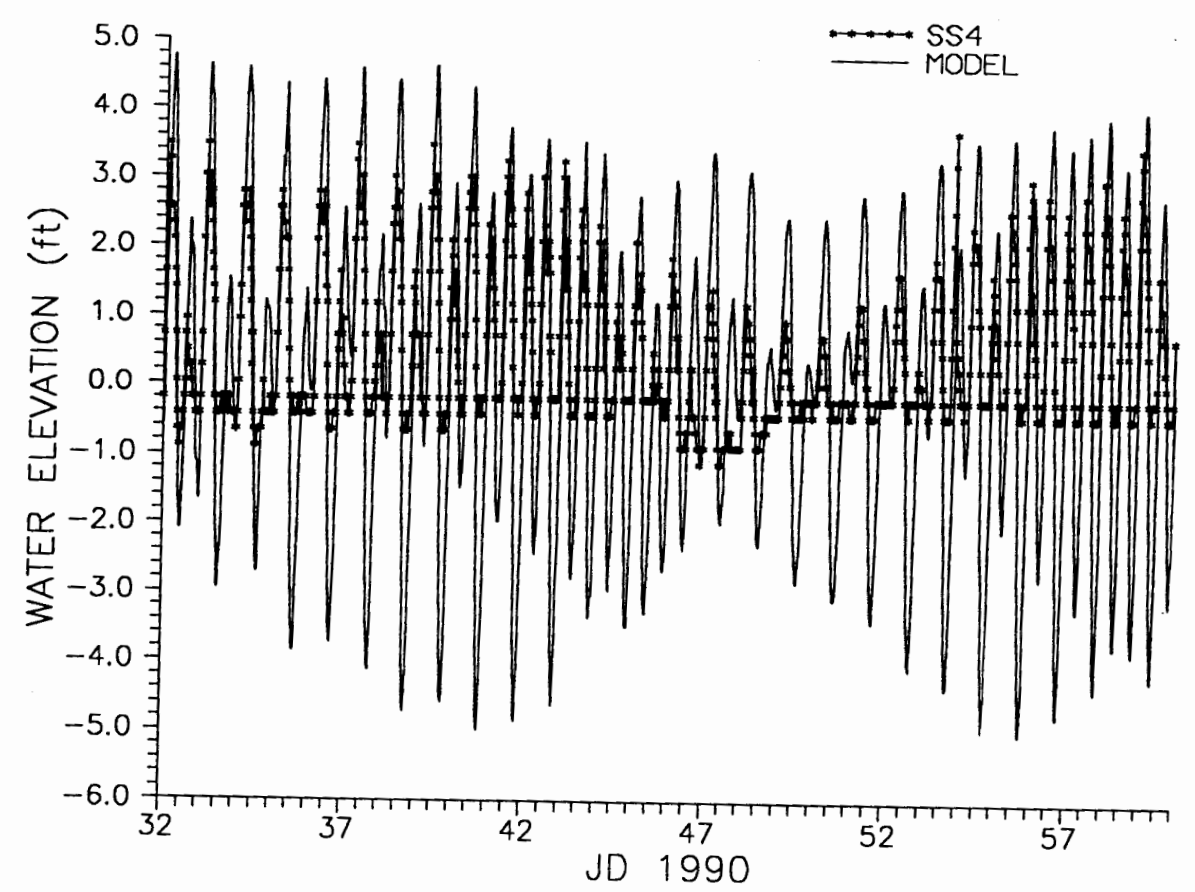

FIGURE 4.58 Model vs S4 Water Elevation

Final Calibration 


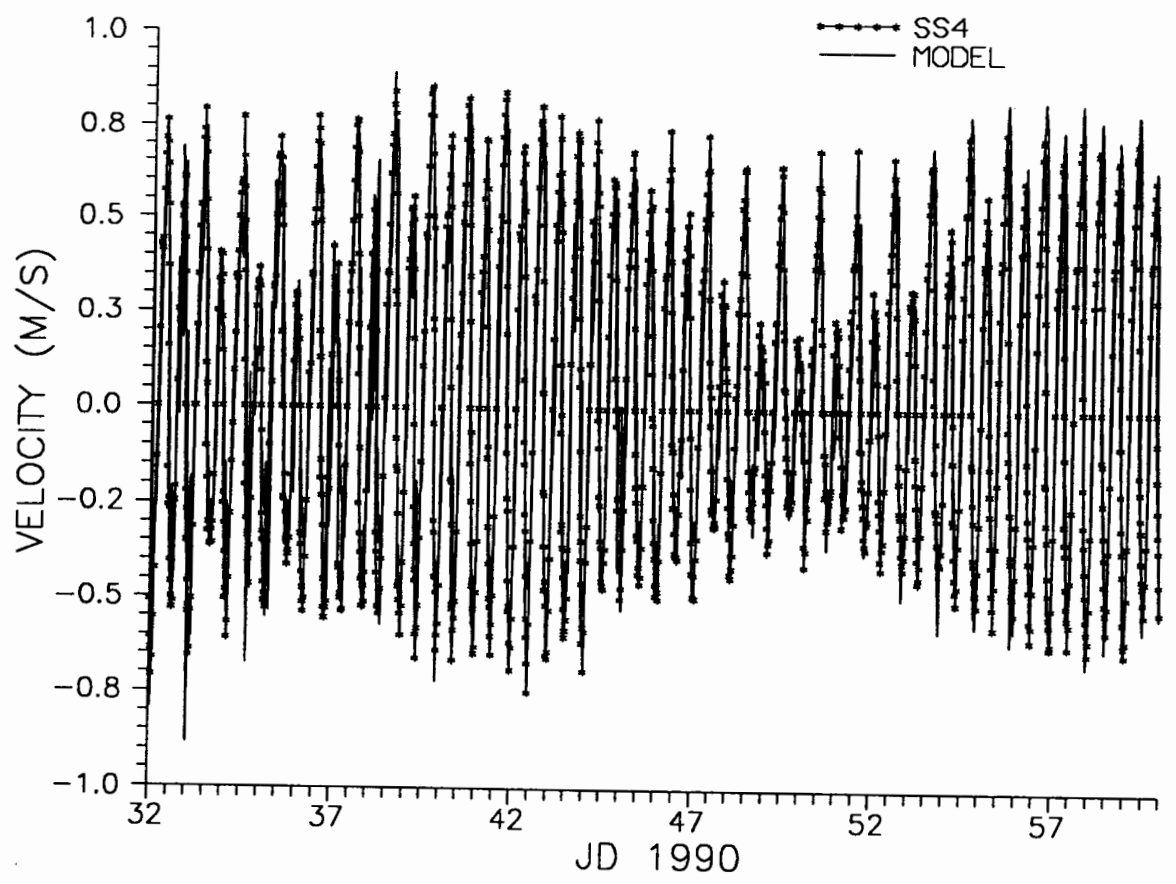

FIGURE 4.59 Model vs S4 Velocity Final Calibration

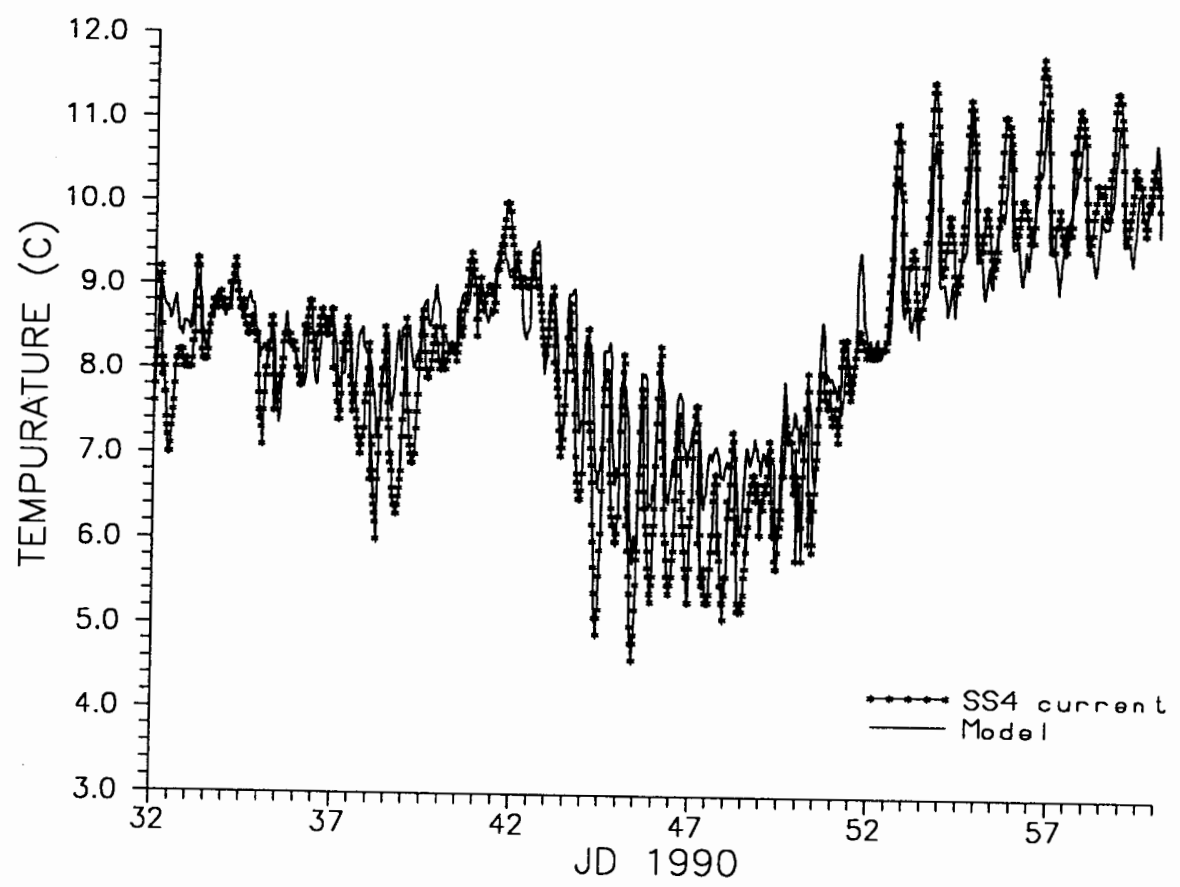

FIGURE 4.60 Model vs S4 Temperature

Final Calibration 


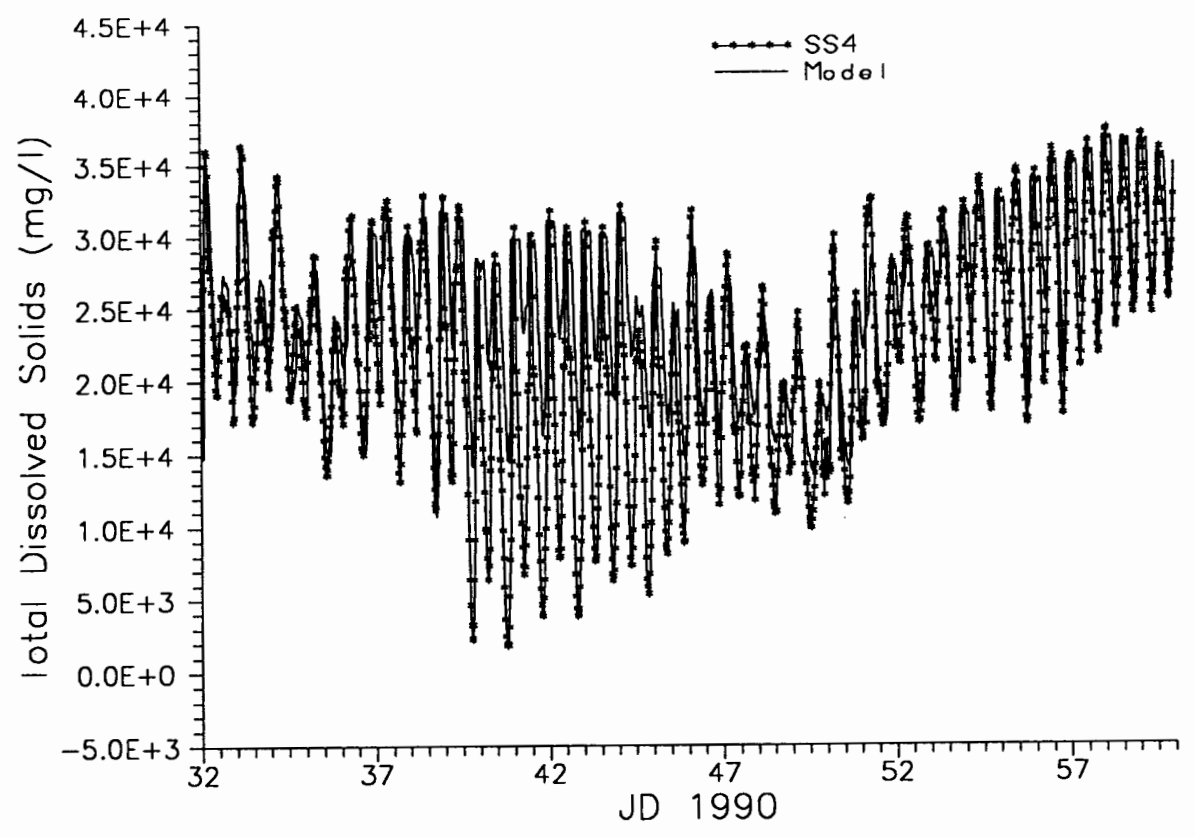

FIGURE 4.61 Model vs S4 Total Dissolved Solids Final Calibration 


\section{Management Analysis}

Four different scenarios were modeled for the management analysis. Two scenarios involved modeling the transport of a conservative tracer and two scenarios involved modeling bacteria transport. The tracer scenarios input a tracer concentration of equal mass at the two upstream arms. In one model run, tracer was input at the beginning of branch 2 and in the second model run, tracer was input at the beginning of branch 1 . The transport of tracer from Winchester Creek to Charleston Harbor was compared to the transport of tracer from Talbot and John B. Creeks to Charleston Harbor. The final two scenarios involved modeling of bacteria transport. The first bacteria transport scenario used an initial bacteria input everywhere in the South Slough. The final scenario used a constant bacteria input in all the inflows. No bacteria inflow from Charleston Harbor was assumed. All the management analysis used the calibration period, Julian Day 32 to 60 (February 1 to March 1), 1990.

For the first tracer scenario, a tracer concentration of $100 \mathrm{mg} / \mathrm{ml}$ was input into Winchester Creek inflow for the first day of the simulation, Julian Day 32 to 33. Flow in Winchester Creek for Julian Day 32 was $11.4 \mathrm{~m}^{3} / \mathrm{s}$. Modeled tracer concentrations for cells 13, 25, 37, 51, 61, 64, and 93 are shown in Figures 4.62 through 4.68 .

For the second tracer scenario, a tracer concentration of $180.0 \mathrm{mg} / \mathrm{ml}$ was input into the Talbot and John B. Creeks inflow for Julian Day 32 to 33. Flow in Talbot Creek and John B. Creek for Julian Day 32 was $6.3 \mathrm{~m}^{3} / \mathrm{s}$. The tracer concentration for both modeling scenarios was of equal mass, where mass = concentration $\mathrm{x}$ flow $\mathrm{x}$ time. Modeled tracer concentrations for cells 13, 25, 37, 51, 61, 64, and 93 are shown in Figures 4.69 through 4.75.

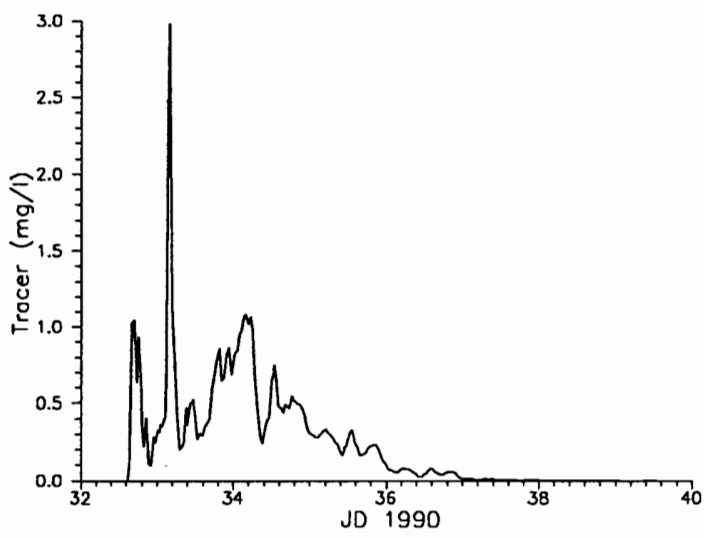

FIGURE 4.62 Modeled Tracer Winchester Creek, Cell 13

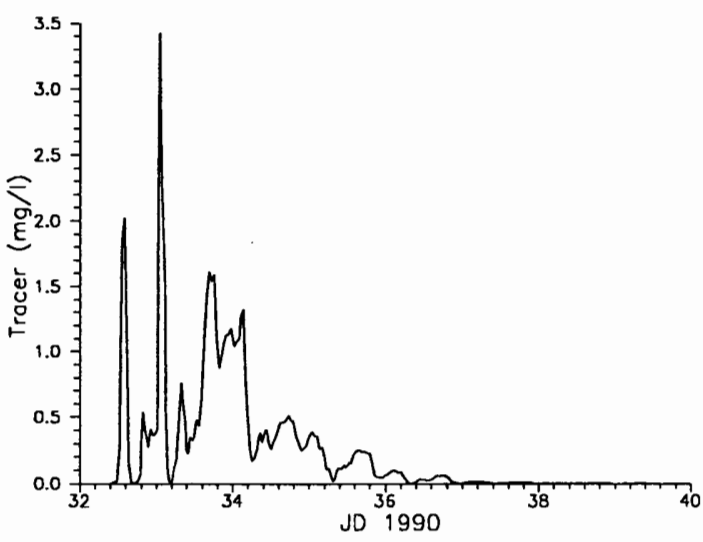

FIGURE 4.63 Modeled Tracer Winchester Creek, Cell 25 


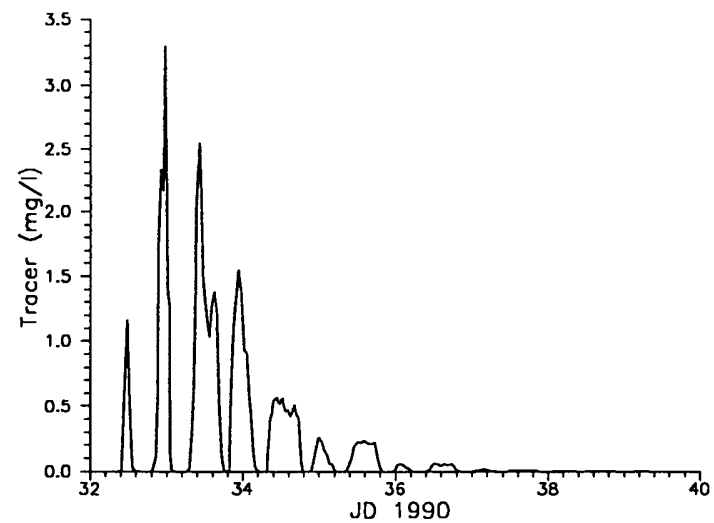

FIGURE 4.64 Modeled Tracer Winchester Creek, Cell 37

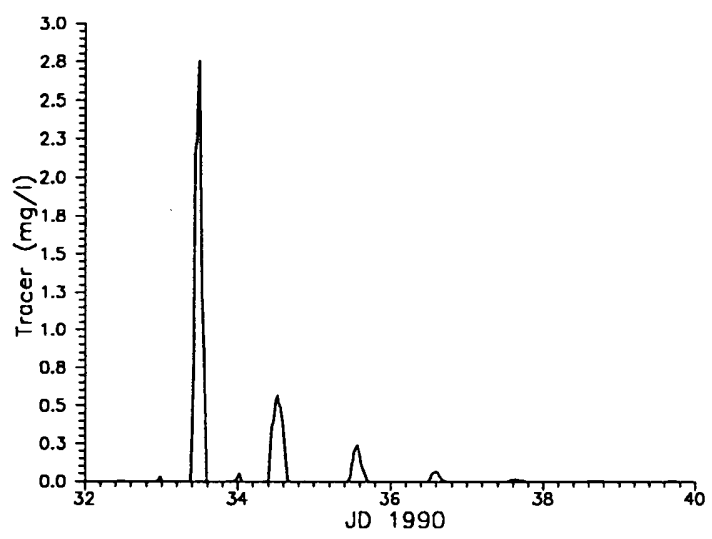

FIGURE 4.66 Modeled Tracer Winchester Creek, Cell 61

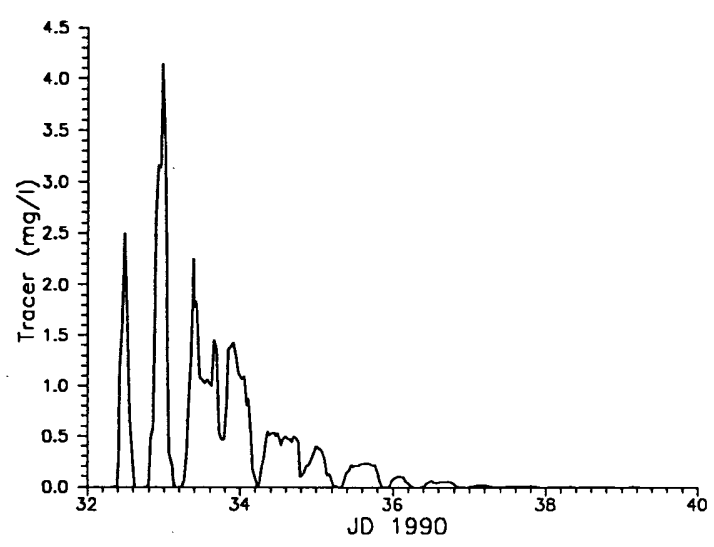

FIGURE 4.68 Modeled Tracer Winchester Creek, Cell 93

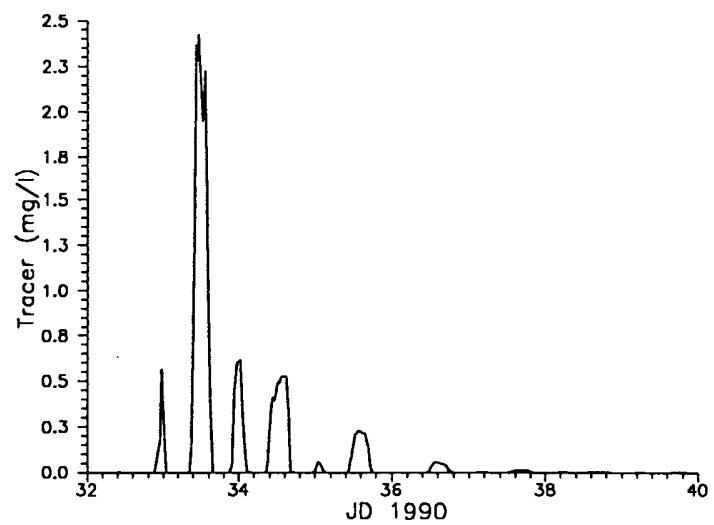

FIGURE 4.65 Modeled Tracer Winchester Creek, Cell 51

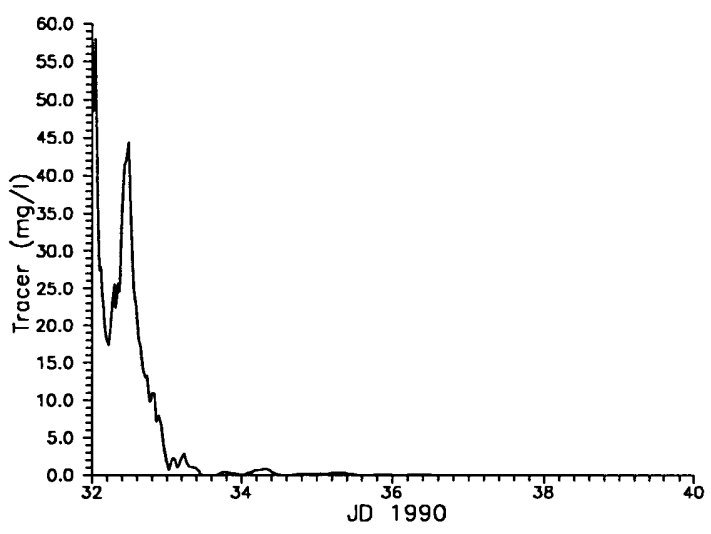

FIGURE 4.67 Modeled Tracer Winchester Creek, Cell 64 


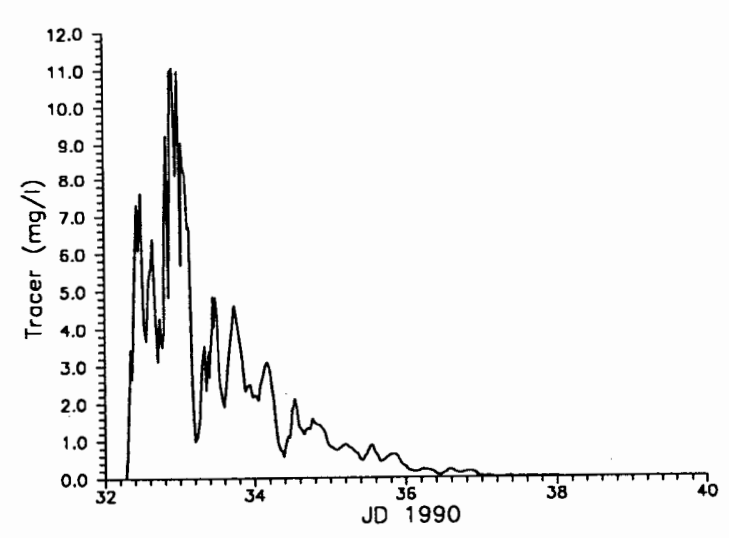

FIGURE 4.69 Modeled Tracer Talbot and John B. Creeks, Cell 13

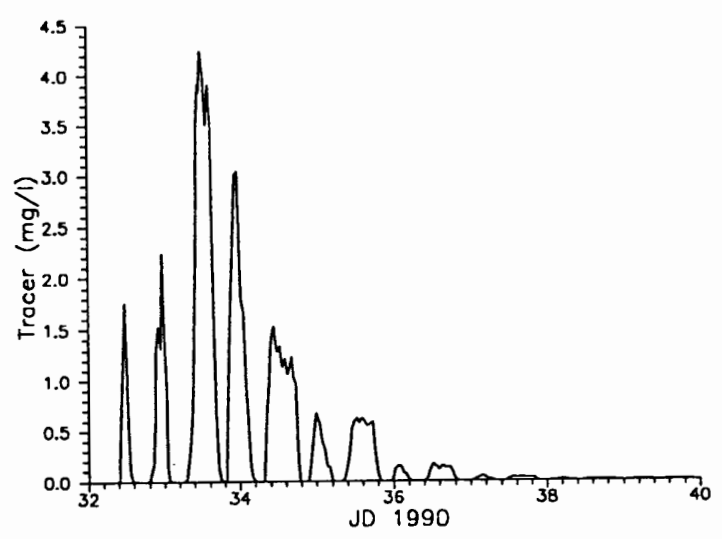

FIGURE 4.71 Modeled Tracer

Talbot and John B. Creeks, Cell 37

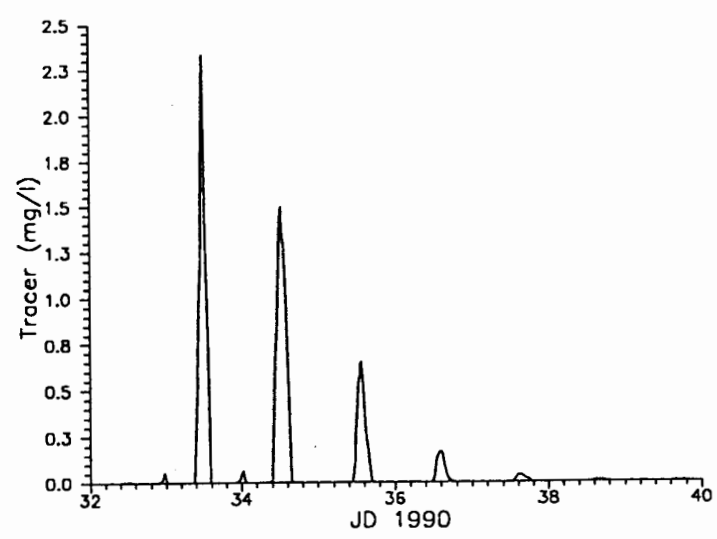

FIGURE 4.73 Modeled Tracer Talbot and John B. Creeks, Cell 61

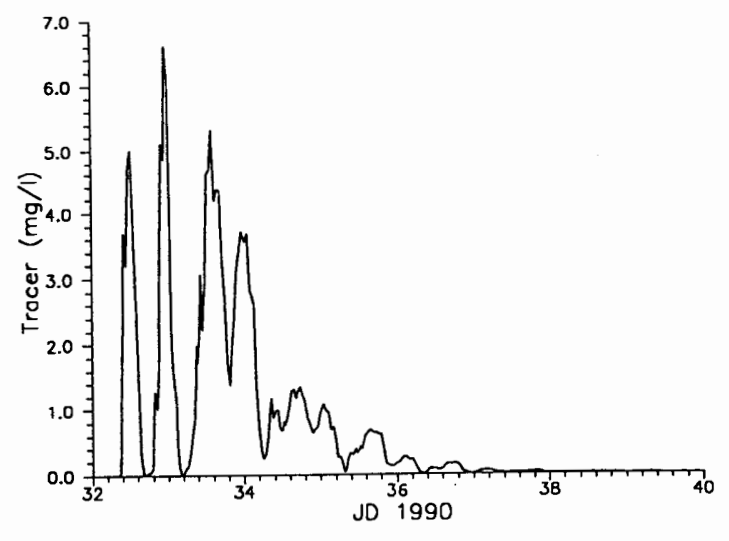

FIGURE 4.70 Modeled Tracer

Talbot and John B. Creeks, Cell 25

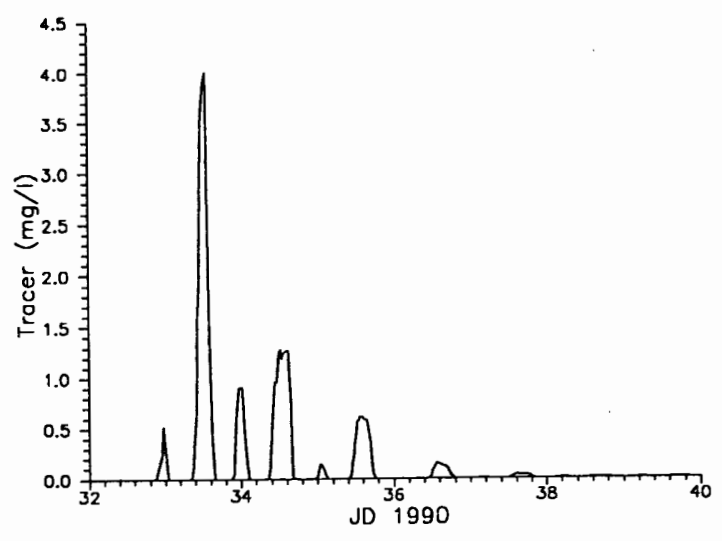

FIGURE 4.72 Modeled Tracer Talbot and John B. Creeks, Cell 51

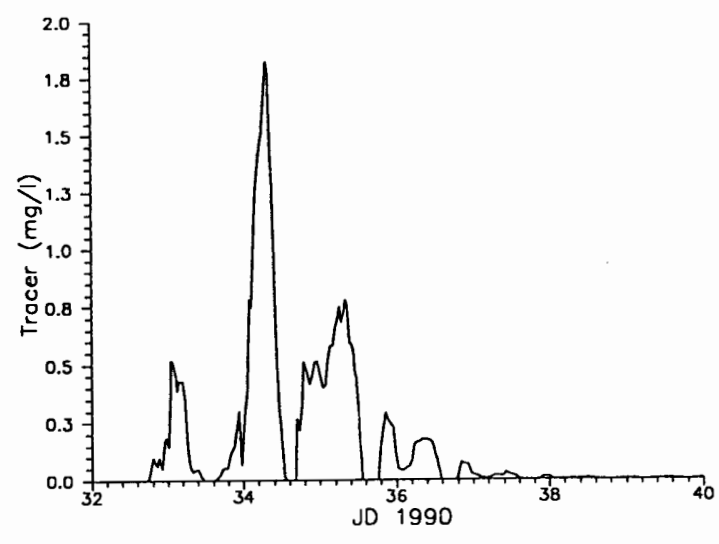

FIGURE 4.74 Modeled Tracer Talbot and John B. Creeks, Cell 64 


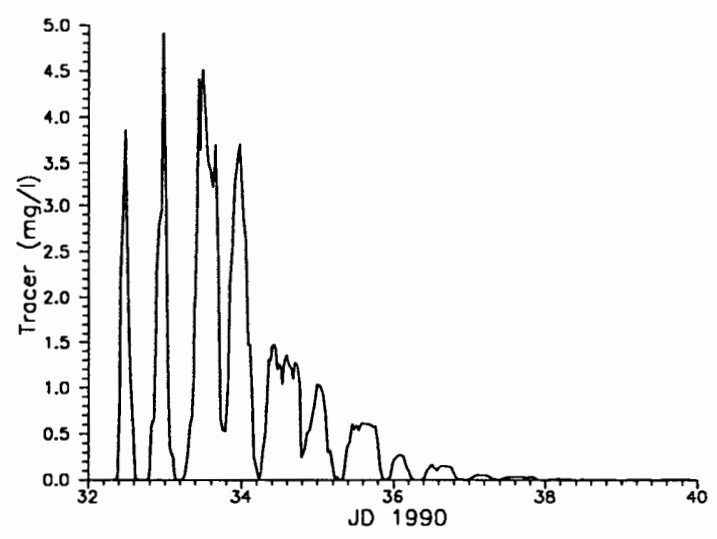

FIGURE 4.75 Modeled Tracer

Talbot and John B. Creeks, Cell 93

The tracer reaches Charleston Harbor on Julian Day 33.5 for both scenarios, but the peak concentration is slightly higher for the tracer originating from Winchester Creek. Tracer concentrations originating from Talbot and John B. creeks are carried upstream with the tide into the Winchester Creek arm. Tracer concentrations originating from Winchester Creek are carried upstream with the tide toward Talbot and John B. creeks.

The first bacteria transport scenario modeled had an initial bacteria input of 200 $\mathrm{col} / 100 \mathrm{ml}$, with no additional bacteria in the tributary inflows. Predicted bacteria concentrations for cells 13, 25, 37, 51, 61, 64, and 93 are shown in Figures 4.76 to 4.82 . This model condition was performed to determine the length of time bacteria would remain in the South Slough. The approximate length of time for bacteria removal was 3 days.

The final management analysis scenario modeled was an assumed constant bacteria concentration input of $1,000 \mathrm{col} / 100 \mathrm{ml}$ for all stream inflows. Modeled bacteria concentrations for cells 13, 25, 37, 51, 61, 64, and 93 are shown in Figures 4.83 to 4.89 . Peak bacteria concentrations occur during low water slack and the bacteria concentrations decrease during high water slack. Peak bacteria concentrations are the highest for cell 64, Winchester Creek near Hinch Road Bridge. Typical modeled bacteria concentrations for each vertical layer during the storm are shown in Figure 4.90. Statistical information, average, mean and standard deviation, of predicted coliform bacteria concentrations are shown in Table 4.4. For cell 64, the average bacteria concentration was $551.3 \mathrm{col} / 100 \mathrm{ml}$, median was $479.8 \mathrm{col} / 100 \mathrm{ml}$ and the standard deviation was 256.9 . For cell 61, Charleston Harbor, bacteria values were lower. The average bacteria concentration for cell 61 was $25.9 \mathrm{col} / 100 \mathrm{ml}$, the median $13.5 \mathrm{col} / 100 \mathrm{ml}$ and the standard deviation 36.6 . 


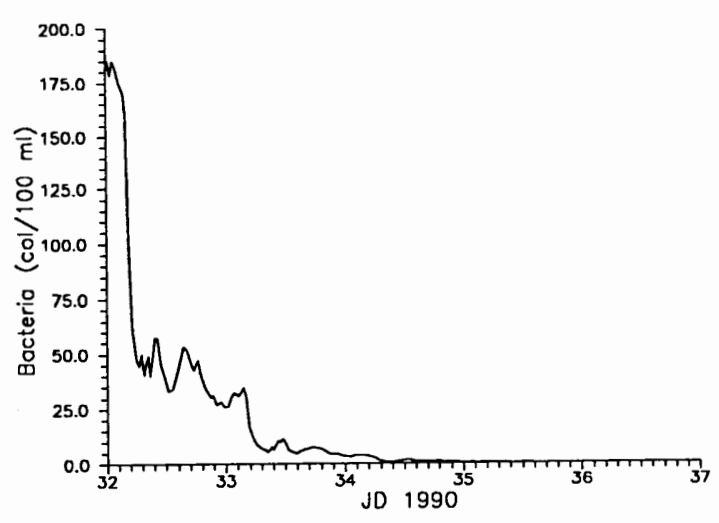

FIGURE 4.76 Modeled Bacteria Initial Input $200 \mathrm{col} / 100 \mathrm{ml}$, Cell 13

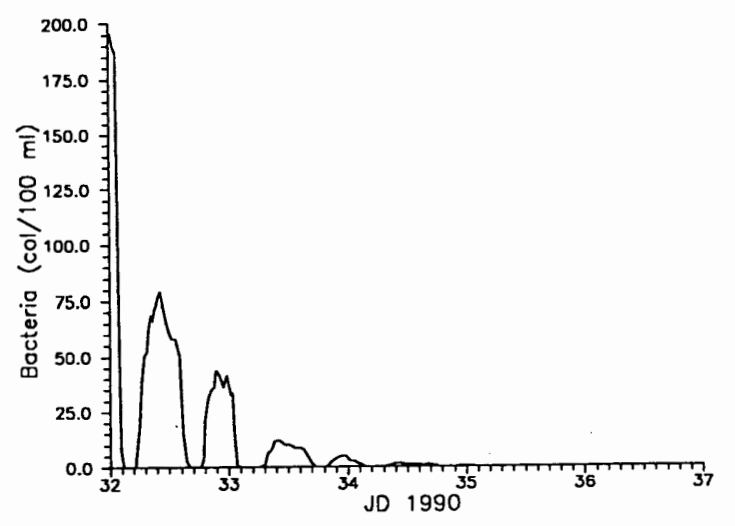

FIGURE 4.78 Modeled Bacteria Initial Input $200 \mathrm{col} / 100 \mathrm{ml}$, Cell 37

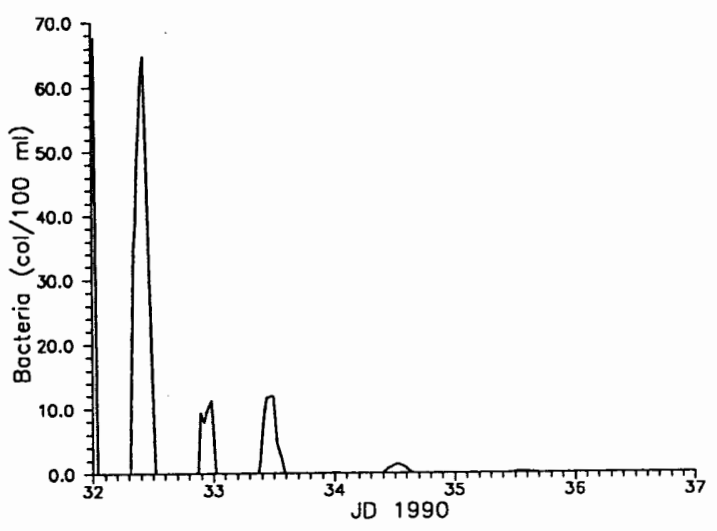

FIGURE 4.80 Modeled Bacteria Initial Input $200 \mathrm{col} / 100 \mathrm{ml}$, Cell 61

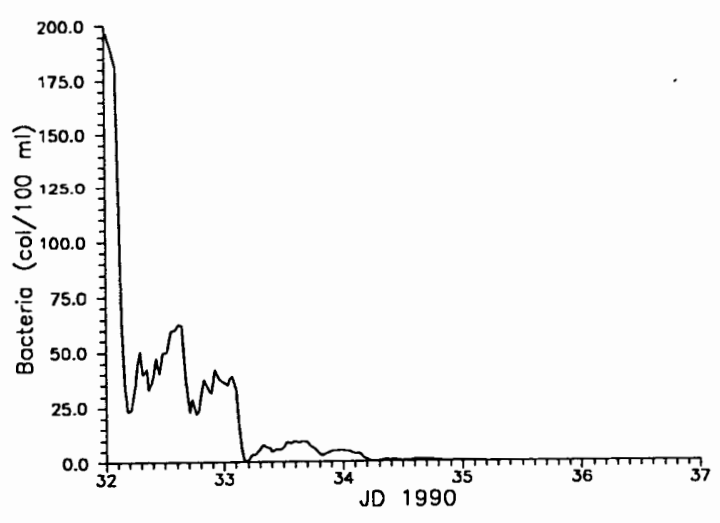

FIGURE 4.77 Modeled Bacteria Initial Input $200 \mathrm{col} / 100 \mathrm{ml}$, Cell 25

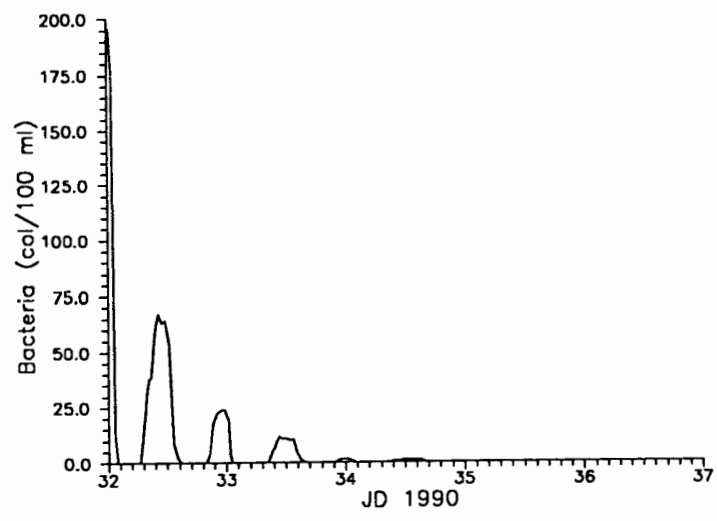

FIGURE 4.79 Modeled Bacteria Initial Input $200 \mathrm{col} / 100 \mathrm{ml}$, Cell 51

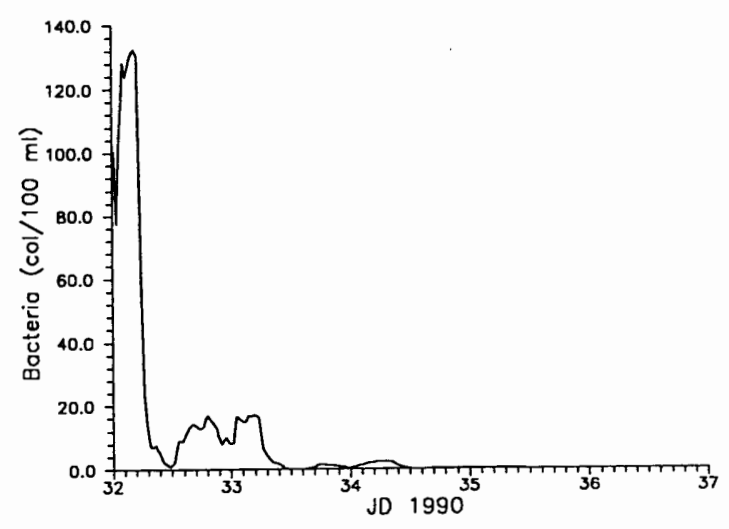

FIGURE 4.81 Modeled Bacteria Initial Input $200 \mathrm{col} / 100 \mathrm{ml}$, Cell 64 


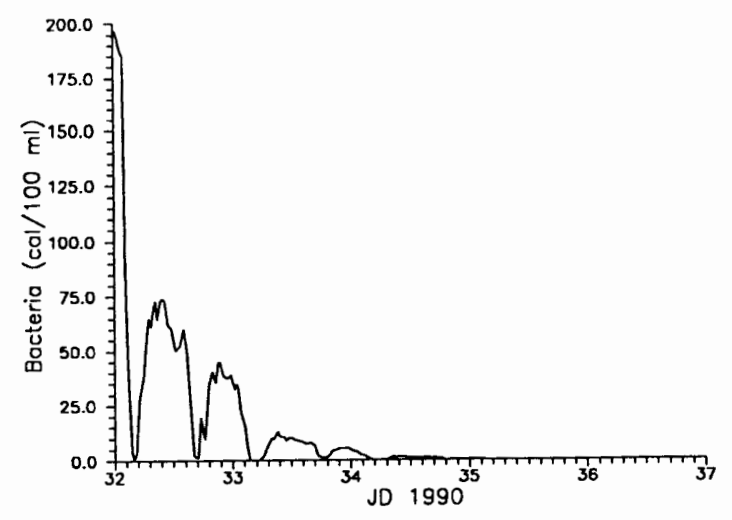

FIGURE 4.82 Modeled Bacteria Initial Input $200 \mathrm{col} / 100 \mathrm{ml}$, Cell 93

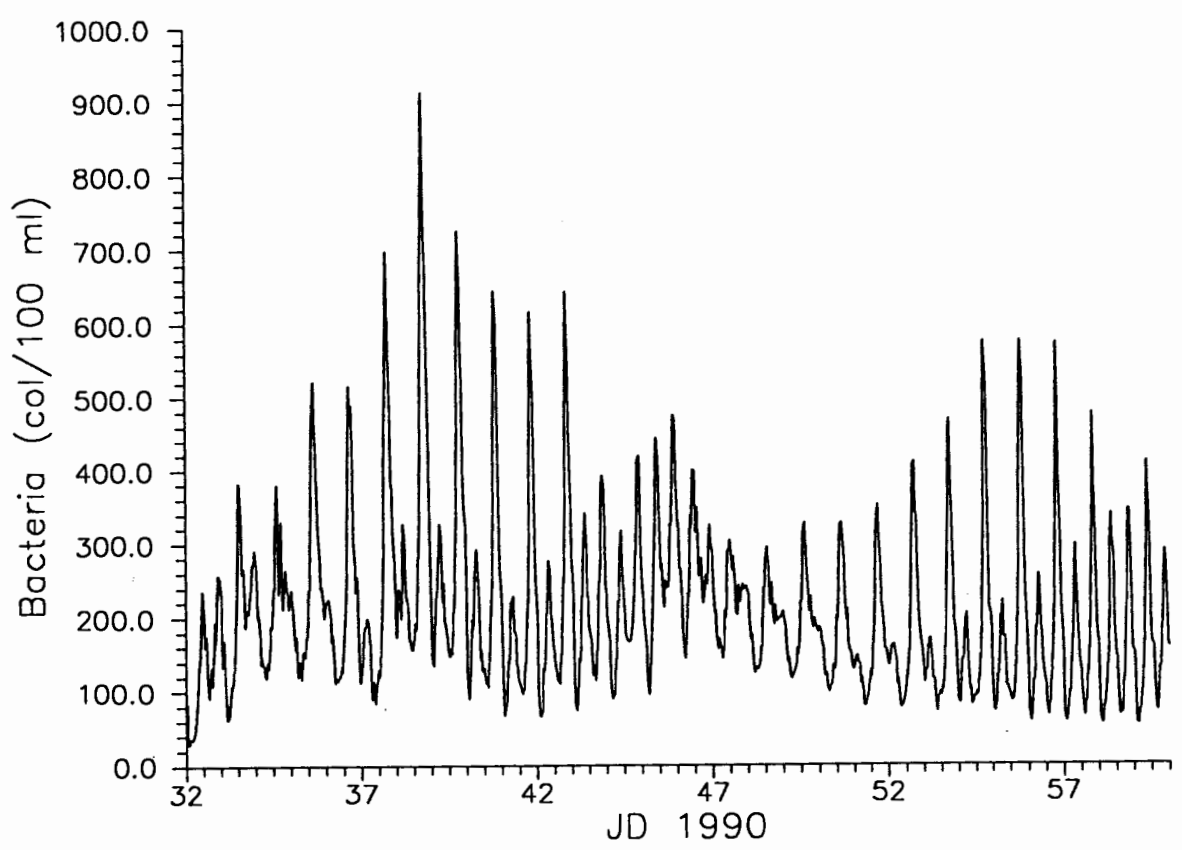

FIGURE 4.83 Modeled Bacteria Inflow Concentration 1,000 col/100 ml, Cell 13 


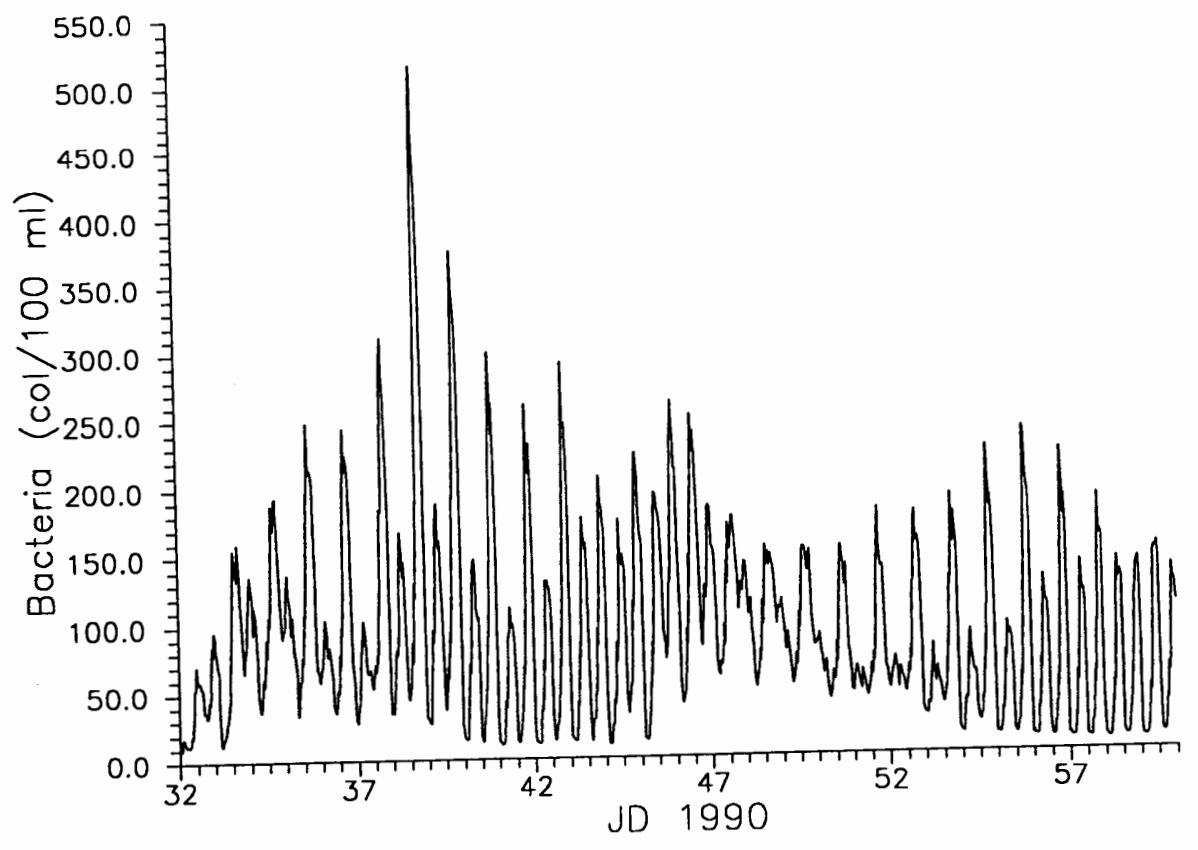

FIGURE 4.84 Modeled Bacteria Inflow Concentration 1,000 col/100 ml, Cell 25

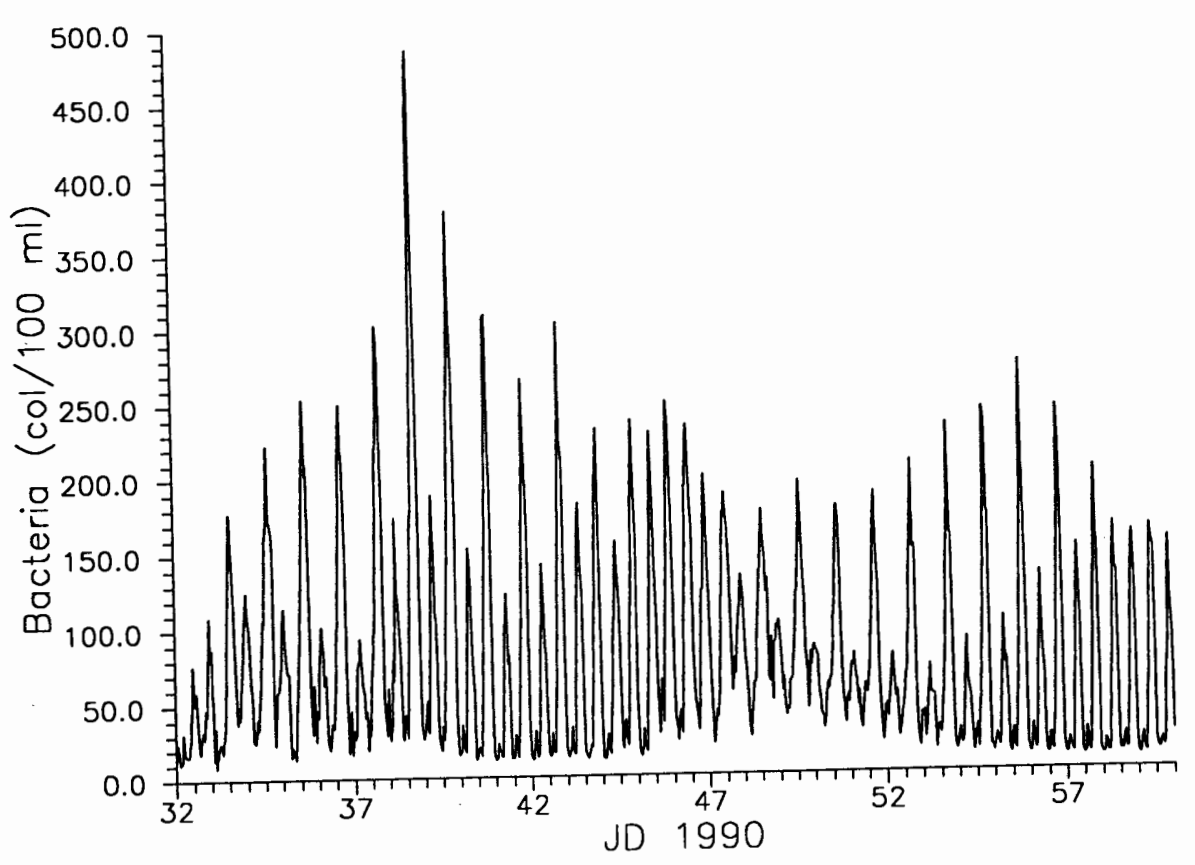

FIGURE 4.85 Modeled Bacteria Inflow Concentration 1,000 col/100 ml, Cell 37 


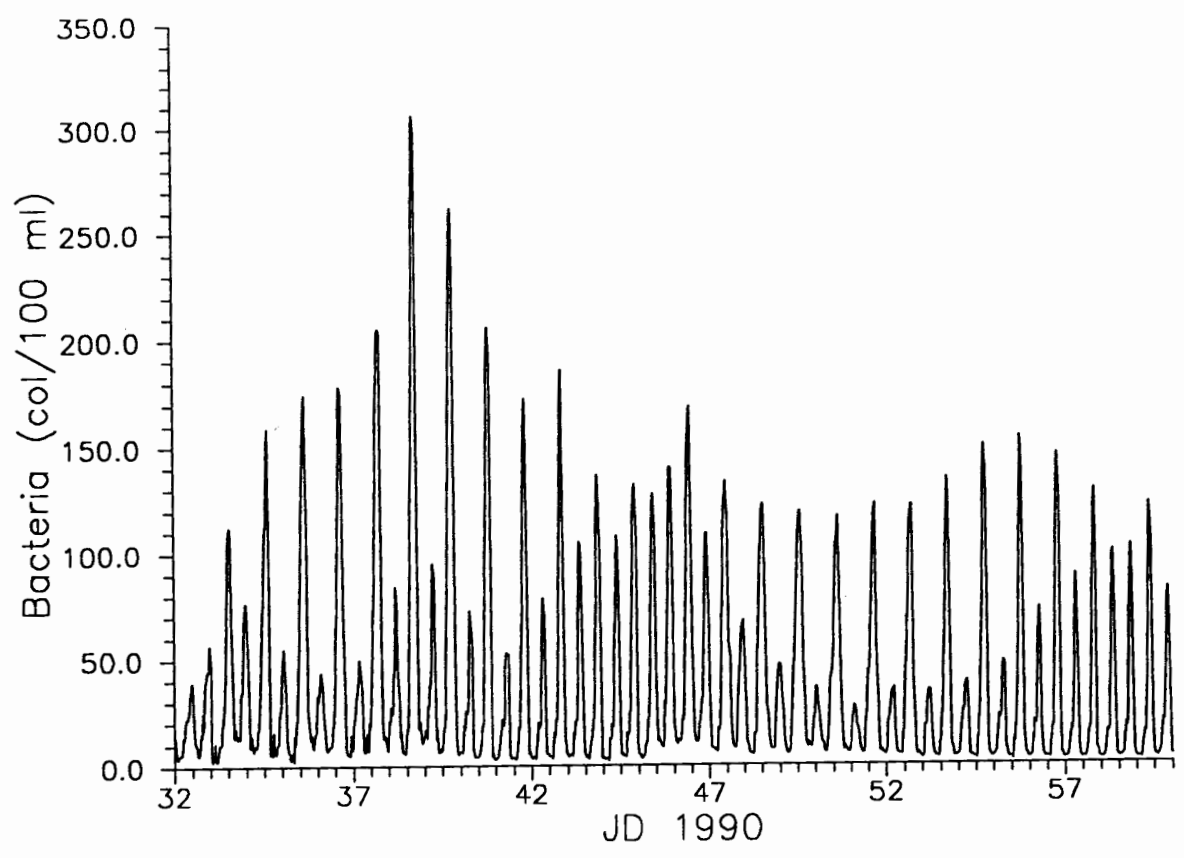

FIGURE 4.86 Modeled Bacteria

Inflow Concentration 1,000 col/100 ml, Cell 51

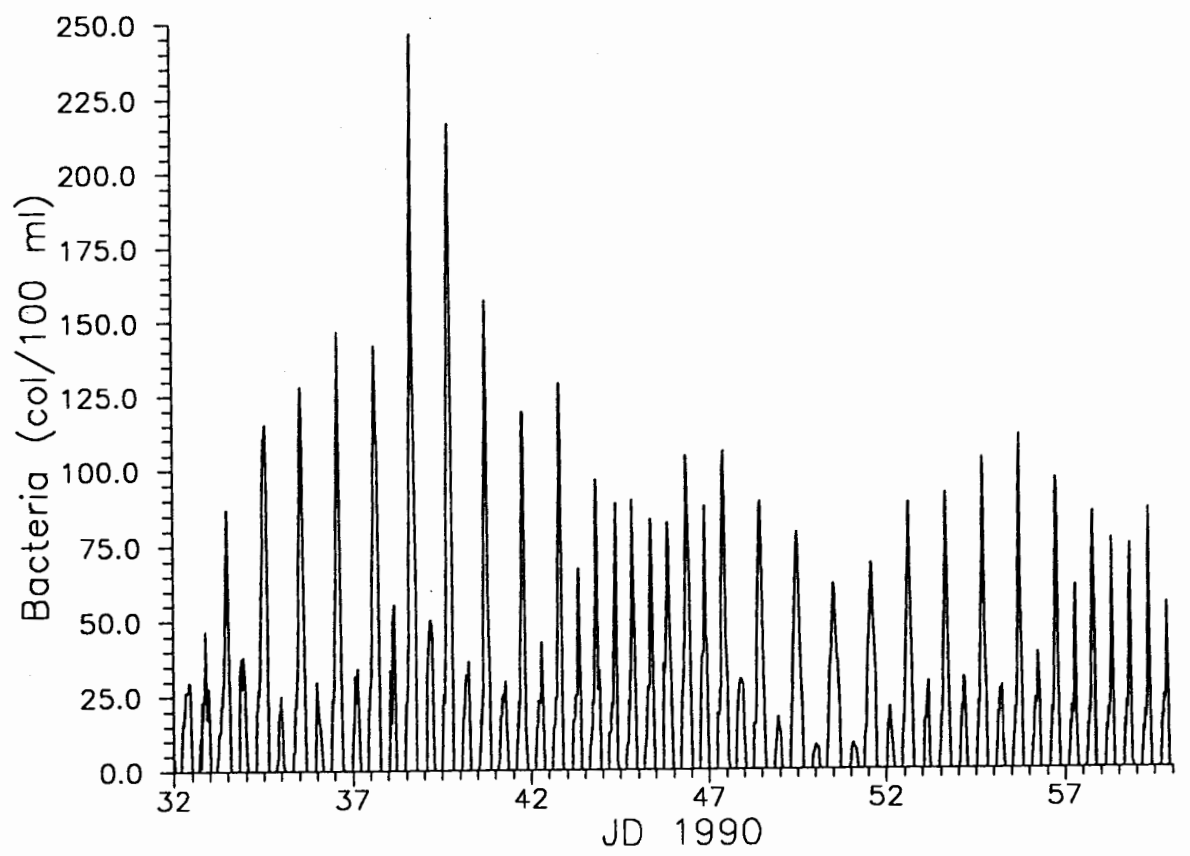

FTGURE 4.87 Modeled Bacteria

Inflow Concentration 1,000 col/100 ml, Cell 61 


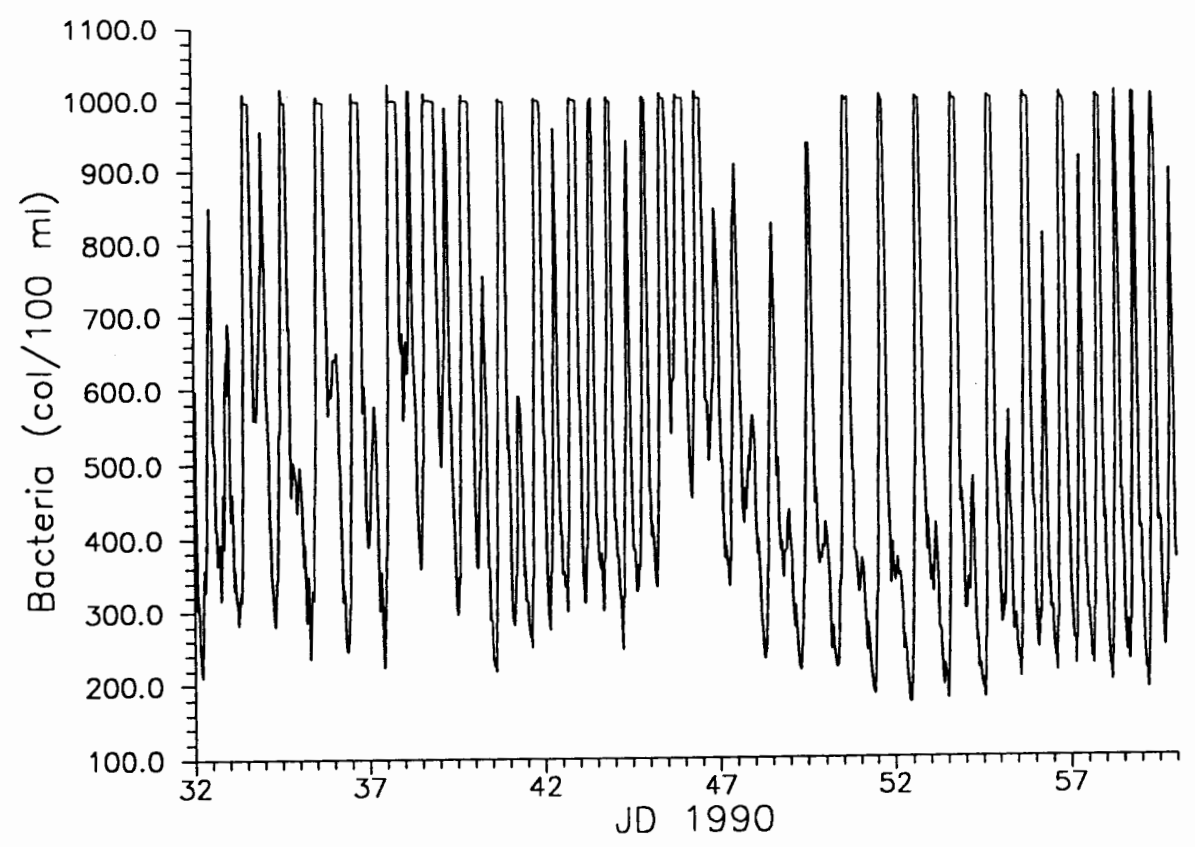

FIGURE 4.88 Modeled Bacteria

Inflow Concentration 1,000 col/100 ml, Cell 64

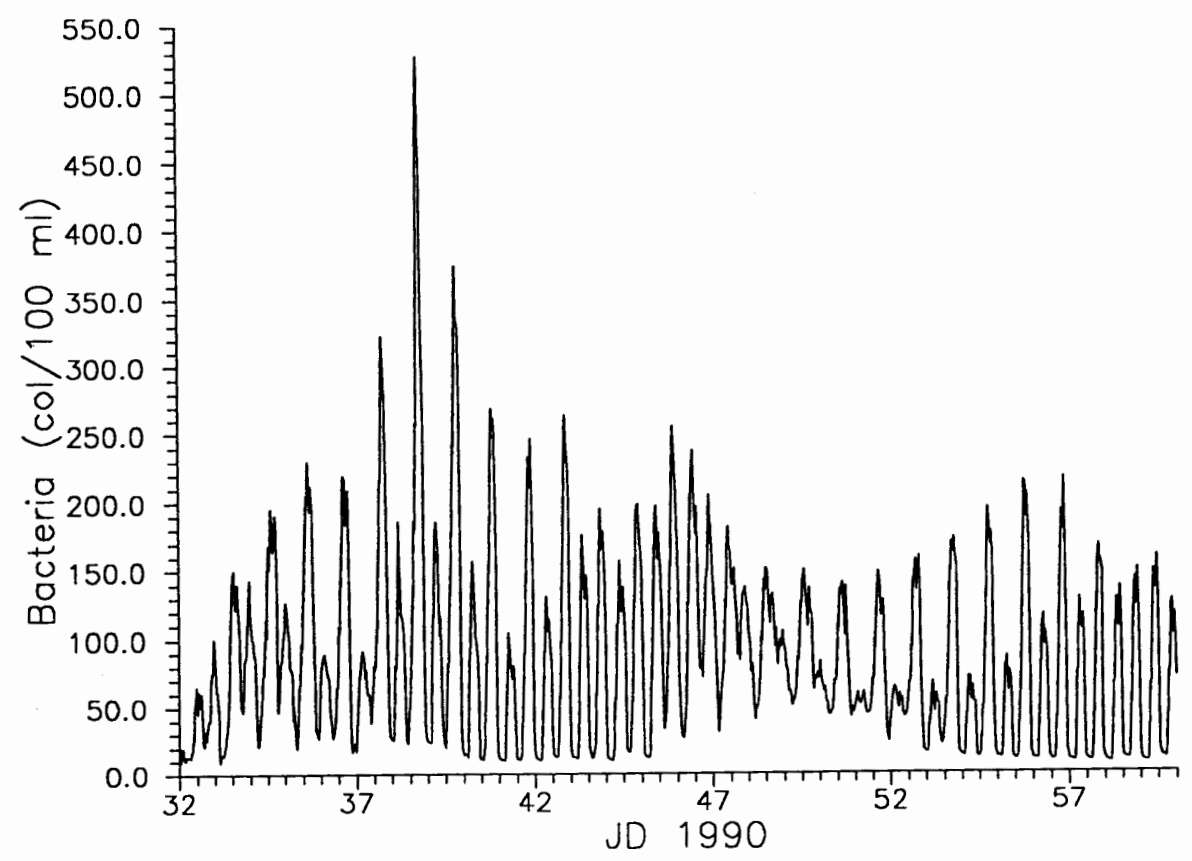

FIGURE 4.89 Modeled Bacteria

Inflow Concentration 1,000 col/100 ml, Cell 93 


\begin{tabular}{|c|c|c|c|c|}
\hline Cell\# & Description & Average & Median & $\begin{array}{l}\text { Standard } \\
\text { Deviation }\end{array}$ \\
\hline 13 & Elliot Creek enters South Slough & 211.51 & 184.55 & 121.23 \\
\hline 25 & South Slough upstream of Winchester Creek arm & 92.07 & 75.32 & 68.56 \\
\hline 37 & Day Creek enters South Slough & 82.86 & 62.59 & 69.78 \\
\hline 51 & South Slough, between Hayward Creek and Joe Ney Slough & 44.01 & 22.01 & 50.38 \\
\hline 61 & Charleston Harbor & 25.88 & 13.54 & 36.60 \\
\hline 64 & Hinch Road Bridge, Winchester Creek arm & 551.29 & 479.80 & 256.93 \\
\hline 93 & Branch 1 and branch 2 Junction & 90.99 & 77.76 & 70.43 \\
\hline
\end{tabular}

TABLE 4.4 Modeled Bacteria Concentration Statistics for Inflow Concentrations of 1,000 col/100 ml 
$\begin{array}{lll}\text { February } 5, \quad 1990 \text { Julian } \quad \text { Date } & 35 \text { days } \quad 7.21 \text { hours }\end{array}$

Tide In

Coliform $\mathrm{g} / \mathrm{m}^{\wedge} 3$

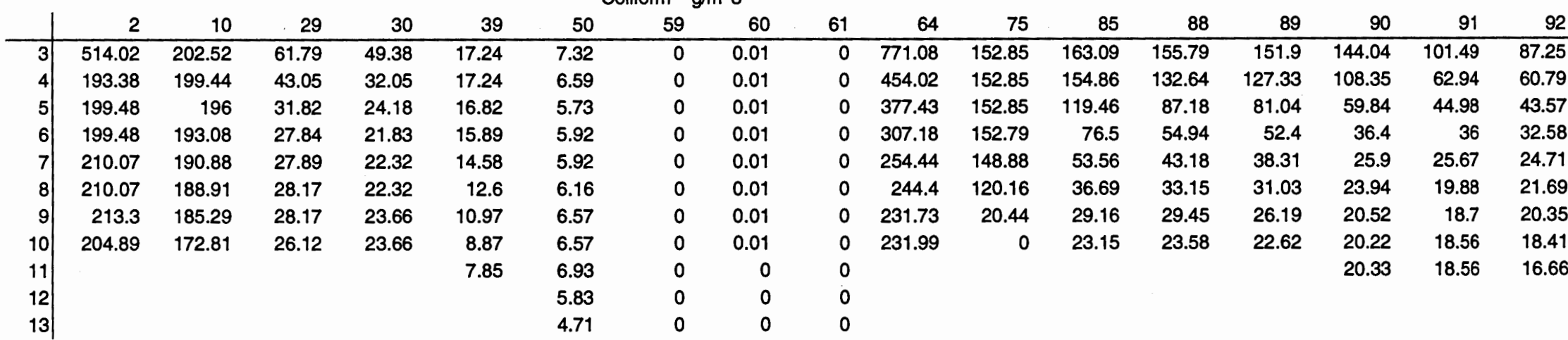

February 5, 1990 Julian Date $\quad 35$ days $\quad 14.41$ hours

Tide Out

\begin{tabular}{|c|c|c|c|c|c|c|c|c|c|c|c|c|c|c|c|c|c|}
\hline & 2 & 10 & 29 & 30 & 39 & 50 & 59 & 60 & 61 & 64 & 75 & 85 & 88 & 89 & 90 & 91 & 92 \\
\hline 6 & 1012.7 & 693.71 & 279.84 & 283.12 & 254.52 & 135.81 & 164.74 & 162.28 & 158.65 & 997.96 & 929.05 & 489.95 & 387.16 & 359.5 & 331 & 311.19 & 306.45 \\
\hline 7 & 1012.7 & 607.89 & 246.22 & 246.67 & 239.08 & 184.18 & 163.33 & 161.7 & 148.6 & 998 & 782.47 & 387.82 & 330.75 & 311.4 & 291.16 & 271.13 & 267.96 \\
\hline 8 & 1026.06 & 486.75 & 208.01 & 210.05 & 204.6 & 176.42 & 158.52 & 155.97 & 125.69 & 998 & 404.67 & 274.75 & 237.84 & 218.4 & 196.35 & 178.28 & 178.26 \\
\hline 9 & 1026.06 & 392.69 & 170.88 & 184.15 & 174.66 & 161.24 & 148.64 & 147.36 & 99.06 & 998 & 137.42 & 101.59 & 93.91 & 105.8 & 145.55 & 147.63 & 132.58 \\
\hline 10 & 1036.92 & 266.24 & 89.52 & 116.21 & 164.89 & 151.2 & 137.63 & 139.34 & 67.1 & 997.97 & 36.98 & 19.63 & 40.74 & 36.09 & 77.44 & 83.48 & 57.56 \\
\hline 11 & & & & & 160.47 & 144.76 & 128.59 & 129.3 & 24.01 & & & & & & 53.28 & 48.52 & 29.93 \\
\hline 12 & & & & & & 142.39 & 121.53 & 107.81 & 0 & & & & & & & & \\
\hline 13 & & & & & & 139.07 & 118.22 & 64.03 & 0 & & & & & & & & \\
\hline
\end{tabular}

FIGURE 4.90 Bacteria Concentrations for Vertical Layers

Tide in (Top) and Tide out (bottom) 
This Oregon Health Division's Sanitation Management Plan for Commercial Shellfish Harvesting in Joe Ney and South Slough, in Appendix A, shows that when the rainfall is over 1.5 inches in one day or 5 inches over 5 days, shellfishing in the slough would be closed. In order to evaluate this strategy, Table 4.5 lists the in/day recorded at the North Bend Airport, days where the rainfall is over 1.5 inches, total rainfall for every 5 day period and the days that the 5 day period is equal or over 5 inches. The final column in Table 4.5 indicates when the Joe Ney and South Slough were closed for shellfish harvesting according to the management plan policy of at least 5 days following either a 5-day rainfall total of 5 inches or a one day total of 1.5 inches. There were 18 days, Julian Days 292 to 296, 304 to 311, and 318 to 322, when the Joe Ney and South Slough would have been closed for shellfish harvesting. None of these occurrences were during the calibration period of Julian Day 32 to 60 .

The Oregon Administrative Rules, Chapter 340, Division 41 (p. 17) states that the standards for marine waters and estuarine shellfish growing waters are a median concentration of fecal coliform of 14 organisms $/ 100 \mathrm{ml}$, with not more than 10 percent of the samples exceeding 43 organisms/100 ml. Cell 61 was the only cell that had a median less than 14 organisms $/ 100 \mathrm{ml}$ during the calibration storm, assuming an inflow of $1000 \mathrm{col} / 100 \mathrm{ml}$ (see Table 4.4). Histograms for the calibration storm for cells 13, 25, 37, 51, 61, 64, and 93 are shown in Figures 4.91 to 4.97. None of the cells had less than 10 percent exceeding 43 organisms $/ 100 \mathrm{ml}$. Charleston Harbor, cell 61, was the closest to meeting the standard with a median of 13.54 and $21 \%$ exceeding 43 organisms $/ 100 \mathrm{ml}$. The Winchester Creek, cell 64 , had the highest concentrations of bacteria with a median of 479.8 and 100 percent exceeding 43 organisms $/ 100 \mathrm{ml}$.

To determine the effectiveness of the management plan policy for closure of shellfish harvesting in Joe Ney and South Sloughs, bacteria concentration of the inflow tributaries during a storm event would need to be sampled. This management analysis however, could be used to develop a bacteria sampling plan for the South Slough. To obtain representative bacteria data for the South Slough, samples should be taken at low and high tide, different depths and a variety of locations along the South Slough. 


\begin{tabular}{|c|c|c|c|c|c|}
\hline JD & IN/DAY & $\begin{array}{l}>1.5 \text { inches } \\
\text { in one day }\end{array}$ & $\begin{array}{l}\text { Previous } 5 \text { Day } \\
\text { Rain Total (in) }\end{array}$ & $\begin{array}{l}>=5 \text { inches } \\
\text { in a } 5 \text { days }\end{array}$ & $\begin{array}{l}\text { Sheilfishing } \\
\text { Closure }\end{array}$ \\
\hline 289 & 0.07 & & 0.8 & & \\
\hline 290 & 0.03 & & 0.56 & & \\
\hline 291 & 2.96 & $x$ & 3.47 & & \\
\hline 292 & 0 & & 3.31 & & $x$ \\
\hline 293 & 0 & & 3.06 & & $x$ \\
\hline 294 & 1.33 & & 4.32 & & $x$ \\
\hline 295 & 0.03 & & 4.32 & & $x$ \\
\hline 296 & 0 & & 1.36 & & $x$ \\
\hline 297 & 0 & & 1.36 & & \\
\hline 298 & 1.16 & & 2.52 & & \\
\hline 300 & 0.84 & & 2.03 & & \\
\hline 301 & 0 & & 2 & & \\
\hline 302 & 0.86 & & 2.86 & & \\
\hline 303 & 3.63 & $x$ & 6.49 & $x$ & \\
\hline 304 & 0.46 & & 5.79 & $x$ & $x$ \\
\hline 305 & 0.14 & & 5.09 & $x$ & $x$ \\
\hline 306 & 0.01 & & 5.1 & $x$ & $x$ \\
\hline 307 & 0.17 & & 4.41 & & $x$ \\
\hline 308 & 1.1 & & 1.88 & & $x$ \\
\hline 309 & 0.3 & & 1.72 & & $x$ \\
\hline 310 & 0.02 & & 1.6 & & $x$ \\
\hline 311 & 0.26 & & 1.85 & & $x$ \\
\hline 312 & 0.23 & & 1.91 & & \\
\hline 313 & 0 & & 0.81 & & \\
\hline 314 & 0 & & 0.51 & & \\
\hline 315 & 0 & & 0.49 & & \\
\hline 316 & 0.1 & & 0.33 & & \\
\hline 317 & 2.28 & $x$ & 2.38 & & \\
\hline 318 & 0.03 & & 2.41 & & $x$ \\
\hline 319 & o & & 2.41 & & $x$ \\
\hline 320 & 0 & & 2.41 & & $x$ \\
\hline 321 & 0.83 & & 3.14 & & $x$ \\
\hline 322 & 0 & & 0.86 & & $x$ \\
\hline 323 & 0.95 & & 1.78 & & \\
\hline 324 & 0.69 & & 2.47 & & \\
\hline
\end{tabular}

Table 4.5 Shellfish Harvest Closure for 1990 


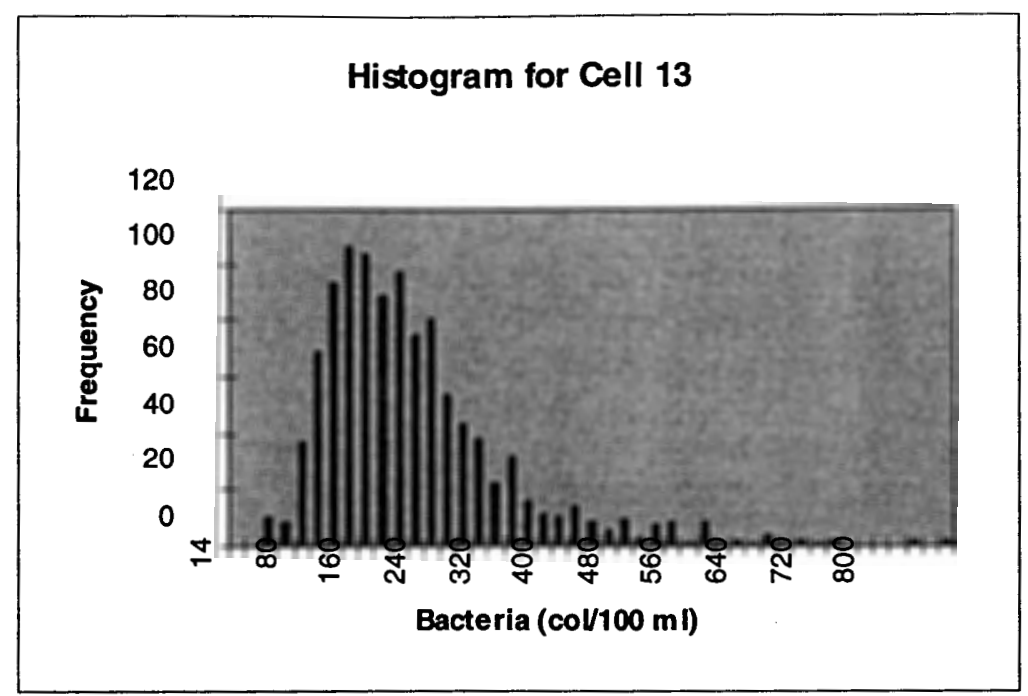

FIGURE 4.91

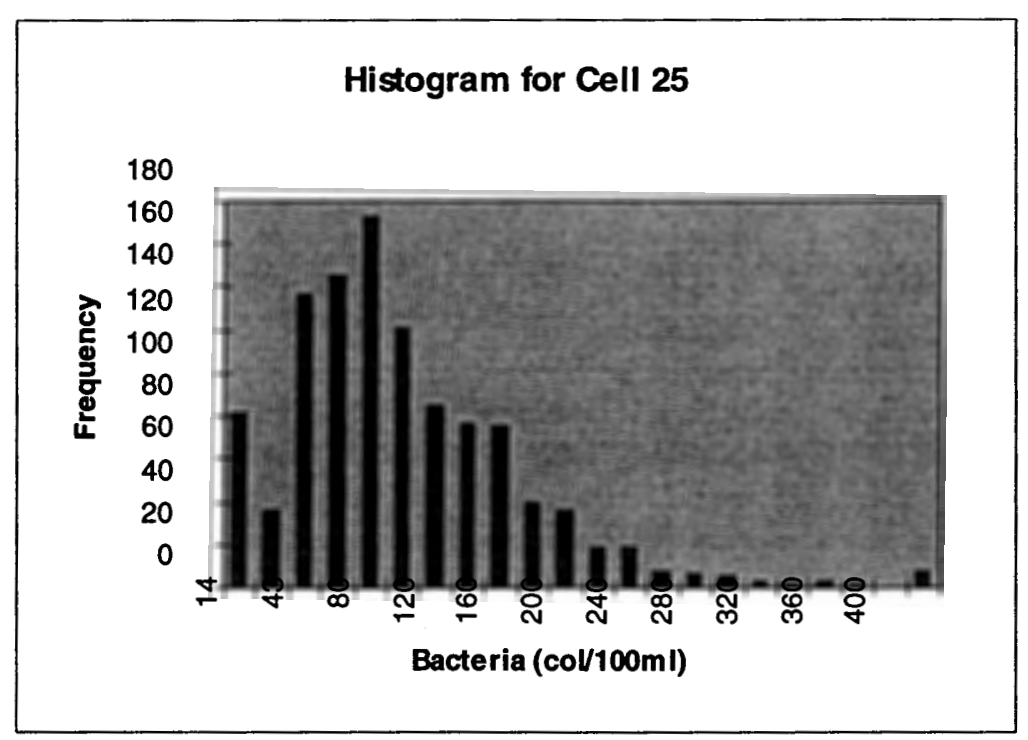

FIGURE 4.92 


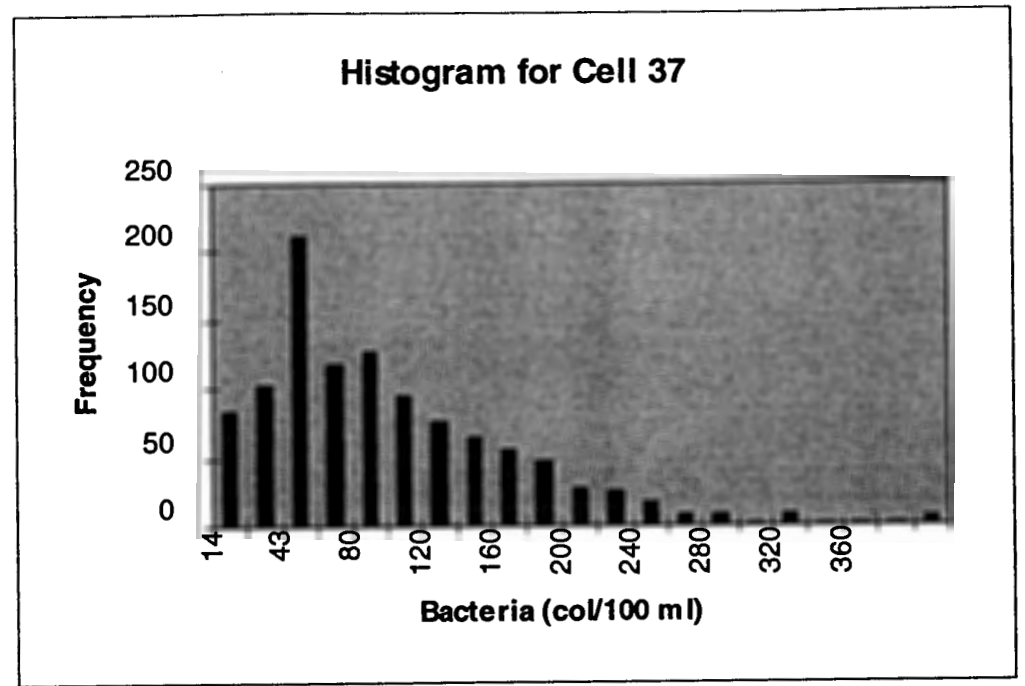

FIGURE 4.93

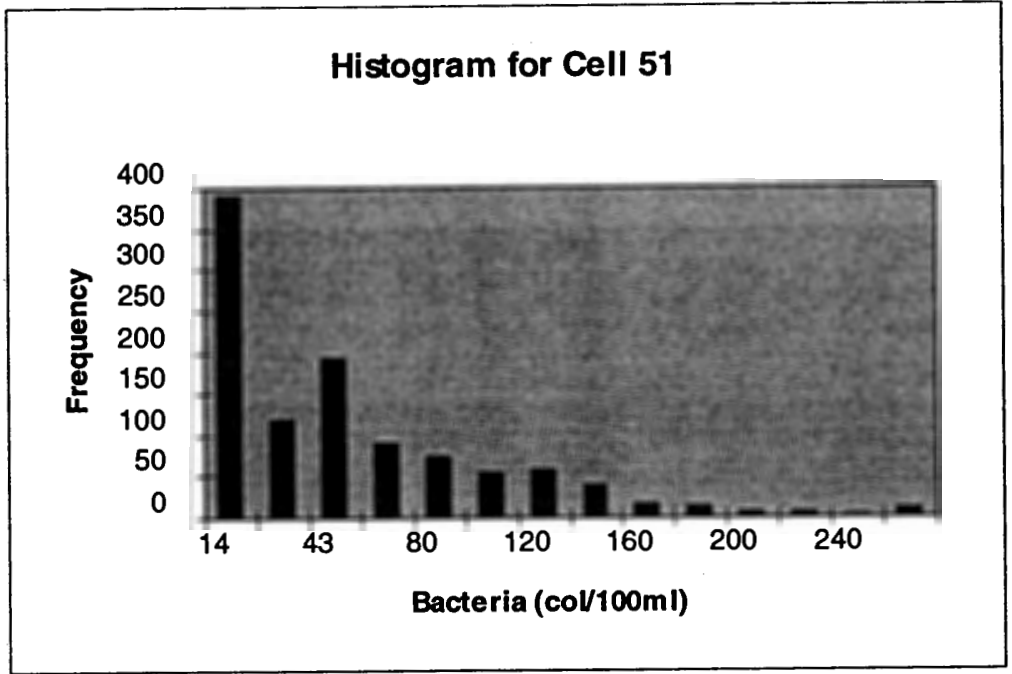

FIGURE 4.94 


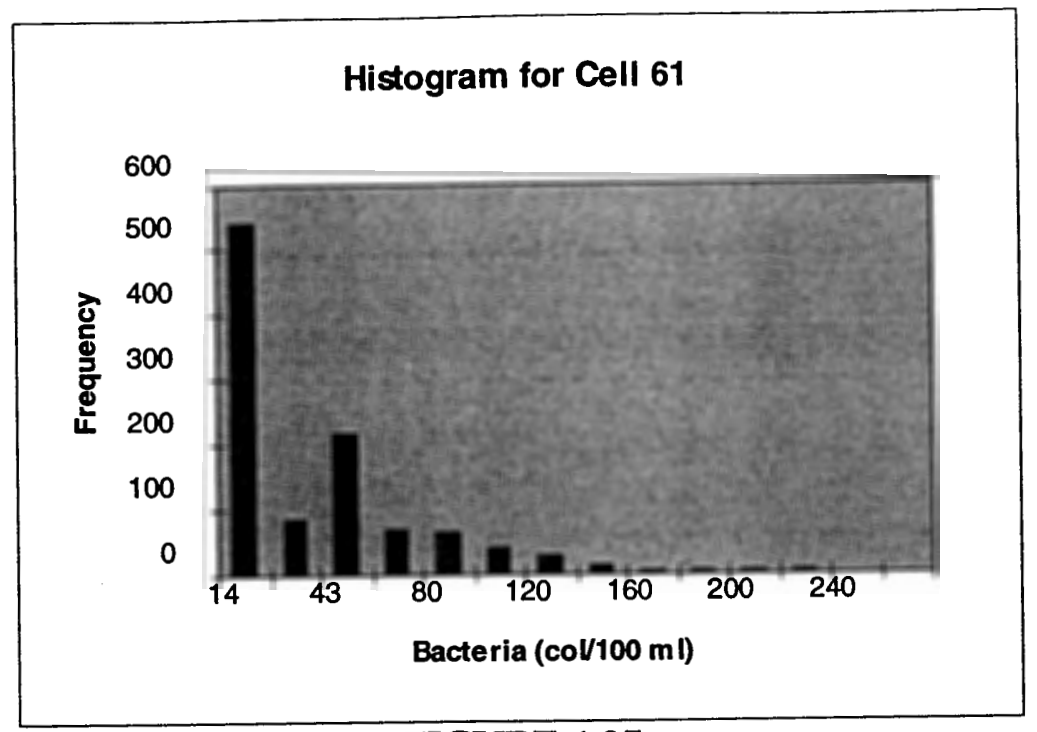

FIGURE 4.95

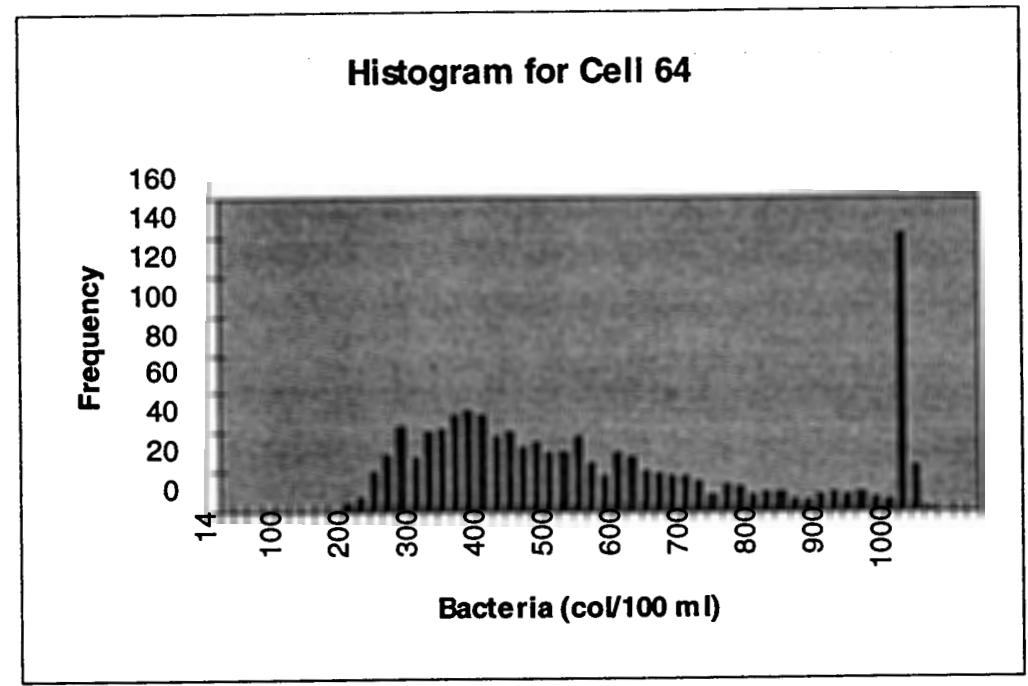

FIGURE 4.96 


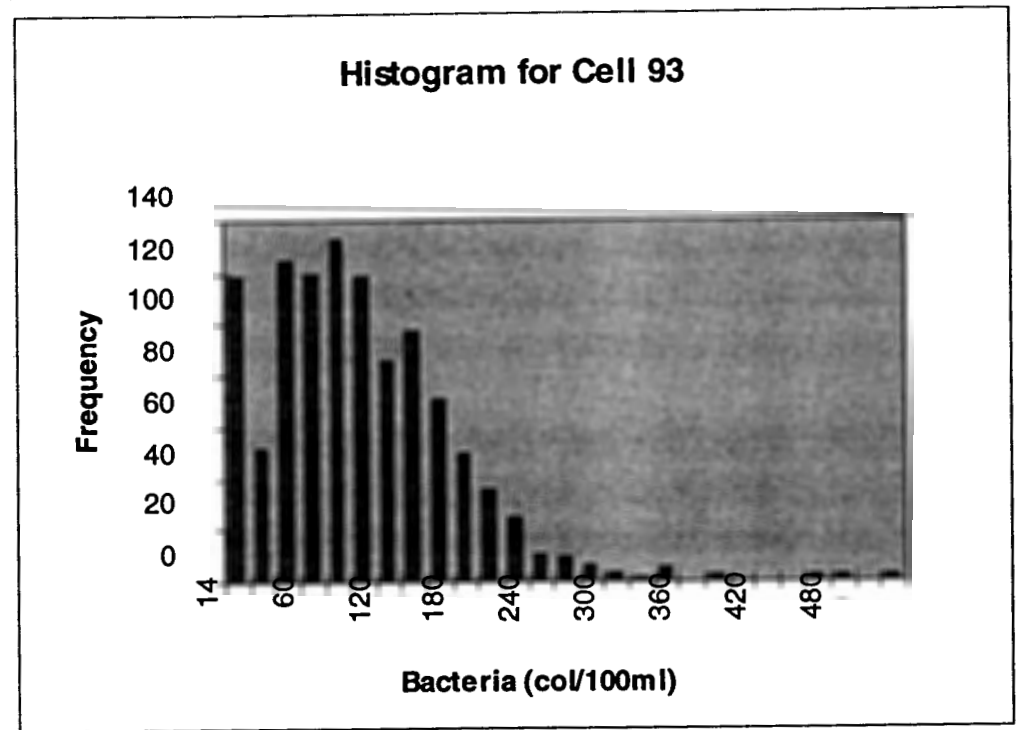

FIGURE 4.97 


\section{CONCLUSION}

The South Slough estuary was calibrated using the water quality model CEQUAL-W2. It was calibrated for the following parameters; water surface elevations, velocity, temperature and total dissolved solids. A management analysis was done analyzing the transport of bacteria and a conservative tracer.

Several weaknesses in the model exist. The predicted water surface elevations are significantly lower than measured water surface elevations. Predicted low peaks of total dissolved solids were higher than actual measured values for part of the simulation period. Temperature and total dissolved solids calibration were based on estimated temperature and concentrations of inflow. Relative humidity measurements were inaccurate and estimated for model input. Inflow calculations based on the Rational Formula were inaccurate and adjusted during calibration.

The strengths of the model include an excellent prediction of velocity, reasonable timing of peaks due to tidal effects, and a comprehensive description of water current behavior. Bacteria transport is closely related to water movements. Therefore, the model is a good tool for understanding transport of bacteria in the South Slough and can be used for further management analysis.

There were data gaps that made calibration difficult. To improve the accuracy of the model additional data collection is required. An important piece of information for this study was rainfall. Installation of a raingage in the South Slough with measurement frequency of at least every hour would improve the accuracy of the input inflow considerably. Modeling of temperature and constituent concentrations carried by the inflow would be more accurate.

An investigation into the difference in measured water surface elevations and the predicted water surface elevations. Possible reasons for the discrepancy include; error in the survey to establish the vertical datum of Hinch Road Bridge, inaccurate water surface elevation readings at Hinch Road Bridge, inaccurate recordings of tidal data at Charleston Harbor, change in bathymetry since measured in 1976, or and obstruction causing water elevations to back up and rise. Recommendations for data collection include the following: A survey of the S4 current meter, new soundings made of the Winchester Creek arm, and at the Hinch Road Bridge gaging station, and a physical inspection for any obstruction that may cause back flow in Winchester Creek arm.

Several points can be made in examining the applicability of the literature review. For the South Slough there is a fairly fast renewal of water, approximately 3 days, and the bacteria die-off rate would have little effect in removing bacteria. 
However, in the Puget Sound Estuary, fecal coliform was bound in the sediment and reproducing due to the organically rich soil from failing drain fields and livestock wastes. Soil conditions could be similar in the South Slough due to the cattle, failed septic systems, and sewage sludge from the landfill. The sediment should be sampled but the final determination as to weather shellfish is fit for human consumption is to test the shellfish themselves. Finally, a direct benefit of pollution abated can be concluded by determining the increase shellfish yield. 


\section{REFERENCES}

Cole, T. and Buchek, E. (1994), Core of Engineers, Revised CE-QUAL-W2, Users Manual, Version 2.0, Waterways Experiments Station, Vicksburg, MS.

Corbitt, Robert A. (1990) Standard Handbook of Environmental Engineering, McGraw-Hill Publishing Company.

Core of Engineers (1990) Draft CE-QUAL-W2, Users Manual, Waterways Experiments Station, Vicksburg, MS.

Core of Engineers (1986) CE-QUAL-W2, Users Manual, Waterways Experiments Station, Vicksburg, MS.

Hoy, Mark (1989) "Researching The Slough", National Audubon Society, March, pp. 99-105.

Hruby, Thomas (1981) "The Shellfish Resource in a Polluted Tidal Inlet," Environmental Conservation, Vol.8, No. 2, Summer, pp. 127-130.

Maidment, David R. (1993) Handbook of Hydrology University of Texas at Austin, McGraw-Hill, Inc.

National Oceanic and Atmospheric Administration, North Bend Airport Raingage data, National Climatic Data Center, Asheville North Carolina.

Oregon Administrative Rules, Chapter 340, Division 41, Department of Environmental Quality, p.17., current as of 6/88

Salomon, Jean Claude, and Pommepuy, Monique (1990) "Mathematical Model of Bacterial Contamination of the Morlaix Estuary (France)", Water Recourse, Vol. 24, No. 8, pp.983-994.

Struck, Philip H. (1988) "The Relationship Between Sediment and Fecal Coliform Levels in a Puget Sound Estuary," Journal of Environmental Health, Vol 50, July/August, No.7.

US Army Corps of Engineers (1981), HEC-1 Flood Hydrograph Package, Users Manual, The Hydrologic Engineering Center, Davis, California.

Wells, Scott and Baird, Brad(1992) "Field Survey Data Summaries, South Slough, Oregon, July 1989- September 1990," Technical Report EWR-007092, Environmental and Water Resources Engineering, Department of Civil 
Engineering, Portland State University, Portland, Oregon.

Wood, P.C. (1979) "Public Health Aspects of Shellfish from Polluted Waters", Biological Indicators of Water Quality edited by A. James and Lilian Evison, CE Department of New Castle Upon Tyne, John Wiley and Sons, pp. 13-9 to 13-13. 


\section{APPENDIX A}

\section{OREGON HEALTH DIVISION}

Sanitation Management Plan

for Commercial Shellfish Harvesting

in Joe Ney and South Slough

Approved May 25, 1988 


\section{OREGON HEALTH DIVISION \\ Sanitation Management Plan \\ for Commercial Shelifish Harvesting \\ In JOE NEY AND SOUTH SLOUGH \\ Approved May 25, 1988}

\section{Classification_of_She1lfish_Growing_Areas_in_Joe_Ney_and_South_Slough}

All growing waters in Joe Ney and South Slough are conditionaliy approved for the harvest of shellfish and shall be operated according to this shellfish management plan, except:

All waters in the Charleston Boat Basin, bounded by the Charleston Bridge on the south and by a line from the Point Adams fish plant due east to the opposite shore on the north, are prohibited and closed to shelifish harvest.

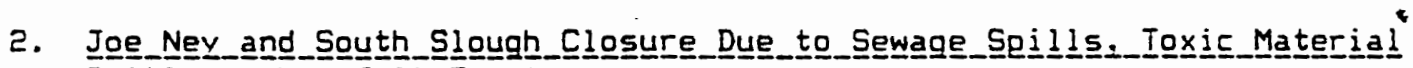
Spilis_or Raingfall Events

The Health Division is the State agency responsible for closing the sloughs to the commercial harvest of shellfish. for the following:

A. Sewage Spill

If there is a sewage spill of such magnitude to affect water quality and shellfish operations, the Division will close the growing area to commercial harvesting of shellfish and provide notice to recreational harvesters.

B. Toxic Material Spill

If there is a toxic material spill of a magnitude to affect water quality and shellfish, the Division will close the growing area to commercial harvesting of shellfish and provide notice to recreational harvesters.

C. Rainfall and Flood Events

1. The Division will evaluate daily rainfall as recorded at the North Bend airpart.

2. When the 5-day rainfall total is 5" or there is more than $1.5^{\prime \prime}$ of rain in any given day, Joe Ney and Sauth Slough shall be closed.

\section{Closure_Notification_Procedure}

The Division shall notify all Joe Ney and South Slough Commercial shellfish growers and harvesters by telephone when the growing area is closed. Written confirmation will be sent to growers and harvesters within 24 hours thereafter. 
4. Meaning_of_Growing_Area_Clogure

All commercial shellfish harvesting shall cease during designated closure periods. Any shellfish harvested and packed. during a closure shall be considered unfit for human food and shall be embargoed according to OAR 333-198-000.

\section{Length_of_Growing_Area_Clogsure}

Sewage or Toxic Materíal Spill

The length of closure is variable and will represent the best estimate of the time needed for water conditions to return to within standards based on such factors as, but not limited to: the volume of sewage or toxic material spilled into the growing area; the location of the 5pil1; the hydrographic characteristics of the growing area at the time of the spill; tides; and rainfall. Water quality. sample results may be used to determine if growing water quality standards are met.

Rainfall Event

When the 5-day rainfall total is 5" or there is more than 1.5 " of rain in any given day, Joe Ney and South Slough shall be closed at least 5 days or until there have been five zonsecutive days below the 5 " rain total and none of the five days with rainfall exceeding $1.5^{\prime \prime}$.

\section{Regeening the Growing Area_Fol lowing Closure}

A. Reopening of growing areas is the responsibility of the Health Division. Length of closure criteria is developed by the Division to guide decision making and is subject to revision.

B. The Division will notify each grower and harvester by telephone when the growing area is reopened. Written confirmation shall be sent to growers and harvesters within 24 hours.

\section{Authority_for_Joe_Ney_and_South_Slough_Management_Plan}

A. ORS 622.180 states that the Division shall have all powers necessary to insure tive saritary production of shell ish, and to make rules necessary to enforce ORS 622. ORS 622.180 and OAR 333-191-000 and 333-191-010 gives the Division the authority to classify and close growing waters to the direct harvest of shellfish when growing water quality exceeds the acceptable standards. This plan sets out a procedure to be followed by the Division and the certified dealers when the growing area water quality exceeds those standards.

B. Any Certified Shellfish Dealer who fails to follow the procedures of this plan shall be considered to have violated OAR 333-191-030 and will be subject to the penalties set forth in ORS 622.992.

C. Failure to comply with the procedures of this plan shall constitute grounds for reappraisal of the plan by the Division and appropriate actions as indicated. 
8. Modifications to the_Joe_Ney and_South_Slough Management_Plan

Modification to this plan may be presented to the South Slough Shellfish Task Force by any party to the plan. Such proposals shall be reviewed by the Task Force and shall be forwarded to the Division Administrator with a recommendation from the Task Force. The Division shall have final authority over such recommendation except contested issues shall be resolved according to ORS 183. 

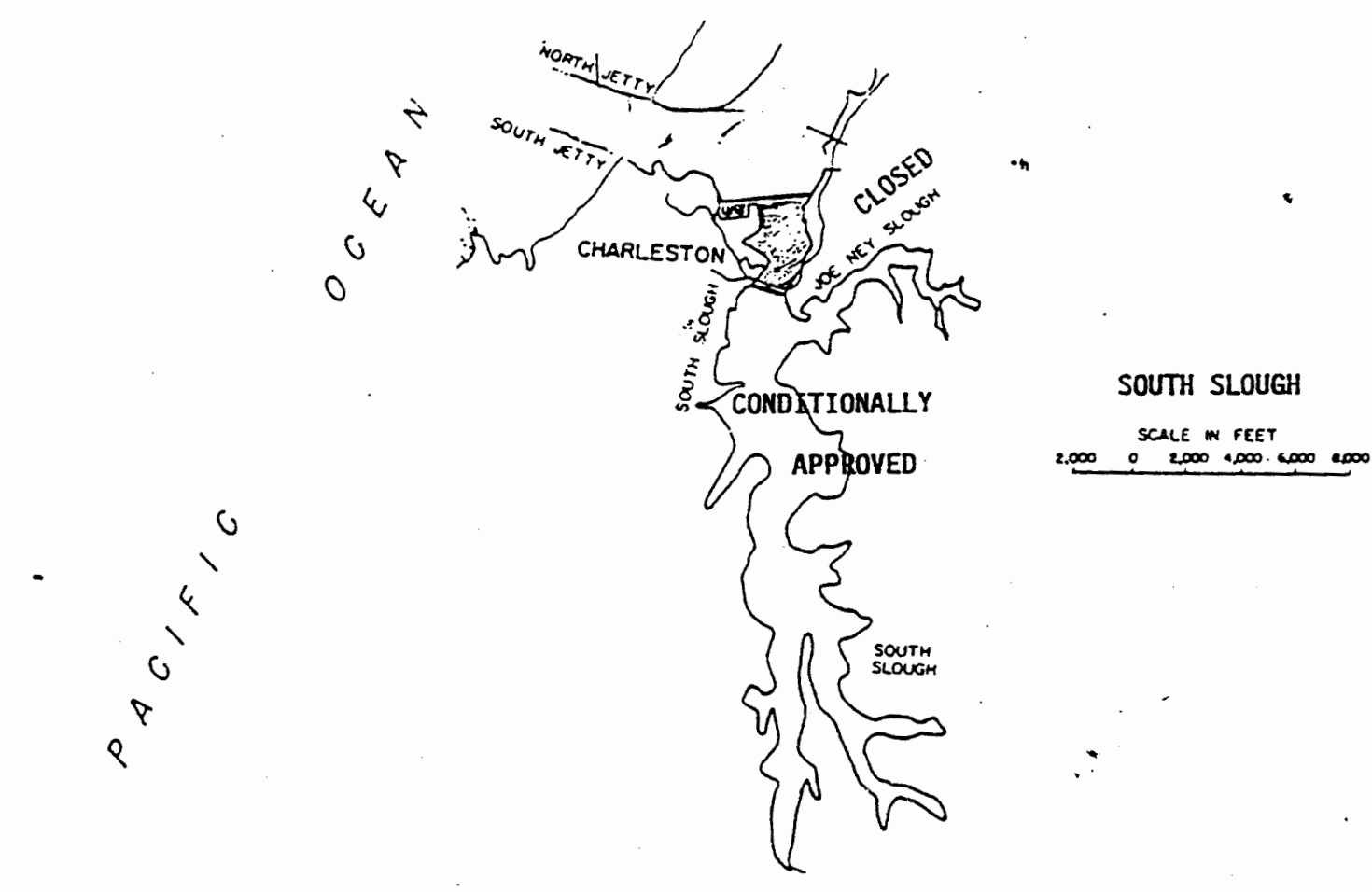


\section{APPENDIX B}

CE-QUAL-W2 INPUT FILES 


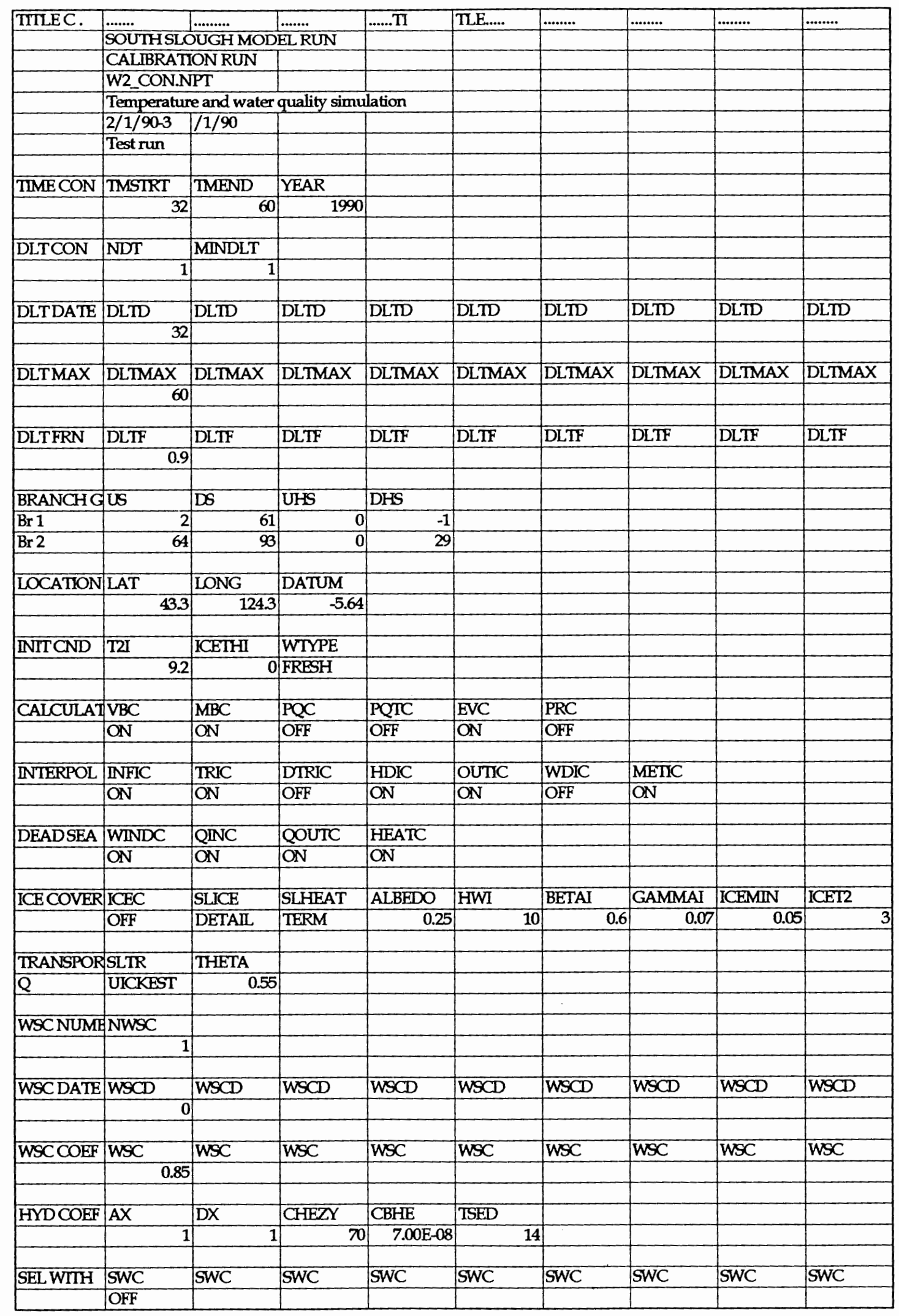




\begin{tabular}{|c|c|c|c|c|c|c|c|c|c|}
\hline & & & & & & & & & \\
\hline NSIRUC & NSTR & NSTR & NSTR & NSTR & NSTR & NSTR & NSTR & NSTR & NSTR \\
\hline & 1 & & & & & & & & \\
\hline KLIMT & KISW & $\overline{\mathrm{KISW}}$ & KISW & KISW & $\overline{\text { KISW }}$ & KISW & KISW & KLSW & KISW \\
\hline $\mathrm{Br} 1$ & 35 & & & & & & & & \\
\hline $\mathrm{Br} 2$ & 35 & & & & & & & & \\
\hline SINK TYPE & SINK & SINK & SINK & SINK & SINK & SINK & SINK & SINK & SINK \\
\hline $\mathrm{Br} 1$ & POINT & & & & & & & & \\
\hline Br 2 & POINT & & & & & & & & \\
\hline & & & & & & & & & \\
\hline ESTRUC & ESTR & ESTR & ESTR & ESTR & ESTR & ESTR & ESTR & ESTR & ESTR \\
\hline $\mathrm{Br} \mathrm{I}$ & 115 & & & & & & & & \\
\hline $\mathrm{Br} 2$ & 115 & & & & & & & & \\
\hline WSTRUC & WSTR & WSTR & WSTR & WSTR & WSTR & WSTR & WSTR & WSTR & WSTR \\
\hline $\mathrm{Br} 1$ & & & & & & & & & \\
\hline Br 2 & & & & & & & & & \\
\hline NOUTLET & NOUT & NOUT & NOUT & NOUT & NOUT & NOUT & NOUT & NOUT & NOUT \\
\hline & $\underline{0}$ & - & & & & & & & \\
\hline OLAYER & KOUT & KOUT & KOUT & KOUT & KOUT & KOUT & KOUT & KOUT & KOUT \\
\hline $\mathrm{Br} 1$ & & & & & & & & & \\
\hline $\mathrm{Br} 2$ & & & & & & & & & \\
\hline & & & & & & & & & \\
\hline NWDRWA & NWD & & & & & & & & \\
\hline & 0 & & & & & & & & \\
\hline WSEGMNT & IWD & IWD & IWD & IWD & IWD & IMD & IWD & IWD & IWD \\
\hline & & & & & & & & & \\
\hline & & & & & & & & & \\
\hline W LAYER & KWD & KWD & KWD & KWD & KWD & $\overline{K W D}$ & KWD & KWD & KWD \\
\hline & & & & & & & & & \\
\hline & & & & & & & & & \\
\hline NTRIBS & NTR & & & & & & & & \\
\hline & 4 & & & & & & & & \\
\hline TRRSEG & $\overline{T R P}$ & & $\pi \mathrm{TR}$ & & & & & & \\
\hline 1NDOSOU & $11 \mathrm{~K}$ & $\begin{array}{ll}111 K \\
-37\end{array}$ & IIR & NKK & IIK & IIR & $11 \mathrm{~K}$ & IIR & IIIK \\
\hline & & & & 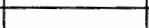 & & & & & \\
\hline DST TRIB & DTRC & DTRC & DIRC & DIRC & DTRC & DTRC & DTRC & DTRC & DIRC \\
\hline & $\mathrm{OFF}$ & 0 & & & & & & & \\
\hline & & & & & & & & & \\
\hline SNAPSHOT & FORM & UPRNC & WPRNC & TPRNC & DTPRNC & SCRC & & & \\
\hline & LONG & ON & ON & ON & ON & $\mathrm{OFF}$ & & & \\
\hline SHRT SEG & IPRSF & IPRSF & IPRSF & IPRSF & IPRSF & IPRSF & IPRSF & PिRF & IPRSF \\
\hline & 2 & 29 & 44 & 55 & 59 & 60 & 61 & 68 & 91 \\
\hline & 94 & 98 & & & & & & & \\
\hline & & & & & & & & & \\
\hline LONGSEG & IPRLF & PRLF & IPRLF & IPRLF & IPRLF & IPRLF & PRRLF & PRLF & IPRLF \\
\hline & 2 & 10 & 29 & 30 & 39 & 50 & 59 & 60 & 61 \\
\hline & 64 & 75 & 85 & 88 & 89 & 90 & 91 & 92 & \\
\hline & & & & & & & & & \\
\hline SNP PRNT & SNPC & NSNP & & & & & & & \\
\hline & ON & 1. & & & & & & & \\
\hline & & & & & & & & & \\
\hline SNP DATE & SNPD & SNPD & SNPD & SNPD & SNPD & SNPD & SNPD & SNPD & SNPD \\
\hline & 32 & 91.7 & \begin{tabular}{|l|}
105.7 \\
\end{tabular} & \begin{tabular}{|r|}
119.7 \\
\end{tabular} & $\begin{array}{r}135.7 \\
\end{array}$ & \begin{tabular}{|l|}
147.7 \\
\end{tabular} & 161.7 & 175.7 & 189.7 \\
\hline & & & & & & & & & \\
\hline
\end{tabular}




\begin{tabular}{|c|c|c|c|c|c|c|c|c|c|}
\hline SNPFREQ & SNPF & SNPF & SNPF & SNPF & SNPF & SNPF & SNPF & SNPF & SNPF \\
\hline & 3 & 100 & 100 & 100 & 100 & 100 & 100 & 100 & 100 \\
\hline PRF PLOT & PRFC & NIRFF & NIPRF & & & & & & \\
\hline & OFF & 21 & 3 & & & & & & \\
\hline & & & & & & & & & \\
\hline PRF DATE & PRFD & PRFD & PRFD & PRFD & PRFD & PRFD & TPRFD & PRFD & PRFD \\
\hline & 77.7 & 91.7 & 105.7 & 119.7 & 135.7 & \begin{tabular}{|l|}
147.7 \\
\end{tabular} & 161.7 & $\quad 175.7$ & $\begin{array}{r}189.7 \\
\end{array}$ \\
\hline & 203.7 & 217.7 & 231.7 & 245.7 & 259.7 & 273.7 & 287.7 & 301.7 & 315.7 \\
\hline & 329.7 & 343.7 & 357.7 & & & & & & \\
\hline & & & & & & & & & \\
\hline PRF FREQ & PRFF & PRFF & PRFF & PRFF & PRFF & PRFF & PRFF & PRFF & PRFF \\
\hline & 100 & 100 & 100 & 100 & 100 & 100 & 100 & 100 & 100 \\
\hline & 100 & 100 & 100 & 100 & 100 & 100 & 100 & 100 & 100 \\
\hline & 100 & 100 & 100 & & & & & & \\
\hline & & & & & & & & & \\
\hline PRFSEG & $\overline{\mathrm{PPRF}}$ & IPRF & IPRF & $\overline{\mathrm{IPRF}}$ & IPRF & IPRF & PRF & IPRF & $\overline{\mathrm{P} R F}$ \\
\hline & 10 & 18 & 26 & & & & & & \\
\hline & & & & & & & & & \\
\hline TSR PLOT & TSRC & NTSR & & & & & & & \\
\hline & OFF & 0 & & & & & & & \\
\hline TSRDATE & TSRD & TSRD & TSRD & TSRD & TSRD & TSRD & TSRD & TSRD & TSRD \\
\hline & & & & & & & & & \\
\hline & & & & & & & & & \\
\hline TSR FREQ & TSRF & TSRF & TSRF & TSRF & TSRF & TSRF & TSRF & TSRF & TSRF \\
\hline & & & & & & & & & \\
\hline VPLPLOT & VPLC & NVPL & & & & & & & \\
\hline & OFF & 0 & & & & & & & \\
\hline VPLDATE & VPLD & VPLD & VPLD & VPID & VPID & VPDD & VPPD & VPLD & VPLD \\
\hline & & & & & & & & & \\
\hline & & & & & & & & & \\
\hline VPLFREQ & VPLF & VPLF & VPLF & VPLF & VPLF & $\overline{\mathrm{VPLF}}$ & VPLF & VPLF & VPLF \\
\hline & & & & & & & & & \\
\hline CPLPLOT & CPLC & NCPL & & & & & & & \\
\hline & OFF & 0 & & & & & & & \\
\hline & & & & & & & & & \\
\hline CPLDATE & CPLD & CPLD & CPLD & CPLD & CPLD & CPLD & CPLD & CPLD & CPLD \\
\hline & 37 & 38 & & & & & & & \\
\hline & & & & & & & & & \\
\hline CPL FREQ & CPLF & CPLF & $\overline{C P L F}$ & CPLF & $\overline{C P L F}$ & $\overline{C P L F}$ & CPLF & CPLF & $C P L F$ \\
\hline & 1 & 150 & & & & & & & \\
\hline & & & & & & & & & \\
\hline RESTART & BSOC & NRSO & RSIC & & & & & & \\
\hline & OFF & & OFF & & & & & & \\
\hline RSO DATE & RSOD & RSOD & RSOD & RSOD & RSOD & RSOD & RSOD & RSOD & RSOD \\
\hline & & & & & & & & & \\
\hline & & & & & & & & & \\
\hline RSOFREQ & RSOF & RSOF & BSOF & RSOF & RSOF & RSOF & RSOF & RSOF & RSOF \\
\hline & & & & & & & & & \\
\hline CSTCOMP & & IDSC & CMn & FPEOTY & & & & & \\
\hline CSTOMP & $\frac{W}{O N}$ & ON & $\frac{S D}{O F F}$ & $\frac{12}{12}$ & & & & & \\
\hline & & & & & & & & & \\
\hline CSTACT & $A C C$ & $A C C$ & $A C C$ & $A C C$ & $A O C$ & $\overline{A C C}$ & $A C C$ & $A C C$ & $\overline{A C C}$ \\
\hline & ON & ON & $\mathrm{ON}$ & $\mathrm{ON}$ & OFF & OFF & OFF & OFF & OFF \\
\hline & OFF & OFF & OFF & OFF & OFF & OFF & OFF & OFF & OFF \\
\hline & OFF & OFF & $\widehat{\mathrm{OFF}}$ & & & & & & \\
\hline
\end{tabular}




\begin{tabular}{|c|c|c|c|c|c|c|c|c|c|}
\hline & & & & & & & & & \\
\hline CSTICON & त्या & कI & ला & C2I & CaI & C2I & CII & C2I & CII \\
\hline & 0 & 2 & 200 & 15000 & 0.7 & 2022 & 1 & 0.1 & 0.001 \\
\hline & 0.002 & 0.14 & 1 & 0 & 11.91 & 31 & 0 & 0 & 0 \\
\hline & 0 & 0.1 & 0 & of & & & & & \\
\hline & & & & & & & & & \\
\hline CSTPRNT & CPRNC & CPRNC & CPRNC & CPRNC & CPRNC & CPRNC & CPRNC & CPRNC & CPRNC \\
\hline & ON & ON & ON & ON & OFF & OFF & $\mathrm{OFF}$ & OFF & OFF \\
\hline & OFF & OFF & OFF & OFF & OFF & OFF & OFF & OFF & OFF \\
\hline & OFF & OFF & OFF & & & & & & \\
\hline & & & & & & & & & \\
\hline CINCON & INACC & INACC & INACC & INACC & INACC & INACC & INACC & INACC & INACC \\
\hline & $\overline{O N}$ & ON & $\overline{O N}$ & $\overline{O N}$ & OFF & OFF & OFF & OFF & OFF \\
\hline & OFF & OFF & OFF & OFF & OFF & OFF & OFF & OFF & OFF \\
\hline & OFF & OFF & OFF & & & & & & \\
\hline CTRCON & TRACC & TRACC & TRACC & TRACC & TRACC & TRACC & TRACC & TRACC & $\overline{\operatorname{RACC}}$ \\
\hline & ON & ON & ON & ON & $\begin{array}{l}\text { OFF } \\
\end{array}$ & OFF & OFF & OFF & OFF \\
\hline & OFF & OFF & OFF & OFF & OFF & OFF & OFF & OFF & OFF \\
\hline & OFF & OFF & OFF & & & & & & \\
\hline & & & & & & & & & \\
\hline CDTCON & DTACC & DTACC & DTACC & DTACC & DTACC & DTACC & DTACC & DTACC & DTACC \\
\hline & OFF & OFF & OFF & OFF & OFF & OFF & OFF & OFF & OFF \\
\hline & OFF & OFF & OFF & OFF & OFF & OFF & OFF & OFF & OFF \\
\hline & OFF & OFF & OFF & & & & & & \\
\hline & & & & & & & & & \\
\hline CPRCON & PRACC & PRACC & PRACC & $\overline{P R A C C}$ & PRACC & PRACC & $\overline{P R A C C}$ & PRACC & $\overline{P R A C C}$ \\
\hline & $\mathrm{OFF}$ & OFF & OFF & OFF & $\mathrm{OFF}$ & $\mathrm{OFF}$ & OFF & OFF & $\mathrm{OFF}$ \\
\hline & OFF & $\mathrm{OFF}$ & OFF & OFF & OFF & OFF & OFF & OFF & OFF \\
\hline & $\widehat{O F F}$ & OFF & $\overline{\mathrm{OFF}}$ & & & & & & \\
\hline & & & & & & & & & \\
\hline EXCOEF & EXH2O & EXINOR & EXORG & BETA & & & & & \\
\hline & \begin{tabular}{|l}
0.45 \\
\end{tabular} & 0.01 & 0.4 & 0.45 & & & & & \\
\hline त्र IF & & COIDK & & & & & & & \\
\hline COLIFUKM & COLQ10 & COLDK & & & $\Gamma-5$ & F & & & \\
\hline & 1.04 & 1.4 & 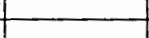 & & & & & & \\
\hline SSOLIDS & SSETL & & & & & & & & \\
\hline & & & & & & & & & \\
\hline & & & & & & & & & \\
\hline ALGAE & AGROW & AMORT & AEXCR & ARESP & ASETL & ASATUR & ALGDET & & \\
\hline & 25 & 可 0.1 & 0.04 & 0.04 & $\quad 0.1$ & 100 & 0.8 & & \\
\hline & & & & & & & & & \\
\hline ALG RATE & AGT1 & AGT2 & AGT3 & AGT4 & AGK1 & AGK2 & AGK3 & AGK4 & \\
\hline & 10 & 30 & 35 & 40 & 0.1 & 0.99 & 0.99 & 0.1 & \\
\hline & & & & & & & & & \\
\hline DBSORG & LABDK & LRFDK & REFDK & & & & & & \\
\hline & \begin{tabular}{|r}
0.3 \\
\end{tabular} & $\quad 0.001$ & 0.01 & & & & & & \\
\hline & & & & & & & & & \\
\hline DETRITUS & DEIDK & DSETL & & & & & & & \\
\hline & 0.08 & $3 \quad 0.3$ & & & & & & & \\
\hline & & & & & & & & & \\
\hline ORGRATE & OMTI & $O M \overline{2}$ & OMKI & OMK2 & & & & & \\
\hline & 4 & 25 & 0.1 & 0.99 & & & & & \\
\hline & & & & & & & & & \\
\hline SEDIMENT & SEDDK & FSOD & & & & & & & \\
\hline & 0.08 & 1 & & & & & & & \\
\hline & & & & & & & & & \\
\hline SDEMAND & SOD & SOD & SOD & SOD & SOD & SOD & SOD & SOD & SOD \\
\hline & $\overline{0}$ & 0 & 0 & 0 & 0 & 0 & 0 & 0 & \\
\hline & 0 & 0 & 0 & 0 & 0 & 0 & 0 & 0 & 0 \\
\hline & 0 & 0 & 0 & 0 & 0 & 0 & 0 & 0 & it \\
\hline
\end{tabular}




\begin{tabular}{|c|c|c|c|c|c|c|c|c|c|}
\hline & 0 & 0 & $\overline{0}$ & 0 & 0 & 0 & 0 & 0 & 0 \\
\hline & 0 & 0 & 0 & 0 & 0 & 0 & 0 & 0 & 0 \\
\hline & 0 & 0 & 0 & 0 & 0 & 0 & 0 & 0 & 0 \\
\hline & 0 & 0 & 0 & 0 & 0 & 0 & 0 & 0 & 0 \\
\hline & 0 & 0 & 0 & 0 & 0 & 0 & 0 & & 0 \\
\hline & 0 & 0 & 0 & 0 & 0 & 0 & 0 & 0 & 0 \\
\hline & 0 & 0 & 0 & 0 & 0 & 0 & 0 & 0 & of \\
\hline & 0 & 0 & 0 & 0 & & & & & \\
\hline & & & & & & & & & \\
\hline$\overline{C B O D}$ & KBOD & TBOD & RBOD & & & & & & . \\
\hline & 0.25 & 1.0147 & 1.85 & & & & & & \\
\hline & & & & & & & & & \\
\hline PHOSPHOF & POAREL & PARTP & AHSP & & & & & & \\
\hline & 0.015 & $\quad 1.2$ & 0.006 & & & & & & \\
\hline & & & & & & & & & \\
\hline AMMONIA & NH3REL & NH3DK & PARTN & A $\overline{H S N}$ & & & & & \\
\hline & 0.05 & 0.1 & 5 & 0.014 & & & & & \\
\hline & & & & & & & & & \\
\hline NH3 RATE & NH3T1 & NH3T2 & $\mathrm{NH} 3 \mathrm{~K} 1$ & NH3K2 & & & & & \\
\hline & 5 & 20 & 0.1 & $\begin{array}{r}0.99 \\
\end{array}$ & & & & & \\
\hline & & & & & & & & & \\
\hline NITRATE & NOBDK & & & & & & & & \\
\hline & 0.05 & & & & & & & & \\
\hline & & & & & & & & & \\
\hline NOB RATE & NOBT1 & NOBT2 & NOBK1 & NOBK2 & & & & & \\
\hline & 5 & 20 & 0.1 & $\begin{array}{r}0.99 \\
\end{array}$ & & & & & \\
\hline & & & & & & & & & \\
\hline SEDCO2 & $\mathrm{CO} 2 \mathrm{REL}$ & & & & & & & & \\
\hline & $\begin{array}{r}0.1 \\
\end{array}$ & & & & & & & & \\
\hline & & & & & & & & & \\
\hline IRON & FEREI & FESETL & & & & 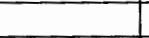 & 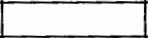 & 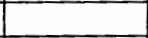 & 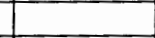 \\
\hline & \begin{tabular}{|r|}
0.5 \\
\end{tabular} & $-\quad$ & & & & & & & \\
\hline & & & & & & & & & \\
\hline STOICHMT & $\overline{\mathrm{O} N \mathrm{NH} 3}$ & O2ORG & O2RESP & O2ALG & BIOP & BION & BIOC & & \\
\hline & 4.57 & 1.4 & 1.4 & 1.4 & 0.011 & 0.08 & 0.45 & & \\
\hline & & & & & & & & & \\
\hline O2LIMT & O2LIM & & & & & & & & \\
\hline & 0 & & & & & & & & \\
\hline & & & & & & & & & \\
\hline BTH FLE & $\ldots \ldots$ & 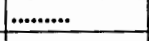 & $\ldots \ldots$ & $\ldots \ldots . . \mathrm{B}$ & THFN.... & $\ldots . . .$. & 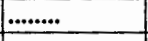 & $\ldots . . . .$. & $\cdots$ \\
\hline & ssbth3.npt & & & & & 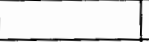 & & 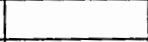 & \\
\hline & & & & & & & & & \\
\hline VPR FILE. & $\ldots \ldots$ & $\ldots . \cdots$ & $\ldots . .$. & $\ldots \ldots . . . \mathrm{V}$ & PRFN.... & $\ldots \ldots$ & $\ldots . . . .$. & $\ldots . . . .$. & $\ldots . . . .$. \\
\hline & vpr.npt & & & & & & & & \\
\hline & & & & & & & & & \\
\hline LPR FILE. & $\ldots . . .$. & $\ldots \ldots$ & $\ldots . . .$. & $\ldots . . . \mathrm{L}$ & PRFN.... & $\ldots . . . .$. & $\ldots \ldots$ & $\ldots \ldots . .$. & 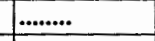 \\
\hline & lpr.npt & & & & & & & & \\
\hline & & & & & & & & & \\
\hline RSI FILE. & $\ldots \ldots$ & $\ldots \ldots$ & 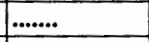 & $\ldots \ldots$ & SIFN.... & $\ldots \ldots$. & $\ldots \ldots . .$. & $\ldots \ldots$ & $\ldots . \cdots$ \\
\hline & rsinpt & & & & & & & - & \\
\hline & & & & & & & & & \\
\hline MET FILE & $\ldots \ldots$ & $\ldots \ldots$ & $\ldots \ldots$ & $\ldots \ldots \mathrm{M}$ & ETFN.... & $\ldots \ldots . .$. & $\ldots . . . .$. & $\ldots \ldots$ & $\ldots . .$. \\
\hline & met190C.dat & & & & & & & & \\
\hline & & & & & & & & & \\
\hline QWD FILE & $\ldots . . . .$. & ............... & $\ldots . .$. & 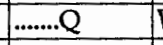 & WDFN.... & $\ldots . . . .$. & $\ldots \ldots$ & $\ldots \ldots$ & $\ldots . . .$. \\
\hline & qwd.npt & & & & & & & & \\
\hline & & & & & & & & & \\
\hline QIN FILE. & $\ldots \ldots$ & $\ldots \ldots . . .$. & $\ldots . .$. & $\cdots \cdots \cdot \bar{Q}$ & INFN.... & $\ldots \ldots . . .$. & $\ldots \ldots . .$. & $\ldots \ldots$ & $\ldots . . .$. \\
\hline $\mathrm{Br} 1 \mathrm{q}$ & tc290. dat & & & & & & & & \\
\hline $\mathrm{Br} 2 \mathrm{q}$ & wc290.dat & & & & & & & $L$ & \\
\hline
\end{tabular}




\begin{tabular}{|c|c|c|c|c|c|c|c|c|c|}
\hline & & & & & & & & & \\
\hline TIN FILE. & $\ldots \ldots$ & $\ldots \ldots$ & $\ldots \ldots$ & $\ldots \mathrm{T}$ & INFN.... & $\ldots . . . .$. & $\ldots . . . . .$. & $\ldots . . . .$. & $\ldots . . . .$. \\
\hline $\mathrm{Br} 1$ & tint.npt & & & & & & & & \\
\hline \multirow{2}{*}{$\mathrm{Br} 2$} & tinw.npt & & & & & & & & \\
\hline & & & & & & & & & \\
\hline CIN FILE. & $\ldots \ldots$. & $\ldots . . . . .$. & $\ldots . . .$. & $\ldots \ldots . .$. & INFN.... & $\ldots \ldots . .$. & $\ldots \ldots . .$. & $\ldots \ldots$ & $\ldots \ldots . . .$. \\
\hline $\mathrm{Br} 1$ & cint.npt & & & & & & & & \\
\hline \multirow[t]{2}{*}{$\mathrm{Br} 2$} & cinw.npt & & & & & & & & \\
\hline & & & & & & & & & \\
\hline QOTFILE & $\ldots . . . .$. & $\ldots \ldots$ & $\ldots . . . .$. & $\ldots . . . Q$ & OTFN.... & $\ldots . . . .$. & $\ldots . . . .$. & 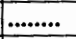 & $\ldots . . . .$. \\
\hline $\mathrm{Br} 1$ & not used & & & & & -1 & & & \\
\hline \multirow[t]{2}{*}{$\mathrm{Br} 2$} & not used & & & & & & & & \\
\hline & & & & & & & & & \\
\hline QTR FIIE & $\ldots \ldots$ & $\ldots \ldots . . . .$. & $\ldots \ldots$ & $\ldots . . . . Q$ & TRFN.... & $\ldots . . . . .$. & $\ldots \ldots$ & $\ldots \ldots . . .$. & $\ldots \ldots$ \\
\hline $\operatorname{Tr} 1$ & gec290.d & at & & & & & & & \\
\hline $\operatorname{Tr} 2$ & gdc290.d & at & & & & & & & \\
\hline Tr 3 & ghc290.d & at & & & & & & & \\
\hline \multirow[t]{2}{*}{$\operatorname{Tr} 4$} & qjc290.d & at & & & & & & & \\
\hline & & & & & & & & & \\
\hline TTR FILE. & $\ldots . . .$. & $\ldots \ldots . . .$. & $\ldots . . .$. & $\ldots . . . \mathrm{T}$ & TRFN.... & $\ldots . . . . .$. & 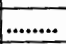 & $\ldots . . . .$. & $\ldots \ldots$ \\
\hline $\operatorname{Tr} 1$ & the.npt & & & & & & - & 5 & \\
\hline $\operatorname{tr} 2$ & ttrd.npt & & & & & & & & \\
\hline $\operatorname{tr} 3$ & ttrh.npt & & & & & & & & \\
\hline \multirow[t]{2}{*}{ tr 4} & ttri.npt & & & & & & & & \\
\hline & & & & & & & & & \\
\hline CTR FIIE. & $\ldots \ldots$ & $\ldots \ldots$ & $\ldots \ldots$ & ........ & TRFN.... & $\ldots \ldots$ & $\cdots \cdots$ & $\ldots \ldots$ & $\ldots$ \\
\hline $\operatorname{tr} 1$ & ctrenpt & & & & & & - & + & {[} \\
\hline tr 2 & ctrdanpt & & & & & & & & \\
\hline $\operatorname{tr} 3$ & ctrh.mpt & & & & & & & & \\
\hline \multirow[t]{2}{*}{$\operatorname{tr} 4$} & ctrjinpt & & & & & & & & 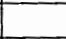 \\
\hline & & & & & & & & & \\
\hline QDT FILE & $\ldots . . .$. & $\ldots \ldots . . . .$. & $\ldots . . . .$. & $\ldots . . . \bar{Q}$ & DTFN.... & $\ldots . . . .$. & $\ldots . . . . .$. & $\ldots . . . . .$. & $\ldots \ldots$ \\
\hline $\mathrm{Br} 1$ & qdt_tr1. & npt-not & used & & & & & & \\
\hline \multirow[t]{2}{*}{$\mathrm{Br} 2$} & not used & & & & & & & & 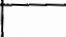 \\
\hline & & & & & & & & & \\
\hline TDT FILE. & $\ldots . . . .$. & $\ldots \ldots$ & $\ldots . .$. & $\ldots . . . \mathrm{T}$ & DTFN.... & $\ldots . . . . .$. & $\ldots . . . .$. & $\ldots . . . .$. & $\ldots . . . .$. \\
\hline $\mathrm{Br} 1$ & tdt_tr1. & npt-not & used & & & & & & \\
\hline \multirow[t]{2}{*}{$\mathrm{Br} 2$} & not used & & & & & & & & \\
\hline & & & & & & & & & te \\
\hline CDT FILE & $\ldots \ldots$ & $\ldots \ldots$ & $\ldots . . .$. & $\ldots . . . \bar{C}$ & DTFN.... & $\ldots . . . . .$. & $\ldots \ldots . .$. & $\ldots \ldots$ & $\ldots \ldots$ \\
\hline $\mathrm{Br} 1$ & cdt_tr1. & $n p t-n o t$ & used & & & & & & \\
\hline \multirow[t]{2}{*}{$\mathrm{Br} 2$} & not used & & & & & & & & \\
\hline & & & & & & & & & \\
\hline PRE FIIE. & $\ldots \ldots$ & $\ldots . . . . . . .$. & $\ldots \ldots$ & .......P & REFN... & $\ldots . . . . .$. & $\ldots . . . .$. & $\ldots . . . . .$. & $\ldots \ldots$ \\
\hline $\mathrm{Br} 1$ & pre_br1. & npt-not & used & & & & & & \\
\hline \multirow[t]{2}{*}{$\mathrm{Br} 2$} & not used & & & & & & & & \\
\hline & & & & & & & & & \\
\hline TPR FILE. & $\ldots \ldots$ & $\ldots . . . . . .$. & $\ldots . . . .$. & $\ldots \ldots . . \mathrm{T}$ & PRFN.... & ............... & $\ldots \ldots$ & 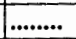 & $\ldots \ldots \ldots$ \\
\hline $\mathrm{Br} 1$ & tpr_br1. & npt-not & used & & & & & & \\
\hline \multirow[t]{2}{*}{ Br2 } & not used & & & & & & & & \\
\hline & & & & & & & & & \\
\hline CPR FILE. & $\ldots \ldots$ & $\ldots \ldots . . .$. & $\ldots . . . .$. & $\ldots . . . \bar{C}$ & PRFN.... & $\ldots . . . .$. & $\ldots . . . .$. & $\ldots \ldots . . .$. & $\ldots \ldots . .$. \\
\hline $\mathrm{Br} 1$ & cpr_br1. & $n p t-n o t$ & used & & & & & & \\
\hline \multirow[t]{2}{*}{$\mathrm{Br} 2$} & not used & & & & & & & & \\
\hline & & & & & & & & & \\
\hline EUH FILE. & $\ldots \ldots$ & $\ldots \ldots \ldots . . .$. & $\ldots \ldots . .$. & ........E & UHFN.... & $\ldots \ldots . .$. & $\ldots \ldots$ & $\ldots . . . . .$. & .......... \\
\hline $\mathrm{Br} 1$ & euh_br1. & npt-not & used & & & & & & \\
\hline \multirow[t]{2}{*}{$\mathrm{Br} 2$} & not used & & & & & & & & \\
\hline & & & & & & & & & \\
\hline TUH FILE & $\ldots$ & 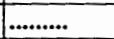 & $\ldots . . .$. & $\ldots \mathrm{T}$ & UHFN.... & .............. & $\ldots \ldots . .$. & .............. & $\ldots \ldots$ \\
\hline $\mathrm{Br} 1$ & tuh_br1. & npt- not & used & & & & & & \\
\hline $\mathrm{Br} 2$ & not used & & & & & & & & \\
\hline
\end{tabular}


CONTROL FILE: W2_CON.NPT

\begin{tabular}{|c|c|c|c|c|c|c|c|c|c|}
\hline & & & & & & & & & \\
\hline CUH FILE & 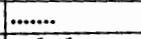 & $\ldots \ldots \ldots$ & $\ldots . . .$. & ......... & UHFN.... & 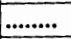 & $\ldots . . . .$. & 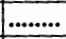 & $\ldots \ldots$ \\
\hline $\mathrm{Br} 1$ & cuh_br1. & npt - not & used & & & & & & \\
\hline \multirow[t]{2}{*}{ br 2} & not used & & & & & & & & \\
\hline & & & & & & & & & \\
\hline EDH FIL. & $\ldots . . . .$. & 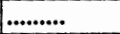 & $\ldots . . .$. & $\ldots . . . . \bar{E}$ & DHFN.... & $\ldots . . . . .$. & $\ldots \ldots . .$. & $\ldots \ldots$ & $\ldots \ldots . .$. \\
\hline $\mathrm{Br} 1$ & ch9o.dat & & & & & & & & \\
\hline \multirow[t]{2}{*}{$\mathrm{Br} 2$} & not used & & & & & & & & \\
\hline & & & & & & & & & 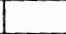 \\
\hline TDHFILE & $\ldots . .$. & $\ldots \ldots$. & $\ldots \ldots$ & $\ldots \ldots . . . \mathrm{T}$ & DHFN.... & .......... & $\ldots \ldots . . . .$. & $\ldots \ldots$ & $\ldots \ldots$ \\
\hline $\mathrm{Br} 1$ & tdh190.npt & & & & & & & & \\
\hline \multirow[t]{2}{*}{$\mathrm{B} \times 2$} & not used & & & & & & & & \\
\hline & & & & & & & & & \\
\hline CDHFILE & $\ldots \ldots$ & $\ldots \ldots \ldots$ & $\ldots \ldots$ & .......C & DHFN.... & $\ldots \ldots$ & $\ldots \ldots$ & $\ldots \ldots$ & $\ldots \ldots$ \\
\hline $\mathrm{Br} 1$ & cdh190.mpt & & & & & 5 & & 5 & \\
\hline \multirow[t]{2}{*}{ Br 2} & not used & & & & & & & & \\
\hline & & & & & & & & & \\
\hline \multirow[t]{2}{*}{ SNP FIIE } & $\ldots . .$. & 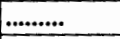 & $\ldots . . .$. & $\ldots . . .5$ & NPFN.... & $\ldots \ldots$ & $\ldots \ldots$ & $\ldots \ldots$ & $\ldots . . . .$. \\
\hline & snp.opt & & & & & & & & \\
\hline & & & & & & & & & . \\
\hline \multirow[t]{2}{*}{ ISR FILE } & $\ldots \ldots$ & $\ldots . . . .$. & $\ldots . . .1$ & $\ldots . \mathrm{T}$ & SRFN... & $\ldots . . . .$. & $\ldots \ldots$ & $\ldots . . .$. & $\ldots . . . .$. \\
\hline & tsr.opt & & & & & & & & \\
\hline & & & & & & & & & + \\
\hline \multirow[t]{2}{*}{ PRF FIIE } & $\ldots \ldots$ & $\ldots \ldots . . .$. & $\ldots \ldots$ & $\bar{P}$ & RFFN... & $\ldots \ldots$ & $\ldots . . . .$. & $\ldots \ldots$ & $\ldots \ldots . . .$. \\
\hline & prf.opt & & & & & & & & \\
\hline & & & & & & & & & \\
\hline \multirow[t]{2}{*}{ VPL FIIE. } & $\ldots \ldots$ & $\ldots \ldots$ & 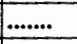 & ....... V & PLFN... & $\ldots . . . .$. & $\ldots \ldots . . .$. & 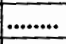 & 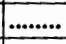 \\
\hline & vplopt & & & & & & & & \\
\hline & & & & & & & & & \\
\hline \multirow[t]{2}{*}{ CPLFIE. } & $\ldots \ldots$ & $\ldots \ldots$ & $\ldots \ldots$ & $\ldots \ldots . . . C$ & PLFN.... & $\ldots \ldots$ & $\ldots \ldots$ & 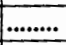 & ............. \\
\hline & cplopt & & & & & & & & \\
\hline & & & & & & & & & \\
\hline \multirow[t]{3}{*}{ SPR FILE. } & $\ldots \ldots$ & $\ldots . . . .$. & $\ldots . . .$. & $\ldots . . . s$ & PRFN.... & 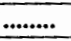 & 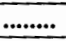 & $\ldots \ldots$ & $\ldots . . .$. \\
\hline & spr.opt & & & & & & & & \\
\hline & & & & & & & & & \\
\hline
\end{tabular}




\begin{tabular}{|c|c|c|c|c|c|c|c|c|c|}
\hline SOUTHS & LOUGHGH & OMETRY II & $\mathrm{P}=94, \mathrm{KM}$ & $\mathrm{P}=14,2$ & BRANCHES & & & & \\
\hline variable & dlo in & bth file & & & & & & & \\
\hline 121.9 & 121.9 & 121.9 & 121.9 & 121.9 & 121.9 & 121.9 & 121.9 & 121.9 & 121.9 \\
\hline 121.9 & 121.9 & 121.9 & 121.9 & 121.9 & 121.9 & 121.9 & 121.9 & 121.9 & 121.9 \\
\hline 121.9 & 121.9 & 121.9 & 121.9 & 121.9 & 121.9 & 121.9 & 121.9 & 121.9 & 121.9 \\
\hline 121.9 & 121.9 & 121.9 & 121.9 & 121.9 & 121.9 & 121.9 & 121.9 & 121.9 & 121.9 \\
\hline 121.9 & 121.9 & $\overline{121.9}$ & 121.9 & 121.9 & 121.9 & 121.9 & 221.9 & 121.9 & 121.9 \\
\hline 121.9 & 121.9 & 121.9 & 121.9 & 121.9 & 121.9 & 121.9 & 121.9 & 121.9 & 121.9 \\
\hline 122 & 122 & 121.9 & 121.9 & 121.9 & 121.9 & 121.9 & 121.9 & 121.9 & 121.9 \\
\hline 121.9 & 121.9 & 121.9 & 121.9 & 121.9 & 121.9 & 121.9 & 121.9 & 121.9 & 121.9 \\
\hline 121.9 & 121.9 & 121.9 & 121.9 & 121.9 & 121.9 & 121.9 & 121.9 & 121.9 & 121.9 \\
\hline 121.9 & 121.9 & 121.9 & 121.9 & 121.9 & 121.9 & 121.9 & 121.9 & 121.9 & 121.9 \\
\hline & & & & & & & & & \\
\hline Surface & location & in m MSL & (not in & z1) & & & & & \\
\hline 0.003 & 0.003 & 0.003 & 0.003 & 0.003 & 0.003 & 0.003 & 0.003 & 0.003 & 0.003 \\
\hline 0.003 & 0.003 & 0.003 & 0.003 & 0.003 & 0.003 & 0.003 & 0.003 & 0.003 & 0.003 \\
\hline 0.003 & 0.003 & 0.000 & 0.003 & 0.000 & 0.003 & 0.003 & 0.003 & 0.003 & 0.003 \\
\hline 0.000 & 0.003 & 0.003 & 0.003 & 0.003 & 0.003 & 0.003 & 0.003 & 0.003 & 0.000 \\
\hline 0.003 & 0.003 & 0.003 & 0.003 & 0.003 & 0.000 & 0.000 & 0.003 & 0.003 & 0.003 \\
\hline 0.000 & 0.003 & 0.003 & 0.003 & 0.000 & 0.003 & 0.003 & 0.003 & 0.003 & 0.000 \\
\hline 0.003 & 0.003 & 0.003 & 0.003 & 0.003 & 0.003 & 0.003 & 0.003 & 0.003 & 0.003 \\
\hline 0.003 & 0.003 & 0.003 & 0.003 & 0.003 & 0.003 & 0.003 & 0.000 & 0.003 & 0.003 \\
\hline 0.003 & 0.003 & 0.003 & 0.003 & 0.003 & 0.003 & 0.003 & 0.003 & 0.003 & 0.003 \\
\hline 0.003 & 0.003 & 0.003 & 0.003 & 0.003 & 0.003 & 0.003 & 0.003 & 0.003 & 0.003 \\
\hline & & & & & & & & & \\
\hline Directio & $n$ cell t & o North $\mathrm{i}$ & n radian & $\mathrm{s}$ & & & & & \\
\hline 5.85 & 5.85 & 5.85 & 5.85 & 5.85 & 5.85 & 5.85 & 5.85 & 5.85 & 5.85 \\
\hline 5.85 & 5.85 & 5.85 & 5.85 & 5.85 & 5.85 & 6.21 & 6.21 & 6.21 & 6.21 \\
\hline 6.21 & 6.21 & 6.21 & 6.21 & 6.21 & 6.45 & 6.45 & 6.45 & 6.45 & 6.45 \\
\hline 6.45 & 0.28 & 0.28 & 0.28 & 0.28 & 0.28 & 0.28 & 0.28 & 0.28 & 0.28 \\
\hline 0.28 & 0.28 & 0.28 & 0.28 & 0.28 & 5.88 & 5.88 & 5.88 & 5.88 & 0.244 \\
\hline 0.244 & 0.244 & 0.244 & 0.244 & 0.244 & 0.244 & 0.244 & 0.244 & 0.244 & 0.244 \\
\hline 0.244 & 0.122 & 0.122 & 0.122 & 0.122 & 0.122 & 0.122 & 0.122 & 0.122 & 0.122 \\
\hline 0.122 & 0.122 & 0.122 & 0.122 & 0.122 & 0.122 & 0.122 & 0.122 & 0.122 & 0.122 \\
\hline 0.122 & 0.122 & 0.122 & 0.122 & 0.122 & 0.122 & 0.122 & 0.122 & 0.122 & 0.122 \\
\hline 0.122 & 0.122 & 0.122 & 0.122 & 0.122 & 0.122 & 0.122 & 0.122 & 0.122 & 0.122 \\
\hline & & & & & & & & & \\
\hline Height & & & & & & & & & \\
\hline 0.61 & 0.61 & 0.61 & 0.61 & 0.61 & 0.61 & 0.61 & 0.61 & 0.61 & 0.61 \\
\hline$\overline{0.61}$ & 0.61 & 0.61 & 0.61 & 0.61 & 0.61 & 0.61 & 0.61 & 0.61 & 0.61 \\
\hline & & & & & & & & & \\
\hline cell 1 & & & & & & & & & \\
\hline$\overline{0}$ & 0 & 0 & 0 & 0 & 0 & 0 & 0 & 0 & 0 \\
\hline 0 & 0 & 0 & 0 & & & & & & \\
\hline & & & & & & & & & \\
\hline 2 & & & & & & & & & \\
\hline$\overline{0}$ & 352.1 & 320.1 & 207.4 & 94.6 & 10.5 & 9.5 & 4 & 3 & 3 \\
\hline 0 & 0 & 0 & 0 & & & & & & \\
\hline & & & & & & & & & \\
\hline 3 & & & & & & & & & \\
\hline 0 & 664.2 & 603.8 & 398.8 & 193.9 & 15.5 & 12 & 4 & 3 & 3 \\
\hline 0 & 0 & 0 & 0 & & & & & & \\
\hline & & & & & & & & & \\
\hline 4 & & & & & & & & & \\
\hline 0 & 25003 & 2273 & 1314.8 & 356.7 & 25.5 & 19 & 4 & 3 & 3 \\
\hline 0 & 0 & 0 & 0 & & & & & & \\
\hline & & & & & & & & & \\
\hline 5 & & & & & & & & & \\
\hline 0 & 8615 & 783.2 & 529.8 & 276.4 & 66.5 & 19 & 4 & 3. & 3 \\
\hline 0 & 0 & 0 & 0 & & & & & & \\
\hline & & & & & & & & & \\
\hline
\end{tabular}




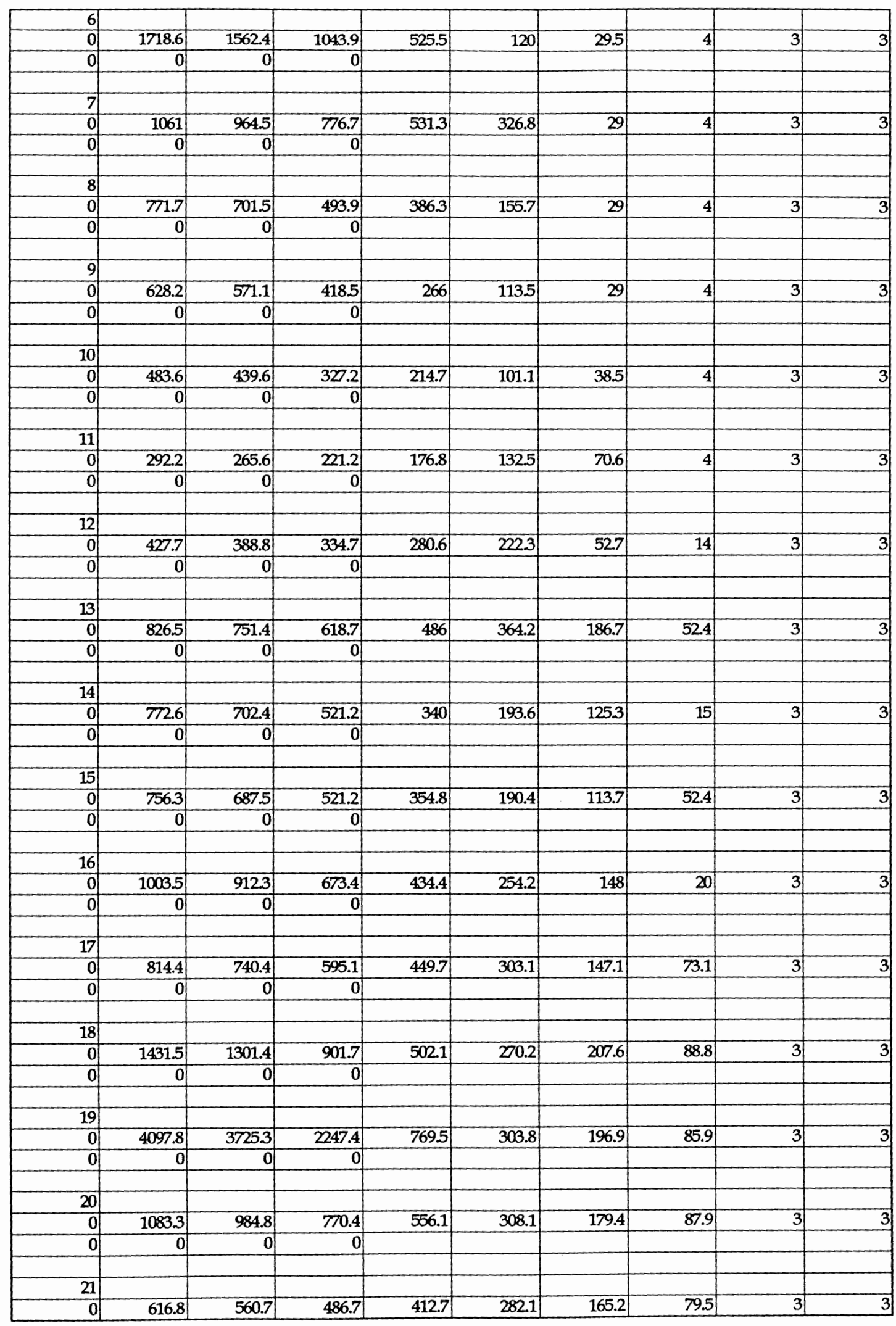




\begin{tabular}{|c|c|c|c|c|c|c|c|c|c|}
\hline 0 & 0 & 0) & 0) & I) & & & & & \\
\hline & & & & & & & & & \\
\hline 22 & & & & & & & & & \\
\hline 0 & 833.5 & 757.7 & 591.9 & 426.1 & 264.4 & 118.8 & 55.1 & 5 & 5 \\
\hline 0 & 0 & 0 & 0 & & & & & & \\
\hline & & & & & & & & & \\
\hline 23 & & & & & & & & & \\
\hline 0 & 921.8 & 838 & 683.5 & 528.9 & 318.9 & 147.9 & 683 & 9 & 9 \\
\hline 0 & 0 & a & 0 & & & & & & \\
\hline & & & & & & & & & \\
\hline 24 & & & & & & & & & \\
\hline 0 & 961 & 873.6 & 718 & 562.3 & 405.1 & 2027 & 1013 & 31.1 & 3 \\
\hline 0 & 0 & 0 & 0) & & & & & & \\
\hline & & & & & & & & & \\
\hline 25 & & & & & & & & & \\
\hline 0 & 2288.4 & 2080.4 & 1704 & 1327.6 & 500.2 & 189.5 & 20 & 9 & 3 \\
\hline 0 & 0 & 0 & 0 & & & & & & \\
\hline & & & & & & & & & \\
\hline 26 & & & & & & & & & \\
\hline 0 & 1313.8 & 1194.4 & 1093.2 & 991.9 & 890.6 & 186.1 & 20 & 8 & 3 \\
\hline 0 & 0 & 0 & 0 & & & & & & \\
\hline & & & & & & & & & \\
\hline 2) & & & & & & & & & \\
\hline 0 & 1527.1 & 13883 & 1243.9 & 10995 & 955.1 & 156.1 & 20 & 9 & 5 \\
\hline 0 & 0 & 0 & 0 & & & & & & \\
\hline & & & & & & & & & \\
\hline 28 & & & & & & & & & \\
\hline 0 & 940.3 & 854.8 & 715.2 & 575.7 & 436.1 & 303.7 & 178.4 & 63.2 & 9 \\
\hline 0 & 0 & 0 & 0 & & & & & & \\
\hline & & & & & & & & & \\
\hline 29 & & & & & & & & & \\
\hline 0 & 818.1 & 743.7 & 624 & 504.3 & 384.6 & 268 & 167.5 & 43.2 & 10 \\
\hline 0 & 0 & 0 & 0 & & & & & & \\
\hline & & & & & & & & & \\
\hline 30 & & & & & & & & & \\
\hline 0 & 889.2 & 808.4 & 598.9 & 389.4 & 245.4 & 170 & 74.3 & 55 & 18 \\
\hline 0 & 0 & 0 & 0 & & & & & & \\
\hline & & & & & & & & & \\
\hline 31 & & & & & & & & & \\
\hline 0 & 883.9 & 803.5 & 660.7 & 517.9 & 375.2 & 284.6 & 150.6 & 95.4 & 41.4 \\
\hline 2 & 0 & 0 & 0 & & & & & & \\
\hline & & & & & & & & & \\
\hline 32 & & & & & & & & & \\
\hline 0 & 794.8 & 7225 & 624.9 & 527.4 & 429.8 & 342.4 & 1427 & 95.1 & 56.8 \\
\hline 11 & 0 & 0 & 0 & & & & & & \\
\hline & & & & & & & & & \\
\hline 33 & & & & & & & & & \\
\hline 0 & 649.9 & 590.8 & 527.5 & 464.2 & 401 & 336.7 & 228.5 & 96.2 & 5 \\
\hline 2 & 0 & 0 & 0 & & & & & & \\
\hline & & & & & & & & & \\
\hline & & & & & & & & & \\
\hline of & 521.4 & 474 & 435.5 & 397 & 358.6 & 320.1 & 181 & 106.2 & 0 \\
\hline a & 0 & 0 & 0 & & & & & & \\
\hline & & & & & & & & & \\
\hline & & & & & & & & & \\
\hline 0 & 2867.9 & 2607.2 & 1741.2 & 875.2 & 336.8 & 290.4 & 133.1 & 76.5 & 20 \\
\hline 0 & 0 & 0 & 0 & & & & & & \\
\hline & & & & & & & & & \\
\hline & & & & & & & & & \\
\hline 0 & 13773 & 12521 & 1108 & 963.8 & 675.7 & 246.4 & 139.4 & 98.1 & 56.8 \\
\hline 5.7 & 0 & 0 & 0 & & & & & & \\
\hline & & & & & & & & & \\
\hline
\end{tabular}


SOUTH SLOUGH BATHEMETRY FILE: SSBTH3.NPT

\begin{tabular}{|c|c|c|c|c|c|c|c|c|c|}
\hline & & & & & & & & & \\
\hline$-\frac{0}{5}$ & 680.9 & 619 & 552.9 & 486.8 & 420.6 & 177 & 138.5 & 109 & 693 \\
\hline & 0 & 0 & 0 & & & & & & \\
\hline & & & & & & & & & \\
\hline 0 & & & & & & & & & \\
\hline 5 & & 000.2 & 661.1 & 488.6 & 365.4 & 338.3 & 146.4 & 103.2 & 423 \\
\hline & & 0 & 0 & & & & & & \\
\hline & & & & & & & & & \\
\hline 0 & 583.3 & 530.3 & 4908 & & & & & & \\
\hline 5 & 0 & 0 & & 401.3 & 411.8 & 364.8 & 278.6 & 126.2 & 79.2 \\
\hline & & & & & & & & & \\
\hline & & & & & & & & & \\
\hline 0 & 638.5 & 580.5 & & & & & & & \\
\hline 14.7 & 0 & 0 & & $4 / 3.2$ & 419.6 & 341.8 & 194.6 & 130.2 & 83.6 \\
\hline & & & 0 & & & & & & \\
\hline & & & & & & & & & \\
\hline 0 & 874 & 794.5 & & & & & & & \\
\hline 0 & 0 & & $0 / 0.1$ & 501.7 & 443 & 331.7 & 192.2 & 144.6 & 90.7 \\
\hline & & & 0 & & & & & & \\
\hline & & & & & & & & & \\
\hline 0 & 1128.9 & 10263 & & & & & & & \\
\hline 0 & 0 & 0 & & 619.6 & 460.2 & 285.3 & 231.8 & 185.8 & 1383 \\
\hline & & & & & & & & & \\
\hline & & & & & & & & $\ldots$ & \\
\hline 0 & 1456.7 & 1324.3 & 1115.9 & 907.4 & 459.9 & 3702 & 2605 & 1836 & 1147 \\
\hline 45.5 & 0 & 0 & 0 & & & & & 100.0 & 14.7 \\
\hline & & & & & & & & & \\
\hline & & & & & & & & & \\
\hline 0 & 1421.2 & 1292 & 1141.1 & 990.2 & 864.1 & 559.8 & 280.2 & 237.5 & 97 \\
\hline 47.9 & 0 & 0 & 0 & & & & & & \\
\hline & & & & & & & & & \\
\hline & & & & & & & & & \\
\hline 0 & 1067.9 & 970.8 & 850.7 & 730.7 & 636.2 & 338.1 & 290.5 & 247 & 78.4 \\
\hline 5 & of & 0 & 0 & & & & & & \\
\hline & & & & & & & & & \\
\hline & & & & & & & & & \\
\hline 0. & 10253 & 932.1 & 831.8 & 731.5 & 630.6 & 348.9 & 266.5 & 203.5 & 136 \\
\hline 이 & 0 & 의 & 0 & & & & & & \\
\hline & & & & & & & & & \\
\hline & & & & & & & & & \\
\hline 0 & 1229.4 & 1117.6 & 960.7 & 803.8 & 633.5 & 367.5 & 262 & 190.5 & 90 \\
\hline 0 & o & 0 & o) & & & & & & \\
\hline & & & & & & & & & \\
\hline & & & & & & & & & \\
\hline 0 & 1383.3 & 1257.5 & 1122.2 & 987 & 845.4 & 407 & 226.5 & 157.8 & 112.2 \\
\hline 74.3 & 26.9 & 0 & 0 & & & & & & \\
\hline & & & & & & & & & \\
\hline & & & & & & & & & \\
\hline 0 & 1056 & 960 & 959.9 & 959.7 & 825.2 & 349.6 & 180.9 & 136.2 & 103.5 \\
\hline 75.1 & 45 & 5 & 0 & & & & & & \\
\hline & & & & & & & & & \\
\hline & & & & & & & & & \\
\hline 0 & 2248.8 & 2044.4 & 1476.9 & 909.4 & 660.8 & 335.6 & 159.2 & 128.9 & 100.2 \\
\hline 76.3 & 525 & 228 & 0 & & & & & & \\
\hline & & & & & & & & & \\
\hline & & & & & & & & & \\
\hline 0 & 978.5 & 889.5 & 835.7 & 781.9 & 638.9 & 346.9 & 305.7 & 1527 & 1113 \\
\hline 81.9 & 51.2 & 5.7 & of & & & & & & \\
\hline & & & & & & & & & \\
\hline & & & & & & & & & \\
\hline 0 & 982.6 & 893.3 & 807.6 & 721.8 & 634 & 534 & 329.1 & 274.9 & 128] \\
\hline
\end{tabular}


SOUTH SLOUGH BATHEMETRY FILE: SSBTH3.NPT

\begin{tabular}{|c|c|c|c|c|c|c|c|c|c|}
\hline 427 & o) & 0 & 0 & I) & & & & & \\
\hline & & & & & & & & & \\
\hline & & & & & & & & & \\
\hline 0 & 920.8 & 837.1 & 769.5 & 701.9 & 6343 & 3283 & 264.4 & 218.5 & 164.7 \\
\hline 34.2 & 0 & 0 & 0 & & & & & & \\
\hline & & & & & & & & & \\
\hline & & & & & & & & & \\
\hline 0 & 905.3 & 823 & 771.3 & 779.6 & 655.9 & 333.9 & 264.9 & 2135 & 162 \\
\hline 36 & 0 & 0 & of & & & & & & \\
\hline & & & & & & & & & \\
\hline & & & & & & & & & \\
\hline 0 & 1408.8 & 1280.7 & 1026 & 771.3 & 687.6 & 392 & 2924 & 216.6 & 161.4 \\
\hline 123.2 & 0 & 0 & 0 & & & & & & \\
\hline & & & & & & & & & \\
\hline & & & & & & & & & \\
\hline 0 & 11823 & 1074.8 & 1004.2 & 933.6 & 868.9 & 411 & 305.1 & 243.7 & 174.1 \\
\hline 1026 & of & 0 & 0 & & & & & & \\
\hline & & & & & & & & & \\
\hline & & & & & & & & & \\
\hline 0 & 1818.5 & 1653.2 & 12143 & 775.4 & 526.2 & 368.1 & 288 & 236.4 & 194.6 \\
\hline 152.5 & 91.8 & 0 & 0 & & & & & & \\
\hline & & & & & & & & & \\
\hline & & & & & & & & & \\
\hline 0 & 1046.2 & 951.1 & 817.1 & 683.1 & 532.2 & 326.7 & 2726 & 2313 & 192.8 \\
\hline 149.6 & 94.1 & 0 & 0 & & & & & & \\
\hline & & & & & & & & & \\
\hline & & & & & & & & & \\
\hline 0 & 939.6 & 854.2 & 734 & 613.8 & 488 & 309.9 & 258.6 & 221.6 & 185.9 \\
\hline 146.3 & 91.1 & 10 & 0 & & & & & & \\
\hline & & & & & & & & & \\
\hline & & & & & & & & & \\
\hline 0 & 841.6 & 765.1 & 649.2 & 533.2 & 417.2 & 253.4 & 220.9 & 192.1 & 163.5 \\
\hline 126.9 & 89.7 & 15 & 0 & & & & & & \\
\hline & & & & & & & & & \\
\hline cell 61 & from har b & bor measu $n$ & rement $\mathrm{t}$ & hrough ti & bridge & & & & \\
\hline 0 & 450 & 345 & 325 & 255 & 200 & 150 & 125 & 103 & 92 \\
\hline 81 & 50 & 20 & 0 & & & & & & \\
\hline & & & & & & & & & \\
\hline & & & & & & & & & \\
\hline 0 & 0 & 0 & a) & 0 & 0 & 0 & 0 & 0 & 0 \\
\hline 0 & 0 & 0 & 0 & & & & & & \\
\hline & & & & & & & & & \\
\hline & & & & & & & & & \\
\hline 0 & 0) & 0 & 0 & 0 & 0 & o. & 0 & 0 & 0 \\
\hline 0 & 0 & 0 & 0 & & & & & & \\
\hline & & & & & & & & & \\
\hline cell 64 & hench ro & ad bridge & & & & & & & \\
\hline 0 & 1423 & 1283 & 86.6 & 44.3 & 18.2 & 5.5 & 4.8 & 3.6 & 3.6 \\
\hline 0 & 0 & 0 & 0 & & & & & & \\
\hline & & & & & & & & & \\
\hline 65 & & & & & & & & & \\
\hline 0 & 261 & 235.8 & 154 & 73 & 18.2 & 5.5 & 4.8 & 3.6 & 3.6 \\
\hline 0 & 0 & 0 & 0 & & & & & & \\
\hline & & & & & & & & & \\
\hline 66 & & & & & & & & & \\
\hline 0 & 307.8 & 298 & 167.8 & 37.7 & 17.5 & 5 & 4 & 3 & 3 \\
\hline 0 & 0 & 0 & 0 & & & & & & \\
\hline & & & & & & & & & \\
\hline 67 & & & & & & & & & \\
\hline 0 & 225.2 & 213.8 & 156.6 & 99.4 & 15.5 & 5 & 4 & 3 & 3 \\
\hline 0 & 0 & 0 & 0 & & & & & & \\
\hline & & 1 & & & & & & & \\
\hline
\end{tabular}


SOUTH SLOUGH BATHEMETRY FILE: SSBTH3.NPT

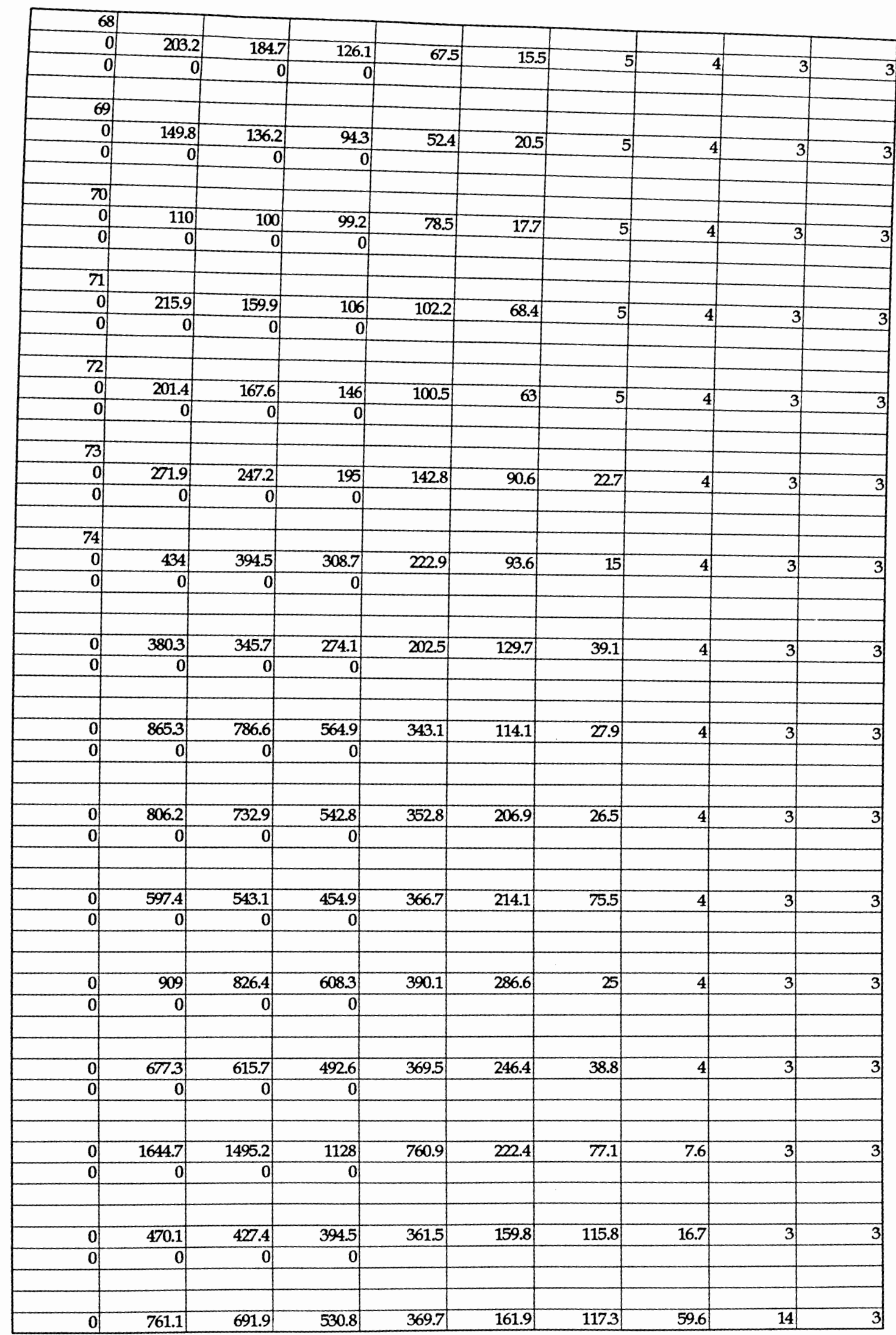


SOUTH SLOUGH BATHEMETRY FILE: SSBTH3.NPT

\begin{tabular}{|c|c|c|c|c|c|c|c|c|}
\hline 0 & 요 & of & 0 & & & & & \\
\hline & & & & & & & & \\
\hline & & & & & & & & \\
\hline 0 & 574.2 & 522 & 418.1 & 314.2 & 2175 & 107.4 & 70.9 & 24.6 \\
\hline 0 & 0 & 0 & 0 & & & & & \\
\hline & & & & & & & & \\
\hline & & & & & & & & \\
\hline 0 & 1208.6 & 1098.7 & 779.7 & 460.7 & 236.7 & 111.7 & 71.7 & 22.4 \\
\hline 0 & 0 & 0 & 0 & & & & & \\
\hline & & & & & & & & \\
\hline & & & & & & & & \\
\hline 0) & 10824 & 984 & 7213 & 458.7 & 270.7 & 99.9 & 39.5 & 16 \\
\hline 0 & 0 & 0 & 0 & & & & & \\
\hline & & & & & & & & \\
\hline & & & & & & & & \\
\hline 0 & 736.9 & 669.9 & 555.2 & 440.4 & 329.2 & 90.7 & 33.7 & 8 \\
\hline 0 & 0 & 0 & 0 & & & & & \\
\hline & & & & & & & & \\
\hline & & & & & & & & \\
\hline 0 & 5395 & 4905 & 431.6 & 372.7 & 167.2 & 103.4 & 45.2 & 5 \\
\hline 0 & 0 & 0 & 0 & & & & & \\
\hline & & & & & & & & \\
\hline & & & & & & & & \\
\hline 0 & 473.6 & 430.5 & 384.9 & 339.4 & 205.2 & 1226 & 58.6 & 5 \\
\hline 0 & 0 & 0 & 0 & & & & & \\
\hline & & & & & & & & \\
\hline & & & & & & & & \\
\hline 0 & 4229.7 & 3845.2 & 2395.8 & 946.5 & 305.6 & 116.7 & 713 & 6 \\
\hline 5 & 0 & 0 & 0 & & & & & \\
\hline & & & & & & & & \\
\hline & & & & & & & & \\
\hline 0 & 714.5 & 6495 & 508.4 & 4673 & 362.9 & 96.2 & 44.2 & 8 \\
\hline 5 & 0 & 0 & 0 & & & & & \\
\hline & & & & & & & & \\
\hline & & & & & & & & \\
\hline 0 & 705.8 & 641.6 & 546.8 & 4521 & 359 & 89.3 & 35 & 10 \\
\hline 5 & 0 & 0 & 0 & & & & & \\
\hline & & & & & & & & \\
\hline & & & & & & & & \\
\hline 0 & 817.9 & 743.5 & 603.2 & 462.8 & 340.8 & 156.1 & 61.3 & 18 \\
\hline 0 & 0 & 0 & 0 & & & & & \\
\hline & & & & & & & & \\
\hline & & & & & & & & \\
\hline 0 & $0]$ & 0 & of & 0 & 0 & 0 & 0 & 0 \\
\hline
\end{tabular}


CONCENTRATION INPUT FILE

\begin{tabular}{|c|c|c|c|c|c|c|c|c|c|c|}
\hline \multicolumn{7}{|c|}{ INPUT DATA FILE SOUTH SLOUGH TALBOT CONC FILE } & & & \multirow[b]{3}{*}{$\mathrm{NH}_{4}$} & \multirow[b]{3}{*}{ NO3 } \\
\hline FILE NAM & $\mathrm{E}: \mathrm{CIN}$ & T.NPT & & & & & & & & \\
\hline JDAY & TRACE & SOLID & FORM D & \$LID BC. & $-L B O D$ & $\mathrm{R} \mathrm{ALG}$ & DETRIT & PO4 & & \\
\hline 32 & 0 & 5 & 1000 & 0 & & & & & & \\
\hline 61 & 0 & 5 & 1000 & 0 & & & & & & \\
\hline
\end{tabular}


TEMPERATURE INPUT FILE

\begin{tabular}{|c|c|c|c|}
\hline$\frac{\text { INPUT DA }}{\text { TEMPERA }}$ & TA FILE SC & UTH SLOUGH TA & OT CREEK \\
\hline JDAY & TIA & & \\
\hline & & & \\
\hline 32 & 7.5 & & \\
\hline 33 & 8.5 & & \\
\hline 35 & 9.5 & & \\
\hline 37.5 & 8.5 & & \\
\hline 41 & 11 & & \\
\hline 43 & 6.5 & & \\
\hline 45 & 8 & & \\
\hline 47 & 7.5 & & \\
\hline 50 & 14 & & \\
\hline 53 & 12.5 & & \\
\hline 55 & 13.5 & & \\
\hline 57 & 15.5 & & \\
\hline 59 & 14.5 & & \\
\hline 61 & 14.5 & & \\
\hline$\bullet$ & & & \\
\hline
\end{tabular}

